\title{
Screening de ligantes para candidatos a receptores de sete domínios transmembrânicos no parasita Plasmodium falciparum
}

Tese apresentada ao Programa de PósGraduação em Biologia da Relação Patógeno-Hospedeiro do Instituto de Ciências Biomédicas da Universidade de São Paulo, para obtenção do Título de Doutor em Ciências 


\section{Screening de ligantes para candidatos a receptores de sete domínios transmembrânicos no parasita Plasmodium falciparum}

Tese apresentada ao Programa de PósGraduação em Biologia da Relação PatógenoHospedeiro do Instituto de Ciências Biomédicas da Universidade de São Paulo, para obtenção do título de Doutor em Ciências

Área de Concentração: Biologia da Relação Patógeno-Hospedeiro

Orientadora: Profa. Dra. Célia Regina da Silva Garcia

Versão original

São Paulo 
DADOS DE CATALOGAÇÃO NA PUBLICAÇÃO (CIP)

Serviço de Biblioteca e Informação Biomédica do

Instituto de Ciências Biomédicas da Universidade de São Paulo

reprodução não autorizada pelo autor

Budu, Alexandre.

Screening de ligantes para candidatos a receptores de sete domínios transmembrânicos no parasita Plasmodium falciparum / Alexandre Budu. -- São Paulo, 2012.

Orientador: Profa. Dra. Célia Regina da Silva Garcia.

Tese (Doutorado) - Universidade de São Paulo. Instituto de Ciências Biomédicas. Departamento de Parasitologia. Área de concentração: Biologia da Relação Patógeno-Hospedeiro. Linha de pesquisa: Biologia Celular e Molecular do Plasmodium.

Versão do título para o inglês: Screening of ligands for seven transmembrane domain receptor candidates in the parasite Plasmodium falciparum.

1. Plasmodium falciparum 2. Receptores de superfície celular 3. Transdução de sinal celular 4. Cálcio I. Garcia, Profa. Dra. Célia Regina da Silva II. Universidade de São Paulo. Instituto de Ciências Biomédicas. Programa de Pós-Graduação em Biologia da Relação Patógeno-Hospedeiro. III. Título. 
Candidato(a):

Título da Tese:
Alexandre Budu.

Screening de ligantes para candidatos a receptores de sete domínios transmembrânicos no parasita Plasmodium falciparum.

Orientador(a):

Profa. Dra. Célia Regina da Silva Garcia.

A Comissão Julgadora dos trabalhos de Defesa da Tese de Doutorado, em sessão pública realizada a considerou

\section{( ) Aprovado(a) \\ ( ) Reprovado(a)}

\begin{tabular}{|c|c|}
\hline Examinador(a): & $\begin{array}{l}\text { Assinatura: } \\
\text { Nome: ........ } \\
\text { Instituição: }\end{array}$ \\
\hline Examinador(a): & $\begin{array}{l}\text { Assinatura: } \\
\text { Nome: ........ } \\
\text { Instituição: }\end{array}$ \\
\hline Examinador(a): & $\begin{array}{l}\text { Assinatura: } \\
\text { Nome: ........ } \\
\text { Instituição: }\end{array}$ \\
\hline Examinador(a): & $\begin{array}{l}\text { Assinatura: } \\
\text { Nome: ....... } \\
\text { Instituição: }\end{array}$ \\
\hline Presidente: & $\begin{array}{l}\text { Assinatura: } \\
\text { Nome: ........ } \\
\text { Instituição: }\end{array}$ \\
\hline
\end{tabular}




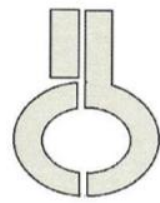

UNIVERSIDADE DE SÃO PAULO

INSTITUTO DE CIÊNCIAS BIOMÉDICAS

Cidade Universitária "Armando de Salles Oliveira"

. . Prol. Lineu Prestes, 2415 - cep. 05508

Av. Prof. Lineu Prestes, 2415 -cep: 05508 : (55)

e-mail: cep@ icb.usp.br

\section{Of.CEPSH. 029.11}

PMAZ/mcgn

São Paulo, 29 de março de 2011.

Prezado Senhor,

Atendendo sua solicitação, a Comissão de Ética em Pesquisas com Seres Humanos do ICB, em sua $113^{\mathrm{a}}$ reunião realizada em 23.03.11, analisou o projeto de sua responsabilidade intitulado: "Transdução de sinal em Plasmodium: screening de ligantes para candidatos a receptores de sete domínios transmembrânicos no parasita".

Informo a V.Sa. que, após análise e discussão, o referido projeto foi considerado isento por não existir manipulação diretamente com seres humanos.

Atenciosamente,

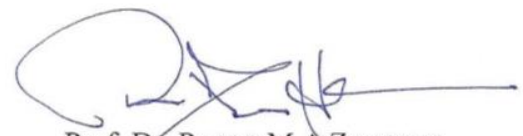

Prof. Dr. PAOLO M.A ZanOTTO

Coordenador da Comissão de Ética em

Pesquisas com Seres Humanos - ICB/USP

Ilmo Sr.

ALEXANDRE BUDU

Departamento de Parasitologia

Instituto de Ciências Biomédicas - USP

Comissão de Ética em Pesquisa com Seres Humanos do Instituto de Ciências Biomédicas / USP Aprovada pela Comissão Nacional de Ética em Pesquisa - CONEP, em 10 de fevereiro de 1998. 


\section{Certificado}

Certificamos que o protocolo registrado sob $\mathrm{n}^{\circ} \mathbf{0 2 7}$ nas fls. 44 do livro 2 para uso de animais em experimentação, sob a responsabilidade de Célia Regina da Silva Garcia Coordenador(a) da Linha de pesquisa "Transdução de sinal em plasmodium: screening de ligantes para candidatos a receptores de sete domínios transmembrânicos no parasita" do qual participou(aram) o(s) alunos Alexandre Budu, está de acordo com os Principios Éticos de Experimentação Animal adotado pelo Colégio Brasileiro de Experimentação Animal (COBEA) e foi aprovado pela COMISSÃO DE ÉTICA EM EXPERIMENTAÇÃO ANIMAL (CEEA) em 27.03.2007.

São Paulo, 28 de março de 2007.

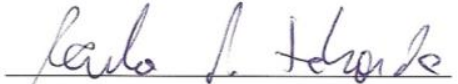

Próf. Dr. Carlos PElleschi TABorda Vice - Coordenador da CEEA - ICB/USP

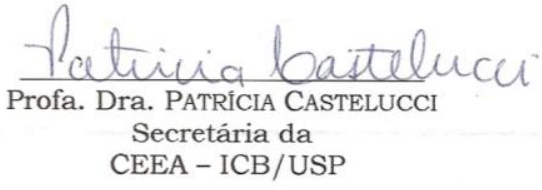


Aos meus pais 


\section{AGRADECIMENTOS}

À minha orientadora, Professora Dra. Célia Regina da Silva Garcia por ter me oferecido a chance de fazer ciência em seu laboratório, pelo incentivo e ajuda nas horas difíceis, pela determinação, orientação e discussões durante os anos de iniciação científica e doutorado. Sua influência me fez crescer muito pessoalmente e cientificamente.

À Dra. Míriam Santos de Moraes, pela colaboração nos experimentos (incontáveis finais de semana em que nos revezávamos para transfectar células). Também pelas discussões e pela amizade durante todos esses anos.

Aos colegas de laboratório com os quais tive o privilégio de conviver durante boa parte desses anos. Provavelmente os melhores colegas que alguém pode ter: Bruno Cunha, Ms. Desiree Schuck, Eduardo Alves, Fernanda Koyama, Lucas Borges, Dra. Laura Cruz, Dra. Myna Nakabashi, Dr. Julio Garcia, Dr. Dario Passos, Dra. Wania Lima, Henrique Borges, Ms. Ramira Yuri, Ms. Rafael Peres, Dr. Abhinay Sharma, Dra Pratibha Gaur, Dra Chiara Currá, Bruna Koresch, Ms. Paloma Sato, Dr. Mauro Azevedo.

Aos ex-colegas de laboratório que me auxiliaram em meus primeiros passos em ciência e tiveram uma paciência infinita comigo: Dr. Flavio Beraldo, Prof. Dr. Marcos Gazarini, Dr. Piero Bagnaresi, Dra. Luciana Madeira.

Ao professor Tullio Pozzan e integrantes do Pozzan lab, que me receberam e trataram muito bem durante o meu estágio no exterior.

A todas as pessoas que participaram na minha formação acadêmica e ajudaram no desenvolvimento dessa tese com sugestões, críticas e reagentes.

À FAPESP, pelas bolsas de iniciação científica e doutorado direto concedidas e pelo profissionalismo e eficiência demonstrados. Ao CNPq por apoiar a pesquisa no laboratório.

Às secretárias Vilma e Silvia do Departamento de Parasitologia pela ajuda na resolução de problemas burocráticos.

Ao Hospital do Servidor Público pelo sangue e plasma cedidos para a cultura de Plasmodium falciparum.

À Tais Octaviani por ter me aguentado no difícil período de finalização da tese. 
Aos meus pais, Nicolae e Despina, pela participação ativa que tiveram na minha educação, pela compreensão e ajuda nas horas difíceis. Aos meus irmãos, Cristian e Elena, pelo companheirismo. A todos os meus amigos pelo apoio. 
“...biologists [had been] in the same situation as astronomers and astrophysicists who were permitted to see the objects of their interest but not to touch them; the cell was as distant from us as the stars and galaxies were for them. More dramatic and frustrating was that we knew that the instrument at our disposal, the microscope...had...reached, irremediably, the theoretical limits of its resolving power."

Albert Claude

"When I threw the extract into the sink, the inside of the sink lit up with a bright blue flash."

Osamu Shimomura

"For a scientist, it is a unique experience to live through a period in which his field of endeavour comes to bloom - to be witness to those rare moments when the dawn of understanding finally descends upon what appeared to be confusion only a while ago - to listen to the sound of darkness crumbling."

George Palade 
“...the writer is delegated to declare and to celebrate man's proven capacity for greatness of heart and spirit — for gallantry in defeat, for courage, compassion and love. In the endless war against weakness and despair, these are the bright rally flags of hope and of emulation."

John Steinbeck 


\section{RESUMO}

Budu A. Screening de ligantes para candidatos a receptores de sete domínios transmembrânicos no parasita Plasmodium falciparum. [tese (Doutorado em Parasitologia)]. São Paulo: Instituto de Ciências Biomédicas, Universidade de São Paulo; 2012.

O parasita da malária Plasmodium falciparum percebe o ambiente em que se encontra, elaborando respostas celulares adequadas, que envolvem secreção de proteínas, crescimento e diferenciação celular. Fatores relacionados com a geração de segundos-mensageiros e proteínas efetoras da sinalização celular estão descritos na literatura. Porém, a função de receptores responsáveis pela percepção de estímulos extracelulares no parasita é um tema pouco explorado. A identificação in silico de receptores de sete domínios transmembrânicos putativos no genoma de $P$. falciparum possibilitou a exploração da função dos mesmos. A tese caracteriza funcionalmente dois receptores, PFSR10 e PFSR25. A expressão proteica dos receptores foi demonstrada em fases eritrocíticas de $P$. falciparum. Os receptores possuem candidatos a parceiros moleculares que executam diversas funções celulares, entre elas invasão do eritrócito, endocitose e exocitose. Os receptores foram transfectados em células de mamíferos e, através de ensaios de dinâmica de cálcio de high-throughput, sugere-se que PFSR10 codifique um receptor que participa na percepção de ATP extracelular e que PFSR25 codifique um sensor de $\mathrm{KCl}$. O trabalho também sugere que $\mathrm{KCl}$ modula cálcio citosólico em $P$. falciparum e que parasitas nocaute para PFSR25 são incapazes de modular cálcio citosólico em resposta a KCl.

Palavras-chave: Plasmodium falciparum. Receptores de superfície celular. Transdução de sinal celular. Cálcio. 


\begin{abstract}
Budu A. Screening of ligands for seven transmembrane domain receptor candidates in the parasite Plasmodium falciparum. [Ph. D. thesis (Parasitology)]. São Paulo: Instituto de Ciências Biomédicas, Universidade de São Paulo; 2012.

The malaria parasite $P$. falciparum perceives its milieu and elaborates adequate intracellular responses, that involve protein secretion, growth and cell differentiation. Factors related to second messengers generation and effectors of cell signaling are described in the literature. However, the function of receptors responsible for stimulus perception remains elusive. The in silico identification of putative seven transmembrane receptors in the Plasmodium falciparum genome allowed the exploration of their function. In the thesis, two putative receptors were characterized, PFSR10 and PFSR25. The proteic expression of the receptors was demonstrated in erythrocytic stages of $P$. falciparum. The receptors have putative interaction partners that participate in cellular functions such as invasion, exocytosis and endocytosis. The receptors were transfected in mammalian cells and, through high-throughput calcium dynamics assays, it is suggested that PFSR10 codes for a receptor that participates in extracellular ATP perception and that PFSR25 codes for a $\mathrm{KCl}$ sensor. It is also suggested that $\mathrm{KCl}$ modulates cytosolic calcium in response to $\mathrm{KCl}$ and that knockout parasites for PFSR25 are incapable of modulating cytosolic calcium in response to $\mathrm{KCl}$.
\end{abstract}

Keywords: Plasmodium falciparum. Cell-surface receptors. Cell signal transduction. Calcium. 


\section{LISTA DE ABREVIATURAS E SIGLAS}

$\left[\mathrm{Ca}^{2+}\right]_{\mathrm{cit}}-$ cálcio citosólico

7-TMR - receptor de sete domínios transmembrânicos

8-Bz-cAMP - 8-benzil-adenosina monofosfato cíclica

A - anel

AAA - ATPases associated with diverse cellular activities

AA-NAT - aralquilamina $\mathrm{N}$-acetiltransferase

AC - adenilato ciclase

$\mathbf{A C} \boldsymbol{\alpha}$ - adenilato ciclase alfa

ADP - adenosina difosfato

AFMK - N-acetil-n-formil-metoqxiquinuramina

AMA-1 - apical membrane antigen 1

AMP - adenosina monofosfato

AMP cíclico - adenosina monofosfato ciclico

ANOVA- analysis of variance

A-T - adenina-timina

ATP - adenosina trifosfato

VA - vacuolo ácido

BAPTA - 1,2-bis(o-aminophenoxy)ethane-N,N,N',N'-tetraacetic acid

BCA - bicinchroninic acid

BFA - brefeldina A

CAM - calmodulina

cAMP - adenosina monofosfato cíclica

cATP - canal de ATP

ECC - entrada capacitativa de cálcio

cDNA - complementary DNA

CDPK - calcium dependent protein kinase

ClpB - caseinolytic peptidase B

CPA - cyclpiazonic acid, ácido ciclopiazônioco

CTP - citidina trifosfato 
DAPI - 4',6-diamidino-2-fenilindol

DMEM - Dulbecco's modified Eagle medium

DNA - deoxyribonucleic acid

EBA175 - erythrocyte binding antigen 175

ECL - electrochemiluminescence

EDTA - ethylenediamine tetraacetic acid

EGTA - ethylene glycol tetraacetic acid

EHD2 - EH- domain containing 2

EI - estoque intracelular

ELISA - enzyme-linked immunosorbent assay

ME - membrana do eritrócito

$\mathbf{R E}$ - retículo endoplasmático

Erid - eritrócito deformado

Erit - eritrócito

ERK - extracellular signal regulated kinase

Esq - esquizonte

F - feminino

FACS - fluorescence-activated cell sorting

FRET - fluorescence resonance energy transfer

GFP - green fluorescent protein

GPI - glycophosphatidylinositol

HBSS - Hank's buffered salt solution

HEK293T - human embryonic kidney 2937

HEK293T-PFSR10 - células HEK293T transfectadas com plasmídeo pcDNA3.1(-)-PFSR10

HEK293T-PFSR10+Ga 15 - células HEK293T cotransfectadas com plasmídeo pcDNA3.1(-)-PFSR10 e plasmídeo pcDNA3.1(-)-G $\alpha_{15}$

HEK293T-PFSR25 - células HEK293T transfectadas

com plasmídeo pcDNA3.1(-)-PFSR25

HEK293T-vazio - células HEK293T transfectadas com plasmídeo pcDNA3.1(-) 
HEK293T-vazio+Ga $\boldsymbol{\alpha}_{15}$ - células HEK293T cotransfectadas

com plasmídeo pcDNA3.1(-) e

plasmídeo pcDNA3.1(-)-G $\alpha_{15}$

HEPES - 4-(2-hydroxyethyl)-1-piperazineethanesulfonic acid

HepG2 - liver hepatocelullar carcinoma cells

HRP - horseradish peroxidase

hsp - heat shock protein

iEri - Eritrócito infectado

IgG - Imunoglobulina $\mathrm{G}$

IP - imunoprecipitação

$\mathbf{I P}_{\mathbf{3}}$ - inositol trifosfato

$\mathbf{I P}_{\mathbf{3}} \mathbf{R}$ - receptor de inositol trifosfato

M - masculino

MAPK - mitogen activated protein kinase

Mel - melatonina

Mer - merozoíto

Mit - mitocôndria

msp1 - merozoite surface protein 1

MT2 - receptor de melatonina 2

$\mathbf{m} / \mathbf{v}$ - massa/volume

MVP - membrana do vacúolo parasitóforo

ORF - open reading frame

Par - parasita

PBS - phosphate buffered saline

$\mathbf{P C R}$ - polymerase chain reaction

FDE - fosfodiesterase

pfsr 10 - Plasmodium falciparum serpentine receptor 10, proteína

pfsr 25 - Plasmodium falciparum serpentine receptor 25, proteína

PFSR1 - Plasmodium falciparum serpentine receptor 1, ORF

PFSR10 - Plasmodium falciparum serpentine receptor 10, ORF

PFSR12 - Plasmodium falciparum serpentine receptor 12 , ORF 
PFSR25 - Plasmodium falciparum serpentine receptor 25, ORF

$\mathbf{P i}$ - inorganic phosphate

PKA - protein kinase A

PKI - protein kinase A inhibitor

PLC - phospholipase C

PLC $\boldsymbol{\beta}$ - phospholipase C beta

MP - membrana plasmática

PMCA - plasma membrane calcium ATPase

PMSF - phenylmethanesulfonylfluoride

Proteína G - proteína ligante de nucleotídeos de guanina

PVDF - polyvinylidene difluoride

PVM - parasitophorous vacuole membrane

Rab - Ras gene from rat brain

RESA - ring-infected erythrocyte surface antigen

RON - rhoptry neck

RNA - ribonucleic acid

RPMI - Roswell Park Memorial Institute

SDS - sodium dodecyl sulfate

SDS-PAGE - sodium dodecyl sulfate polyacrylamide gel electrophoresis

Sec31p - secretory protein 31

Sec63p - secretory protein 63

SERCA - sarcoplasmic reticulum calcium ATPase

SNARE - soluble NSF attachment receptor

SRP - signal recognition particle

TBST - tris buffered saline + tween

TEA - tetraetilamônio

THG - thapsigargin

TRAP - thrombospondin-related adhesive protein

T- trofozoíto

t-SNARE - target SNARE

U73122 - 1-(6-((17ß-3-methoxyestr-1,3,5(10)-trien-17-yl)amino)-hexyl)-1H-pyrrole-2,5-dione 
U73343 - 1-[6-((17ß-3-Methoxyestra-1,3,5(10)-trien-17-yl)amino)hexyl]-2,5-pyrrolidinedione

UD - derivados de uracila

UDP - uridina difosfato

UMP - uridina monofosfato

UTP - uridina trifosfato

UV - ultravioleta

VCP - valosin containing protein

v-SNARE - vesicle SNARE

$\mathbf{v} / \mathbf{v}$ - volume/volume 


\section{LISTA DE FIGURAS}

Figura 1 - Ciclo de vida de Plasmodium. M: masculino, F: feminino. .................................... 27

Figura 2 - Homeostasia de cálcio e via de sinalização de melatonina em Plasmodium................ 31

Figura 3 - Secreção apical de proteínas em esporozoítos de Plasmodium após traversing......... 33

Figura 4 - A diminuição de potássio extracelular gera a secreção apical de micronemas no

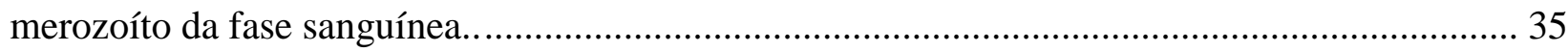

Figura 5 - ATP gera aumento de cálcio em fases intraeritrocíticas do parasita .......................... 37

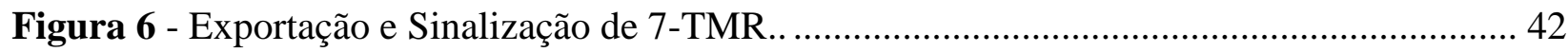

Figura 7 - Deteç̧ão de pfsr10 em P. falciparum através de western blot ........................................ 60

Figura 8 - Localização subcelular de pfsr10 em fases jovens de $P$. falciparum.. ......................... 61

Figura 9 - Localização subcelular de pfsr10 em fases maduras de P. falciparum. ....................... 62

Figura 10 - Controle de especificidade do anticorpo anti-pfsr10 nos ensaios de

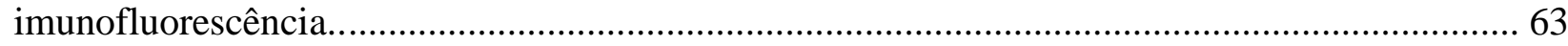

Figura 11 - Efeito da brefeldina A na localização subcelular de pfsr10.. ……................................ 64

Figura 12 - Distribuição de fases e parasitemia após invasão de hemácias por $P$. falciparum em

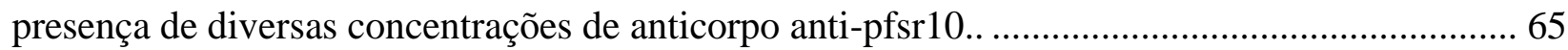

Figura 13 - Proporção de células HEK293T com expressão de pfsr10 identificada...................... 66

Figura 14 - Localização subcelular de pfsr10 em células HEK293T............................................. 67

Figura 15 - Detecção de pfsr10 em células HEK293T através de imunoprecipitação seguida de western blot..

Figura 16 - Dinâmica de cálcio em células HEK293T transfectadas com PFSR10 e estimuladas com nucleotídeos. 71

Figura 17 - Crescimento de células HEK293T-PFSR10+G $\alpha_{15}$ ou HEK293T-vazio+G $\alpha_{15}$.......... 72

Figura 18 - Ensaios de cálcio utilizando aequorina em células 1321N1 transfectadas com

PFSR10 e expressão e localização do receptor em células 1321N1.............................................. 73

Figura 19 - Fosforilação de proteínas de células HEK293T-PFSR10+G $\alpha_{15}$ ou HEK293Tvazio $+\mathrm{G} \alpha_{15}$ 75

Figura 20 - Alteração de fosforilação de proteínas após estímulo com ATP em células HEK293T-PFSR10+G $\alpha_{15}$ ou HEK293T-vazio $+\mathrm{G} \alpha_{15}$ 
Figura 21 - Fosforilação de proteínas de células HEK293T-PFSR10+G $\alpha_{15}$ em relação ao controle transfectado com plasmídeo vazio e $\mathrm{G} \alpha_{15}$.

Figura 22 - Análise da fosforilação de ERK1/2 em células HEK293T-PFSR10 e G $\alpha_{15}$ ou

HEK293T-vazio $+\mathrm{G} \alpha_{15}$ 77

Figura 23 - Imunoprecipitação de proteínas em $P$. falciparum com anticorpo anti-pfsr10. 78

Figura 24 - Imunoprecipitação de proteínas de P. falciparum com anti-pfsr10 após estímulo com ATP. 94

Figura 25 - Detecção de pfsr25 em P. falciparum através de western blot.. 96

Figura 26 - Detecção através de imunofluorescência da expressão de pfsr25 em fases do ciclo eritrocítico de $P$. falciparum. 97

Figura 27 - Localização subcelular de pfsr25 em fase madura de P. falciparum. 98

Figura 28 - Distribuição de fases e parasitemia após invasão de hemácias por $P$. falciparum em presença de diversas concentrações de anticorpo anti-pfsr $25 .$. 99

Figura 29 - Proporção de células HEK293T com expressão de pfsr25 identificada. 100

Figura 30 - Localização subcelular de pfsr25 em células HEK293T. 101

Figura 31 - Detecção de pfsr25 em células HEK293T através de imunoprecipitação seguida de western blot. 102

Figura 32 - Dinâmica de cálcio em células HEK293T-PFSR25 estimuladas com KCl, $\mathrm{NaCl}$ e acetilcolina. rimentos independentes. 105

Figura 33 - Crescimento de células HEK293T-PFSR25 ou HEK293T-vazio. 106

Figura 34 - Aumento de concentração citossólica de cálcio em trofozoítos maduros de $P$. falciparum em resposta a $\mathrm{KCl}$. 107

Figura 35 - Efeito do $\mathrm{KCl}$ na progressão do ciclo de $P$. falciparum ..................................... 108

Figura 36 - Imunoprecipitação de proteínas em $P$. falciparum com anticorpo anti-pfsr25. ...... 110

Figura 37 - Hipóteses sobre a natureza molecular de pfsr10.. .......................................... 130

Figura 38 - Hipóteses para o mecanismo de ativação de pfsr25.. ......................................... 137 


\section{LISTA DE TABELAS}

Tabela 1 - Screening de agonistas para pfsr10 em células HEK293T....................................69

Tabela 2 - Proteínas identificadas exclusivamente na imunoprecipitação com anticorpo antipfsr10, sem peptídeos identificados no controle negativo.

Tabela 3 - Proteínas enriquecidas mais de 3 vezes em relação ao controle negativo na imunoprecipitação utilizando o anticorpo anti-pfsr10

Tabela 4 - Proteínas identificadas em imunoprecipitado com anticorpo anti-pfsr10 em $P$. falciparum.estimulado com ATP

Tabela 5 - Screening de agonistas para pfsr25 em células HEK293T

Tabela 6 - Proteínas identificadas exclusivamente na imunoprecipitação com anticorpo antipfsr25.

Tabela 7 - Proteínas enriquecidas mais que 3 vezes em relação ao controle na imunoprecipitação utilizando o anticorpo anti-pfsr25 


\section{SUMÁRIO}

1 INTRODUÇÃ

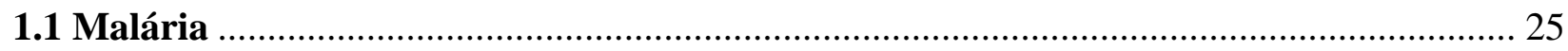

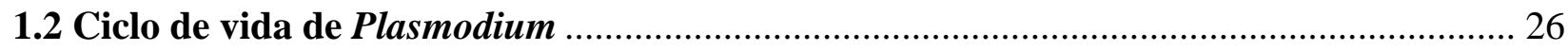

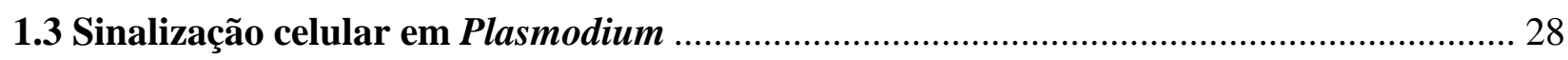

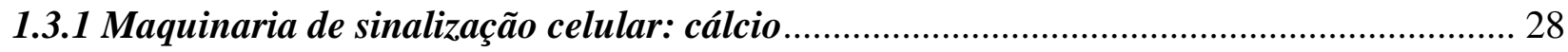

1.3.2 Compostos derivados do triptofano modulam o ciclo de vida de P. falciparum ............... 29

1.3.3 Alguns compostos presentes em altas concentrações intracelulares são sinalizadores em

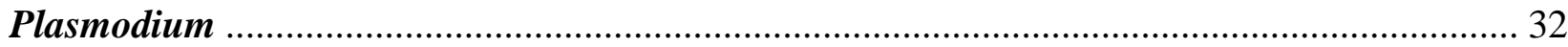

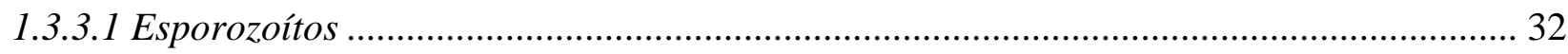

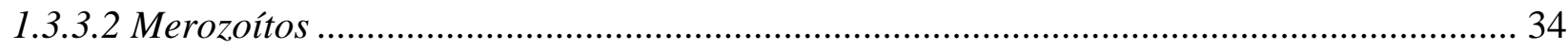

1.4 O Sistema de Sinalização Purinérgico é ubiquitário entre os seres vivos ........................ 37

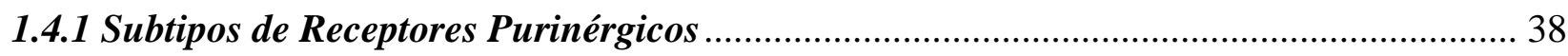

1.5 Receptores de sete domínios transmembrânicos (7-TMR): sinalização, expressão,

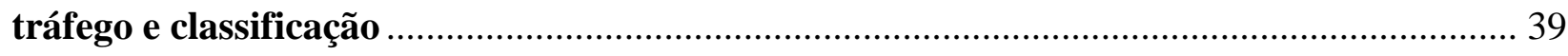

1.5.1 Identificação de 7-TMR no genoma de P. falciparum .................................................. 43

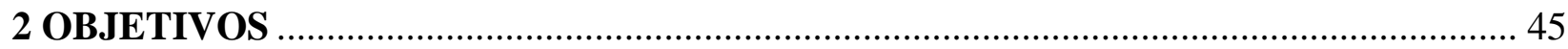

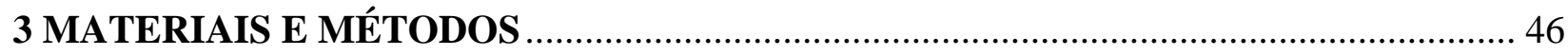

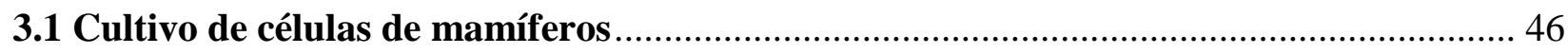

3.2 Cultivo e sincronização de fases intraeritrocíticas de $P$. falciparum ................................. 46

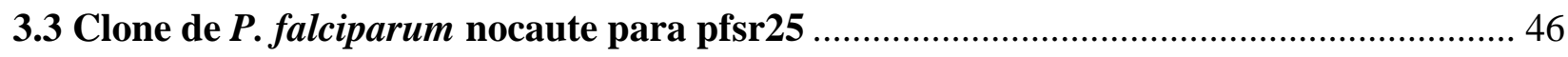

3.4 Plasmídeos para expressar PFSR10 e PFSR25 em células de mamíferos ......................... 46

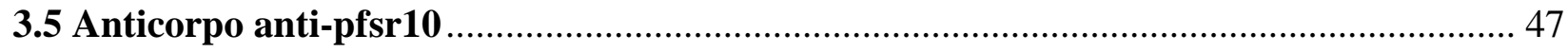

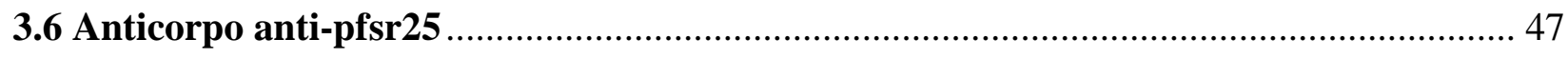

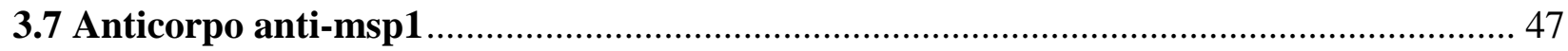

3.8 Deteç̧ão da expressão de pfsr 10, pfsr25 e msp-1 em $P$. falciparum através de

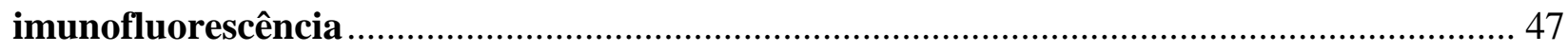

3.9 Lise de hemácias para isolamento de parasitas $P$. falciparum ....................................... 48

3.10 Detecção de pfsr10 e pfsr 25 em estágios intraeritrocíticos de $P$. falciparum através de western blot 
3.11 Co-imunoprecipitação de parceiros moleculares dos receptores putativos pfsr10 e pfsr25 em $P$. falciparum

3.12 Incubação de eritrócitos parasitados por esquizontes de $\boldsymbol{P}$. falciparum com anticorpo anti-pfsr10 ou anti-pfsr25 e contagem de parasitemia.................................................. 50

3.13 Ensaios de dinâmica de cálcio em $P$. falciparum ................................................... 51

3.14 Contagem de fases intraeritrocíticas e parasitemia de parasitas $P$. falciparum

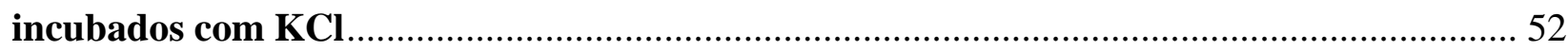

3.15 Transfecção e ensaios de dinâmica de cálcio em células 1321N1 ............................... 52

3.16 Transfecção de células HEK293T ...................................................................... 53

3.17 Ensaios de dinâmica de cálcio em células HEK293T transfectadas com pcDNA3.1 -

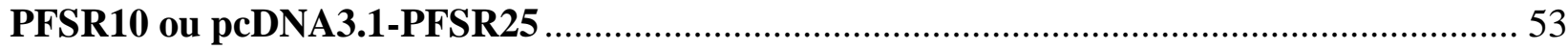

3.18 Crescimento de células HEK293T ...................................................................... 54

3.19 Experimentos de fosforilação em células HEK 293T transfectadas com pcDNA3.1(-)PFSR10 e pcDNA3.1(-)-G $\alpha_{15}$

3.20 Detecção da expressão de pfsr10 e pfsr25 em linhagens de células de mamíferos transfectadas através de imunofluorescência

3.21 Detecção da expressão de pfsr10 e pfsr25 em células HEK293T transfectadas através de imunoprecipitação seguida de western blot ............................................................. 57

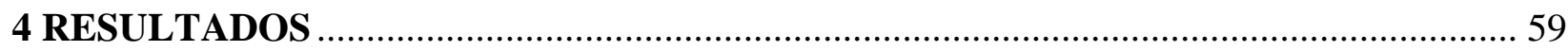

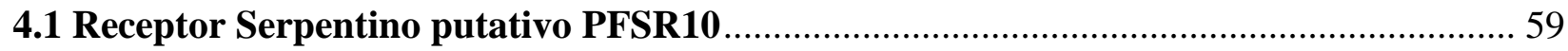

4.1.1 Expressão proteica e localização de pfsr10 em fases sanguíneas de Plasmodium falciparum: o receptor putativo é expresso em todas as fases do ciclo intraeritrocítico e transita pela via de exportação proteica.

4.1.2 Anticorpo anti-pfsr10 não altera significativamente invasão e desenvolvimento intraeritrocítico de P. falciparum.

4.1.3 Em sistema heterólogo, pfsr10 é identificada como proteína de aproximadamente $80 \mathrm{kDa}$ e colocaliza parcialmente com a membrana plasmática

4.1.4 Screening de agonistas para pfsr10: alguns nucleotídeos promovem maior aumento de $\left[\mathrm{Ca}^{2+}\right]_{\text {cit }}$ em células HEK293T-PFSR10+G ${ }_{\alpha 15}$

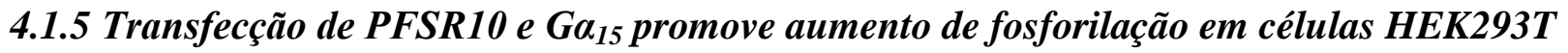

4.1.6 Proteínas candidatas a interagir com pfsr10 desempenham diversas funções celulares . 78

4.1.6.1 Proteínas relacionadas a tradução, via exocítica e via endocítica.................................. 91

4.1.6.2 Proteína relacionada à ubiquitinação.......................................................................... 92 
4.2.1 Expressão proteica e localização de pfsr25 em fases sanguíneas de Plasmodium falciparum: o receptor putativo é mais expresso nas fases de trofozoíto e esquizonte do ciclo intraeritrocítico .

4.2.2 Anticorpo anti-pfsr25 não altera invasão de hemácias por P. falciparum

4.2.3 Em sistema heterólogo, pfsr25 é identificada como proteína de aproximadamente 40 kDa e colocaliza parcialmente com a membrana plasmática

4.2.4 Screening de agonistas para o candidato a receptor serpentino pfsr25: $\mathrm{KCl}$ promove maior aumento de [Ca2+]cit em células HEK293T-PFSR25

4.2.5 $\mathrm{KCl}$ provoca aumento de $\left[\mathrm{Ca}^{2+}\right]_{c i t}$ dependente de pfsr25, em trofozoítos maduros de $\mathrm{P}$.

falciparum e modula a ruptura de eritrócitos infectados por esses estágios

4.2.6. Proteínas candidatas a interagir com pfsr 25 desempenham diversas funções celulares

4.2.6.1 Proteínas relacionadas a tradução, via exocítica e via endocítica.

4.2.6.2 Proteínas relacionadas à ubiquitinação

4.2.6.3 Proteínas relacionadas à saída de eritrócitos, invasão e estabelecimento na célula hospedeira....

4.2.6.4 Chaperonas.

4.2.6.5 Outras proteínas.....

5 DISCUSSÃO

5.1 Receptor serpentino putativo PFSR10

5.1.1 Expressão e localização de pfsr10 em fases sanguíneas de P. falciparum

5.1.2 Anticorpo anti-pfsr10: invasão e desenvolvimento intraeritrocítico de P. falciparum ... 126

5.1.3 Expressão de pfsr10 em sistema heterólogo

5.1.4 Ensaios de $\left[\mathrm{Ca}^{2+}\right]_{\text {cit }}$ com nucleotídeos em células HEK293T-PFSR10+Ga 15 .

5.1.6 Imunoprecipitação de candidatos a parceiros moleculares de pfsr10 em P. falciparum 131 5.1.7 Imunoprecipitação de parceiros moleculares de pfsr10 em P. falciparum após estímulo com ATP. 
5.2 Receptor serpentino putativo PFSR25

5.2.1 Expressão de pfsr25 em P. falciparum

5.2.2 Anticorpo anti-pfsr25 e invasão de hemácias por P. falciparum

5.2.3 Expressão de pfsr25 em sistema heterólogo

5.2.4 Ensaios de cálcio em células HEK293T transfectadas com PFSR25 e estimuladas com

$\mathrm{KCl}$ 136

5.2.5 Sinalização de $\mathrm{KCl}$ em parasitas intraeritrocíticos 138

5.2.6 Imunoprecipitação de candidatos a parceiros moleculares de pfsr25 em P. falciparum 139

6 CONCLUSÕES.

REFERÊNCIAS 142

ANEXO - Artigos publicados no período do doutorado 153 


\section{INTRODUÇÃO}

\subsection{Malária}

A malária é uma doença que afeta a humanidade há milênios. Espécies do parasita da malária são mais antigas que o próprio ser humano, existindo há pelo menos 150 milhões de anos e infectando diversas espécies de vertebrados (revisado em Carter e Mendis 2002). O protozoário ancestral que deu origem ao parasita da malária provavelmente possuía cloroplasto, reprodução sexuada obrigatória e habitava o intestino de invertebrados aquáticos (revisado em Carter e Mendis, 2002). A aquisição da reprodução assexuada (esquizogonia) no interior de células representou um aumento no potencial proliferativo dos parasitas, que provavelmente passaram a infectar larvas de dípteros, e, adaptando-se ao hábito alimentar desses insetos, passaram a ter também um hospedeiro vertebrado. Em humanos, existem quatro espécies de Plasmodium que provocam malária: $P$. falciparum, $P$. ovale, $P$. malariae e $P$. vivax. É interessante que $P$. falciparum, o parasita responsável pelas formas mais graves da doença é evolutivamente mais próximo de $P$. reichenowi, um parasita de chimpanzés, e de parasitas de aves do que dos outros parasitas humanos. Isso indica que a separação do ancestral de $P$. falciparum e parasitas que infectam aves dos demais parasitas que infectam mamíferos foi um evento antigo (revisado em Carter e Mendis, 2002).

Atualmente, as espécies humanas de Plasmodium mais prevalentes no mundo são $P$.

falciparum (que afeta em especial a África subsaariana) e P. vivax (que afeta Ásia, América Central e América do Sul), (revisado em Carter e Mendis, 2002).

Os números da doença divulgados pela Organização Mundial da Saúde encontram-se muito provavelmente subestimados, pois são obtidos a partir de relatórios passivos dos países afetados. Snow et al. (2005) estima que a doença afeta cerca de 500 milhões de pessoas no mundo. A mortalidade chega a 3 milhões de seres humanos anualmente, o maior número entre doenças parasitárias (Snow et al., 2005).

Durante a história e atualmente, a malária tem sido uma grande barreira para o desenvolvimento humano. A doença é capaz de dificultar ou impossibilitar grandes projetos econômicos (revisado em Carter e Mendis, 2002). Apesar de a área de ocorrência da malária ter sido confinada às regiões tropicais do globo após políticas de contenção, o número de pessoas que vivem em áreas de risco tem crescido e se encontra em torno de 3 bilhões, e há a expectativa de que continue crescendo (revisado em Guinovart et al., 2006). Há estudos 
evidenciando a relação causal existente entre malária e pobreza (revisado em Worrall et al., 2005). A associação entre áreas pobres do globo e malária é um fato que não ajuda a aumentar o interesse na criação de fármacos para o combate à doença (Trouiller et al., 2002). Além disso, a procura de tratamento especializado em países pobres é pequena, observando-se mais a automedicação (revisado em Worrall et al., 2005). Um fator agravante é o surgimento de cepas de parasitas resistentes às drogas comumente usadas (revisado em Petersen et al., 2011). Apesar do aumento dos recursos para combate da malária para 1 bilhão de dólares em 2008 e do uso de várias estratégias (antimaláricos, mosquiteiros e inseticidas) faz-se necessário um monitoramento para verificar os progressos no controle da doença e onde os esforços devem ser focados (Grabowsky, 2008).

Uma vacina, que oferece $50 \%$ de proteção à infecção, se encontra em fase final de teste na África (Agnandji et al., 2011). Essa é a primeira vacina que oferece proteção em testes em campo, o que justifica otimismo para futuras formulações (Agnandji et al., 2011).

O melhor entendimento da biologia do parasita é um passo essencial para a identificação de alvos para o desenvolvimento de drogas e vacinas eficazes no combate à doença.

\subsection{Ciclo de vida de Plasmodium}

O parasita eucarioto unicelular causador da malária, do gênero Plasmodium, tem um ciclo de vida complexo (Figura 1). O mosquito infectado pica o hospedeiro injetando esporozoítos na derme através da saliva. Os esporozoítos, através da circulação sanguínea, invadem hepatócitos e sofrem divisões mitóticas, formando merozoítos, que entram na corrente sanguínea e invadem hemácias, formando a fase de anel. $\mathrm{O}$ anel se desenvolve em trofozoíto e este, em sua fase madura, começa a sofrer divisões mitóticas, dando origem ao esquizonte. Ao final da esquizogonia há o rompimento da hemácia, liberando merozoítos na corrente sanguínea. Esses reinvadem hemácias, repetindo o ciclo (revisado em Bannister e Mitchell, 2003). O ciclo eritrocítico é o responsável pelos sintomas clínicos da doença (febres recorrentes concomitantes com a liberação de merozoítos na corrente sanguínea). Alguns dos merozoítos que invadem hemácias sofrem diferenciação em gametócitos feminino ou masculino. 
Figura 1 - Ciclo de vida de Plasmodium. M: masculino, F: feminino.

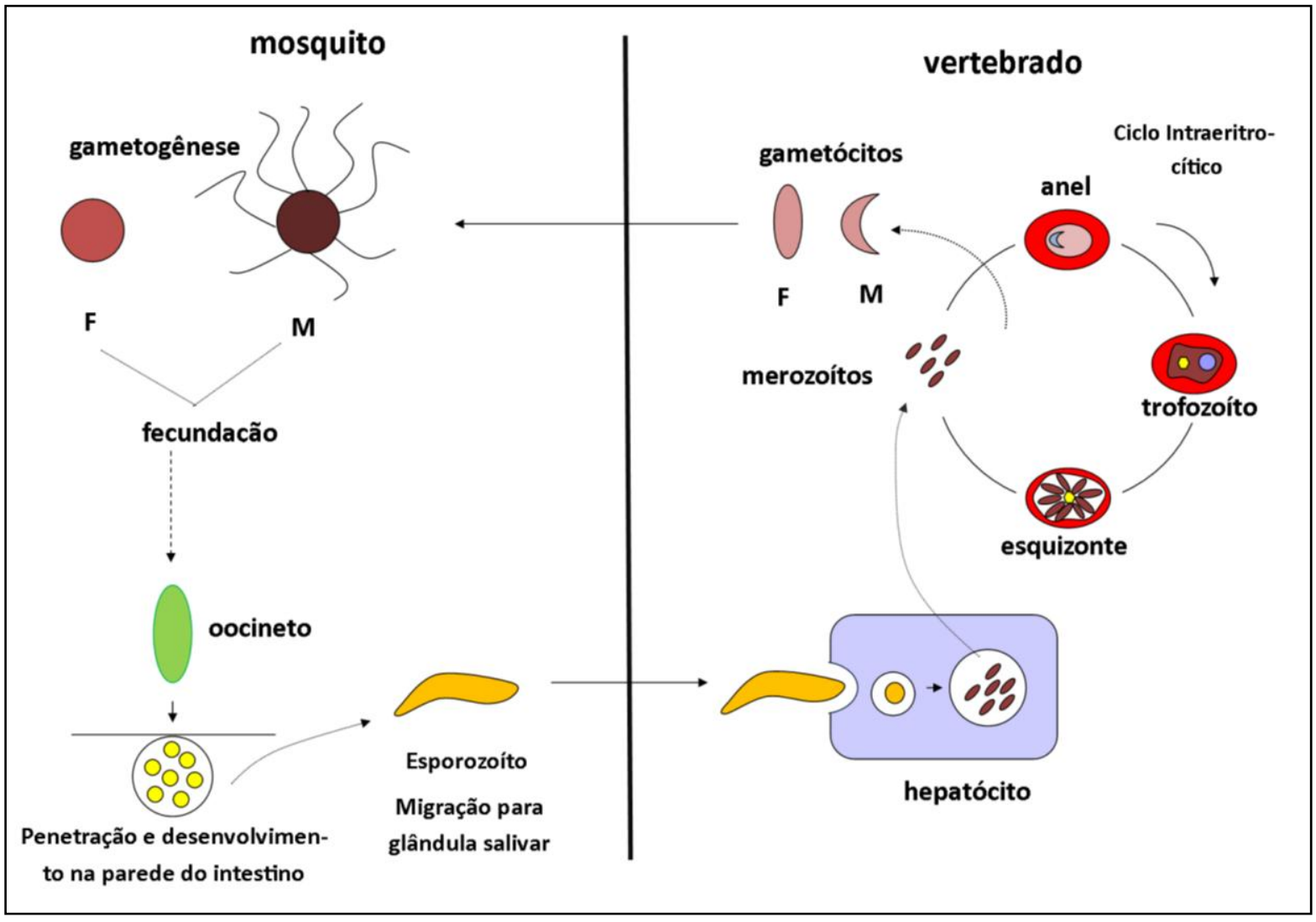

Fonte: Adaptado de Bannister e Mitchell (2003).

Os gametócitos, ingeridos pelo mosquito durante a picada, se diferenciam em gametas e ocorre a fertilização, dando origem a uma forma móvel, o oocineto. $\mathrm{O}$ oocineto instala-se no epitélio do intestino médio do Anopheles e sofre divisão reducional seguida de mitoses, dando origem a esporozoítos, que migram para as glândulas salivares do inseto (revisado em Bannister e Mitchell, 2003).

Recentemente, aspectos interessantes do ciclo de vida do parasita foram reportados. Amino et al. (2006), utilizando esporozoítos expressando GFP e acompanhamento ao vivo e in vivo do parasita, demonstraram que além da invasão de vasos sanguíneos do hospedeiro intermediário, os esporozoítos também adentram vasos linfáticos e sofrem diferenciação parcial em nódulos, não alcançando, porém, a circulação sanguínea através do duto torácico. Esse aspecto poderia influir no reconhecimento do parasita pelo sistema imune. Sturm et al. (2006) demonstraram que o merozoíto hepático apresenta uma solução interessante para escapar às células de Kuppfer que patrulham os sinusóides do fígado: a liberação na corrente sanguínea de vários merozoítos, envoltos por membrana proveniente do hepatócito (merossomo) que não expõe resíduos de fosfatidilserina, sinal para a fagocitose, na 
membrana. Apesar da apoptose do hepatócito, evidenciada pela dispersão do citocromo c no citosol, pela condensação do núcleo celular e pela mudança da morfologia das mitocôndrias, os autores sugerem que a exposição de fosfatidilserina é evitada através da captação do cálcio liberado das organelas do hepatócito em apoptose pelos merozoítos. Caso um ionóforo de cálcio seja adicionado, ocorre exposição de fosfatidilserina na membrana do hepatócito (Sturm et al., 2006). Além dos exemplos acima, o parasita desenvolveu outras estratégias, dentre as quais se podem mencionar a criação de condições favoráveis para desenvolvimento no interior das hemácias (Desai et al., 1993; Gazarini et al., 2003) e indução da adesão da célula hospedeira a vasos sanguíneos (revisado em Rug et al., 2006). As diversas particularidades do ciclo de vida do parasita demonstram a sua versatilidade, com consequente bem-sucedido desenvolvimento em seus hospedeiros.

\subsection{Sinalização celular em Plasmodium}

Durante seu complexo ciclo de vida, o parasita passa por formas intra e extracelulares em hospedeiros filogeneticamente muito distantes (revisado em Bannister e Mitchell 2003). Dentro desse contexto, a percepção do ambiente e sinalização intracelular possuem um papel essencial no ciclo de vida do parasita, possibilitando a ativação de diversos processos, como formação de gametas masculinos (Billker et al., 2004) sincronização das fases intraeritrocíticas do parasita (Beraldo et al., 2005; Hotta et al., 2000), ativação da invasão de hepatócitos durante o processo de traversing (Kumar et al., 2007; Mota et al., 2001), exposição na membrana de proteínas envolvidas na invasão de hepatócitos (Ono et al., 2008) e na invasão de eritrócitos (Singh et al., 2010).

\subsubsection{Maquinaria de sinalização celular: cálcio}

O cálcio é um íon sinalizador ubiquitário capaz de agir em um amplo espectro temporal para modular processos que variam de exocitose (milissegundos) a proliferação celular (horas, revisado em Berridge, 2001; Berridge et al., 2003). Diversos estímulos extracelulares, agindo através de vários receptores e vias diferentes podem provocar aumento de cálcio intracelular (revisado em Berridge, 2001; Berridge et al., 2003). Por outro lado, a homeostasia do íon precisa acontecer para a sobrevivência da célula, pois altas concentrações citosólicas de cálcio mantidas por muito tempo provocam apoptose. A célula dispõe de vários mecanismos para lidar com o íon: bombas de cálcio localizadas na membrana plasmática 
(PMCAs), uniporters na mitocôndria, trocadores $\mathrm{Na}^{2+} / \mathrm{Ca}^{2+}$ na membrana plasmática e SERCA (ATPase de cálcio do retículo endoplasmático) são necessários durante as reações de "desligamento" do sinal de cálcio; canais ligantes de inositol 1,4,5-trisfosfato no retículo endoplasmático e canais de cálcio na membrana plasmática funcionam durante as reações de aumento de cálcio intracelular (revisado em Berridge, 2001; Berridge et al., 2003).

A sinalização de cálcio em fases sanguíneas de Plasmodium é peculiar, pois o parasita é intracelular durante grande parte do tempo. O parasita intraeritrocítico enfrentaria um problema para utilizar o cálcio para a sinalização, pois se encontra separado do meio externo, que contém concentrações milimolar de cálcio, pela membrana do vacúolo parasitóforo e pelo citosol e membrana da hemácia. Através do aprisionamento de marcadores de cálcio ácidos, impermeáveis a membranas, Gazarini et al. (2003) demonstraram que o vacúolo parasitóforo, espaço existente entre a membrana do parasita e a membrana do vacúolo parasitóforo (MVP) é rico em cálcio. Para explicar o fenômeno, os autores sugerem que, durante a invasão, as bombas de cálcio da membrana plasmática do eritrócito invertem a sua orientação e passam a fazer parte da MVP e bombear cálcio para o vacúolo parasitóforo (Gazarini et al., 2003). A conclusão é de que o parasita intraeritrocítico possui acesso ao cálcio para eventos sinalizatórios (Gazarini et al., 2003).

Diversos grupos ajudaram a descrever os sinais extracelulares que regulam processos importantes no ciclo de vida de P. falciparum.

\subsubsection{Compostos derivados do triptofano modulam o ciclo de vida de P. falciparum}

A melatonina é uma molécula que provavelmente surgiu como uma solução para a célula detoxificar espécies reativas de oxigênio. Ela está presente em protistas, vegetais e animais. A função marcadora do ritmo circadiano seria uma característica derivada (revisado em Tan et al., 2007). Vários tecidos em vertebrados produzem melatonina a partir do aminoácido triptofano. Porém a melatonina que contribui para a sincronização dos processos fisiológicos do vertebrado ao ciclo claro/escuro é produzida por pinealócitos no período noturno e secretada na corrente sanguínea. A enzima com atividade regulada para a síntese de melatonina é a arilalquilamina N- acetiltransferase (AA-NAT) (revisado em Tan et al., 2007).

Hawking (1970) notou que o pico de febre provocado por P. vivax ocorria a cada 48 horas e correlacionaram o fenômeno com um aumento do número de merozoítos na corrente sanguínea, sugerindo que o desenvolvimento do parasita deveria ser sincrônico. A sincronicidade do parasita é perdida in vitro (Trager e Jensen, 1976) sugerindo que o sinal 
para a sincronização está associado ao hospedeiro. Os experimentos de Boyd (1929) mostraram que ao submeter o parasita a um ciclo claro/escuro invertido, a esquizogonia ocorria ao meio-dia em vez de a meia-noite; Arnold et al. (1969) mostraram que ao se pinealectomizar o hospedeiro ocorria a dessincronização do parasita, evidenciando a clara associação do ciclo ao ritmo circadiano do hospedeiro (revisado em Garcia et al., 2001).

Hotta et al. (2000) demonstraram que a melatonina é capaz de sincronizar parasitas $P$. chabaudi in vivo e in vitro e aumentar a concentração de cálcio citosólico na presença ou ausência de cálcio extracelular. Utilizando um inibidor de fosfolipase C (PLC), Hotta et al., (2000) demonstraram que esse aumento era suprimido. A dessincronização dos parasitas em camundongos pinealectomizados pode ser revertida com a administração de melatonina (Hotta et al., 2000). Além disso, Bagnaresi et al. (2008) demonstraram que quando camundongos infectados com parasitas $P$. chabaudi são expostos a luzindol, um antagonista de receptores de melatonina e agente dessincronizador das fases intraeritrocíticas (Hotta et al., 2000) há um aumento da sobrevida desses camundongos tratados com doses subótimas de cloroquina. Esses dados sugerem uma vantagem adaptativa da sincronicidade. Beraldo e Garcia CR (2005) demonstraram que derivados do triptofano (triptamina, N-acetilserotonina e serotonina) também eram capazes de promover sincronização in vitro de $P$. falciparum e aumento de cálcio citosólico. Budu et al. (2007) demonstraram que o AFMK, produto de degradação da melatonina, também tinha essas propriedades. Bagnaresi et al. (2009) demonstraram que a melatonina não é capaz de promover aumento de cálcio ou sincronizar parasitas $P$. berghei, que possuem uma infecção naturalmente dessincronizada em relação a $P$. chabaudi.

Beraldo et al. (2005) exploraram aspectos das vias de sinalização ativadas por melatonina no parasita e demonstraram que o agonista provoca um aumento de AMP cíclico, aumento que pode ser bloqueado pelo inibidor da PLC, U73122, e por um quelante intracelular de cálcio (BAPTA). Esses resultados demonstram um cross-talk entre as vias de AMP cíclico e cálcio no parasita. Em outros experimentos, os autores utilizaram parasitas marcados com o indicador citosólico de cálcio Fluo-3 e PKI, inibidor de PKA, proteína alvo do AMP cíclico. Quando estimulado com melatonina, o transiente de cálcio não foi inibido por PKI. Um análogo permeável de cAMP, 8-Bz-cAMP, foi capaz de provocar aumento de cálcio citosólico, aumento este que não foi inibido com U73122. Quando os autores adicionaram 8-Bz-cAMP após melatonina, não houve aumento de cálcio com o análogo de cAMP, demonstrando que os compostos mobilizam cálcio através de um mesmo mecanismo (Beraldo et al., 2005). 
Figura 2 - Homeostasia de cálcio e via de sinalização de melatonina em Plasmodium.

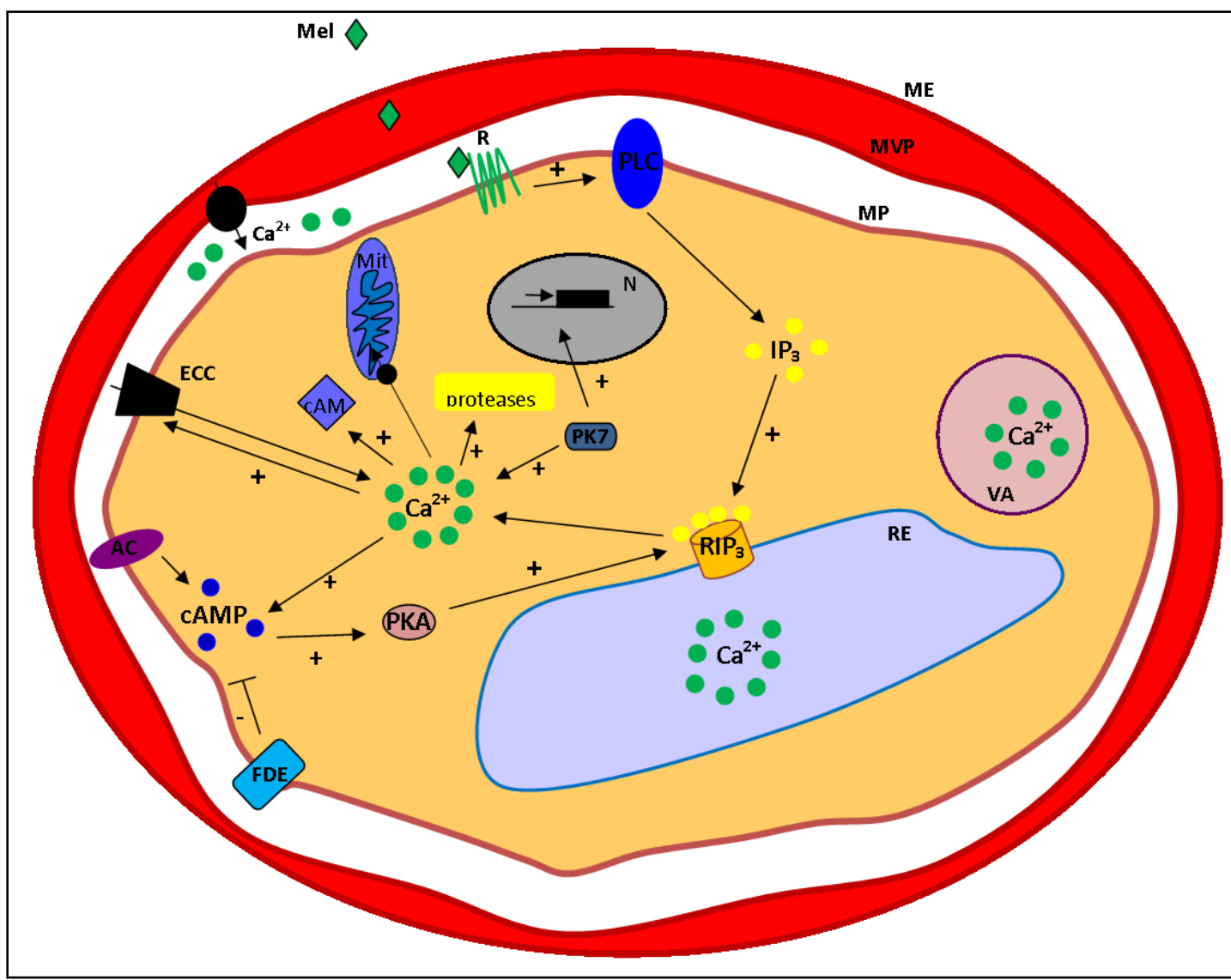

Mel: Melatonina, R: receptor, PLC: fosfolipase C, ME: membrana do eritrócito, MVP: membrana do vacúolo parasitóforo, MP: membrana do parasita, RE: retículo endoplasmático, $\mathrm{RIP}_{3}$ : receptor de $\mathrm{IP}_{3}$, PK7: proteína quinase 7, CAM: calmodulina, ECC: entrada capacitativa de cálcio, AC: adenilato ciclase, FDE: fosfodiesterase, PKA: proteína quinase A, Mit: mitocôndria, N: núcleo, VA: vacúolo ácido., AMPc: adenosina monofosfato cíclica. Fonte: Baseado nos dados de Alves et al. (2011), Beraldo et al. (2005), Beraldo et al. (2007), Farias et al. (2005), Garcia CR et al. (1998), Gazarini et al. (2003), Gazarini e Garcia (2004), Koyama et al. (2012),Varotti et al. (2003).

Existe, portanto, um complexo cross talk entre vias sinalizatórias em Plasmodium (Figura 2). Entre os efetores do cálcio em Plasmodium são cisteíno-proteases, conforme demonstrado por Farias et al. (2005).

$\mathrm{Na}$ fase de gametócito a maquinaria capaz de transduzir sinais de cálcio desempenha um papel importante na formação de gametas masculinos (Garcia GE et al., 1998). Billker et al. (2004), utilizando parasitas murinos $P$. berghei transfectados com aequorina-GFP (quimera gerada da fusão de um sensor luminescente de cálcio, a aequorina, e proteína fluorescente, gerando FRET) demonstraram que o ácido xanturênico, uma molécula derivada do triptofano, é capaz de promover a exflagelação de gametócitos masculinos. Além disso, Billker et al. (2004) demonstraram que a CDPK4 é um dos alvos do sinal de cálcio: parasitas nocautes para 
essa proteína não apresentaram exflagelação, apesar de os gametócitos conseguirem romper o eritrócito e se arredondarem. A família das CDPKs parece estar presente apenas em apicomplexos, plantas, algas verdes e ciliados e contém quatro motivos que ligam cálcio (EF hands) e um domínio serina/treonina quinase (Billker et al., 2004).

\subsubsection{Alguns compostos presentes em altas concentrações intracelulares são sinalizadores em Plasmodium}

\subsubsection{Esporozoítos}

Uma característica interessante de esporozoítos de Plasmodium é o traversing: passagem através de diversos hepatócitos antes da invasão da célula em que o esporozoíto sofrerá mudança de formato (round up) e desenvolvimento em merozoítos. O processo de traversing acontece sem a formação de um vacúolo parasitóforo e com contato do parasita com o meio intracelular do hepatócito, o que contrasta com o processo de invasão do hepatócito para desenvolvimento em merozoítos (Mota et al., 2001). O processo de traversing foi demonstrado utilizando-se um marcador fluorescente que tem acesso ao citosol quando do rompimento da membrana plasmática do hepatócito pelo esporozoíto. Quando a membrana plasmática é restabelecida (selada), o marcador fica preso no citosol da célula hospedeira e é visualizado após lavagem. Os autores sugerem que o traversing pode ser um processo importante para a ativação de vias de sinalização e posterior desenvolvimento dentro do hepatócito (Mota et al., 2001). De fato, a incubação de esporozoítos com extratos celulares aumenta a secreção de proteínas importantes na invasão para a membrana plasmática e, portanto, a infectividade (Mota et al., 2001). Uma provável classe de moléculas sinalizadoras importantes no processo de ativação do merozoíto seriam os nucleotídeos. De fato, a incubação de esporozoítos com nucleotídeos de uracila (UMP, UDP e UTP) induz o aumento de exposição na membrana plasmática da proteína TRAP, importante no processo de invasão 
pois liga a célula hospedeira ao motor de invasão do parasita (Ono et al., 2008). Foi demonstrado que a cascata de sinalização ativada pelos derivados de uracila no esporozoíto é a via do AMP cíclico pois um bloqueador de adenilato ciclase inibe a secreção quando os parasitas são estimulados com derivados de uracila e a utilização de um ativador de adenilato ciclase (forscolina) ou a adição de um análogo permeável de AMP cíclico (8Br-AMPc) mimetiza o efeito dos compostos purinérgicos (Ono et al., 2008).

Figura 3 - Secreção apical de proteínas em esporozoítos de Plasmodium após traversing.

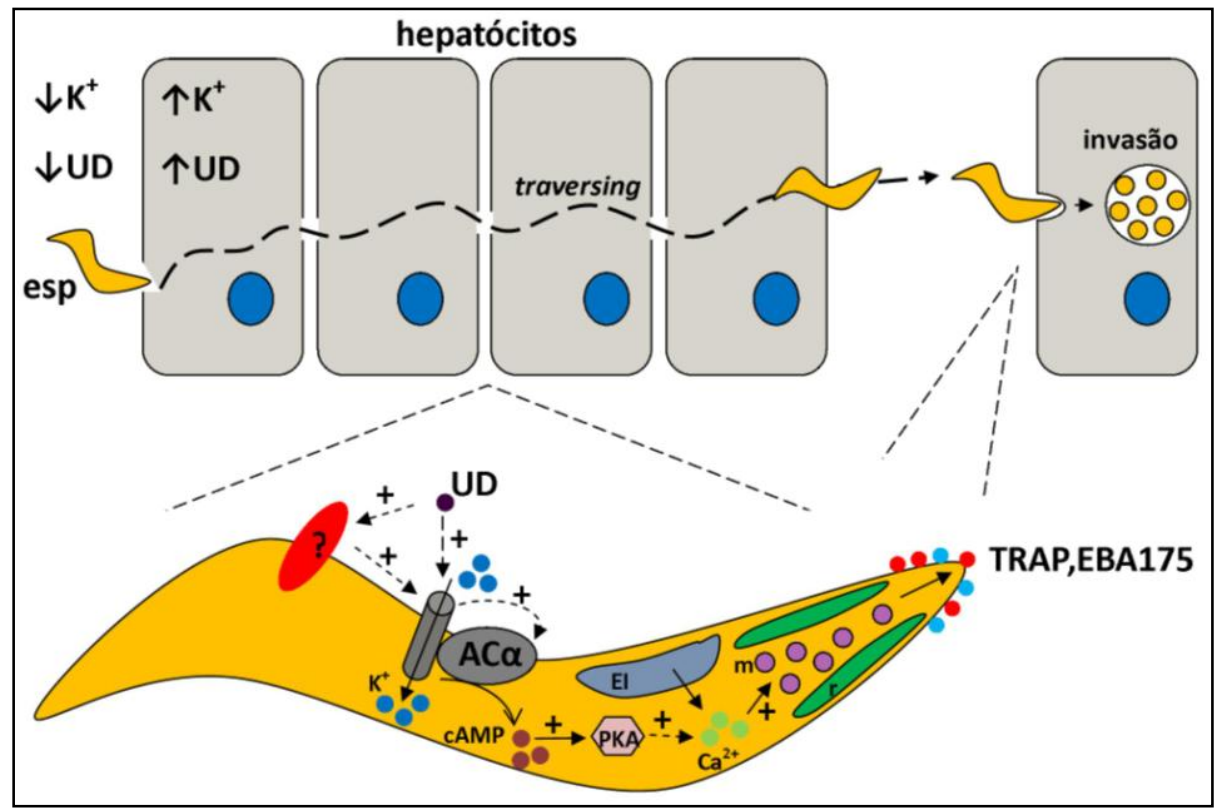

Nucleotídeos de uracila ativam um receptor hipotético (?) ou diretamente o domínio canal de potássio da adenilato ciclase $\alpha$, levando à geração de AMP cíclico, ativação da PKA, aumento de cálcio intracelular e secreção das roptrias. UD: nucleotídeos de uracila, esp: esporozoíto, EBA 175: proteína de ligação a eritrócito 175, TRAP: proteína adesiva relacionada à trombospondina, $\mathrm{AC} \alpha$ : adenilato ciclase alfa, EI: estoque interno de cálcio, cAMP: AMP cíclico, m: micronemas, r: roptria. Setas tracejadas indicam processos hipotéticos. Fonte: Baseado em Kumar et al. (2007) e Ono et al. (2008).

Além do AMP cíclico, os autores demonstram que o cálcio de estoques internos, mas não do meio externo, também é importante no processo: a utilização de um quelante intracelular de cálcio inibe a secreção de TRAP, enquanto um quelante extracelular de cálcio não inibe a exposição de TRAP na membrana (Ono et al., 2008). Os autores fortalecem a hipótese da participação de AMP cíclico no processo de ativação do merozoíto por nucleotídeos de uracila através de um nocaute da adenilato ciclase $\alpha$ de Plasmodium berghei (Ono et al., 2008). Os parasitas nocautes expõem menos TRAP na membrana quando estimulados com derivados de uracila comparados aos parasitas selvagens (Ono et al., 2008). Interessantemente, a adenilato ciclase $\alpha$ também possui um domínio canal de potássio. Quando se diminui a concentração de 
potássio no meio extracelular, a exposição de TRAP na membrana estimulada por derivados de uracila é reduzida (Ono et al., 2008). Assim, outro sinal que poderia agir em conjunto com compostos purinérgicos é o íon $\mathrm{K}^{+}$. A concentração de potássio varia de aproximadamente 5 $\mathrm{mM}$ no meio extracelular para $150 \mathrm{mM}$ no meio intracelular. Quando esporozoítos são incubados em tampão rico em potássio e colocados em cultura com células HepG2 observa-se um aumento de parasitemia em relação a esporozoítos incubados com tampão rico em $\mathrm{Na}^{+}$ (Kumar et al., 2007). Caso, no entanto, sejam utilizados inibidores de canais de potássio (cloreto de tetraetilamônio ou quinino) ocorre uma diminuição da parasitemia, em relação a esporozoítos tratados com tampão rico em $\mathrm{K}^{+}$(Kumar et al., 2007). Porém um ensaio de microarranjo de cDNA demonstrou que a diferença observada não tem um componente de modificação transcricional grande pois foram observadas diferenças iguais ou maiores de duas vezes apenas para sete genes (Kumar et al., 2007). A Figura 3 sintetiza os resultados obtidos pelos autores quanto ao efeito do traversing para a invasão de Plasmodium.

\subsubsection{Merozoítos}

É interessante que, em merozoítos da fase sanguínea de Plasmodium, a diminuição da concentração de $\mathrm{K}^{+}$sinaliza a secreção de proteínas importantes para a invasão a partir de micronemas, vesículas da região apical do parasita, via o segundo mensageiro cálcio (Singh et al., 2010). O processo é dependente de PLC $\beta$, conforme demonstrado pela inibição da secreção apical de proteínas ao se utilizar o composto U73122 (Singh et al., 2010). Subsequentemente, a ligação do merozoíto a receptores no eritrócito diminui a concentração citosólica de cálcio do parasita. O parasita é exposto às altas concentrações de potássio do citosol do eritrócito em fases jovens, porém em fases maduras a concentração de potássio no eritrócito diminui (Staines et al., 2001). Assim, o parasita é capaz de utilizar baixas concentrações de potássio como um sinal para se preparar para invadir um novo eritrócito (Figura 4, Singh et al., 2010). 
Figura 4 - A diminuição de potássio extracelular gera a secreção apical de micronemas no merozoíto da fase sanguínea.

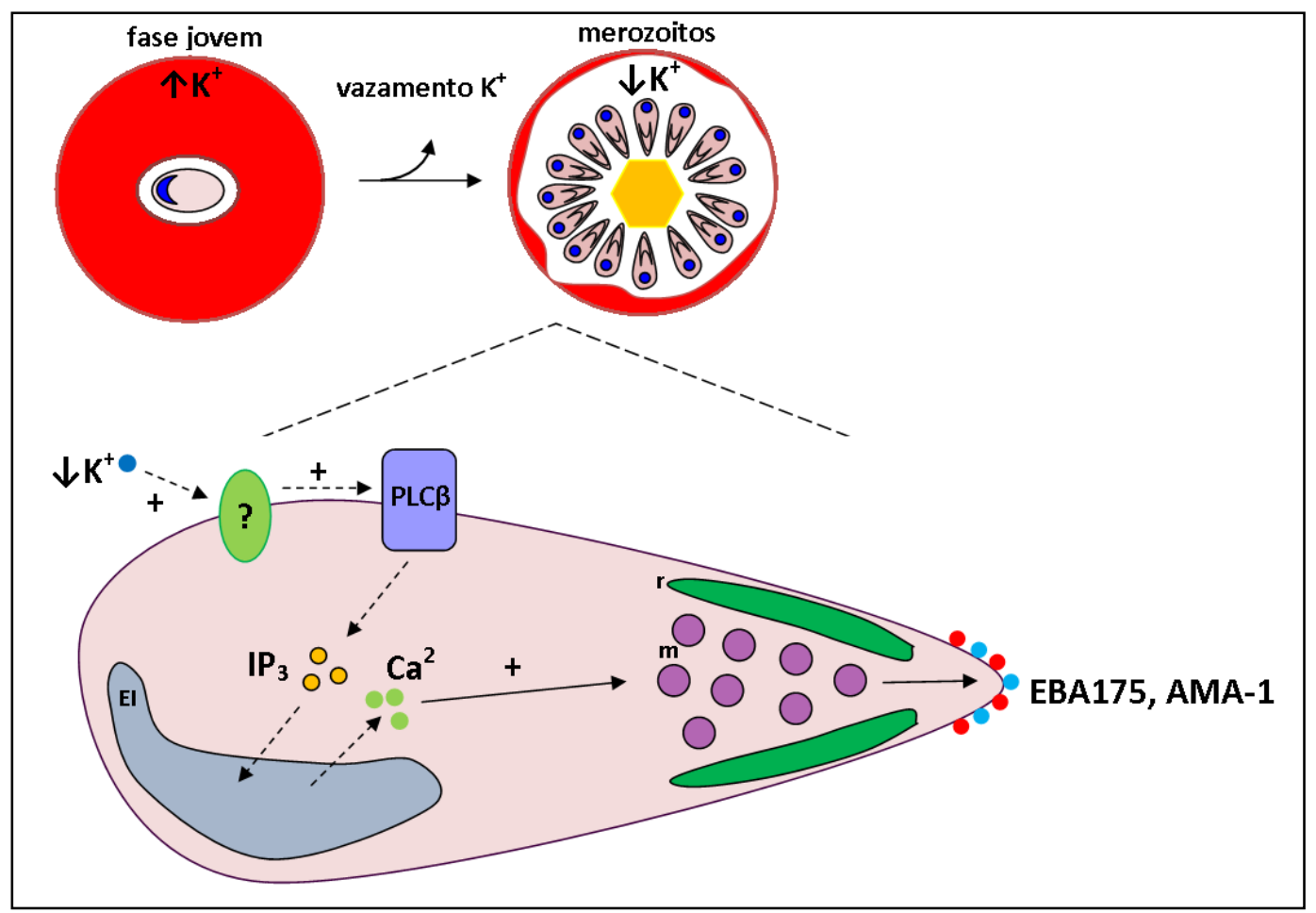

Baixo potássio extracelular ativa,via um receptor hipotético (?) a fosfolipase C beta (PLC $\beta$ ), que leva ao aumento de cálcio intracelular provavelmente através da geração de inositol 1,4,5 trifosfato $\left(\mathrm{IP}_{3}\right)$ e mobilização de estoques internos (EI). O cálcio provoca a secreção de micronemas (m), contendo as proteínas EBA 175 (erithrocyte binding antigen 175) e AMA-1 (apical membrane antigen-1). A secreção das roptrias (r) é um processo dependente de ligação ao eritrócito a ser invadido. Setas tracejadas indicam processos hipotéticos. Fonte: baseado em Singh et al. (2010).

Purinas também são importantes na invasão de eritrócitos por merozoítos de $P$. falciparum. Purinas induzem a ativação de vias sinalizadoras tanto no eritrócito quanto no parasita.

Em eritrócitos humanos existem receptores de adenosina, receptores $\beta$-adrenérgicos e proteína $\mathrm{G} \alpha_{\mathrm{s}}$, que ativa a adenilato ciclase (Harrison et al., 2003). A proteína $\mathrm{G} \alpha_{\mathrm{s}}$ é internalizada no vacúolo parasitóforo juntamente com receptores $\beta$-adrenérgicos (Harrison et al., 2003) enquanto outras proteínas de membrana de eritrócito, como banda 3 não são internalizadas (Murphy et al., 2007). Sinalização via proteína G do eritrócito é importante no processo de invasão de $P$. falciparum, pois a incubação de culturas de parasitas com um peptídeo de parte de $\mathrm{G} \alpha_{s}$, importante na interação com receptores, inibe a entrada de parasitas no eritrócito (Harrison et al., 2003). Além disso, a utilização de agonistas do receptor de adenosina e do receptor $\beta$-adrenérgico aumentam a invasão, que é inibida ao se utilizar 
concomitantemente antagonistas desses receptores (Harrison et al., 2003). Os autores sugerem que a elevação dos níveis de AMP cíclico, gerada pela ativação da proteína $\mathrm{G} \alpha_{\mathrm{s}}$ do eritrócito, pode levar a um remodelamento do citoesqueleto da hemácia, facilitando a invasão (Harrison et al., 2003).

Recentemente, foi demonstrado que as fases intraeritrocíticas de P. falciparum de trofozoíto e esquizonte apresentam um aumento sustentado de $\left[\mathrm{Ca}^{2+}\right]_{\mathrm{cit}}$ quando estimulados com os nucleotídeos ATP e UTP (Levano-Garcia et al., 2010). Interessantemente, a resposta foi completamente abolida na ausência de cálcio extracelular (Levano-Garcia et al., 2010). Os autores sugerem o envolvimento de um receptor de ATP do tipo canal de cálcio. Utilizando diversos inibidores de receptores purinérgicos disponíveis comercialmente, os autores notaram, interessantemente, que todos os compostos foram capazes de abolir o aumento citosólico de cálcio, sugerindo a presença de um receptor muito diferente dos receptores identificados até agora (Levano-Garcia et al., 2010). Incubando os parasitas na presença de apirase, uma enzima que hidrolisa ATP, os autores demonstraram que a invasão de eritrócitos pelo parasita é diminuída significativamente (Levano-Garcia et al., 2010) sugerindo assim um papel funcional do ATP na invasão. A participação do ATP na invasão é reforçada pela incubação de culturas do parasita com inibidores de receptores purinérgicos, que também diminuem a invasão, porém não impedem a progressão do ciclo intraeritrocítico do parasita, demonstrando não haver efeito tóxico dos compostos (Figura 5, Levano-Garcia et al., 2010). A origem do ATP extracelular que estimula o parasita ainda não foi demonstrada. Foi demonstrado que ATP é liberado através de canais na membrana do eritrócito em células infectadas por P. falciparum, porém não em eritrócitos não infectados (Akkaya et al., 2009). Utilizando técnicas de eletrofisiologia (clampeamento em célula inteira), os autores demonstraram que um inibidor de canal aniônico diminui o fluxo de ATP para fora da célula (Akkaya et al., 2009). Pode ser argumentado porém, que o ATP assim liberado é rapidamente degradado, não ficando disponível para estimular o parasita. O ATP extracelular, por outro lado, também pode ser gerado através da perturbação que o parasita causa na membrana da hemácia antes da invasão (Dvorak et al., 1975). Pressão em membranas é um mecanismo conhecido de liberação de ATP (Wan et al., 2008). Outra possível proveniência do ATP é durante a lise do eritrócito no final da esquizogonia. 
Figura 5 - ATP gera aumento de cálcio em fases intraeritrocíticas do parasita (par) através de um receptor do tipo canal de cálcio.

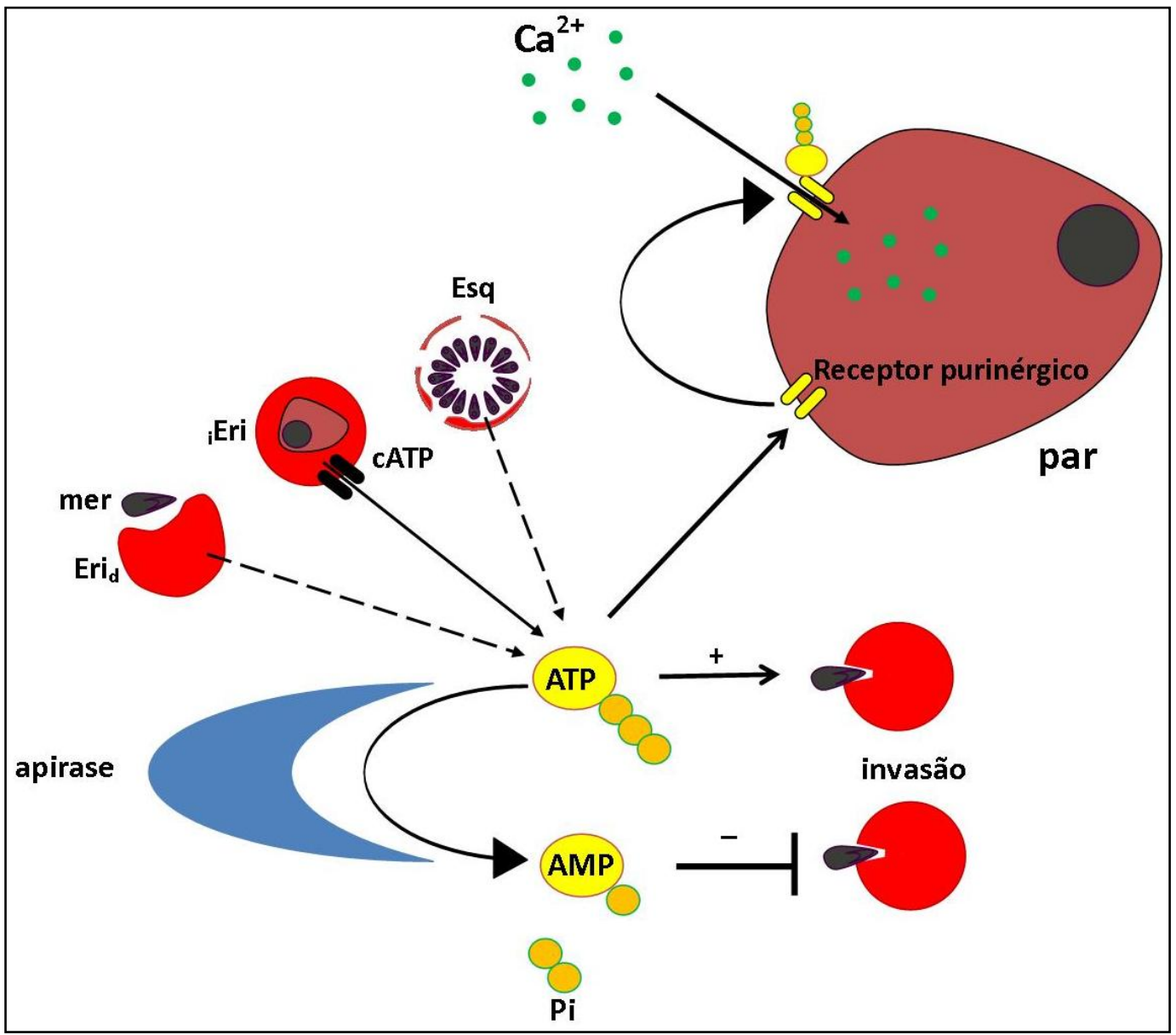

Ao menos três processos podem gerar ATP extracelular: deformação do eritrócito (Eri $\left.{ }_{d}\right)$ pelo merozoíto (mer) no momento da invasão, canais de ATP (cATP) induzidos pelo parasita no eritrócito infectado ( ${ }_{\mathrm{i}}$ Eri), ruptura do eritrócito carregando fases maduras do parasita. A diminuição de ATP no meio extracelular através do uso de uma apirase diminui a invasão do parasita. Pi: fosfato inorgânico. Setas tracejadas apresentam processos hipotéticos. Fonte: Modificado de Budu e Garcia (2012).

\subsection{O Sistema de Sinalização Purinérgico é ubiquitário entre os seres vivos}

Receptores para purinas provavelmente surgiram cedo na evolução dos seres vivos (revisado em Burnstock e Verkhratsky, 2009). A vida primitiva evoluiu em um ambiente aquático, no qual a opção de sinalizadores se restringia a moléculas solúveis em água, que não fossem abundantes no meio (o que excluiria alguns íons) e que estivessem disponíveis em grande quantidade no interior de organismos (revisado em Burnstock e Verkhratsky, 2009). As purinas são moléculas ubiquitárias, presentes em grande concentração no interior de células por fazerem parte de um grande número de reações enzimáticas celulares endergônicas e constituem o material genético da célula. Além disso, podem ser liberadas para o meio extracelular por processos diferentes: lise celular, exocitose, canais de membrana 
e transportadores (revisado em Burnstock e Verkhratsky, 2009). Os três últimos processos são considerados fisiológicos. Transportadores $\mathrm{ABC}$ e receptores de ATP do tipo canal são sugeridos como prováveis vias de liberação de ATP para o meio extracelular (revisado em Burnstock, 2009).

Por serem moléculas sinalizadoras altamente conservadas, não é surpreendente que organismos dos filos mais diversos possuam algum tipo de resposta a elas: bactérias, nas quais foram observadas aceleração ou inibição do crescimento em resposta a ATP; Paramecium (protozoário ciliado), no qual ATP e GTP geram despolarização da célula devido a influxo de magnésio e sódio via canais de membrana, o que gera a abertura de canais de cálcio; Ostreococcus taurii (alga unicelular, com um genoma de 1 bilhão de anos) que possui um receptor purinérgico do tipo canal iônico; e vertebrados, nos quais ATP participa como cotransmissor tanto no sistema nervoso central quanto no sistema nervoso periférico, além de muitos outros tipos celulares não nervosos (revisado em Burnstock e Verkhratsky, 2009). Em lagartos, foi demonstrado farmacologicamente que eritrócitos das espécies Ameiva ameiva e Tupinambis merianae possuem receptor metabotrópico para ATP e UTP (Beraldo et al., 2001). Em eritrócitos de Iguana iguana há evidências para um receptor para ATP, GTP e UTP porém este parece ser ionotrópico, pois ao se retirar o cálcio do meio extracelular a resposta é abolida (revisado em Bagnaresi et al., 2007). As diferenças farmacológicas suportam a classificação filogenética desses animais, ressaltando a importância desta via de sinalização (revisado em Bagnaresi et al., 2007).

Os efeitos mediados pelos receptores de ATP são os mais diversos, dependendo não apenas do tipo celular mas também do subtipo de receptor expresso: efeitos apoptóticos, proliferação celular, diferenciação, mobilidade celular, quimiotaxia, secreção e neuromodulação são alguns dos processos mediados, em um amplo espectro temporal (revisado em Burnstock, 2009).

\subsubsection{Subtipos de Receptores Purinérgicos}

Os receptores purinérgicos em humanos estão divididos em duas grandes classes: P1 e P2. Os últimos estão subdivididos em P2X e P2Y (Burnstock, 2007; Burnstock, 2009; Burnstock e Verkhratsky, 2009). Receptores do tipo P1 possuem sete domínios transmembrânicos, têm como ligante a adenosina e são divididos em quatro subtipos: $A_{1}, A_{2 A}$, $A_{2 B}$ e $A_{3}$. Esses receptores em geral acoplam-se à adenilato ciclase via proteína $G_{i}$ ou $G_{s}$, 
porém acoplamento com proteína $G_{q / 11}$ e PLC também foi reportado para o subtipo $A_{2 B}$ (Burnstock, 2007).

A família P2 é constituída por receptores ativados por ATP e outros nucleotídeos. Receptores P2X são canais iônicos permeáveis a sódio, potássio, cálcio entre outros, divididos em sete subtipos $\left(\mathrm{P} 2 \mathrm{X}_{1-7}\right)$, alguns com splicing alternativo dos genes codificantes. $\mathrm{O}$ canal iônico funcional é formado por três subunidades, cada qual possuindo dois domínios transmembrânicos com os domínios amina e carboxila terminais intracelulares. Os canais funcionais podem ser homoméricos ou heteroméricos, sendo que alguns subtipos são funcionais apenas na forma heteromérica e outros têm seletividade a cátions diminuída quando expostos durante muito tempo a ATP (i.e., passam a permitir a entrada de cátions maiores, Burnstock, 2007). A família P2Y é composta por 8 subtipos de receptores de sete domínios transmembrânicos, a maioria dos quais transduzem sinal através da proteína Gq, acoplando PLC e levando à produção de $\mathrm{IP}_{3}$ (Burnstock, 2007). Esses receptores também podem levar, em certos tipos celulares, via proteína $\mathrm{G}$, à abertura ou fechamento de canais de potássio e canais de cálcio voltagem-dependentes de membrana (Burnstock, 2007). Efeitos downstream incluem a ativação de várias quinases como PKC, MAPK e PI3K (revisado em Volonte et al., 2006). Além disso, está descrita homodimerização de receptores P2Y e heterodimerização com outros receptores, como P1 e $\beta$-adrenérgico, o que modifica a farmacologia dos receptores P2Y. Por exemplo, no caso de heterodimerização de P2Y com P1 o estímulo com ATP gera acoplamento com a proteína $G_{i}$, inibição da adenilato ciclase e diminuição da concentração intracelular de AMP cíclico em vez de acoplamento com $\mathrm{G}_{\mathrm{q}} \mathrm{e}$ consequente ativação da PLC, efeito da maioria dos subtipos de receptores P2Y (revisado em Burnstock, 2007; Volonte et al., 2006). Receptores P2Y podem ser ativados também por pirimidinas, como CTP e UTP (Burnstock, 2007).

\subsection{Receptores de sete domínios transmembrânicos (7-TMR): sinalização, expressão, tráfego e classificação}

A existência física dos receptores de sete domínios transmembrânicos (7-TMRs) foi, durante muito tempo, colocada em dúvida. Avanços iniciais se deram através do estudo dos 7TMRs $\alpha$ e $\beta$-adrenérgicos. Através do uso de colunas de sefarose ligadas a antagonistas de receptores $\alpha$ e $\beta$-adrenérgicos, nas quais se passavam preparações de membrana solubilizadas, foi possível verificar que os receptores eram glicoproteínas de cadeia única e tinham entre 60 e $65 \mathrm{kDa}$ (revisado em Lefkowitz, 2007). Com os receptores $\beta$-adrenérgicos purificados em 
mãos foi possível incluí-los em vesículas de fosfolipídeos reconstituí-los em oócitos de Xenopus que não possuem tais receptores. Ensaios de medida da atividade da adenilato ciclase mostraram que havia geração de AMP cíclico em oócitos de Xenopus após a reconstituição dos receptores, em um sistema previamente desprovido de atividade $\beta$-adrenérgica (Cerione et al., 1983; revisado em Lefkowitz, 2007).

A identificação da estrutura primária dos primeiros 7-TMRs tem uma história interessante. A rodopsina, receptor de luz presente em cones, teve a sua sequência de aminoácidos determinada por degradação de Edman e sequenciamento proteico (Ovchinnikov, 1982). Isso foi possível pois a proteína está presente em grande quantidade na membrana plasmática. Já o receptor $\beta$-adrenérgico é quase que um contaminante na preparação de membranas (revisado em Lefkowitz, 2007). Apenas a sequência de alguns aminoácidos foi identificada e esta utilizada para gerar oligonucleotídeos que foram usados para achar a sequência completa em uma biblioteca de cDNA. A sequência de aminoácidos do receptor mostrou sete domínios transmembrânicos, assim como o receptor de rodopsina. Assim se notou que esses sete domínios poderiam ser um aspecto comum desses receptores (revisado em Lefkowitz, 2007). Atualmente, sabe-se que 7-TMRs são a maior classe de receptores de sinal identificados, incluindo por volta de 1000 membros. Eles podem ser ativados por uma ampla gama de estímulos, como peptídeos, luz, íons, proteases, lipídeos e nucleotídeos (revisado em Lefkowitz, 2007).

Durante a tradução, 7-TMRs são importados para o retículo endoplasmático através da ligação de uma partícula reconhecedora de sinal ao peptídeo nascente. Isso recruta o ribossomo e o peptídeo nascente para canais do retículo endoplasmático, formados pelo complexo sec61p. Após a tradução e liberação do receptor para a membrana do retículo endoplasmático, o 7-TMR interage com chaperonas (Bip, calnexina, calreticulina, heat shock proteins), que estabilizam conformações intermediárias do receptor, auxiliando em seu dobramento. Caso o receptor não adquira um dobramento correto, as chaperonas continuam ligadas a ele e o receptor é degradado pelo proteassomo. Receptores corretamente dobrados são exportados, via vesículas recobertas com COPII para o complexo de Golgi, e finalmente para a membrana plasmática. O transporte, e ligação de vesículas a membranas é controlado por diversas GTPases, específicas para cada compartimento, chamadas Rab (revisado em Dong et al., 2007).

7-TMRs classicamente utilizam a proteína $\mathrm{G}$ heterotrimérica como transdutora de sinal (revisado em Lefkowitz, 2007). Proteínas G heterotriméricas possuem três subunidades: $\alpha, \beta$ e భ. Ao ligar um agonista, o 7-TMR é estabilizado em uma conformação ativa, expondo sítios 
de interação com a proteína $G$ heterotrimérica. A interação entre a proteína $G$ e o receptor ativado promove a troca de GDP por GTP na subunidade $\alpha$ da proteína G, separando a subunidade $\alpha$ das subunidades $\beta \gamma$. A subunidade $\alpha$ pode ativar geradores de segundosmensageiros, como fosfolipase $\mathrm{C}$ (no caso de uma subunidade $\alpha$ do subtipo $q$ ) ou adenilato ciclase (no caso de uma subunidade $\alpha$ do subtipo $s$ ). Ainda, subunidades $\alpha$ do tipo $i$ podem diminuir a atividade da adenilato ciclase. A fosfolipase $\mathrm{C}$ ativada leva à geração do segundomensageiro inositol -1,4,5-trifosfato $\left(\mathrm{IP}_{3}\right)$, enquanto a adenilato ciclase leva à geração do segundo-mensageiro AMP cíclico a partir de ATP. $\mathrm{IP}_{3}$ induz aumento de cálcio citosólico que ativa diversos efetores, dentre eles a proteína quinase C. O AMP cíclico, por sua vez, pode ativar o efetor proteína quinase A, entre outros (revisado em Selbie e Hill, 1998).

Diversas proteínas que agem na dessensibilização de receptores de sete domínios transmembrânicos foram descobertas; entre elas podem ser citadas quinases de receptores ligados a proteínas $\mathrm{G}(\mathrm{GRKs})$ e $\beta$-arrestinas. As primeiras fosforilam o receptor ativado, recrutando a $\beta$-arrestina. As últimas servem como proteínas andaime e adaptadoras, recrutando várias proteínas para o receptor, dentre as quais se destacam a fosfodiesterase 4, que atua na degradação do AMP cíclico levando à diminuição da atividade da proteína quinase A e consequentemente parando os efeitos de sinalização dependentes de proteína $\mathrm{G}$, e clatrina, proteína associada à internalização do receptor. A $\beta$-arrestina pode ser ubiquitinada, levando à internalização do receptor em vesículas (sendo esse processo dependente da clatrina, revisado em Lefkowitz et al., 2006). O próprio receptor pode ser ubiquitinado durante a internalização, o que pode levar à degradação pelo lisossomo (revisado em Marchese et al., 2008). Alternativamente, o receptor pode ser reciclado para a membrana plasmática através de interação de fatores com motivos na porção C-terminal do receptor (Moore et al., 2007). É interessante que apesar de agir inibindo a transdução de sinal via proteína G, a $\beta$-arrestina recruta MAP quinases. Essas proteínas são exclusivamente citosólicas, contrastando com MAP quinases ativadas através de PKC, que se localizam também no núcleo. Assim, existe uma segunda via de transdução de sinal via receptores de sete domínios transmembrânicos que é independente de proteína G. Existem agonistas tendenciosos que ativam apenas a sinalização via $\beta$-arrestina (revisado em Lefkowitz et al., 2006). 
Em suma, a magnitude da resposta celular a partir do estímulo de determinado 7-TMR depende dos processos de transporte anterógrado, dessensibilização, degradação e reciclagem para a membrana plasmática (Figura 6).

Figura 6 - Exportação e Sinalização de 7-TMR.

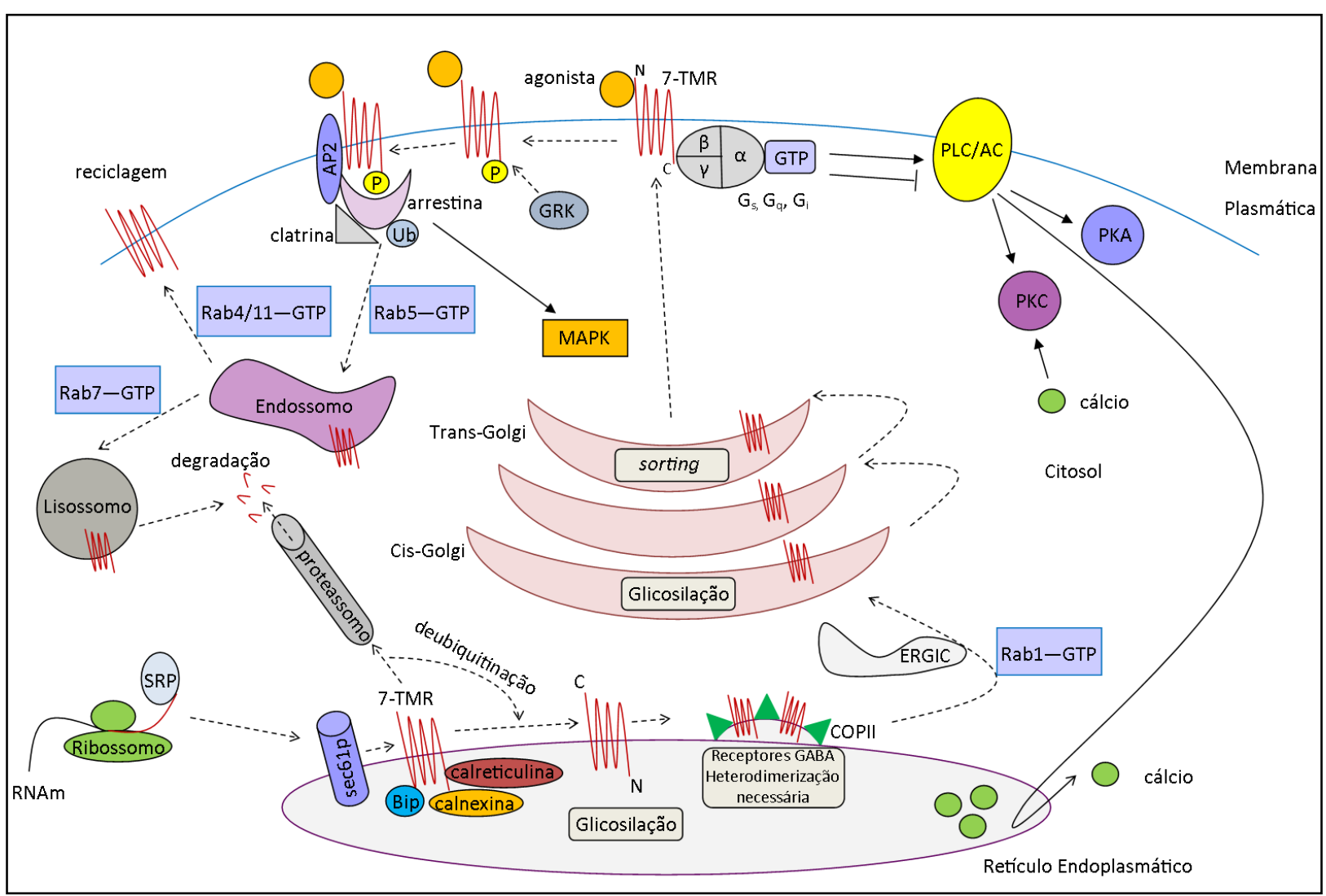

AP2: proteína adaptadora 2, Ub: ubiquitina, SRP: partícula reconhecedora de sinal, PKA: proteína quinase A, PKC: proteína quinase C. Setas tracejadas: transporte, Setas cheias: ativação de um processo, traço perpendicular: inibição. Fonte: Baseado em Selbie e Hill (1998), Dong et al. (2007), Lefkowitz (2007) e Marchese et al. (2008).

Dentro da grande diversidade de 7-TMRs, muitos ainda são órfãos (sem agonistas identificados). Os receptores são subdivididos em famílias distintas com base em classificação em similaridade de sequência. Há, porém, diversas propostas de grupos de classificação (Kolakowski, 1994, Fredriksson et al., 2003). A classificação de Freddrikkson, 2003, divide os receptores em cinco famílias: rodopsina, secretina, adesão, Frizzled/Taste2 e glutamato.

A família da rodopsina é a maior, possuindo 672 receptores identificados (revisado em Lagerstrom et al., 2008) dos quais mais da metade são órfãos. A família é bastante heterogênea, porém uma característica comum é a presença de uma cauda $\mathrm{N}$-terminal 
extracelular curta. A essa família pertencem receptores purinérgicos do tipo P2Y além dos dois receptores cristalizados: rodopsina e $\beta$-adrenérgico (Millar et al., 2010). A cristalização desses receptores em estados inativos e ativos permitiu a descoberta de diferenças conformacionais entre os dois estados. Particularmente, os domínios transmembrana 5 e 6 da rodopsina têm um significativo deslocamento entre os dois estados (Millar et al., 2010). Os agonistas dos receptores da família rodopsina costumam se ligar aos domínios transmembrana e loops extracelulares (revisado em Lagerstrom et al., 2008).

A família dos receptores secretina têm sítios de ligação de hormônio extracelulares, sendo a porção N-terminal importante nessa função. Em geral ligam hormônios peptídicos (revisado em Lagerstrom et al., 2008). A família de receptores adesão é formada por membros que ligam agonistas de matriz extracelular, possuindo um grande domínio N-terminal, bastante distinto entre os seus membros (revisado em Lagerstrom et al., 2008). Os receptores do tipo glutamato ligam seus agonistas na região N-terminal. Membros da família são o receptor sensor de cálcio, gabaérgicos, e metabotrópicos de glutamato, além de receptores gustativos (revisado em Lagerstrom et al., 2008). A última família, Frizzled/Taste2 engloba receptores do frizzled, ativados pela proteína Wnt e importantes no desenvolvimento embrionário e polaridade tecidual. Receptores Taste2 estão relacionados à gustação de amargo e possuem alta diversidade entre espécies (revisado em Lagerstrom et al., 2008).

\subsubsection{Identificação de 7-TMR no genoma de P. falciparum}

Aspectos downstream da sinalização celular via melatonina e outras moléculas estão caracterizados com certo detalhamento no parasita, porém nenhuma informação havia sobre receptores dos hormônios em Plasmodium. Há a possibilidade da participação de 7-TMR na sinalização via melatonina em Plasmodium. Isso é sugerido pelos dados de inibição obtidos com o antagonista de receptor de melatonina do tipo MT2 luzindol (Beraldo e Garcia CR, 2005; Hotta et al., 2000) e participação da fosfolipase C na sinalização (Beraldo e Garcia CR, 2005; Hotta et al., 2000).

O sequenciamento do genoma de Plasmodium falciparum, cepa 3D7, foi concluído em 2002 (Gardner et al., 2002). O genoma nuclear de 23 Mb está organizado em 14 cromossomos e apresenta cerca de $80 \%$ de bases A-T. Aproximadamente $60 \%$ das 5300 ORFs anotadas no genoma não apresentam função predita devido às proteínas codificadas não apresentarem similaridades em nível de estrutura primária com outros organismos já sequenciados. Em uma primeira análise, não foram encontrados receptores de melatonina no genoma de $P$. 
falciparum. Tampouco foram encontradas proteínas $\mathrm{G}$ clássicas, apesar de existirem evidências bioquímicas de sua existência (Dyer e Day, 2000).

A partir dos dados do genoma, duas hipóteses poderiam ser elaboradas: a) o parasita se diferenciou tanto de outros organismos que comparações de similaridades são dificultadas ou b) a riqueza em bases A-T "mascara" as similaridades existentes. Sabe-se que a riqueza de A$\mathrm{T}$ promove a maior frequência de certos aminoácidos, como lisina e asparagina, e a menor frequência de outros, como arginina, alanina e prolina. Isso causa regiões de baixa complexidade expostas a baixa pressão seletiva. Callebaut et al. (2005) conseguiu identificar fatores basais de transcrição associados à RNA polimerase II hipotetizando que os aminoácidos deveriam ser conservados em centros hidrofóbicos de domínios globulares de proteínas e utilizando comparações em nível de estrutura secundária. Baseando-se apenas em comparação de sequências, estudos anteriores não haviam sido capazes de identificar esses fatores (Coulson et al., 2004) bastante conservados em eucariotos. Assim, é possível que a riqueza em A-T do genoma mascare similaridades existentes entre algumas ORFs de P.falciparum e outros eucariotos.

Utilizando métodos in silico restringentes, Madeira et al. (2008) identificaram quatro fortes candidatos a 7-TMRs chamados PFSR1, PFSR10, PFSR12 e PFSR25. Dois dos receptores putativos -PFSR10 e PFSR12- possuem similaridades com 7-TMRs de outros organismos (Madeira et al., 2008) suportando sua classificação dentro da categoria. Os receptores tiveram a expressão demonstrada no ciclo intraeritrocítico através de real-time PCR (Madeira et al., 2008). 


\section{OBJETIVOS}

Os objetivos do trabalho foram caracterizar funcionalmente dois receptores hipotéticos de sete domínios transmembrânicos de Plasmodium falciparum-PFSR10 e PFSR25. Com a finalidade de obter evidências funcionais dos receptores, os objetivos específicos incluíram ensaios em Plasmodium falciparum e em sistema heterólogo:

a) demonstração da expressão e localização de pfsr10 e pfsr25 no ciclo eritrocítico de Plasmodium falciparum através de western blot e imunofluorescência;

b) identificação de prováveis parceiros moleculares dos receptores putativos pfsr10 e pfsr25 através de ensaios de imunoprecipitação;

c) identificação do efeito dos anticorpos anti-pfsr10 e anti-pfsr25 na invasão de $P$. falciparum;

d) ensaios de dinâmica de cálcio em $P$. falciparum com parasitas nocaute para PFSR25;

e) ensaios de contagem de fases intraeritrocíticas em $P$. falciparum;

f) demonstração da expressão e localização de pfsr10 e pfsr25 em sistema heterólogo (células de mamífero) através de western blot e imunofluorescência;

g) ensaios de dinâmica de cálcio em linhagens de células de mamíferos transfectadas com PFSR10 ou PFSR25;

h) perfil de fosforilação em linhagem de células de mamíferos transfectadas com PFSR10. 


\section{MATERIAIS E MÉTODOS}

\subsection{Cultivo de células de mamíferos}

Células de mamíferos foram cultivadas em estufa com atmosfera de $\mathrm{CO}_{2}$, a $37{ }^{\circ} \mathrm{C}$. O meio de cultura utilizado foi DMEM (Gibco, E.U.A.), suplementado com 10\% de soro fetal bovino (Cultilab, Brasil) e estreptomicina/penicilina (100 $\mu \mathrm{g} / \mathrm{mL}$, Cultilab, Brasil). Células foram repicadas utilizando solução de tripsina/EDTA (Cultilab, Brasil). Células de mamíferos HEK293T foram utilizadas até a vigésima passagem.

\subsection{Cultivo e sincronização de fases intraeritrocíticas de $P$. falciparum}

Plasmodium falciparum foi mantido em cultura conforme descrito em Trager e Jensen, (1976) e sincronizado, quando indicado, através do método do sorbitol, segundo Lambros e Vanderberg (1979).

\subsection{Clone de $P$. falciparum nocaute para pfsr25}

O nocaute de pfsr25 em $P$. falciparum e a seleção clonal foram executados pelo Dr. Julio Levano Garcia e pela Dra Miriam Moraes, respectivamente, utilizando o plasmídeo pCAM-BSD, cedido pelo prof. Christian Doerig (Dorin-Semblat et al., 2008).

\subsection{Plasmídeos para expressar PFSR10 e PFSR25 em células de mamíferos}

As sequências das ORFs completas de PFSR10 e PFSR25 são flanqueadas pelos sítios de enzima de restrição Xho-I (5’) e Bam-HI (3’). As ORFs possuem uma sequência consenso KOZAK (GCCGCC) inserida na extremidade 5' e uma sequência para o epítopo FLAG em sua porção 3'. O epítopo FLAG permite o monitoramento da expressão através de anticorpo monoclonal anti-FLAG M1 (Sigma, E.U.A.). A estratégia de expressão foi elaborada pela Doutora Luciana Madeira. As sequências foram códon-otimizadas para expressão em células de mamíferos pela empresa DNA 2.0 (www.dna20.com, E.U.A.). As sequências foram clonadas em plasmídeo pcDNA 3.1 (-) (Invitrogen, E.U.A.). 


\subsection{Anticorpo anti-pfsr 10}

O anticorpo anti-pfsr10 foi desenvolvido pela empresa Genscript (www.genscript.com, E.U.A.) em coelho, utilizando-se como epítopo o peptídeo N-terminal IFENVGISTTDNKN da proteína pfsr10. O pacote de serviço solicitado à empresa foi SC1031. O número de acesso da ORF de pfsr10 no banco de dados PlasmoDB (www.plasmodb.org) é PFL0765w.

\subsection{Anticorpo anti-pfsr25}

O anticorpo anti-pfsr25 foi desenvolvido pela empresa Proteimax (Brasil) em coelho, utilizando-se como epítopo os aminoácidos N-terminais GTGEVKW de pfsr25 (número de acesso PlasmoDB MAL7P1.64).

\subsection{Anticorpo anti-msp1}

O anticorpo anti-msp1(19)-GST foi cedido pelo Prof. Gerhard Wunderlich (Instituto de Ciências Biomédicas, Universidade de São Paulo, Departamento de Parasitologia).

\subsection{Detecção da expressão de pfsr10, pfsr25 e msp-1 em $P$. falciparum através de imunofluorescência}

Hemácias infectadas por Plasmodium falciparum (cepa 3D7) e merozoítos foram incubados com $5 \mu \mathrm{g} / \mathrm{mL}$ de Brefeldina A (Sigma) durante $3 \mathrm{~h}$, a $37^{\circ} \mathrm{C}$ quando indicado. Procedeu-se à lavagem com PBS (137 mM NaCl, 2,7 mM KCl, 4,3 mM Na $2 \mathrm{HPO}_{4}, 1,4 \mathrm{mM}$ $\left.\mathrm{NaH}_{2} \mathrm{PO}_{4}, \mathrm{pH} 7,4\right)$ durante $1 \mathrm{~min}, 300 \mathrm{~g}$. A lavagem foi repetida mais duas vezes. As células foram fixadas segundo protocolo modificado de Tonkin et al. (2004). A fixação foi executada em $4 \%(\mathrm{~m} / \mathrm{v})$ de paraformaldeído, 0,075\% (m/v) de glutaraldeído em PBS durante $30 \mathrm{~min}$, à temperatura ambiente. As células foram permeabilizadas com 0,1\% de Triton X-100 (Merck) em PBS durante $10 \mathrm{~min}$. Após lavagem em PBS (300 g, $1 \mathrm{~min}$ ), as células foram incubadas em solução de $0,15 \%$ glicina $(\mathrm{m} / \mathrm{v})$ e $0,24 \% \mathrm{NH}_{4} \mathrm{Cl}(\mathrm{m} / \mathrm{v})$ durante $20 \mathrm{~min}$ para redução de grupos aldeído livres. Após uma lavagem em PBS (300 g, $1 \mathrm{~min}$ ), as células foram incubadas durante $1 \mathrm{~h}$ em PBS contendo 3\% albumina bovina (m/v). Após uma lavagem com PBS, as células foram incubadas overnight a $4^{\circ} \mathrm{C}$ em $3 \%$ albumina bovina com anti-msp-1(19) 
induzido em camundongo, e/ou anti-pfsr10 (coelho) e/ou anti-pfsr25 (coelho) utilizados na diluição de 1:50, 1:250 e 1:100, respectivamente. Após três lavagens com PBS, as células foram incubadas com o anticorpo secundário anti-IgG coelho conjugado a Alexa 488 (Invitrogen) e/ou anti IgG camundongo conjugado a Alexa 546 (Invitrogen), na diluição de 1:300 em PBS contendo 3\% de albumina bovina $(\mathrm{m} / \mathrm{v})$ durante $1 \mathrm{~h}$ à temperatura ambiente, sob agitação. Após três lavagens em PBS (1 min, 300g), as células foram incubadas com marcador de DNA DAPI (Invitrogen) $0.01 \mathrm{mg} / \mathrm{mL}$ durante 5 min. Após outras três lavagens as lâminas foram montadas com conservador de fluorescência Vectashield (Vector, E.U.A.). As imagens foram adquiridas em microscópio confocal LSM 510 Meta (Zeiss, Alemanha). Os fluoróforos foram excitados em $488 \mathrm{~nm}$ (Alexa 488), $548 \mathrm{~nm}$ (Alexa 546) ou $350 \mathrm{~nm}$ (DAPI). Os dicroicos principais utilizados foram, respectivamente, UV/488, 477/573 e UV (375). A fluorescência foi coletada, respectivamente, com os filtros band-pass 501-587, 554-704 e 415-480. Utilizou-se uma objetiva plan-neofluar 100x com abertura numérica 1.3 para visualizar os parasitas.

\subsection{Lise de hemácias para isolamento de parasitas $P$. falciparum}

Hemácias parasitadas foram lavadas em PBS (5 min, $300 \mathrm{~g}$ ) e ressuspendidas em PBS contendo $0,3 \%(\mathrm{~m} / \mathrm{v})$ saponina e dos seguintes inibidores de proteases: benzamidina ( $400 \mu \mathrm{M}$, Sigma), antipaína, pepstatina A, leupeptina e quimostatina (Sigma, todos $20 \mu \mathrm{g} / \mathrm{mL}$ ). Após centrifugação a $13000 \mathrm{~g}$ durante $10 \mathrm{~min}, 4{ }^{\circ} \mathrm{C}$, as hemácias foram lavadas três vezes em tampão PBS com os inibidores de proteases nas concentrações indicadas acima (300 g, 5 $\min )$.

\subsection{Detecção de pfsr10 e pfsr25 em estágios intraeritrocíticos de $P$. falciparum através de western blot}

Parasitas $P$. falciparum (cepa 3D7) foram sincronizados diversas vezes. As sincronizações foram efetuadas de $48 \mathrm{~h}$ em $48 \mathrm{~h}$. A fase do parasita foi acompanhada através de coloração de Giemsa (Merck, E.U.A.). Alíquotas de parasitas foram isoladas através de lise com saponina em estágios jovens, intermediários e maduros do desenvolvimento. Parasitas isolados foram lisados em tampão de lise (1\% Triton X-100, $50 \mathrm{mM}$ Tris, $10 \%$ glicerol, $2 \mathrm{mM}$ EDTA, 2mM EGTA, pH 7,2) suplementado com benzamidina (400 $\mu \mathrm{M}$, Sigma), antipaína, pepstatina A, leupeptina, quimostatina (todos $20 \mu \mathrm{g} / \mathrm{mL}$, Sigma) e PMSF $1 \mathrm{mM}$ (Sigma). As 
amostras foram incubadas em gelo durante 20 min e centrifugadas a $13000 \mathrm{~g}$ durante $10 \mathrm{~min}$. A proteína foi quantificada através do método BCA (Pierce, E.U.A.). $50 \mu \mathrm{g}$ de proteína do sobrenadante foram fervidos em tampão de amostra de Laemmli durante $10 \mathrm{~min}$. As amostras foram corridas em gel de poliacrilamida $10 \% \mathrm{~m} / \mathrm{v}$ a $100 \mathrm{~V}$ em tampão de corrida (4M Tris, 1,92 M Glicina, 0,1\% SDS). A transferência para membrana de PVDF (Ge Healthcare, E.U.A.) foi executada a $300 \mathrm{~mA}$ durante $2 \mathrm{~h}$ em tampão contendo $3 \mathrm{~g} / \mathrm{L}$ Tris, $14,4 \mathrm{~g} / \mathrm{L}$ glicina, $20 \%$ metanol. O bloqueio foi executado overnight a $4{ }^{\circ} \mathrm{C}$ em TBST (Tris- $\mathrm{HCl} 20 \mathrm{mM}, \mathrm{NaCl}$ $150 \mathrm{mM}$, Tween-20 0,05\% v/v) contendo $5 \%(\mathrm{~m} / \mathrm{v})$ de leite desnatado. A incubação com anticorpo primário (anti-pfsr10 1:2000 ou anti-pfsr25 1:2000) foi executada a $4{ }^{\circ} \mathrm{C}$ durante 8 h sob agitação em TBST contendo 5\% (m/v) de albumina bovina (Sigma). Após três lavagens em TBST (10 min cada) a membrana foi incubada com anticorpo secundário conjugado a peroxidase 1:10000 (anti IgG rabbit HRP, Ge Healthcare) em TBST durante $1 \mathrm{~h}$ sob agitação, a temperatura ambiente. Após três lavagens (10 min cada) em TBST, a membrana foi revelada utilizando o kit ECL Plus (GE Healthcare). Para controle de carregamento no gel, os anticorpos foram removidos da membrana seguindo protocolo do fabricante e a membrana foi exposta a anticorpo anti-actina (1:5000, em TBST) desenvolvido em coelho (Sigma). Incubação com anticorpo secundário e revelação foram executadas conforme acima.

\subsection{Co-imunoprecipitação de parceiros moleculares dos receptores putativos pfsr10 e pfsr25 em $P$. falciparum}

A fase de parasitas $P$. falciparum (cepa 3D7) sincronizados foi acompanhada através de lâminas coradas pelo método de Giemsa (Merck). Parasitas nas fases de trofozoíto maduro e esquizonte foram isolados de hemácias.

Quando indicado, os parasitas isolados foram estimulados, em PBS, com $50 \mu \mathrm{M}$ de ATP durante 10 min. Os parasitas foram ressuspendidos em $2 \mathrm{~mL}$ tampão de lise de IP (1\% v/v Triton X-100, $50 \mathrm{mM}$ Tris $\mathrm{pH}$ 7.2, $150 \mathrm{mM} \mathrm{NaCl,} 10 \%$ v/v glicerol, $2 \mathrm{mM}$ EDTA, $2 \mathrm{mM}$ EGTA) contendo os inibidores de proteases benzamidina (4 mM), PMSF (1 mM), antipaína, pepstatina A, quimostatina e leupeptina (todos $200 \mu \mathrm{g} / \mathrm{mL}$ ) e os inibidores de fosfatases $\mathrm{NaF}$ $(1,8 \mathrm{mM})$ e ortovanadato de sódio $(6,7 \mathrm{mM})$. Os parasitas foram congelados overnight a -80 ${ }^{\circ} \mathrm{C}$. Após o descongelamento, os parasitas foram centrifugados a $13000 \mathrm{~g}$ durante $10 \mathrm{~min}, 4$ ${ }^{\circ} \mathrm{C}$. O sobrenadante foi incubado durante $30 \mathrm{~min}$ em agitador com $50 \mu \mathrm{L}$ de resina sefarose conjugada a proteína $\mathrm{A}$ (Ge Healthcare) com o intuito de retirar proteínas com afinidade à resina. Após centrifugação e retirada da resina, o sobrenadante foi incubado overnight com 20 
$\mu \mathrm{g}$ de anticorpo anti-pfsr10 ou anti-pfsr25 sob agitação a $4{ }^{\circ} \mathrm{C}$. O sobrenadante foi incubado durante $3 \mathrm{~h}$ com $50 \mu \mathrm{L}$ de resina ligada a proteína A. Após a incubação, a resina foi lavada uma vez com tampão de lavagem ( $\mathrm{LiCl} 500 \mathrm{mM}$, Tris-HCl $100 \mathrm{mM} \mathrm{pH} \mathrm{8.6)} \mathrm{para} \mathrm{reduzir}$ ligações inespecíficas e três vezes em PBS suplementado com inibidores de proteases antipaína, pepstatina A, quimostatina e leupeptina (todos $20 \mu \mathrm{g} / \mathrm{mL}$ ). O controle negativo passou pelos mesmos passos, com exceção da adição de anticorpos. Os beads foram incubados durante 10 min em tampão de Laemmli $(50 \mu \mathrm{L})$ e o sobrenadante foi submetido a SDS-PAGE. O gel foi fixado durante $1 \mathrm{~h}$ com solução de $50 \%$ etanol (v/v) e $10 \%$ ácido acético (v/v), lavado overnight com solução $50 \%$ (v/v) metanol, 10\% (v/v) ácido acético, corado durante $4 \mathrm{~h}$ sob agitação com Coomassie blue R350 (Merck) e descorado com solução $50 \%(\mathrm{v} / \mathrm{v})$ metanol e $10 \%(\mathrm{v} / \mathrm{v})$ ácido acético, sob agitação. As bandas de interesse foram recortadas do gel e as proteínas foram digeridas com tripsina e identificadas através de separação por cromatografia líquida e injeção em espectrômetros de massa em tandem. A digestão e identificação das proteínas através de espectrometria de massa foi executada pela Protein Core Facility da Universidade de Columbia (New York, E.U.A.), no caso dos tratamentos com ATP ou pela Taplin Biological Mass Spectrometry Faciliy da universidade de Harvard (Boston, E.U.A.). A análise dos resultados foi executada em programa Excel 2010 (Microsoft). Proteínas identificadas no controle negativo foram comparadas com proteínas encontradas na imunoprecipitação.

\subsection{Incubação de eritrócitos parasitados por esquizontes de $P$. falciparum com anticorpo anti-pfsr10 ou anti-pfsr25 e contagem de parasitemia}

Plasmodium falciparum (cepa 3D7) mantido em cultura e sincronizado diversas vezes com sorbitol foi incubado, na fase de esquizonte segmentado, com anticorpo anti-pfsr10 ou anti-pfsr25 em diversas concentrações. As hemácias infectadas (< 5\% parasitemia) foram pipetadas em placas ELISA de 24 wells, em um volume de meio RPMI 1640 (Gibco) de $1 \mathrm{~mL}$ e em um hematócrito de $2.5 \%$. A placa foi incubada durante $6 \mathrm{~h}$ a $37^{\circ} \mathrm{C}$ em câmara com mistura de gases $\left(90 \% \mathrm{~N}_{2}, 5 \% \mathrm{CO}_{2}, 5 \% \mathrm{O}_{2}\right)$ e, após adição de $10 \%(\mathrm{v} / \mathrm{v})$ de soro humano $\mathrm{A}^{+}$, a placa foi incubada durante $18 \mathrm{~h}$ adicionais sob as mesmas condições acima. As hemácias foram peletadas e lavadas uma vez com PBS (1 min, $300 \mathrm{~g}$ ), fixadas em solução $2 \%$ (v/v) formaldeído em PBS overnight a temperatura ambiente, lavadas uma vez com PBS (1 min, $300 \mathrm{~g}$ ), incubadas com RNAse A $0,5 \mathrm{mg} / \mathrm{mL}$ (Sigma) e Triton X-100 0,1\% (v/v) em PBS durante 30 min a $37{ }^{\circ} \mathrm{C}$, e expostas a $1 \mu \mathrm{M}$ de marcador de DNA YOYO-1 (Invitrogen). A 
contagem das células foi efetuada em citômetro FACScalibur (BD, E.U.A.). Hemácias infectadas formam um pico isolado de hemácias não infectadas, possibilitando o cálculo da parasitemia e estágios do parasita, conforme descrito em Schuck et al. (2011).

\subsection{Ensaios de dinâmica de cálcio em $P$. falciparum}

Parasitas $P$. falciparum (cepa 3D7) foram sincronizados. Aproximadamente 24 h após a sincronização, quando os parasitas se encontravam entre as fases de trofozoíto maduro e esquizonte jovem, a cultura foi coletada e os parasitas foram isolados através de lise com saponina. Os parasitas isolados foram lavados três vezes (13000 g, $5 \mathrm{~min}$ ) em tampão M (116 $\mathrm{mM} \mathrm{NaCl}, 5,4 \mathrm{mM} \mathrm{KCl}, 0,8 \mathrm{mM}$ MgSO4, 5,5 mM D-glicose, $50 \mathrm{mM}$ MOPS, $2 \mathrm{mM} \mathrm{CaCl}$, $\mathrm{pH}$ 7,2) e incubados durante $50 \mathrm{~min}$ a $37^{\circ} \mathrm{C}$ em tampão $\mathrm{M}$ com $5 \mu \mathrm{M}$ de Fluo-4 AM (Invitrogen) e $250 \mu \mathrm{M}$ de probenecida (Sigma). Parasitas foram lavados três vezes em tampão $\mathrm{M}$ contendo $250 \mu \mathrm{M}$ de probenecida. $3^{*} 10^{7}$ parasitas foram lavados em tampão $\mathrm{M}$ sem $\mathrm{KCl}$, com a molaridade acertada com $\mathrm{NaCl}$, contendo $\mathrm{CaCl}_{2}$, exceto em experimentos com EGTA (Sigma), nos quais $\mathrm{CaCl}_{2}$ foi suprimido do tampão. Alguns inibidores foram adicionados ao tampão, quando indicado, pouco antes do início do ensaio. A fluorescência do Fluo-4 AM foi monitorada em um espectrofluorímetro (RF5301PC Shimadzu, Japão). Fluo-4 AM foi excitado em $505 \mathrm{~nm}$ com a lâmada de Xe e a fluorescência emitida foi captada em $530 \mathrm{~nm}$, com frequência de $1 \mathrm{~Hz}$. A concentração de cálcio foi determinada usando a fórmula:

$$
[C a]=K d * \frac{(F-F \min )}{F \max -F}
$$

$[C a]$ é a concentração de cálcio, $F$ max é a fluorescência máxima obtida através da adição de digitonina (Merck) ao final do experimento, $F$ min é a fluorescência mínima obtida através da adição de EGTA, após a adição de digitonina, $F$ é a fluorescência em um dado momento e $K d$ é a constante de dissociação do Fluo-4 AM, considerada 345 nM. As drogas foram adicionadas utilizando seringas Hamilton (U. S. A.). O volume máximo de adição foi $10 \mu \mathrm{L}$. O volume do tampão no ensaio foi de $1 \mathrm{~mL}$. No caso de experimentos com cálcio extracelular quelado por EGTA, a concentração citosólica de cálcio não pôde ser calculada, e a fluorescência foi normalizada pela linha basal (média de 10 pontos da fluorescência basal). Nos experimentos com parasitas nocaute, a fluorescência foi normalizada pela linha basal para clareza de apresentação dos resultados. 


\subsection{Contagem de fases intraeritrocíticas e parasitemia de parasitas $P$. falciparum incubados com $\mathrm{KCl}$}

P. falciparum (cepa 3D7) foi mantido em cultura em parasitemia $<5 \%$. Parasitas foram sincronizados com sorbitol durante diversos ciclos. A fase do parasita foi seguida através de lâminas. Cultura contendo trofozoítos maduros e esquizontes jovens (por volta de 24 h após a sincronização) foi peletada a $300 \mathrm{~g}, 5$ min e o sobrenadante foi descartado. A cultura foi dividida em cinco partes. Cada parte foi ressuspendida em $10 \mathrm{~mL}$ de uma das seguintes soluções: RPMI 1640 (Gibco) sem soro (controle), tampão rico em $\mathrm{KCl}$ com $\mathrm{CaCl}_{2} 2 \mathrm{mM}$, tampão rico em $\mathrm{NaCl}$ com $\mathrm{CaCl}_{2} 2 \mathrm{mM}$, tampão rico em $\mathrm{KCl}$ com 2 mM EGTA ou tampão rico em $\mathrm{NaCl}$ com $2 \mathrm{mM}$ EGTA. A receita comum dos tampões foi: $5 \mathrm{mM} \mathrm{NaCl}, 1 \mathrm{mM}$ $\mathrm{MgCl}_{2}$, 5,6 mM D-glicose, $25 \mathrm{mM}$ HEPES-KOH, pH 7,2. Os tampões foram suplementados com $142 \mathrm{mM} \mathrm{NaCl}$ (tampão rico em sódio) ou $142 \mathrm{mM} \mathrm{KCl}$ (tampão rico em potássio). Após 30 min a $37^{\circ} \mathrm{C}$, os eritrócitos infectados foram centrifugados $(300 \mathrm{~g}, 5 \mathrm{~min}$ ) e ressuspendidos em RPMI 1640 suplementado com 10\% (v/v) de soro humano $\mathrm{A}^{+}$. A cultura foi transferida para uma placa ELISA estéril ( $1 \mathrm{~mL}$ por poço, cada tratamento foi dividido em quatro poços). A placa foi incubada em uma câmara em atmosfera de $5 \% \mathrm{CO}_{2}, 5 \% \mathrm{O}_{2}$, e $80 \% \mathrm{~N}_{2}$, a $37{ }^{\circ} \mathrm{C}$, durante 6 h. Lâminas foram montadas e coradas para contagem de fases em microscópio de luz, contando ao menos 1000 eritrócitos. Apenas as fases intraeritrocíticas de esquizonte e anel foram analisadas, já que trofozoítos foram encontrados em porcentagens baixas no experimento. A fim de contar parasitemia, foi utilizado um citômetro (FACS calibur, BD), seguindo um protocolo descrito anteriormente (Schuck et al., 2011). Os dados foram normalizados pela média do controle (RPMI) e analisados estatisticamente utilizando OneWay ANOVA com pós-teste de Newman Keuls no programa GraphPad Prism v 4.03. Significância estatística foi considerada para $\mathrm{p}<0.05$. Foram executados três experimentos independentes.

\subsection{Transfecção e ensaios de dinâmica de cálcio em células 1321N1}

Células 1321N1 foram transfectadas utilizando o eletroporador Microporator (Invitrogen), seguindo o protocolo do fabricante e utilizando o programa 17 (850V, $20 \mathrm{~ms}, 2$ pulsos). Células foram cotransfectadas com pcDNA3.1(-)-PFSR10 e/ou pcDNA3.1(-)G $\alpha_{15}$ e/ou plasmídeo vazio e plasmídeo codificante de aequorina citosólica (Brini, 2008), nas combinações indicadas. As quantidades de DNA utilizadas foram de 0,5 $\mu \mathrm{g}$ (aequorina 
citossólica), e $2 \mu \mathrm{g}$, no total, dos demais plasmídeos. (i.e., para cotransfecção de PFSR10 e $\mathrm{Ga}_{15}$, foi utilizado $1 \mu \mathrm{g}$ de cada plasmídeo; para transfecção de apenas plasmídeo vazio, foram utilizados $2 \mu \mathrm{g}$ do plasmídeo; para transfecção de PFSR10, foi utilizado $1 \mu \mathrm{g}$ de PFSR10 e $1 \mu \mathrm{g}$ de plasmídeo vazio). Portanto, as quantidades de DNA foram mantidas constantes entre as transfecções.

Experimentos de dinâmica de cálcio foram executados em um luminômetro, 24 h após a transfecção, conforme descrito em Brini (2008).

\subsection{Transfecção de células HEK293T}

Células embrionárias de rim humanas expressando o antígeno T (HEK293T) foram plaqueadas em garrafas de cultura de $25 \mathrm{~cm}^{2}$ e crescidas com meio DMEM rico em glicose (Gibco) com soro fetal bovino $10 \%$ e estreptomicina/penicilina em estufa de $\mathrm{CO}_{2}$ a $37^{\circ} \mathrm{C}$ durante $24 \mathrm{~h}$. As células, com 90\% de confluência, foram transfectadas com Lipofectamina $2000(20 \mu \mathrm{L} / 8 \mu \mathrm{g}$ de DNA, Invitrogen) segundo o protocolo do fabricante e utilizando DMEM sem soro e sem antibióticos.

Para ensaios com pfsr10, as transfecções foram executadas com $8 \mu \mathrm{g}$ de pcDNA 3.1 () ou $8 \mu \mathrm{g}$ pcDNA 3.1 (-)-PFSR10 ou $4 \mu \mathrm{g}$ de pcDNA3.1(-)-G $\alpha_{15}$ e $4 \mu \mathrm{g}$ de pcDNA 3.1 (-)PFSR10 ou $4 \mu \mathrm{g}$ de pcDNA3.1(-)-G $\alpha_{15}$ e $4 \mu \mathrm{g}$ de pcDNA 3.1 (-). Para ensaios com pfsr25, foram utilizados $8 \mu \mathrm{g}$ pcDNA3.1(-) ou $8 \mu \mathrm{g}$ pcDNA 3.1 (-)-PFSR25. Após $6 \mathrm{~h}$ de incubação em estufa de $\mathrm{CO}_{2}$ a $37{ }^{\circ} \mathrm{C}$ o meio foi trocado por DMEM contendo $10 \% \mathrm{v} / \mathrm{v}$ de soro fetal bovino.

\subsection{Ensaios de dinâmica de cálcio em células HEK293T transfectadas com pcDNA3.1- PFSR10 ou pcDNA3.1-PFSR25}

Após 24 h de transfecção, as células foram tripsinizadas e contadas utilizando câmara de Neubauer. As células transfectadas foram crescidas durante mais $24 \mathrm{~h}$ em placas de 96 poços pretas com fundo transparente (Costar, E.U.A.) em meio DMEM com 10\% v/v soro fetal bovino $\left(100 \mu \mathrm{L}\right.$ de meio por poço, $3^{*} 10^{4}$ células por poço). $\mathrm{O}$ meio foi retirado e as células marcadas com $40 \mu \mathrm{L}$ de DMEM $10 \%$ v/v soro fetal bovino contendo $5 \mu \mathrm{M}$ Fluo-4 $\mathrm{AM}$ (Invitrogen) durante $1 \mathrm{~h}$ a $37^{\circ} \mathrm{C}$ em estufa de $\mathrm{CO}_{2}$. As células foram lavadas duas vezes com HBSS $\left(5,4 \mathrm{mM} \mathrm{KCl}, 0,3 \mathrm{mM} \mathrm{Na} 2 \mathrm{PO}_{4}, 0,4 \mathrm{mM} \mathrm{KH}{ }_{2} \mathrm{PO}_{4}, 4,2 \mathrm{mM} \mathrm{NaHCO} 3,0,5 \mathrm{mM}\right.$ 
$\mathrm{MgCl}_{2}, 0,6 \mathrm{mM} \mathrm{MgSO}$, 5,6 mM D-glucose, 136,9 mM NaCl) contendo $\mathrm{CaCl}_{2} 2 \mathrm{mM}$ (200 $\mu \mathrm{L}$ /poço). Após as lavagens, foi adicionado um volume de $190 \mu \mathrm{L}$ de HBSS contendo inibidores, quando indicado. A leitura e adição de drogas foi feita em sistema Flexstation 3 (Molecular Devices, E.U.A.), utilizando o modo Flex, excitando o marcador Fluo-4 AM em $488 \mathrm{~nm}$ e coletando a fluorescência em $525 \mathrm{~nm}$. Foi utilizado um espelho dicróico de barragem da fluorescência de excitação em $515 \mathrm{~nm}$. Foi tomada uma linha de base durante 50 segundos. Após esse tempo, $10 \mu \mathrm{L}$ da droga 20 vezes concentrada foi adicionada e a fluorescência foi registrada durante mais 225 segundos. Os gráficos foram reduzidos através do programa SoftMax Pro 5.2 de maneira que a linha basal fosse 100\%, após smoothing do gráfico utilizando a média de nove pontos. Os dados de três experimentos independentes foram normalizados pelo controle (transfectado com pcDNA3.1(-) ou pcDNA3.1(-)-G $\alpha_{15}$ ). A resposta (Fluorescência Maxima - Flurescência Basal) foi comparada por One-Way ANOVA com pós-teste de Newman Keuls através do programa GraphPad Prism 4.03. Diferença significativa foi considerada para $\mathrm{p}<0,05$.

\subsection{Crescimento de células HEK293T}

Células HEK293T foram cotransfectadas com os plasmídeos conforme indicado para os experimentos de dinâmica de cálcio. Células foram plaqueadas em placas de ELISA de 24 poços e contadas em câmara de Neubauer após crescimento.

\subsection{Experimentos de fosforilação em células HEK 293T transfectadas com pcDNA3.1(- )-PFSR10 e pcDNA3.1(-)-Ga 15}

Células HEK293T transfectadas com pcDNA3.1(-) e pcDNA3.1(-)-G $\alpha_{15}$ ou pcDNA3.1(-)-PFSR10 e pcDNA3.1(-)-G $\alpha_{15}$ foram tripsinizadas e divididas em 8 placas de Petri de $100 \mathrm{~mm}$ de diâmetro (Corning), sendo 4 placas de células transfectadas com pcDNA3.1(-) e $\mathrm{G} \alpha_{15}$ e 4 placas de células transfectadas com PFSR10 e G $\alpha_{15}$. Após cultivo em DMEM contendo $10 \%$ de soro fetal bovino durante $24 \mathrm{~h}$, as células foram cultivadas durante mais $24 \mathrm{~h}$ em DMEM sem soro fetal bovino (carenciamento). Após troca do meio por DMEM sem soro ( $5 \mathrm{~mL}$ por placa), as células foram estimuladas com ATP $100 \mathrm{nM}$, ATP $1 \mu \mathrm{M}$, ATP $50 \mu \mathrm{M}$ (Sigma) e incubadas durante $10 \mathrm{~min}$ a $37^{\circ} \mathrm{C}$. Algumas células não foram estimuladas e também foram incubadas $10 \mathrm{~min}$ a $37^{\circ} \mathrm{C}$. As células foram lavadas três vezes em PBS gelado imediatamente após o estímulo e raspadas em $500 \mu \mathrm{L}$ de tampão de lise (Tris $50 \mathrm{mM}$, 
5 mM EGTA, 5 mM EDTA, $150 \mathrm{mM} \mathrm{NaCl}$, 0,5\% Triton X-100, $10 \%$ glicerol, pH 8,0) contendo os inibidores de proteases antipaína, pepstatina, quimostatina e leupeptina nas concentrações de $20 \mu \mathrm{g} / \mathrm{mL}$ cada, $400 \mu \mathrm{M}$ de benzamidina e $1 \mathrm{mM}$ de PMSF e também os inibidores de fosfatases ortovanadato de sódio $(1 \mathrm{mM})$ e fluoreto de sódio $(1 \mathrm{mM})$. Após repouso no gelo durante $20 \mathrm{~min}$, os lisados foram centrifugados durante 10 min a $13000 \mathrm{~g}$, o sobrenadante separado e as proteínas quantificadas pelo método BCA. $50 \mu \mathrm{g}$ de proteína do sobrenadante de cada amostra foram fervidas durante 10 min a $100{ }^{\circ} \mathrm{C}$ em tampão de amostra de Laemmli, aplicada em gel de poliacrilamida $10 \%$ e corrida a $80 \mathrm{~V}$ em tampão contendo SDS. As proteínas do gel foram transferidas para membranas de PVDF a $300 \mathrm{~mA}$ durante $2 \mathrm{~h}$ e a membrana bloqueada $2 \mathrm{~h}$ em TBST 5\% leite desnatado (m/v) à temperatura ambiente. As membranas foram incubadas em TBST contendo 5\% leite desnatado com um dos seguintes anticorpos primários: anti-fosfotirosina (539236, Calbiochem, E.U.A.) ou anti-fosfoserina (KP30601, Calbiochem, U.S.A.) overnight a $4{ }^{\circ} \mathrm{C}$ no mesmo tampão acima. Após 3 lavagens de 5 min cada em TBST, as membranas foram incubadas com os anticorpos secundários antiIgG mouse HRP 1:10000 (no caso de membranas incubadas com anti-fosfoserina) ou anti-IgG rabbit HRP 1:10000 (no caso de membranas incubadas com anti-fosfotirosina) durante $1 \mathrm{~h} \mathrm{em}$ TBST 5\% de leite desnatado. Após 3 lavagens de 5 min cada em TBST, as membranas foram reveladas com o kit ECL Plus (Ge Healthcare). Os anticorpos foram retirados das membranas através de incubação a $50{ }^{\circ} \mathrm{C}$ durante $30 \mathrm{~min}$ em tampão $100 \mathrm{mM}$ 2-mercaptoetanol, $2 \%$ SDS (m/v), 62,5 mM Tris $\mathrm{HCl}$ pH 6,7. Após sucessivas lavagens com TBST, as membranas foram bloqueadas overnight e incubadas com anticorpo anti-actina desenvolvido em coelho (Sigma) 1:2000, durante 4 h em TBST 5\% leite desnatado. Após 3 lavagens em TBST, com duração de 5 min cada, as membranas foram incubadas com anticorpo secundário anti-IgG mouse HRP 1:10000 em TBST durante $1 \mathrm{~h}$. Após três lavagens de 5 min cada em TBST as membranas foram reveladas com o kit ECL plus (Ge Healthcare). Os experimentos de fosforilação foram repetidos três vezes para anti-fosfotirosina e três vezes para antifosfoserina. Bandas em alturas diferentes das membranas que apareceram nos três experimentos foram selecionadas para quantificação com a utilização do programa Scion Image (Scion Corporation, E.U.A.), plugin gelplot2. As intensidades das bandas de fosforilação foram normalizadas pelas intensidades das bandas de actina para cada linha do gel. Foram utilizadas exposições menores da membrana para normalizar bandas muito intensas. Os valores assim obtidos foram normalizados pelos respectivos controles (i.e., proteína proveniente de tratamento com ATP de células transfectadas com PFSR10 e G $\alpha_{15}$ normalizada por proteína sem tratamento com ATP de células transfectadas com PFSR10 e 
$\mathrm{G} \alpha_{15}$ e proteína proveniente do tratamento com ATP de células transfectadas com pcDNA3.1(-) e $\mathrm{G} \alpha_{15}$ normalizada por proteína sem tratamento com ATP de células transfectadas com pcDNA3.1(-) e $G \alpha_{15}$ ). Para verificar se a fosforilação basal era diferente entre células transfectadas com pcDNA3.1(-) e G⿰ $\alpha_{15}$ e células transfectadas com PFSR10 e $\mathrm{G}_{15}$, dividimos a intensidade das bandas normalizadas da transfecção de PFSR10 e G $\alpha_{15}$ pela intensidade das bandas normalizadas da transfecção de pcDNA3.1(-) e $G \alpha_{15}$ das transfecções não tratadas com ATP.

Os dados foram plotados em gráficos no programa GraphPad Prism versão 4.03 e analisados pelo teste t não pareado, comparando as duas condições de transfecção entre si para um mesmo tratamento (i.e., controle sem ATP, ATP $100 \mathrm{nM}$, ATP $1 \mu \mathrm{M}$ e ATP $50 \mu \mathrm{M}$ ). Valores significativamente diferentes foram considerados para $\mathrm{p}<0,05$.

Para verificar o estado de fosforilação das proteínas ERK1/2 em células HEK293T transfectadas com pfsr10, a membrana foi incubada overnight a $4{ }^{\circ} \mathrm{C}$ com anti-ERK $1 / 2$ fosforilada (p44/p42 MAPK, 9102, Cell Signaling, E.U.A.) na diluição 1:2000 em TBST 5\% BSA. Após três lavagens em TBST, 10 min cada, a membrana foi incubada durante $1 \mathrm{~h}$ em TBST com anti rabbit HRP 1:10000 (GE Healthcare). Após três lavagens com TBST (10 min cada), a membrana foi revelada com o kit ECL Plus (GE Healthcare).

Para incubação com o anticorpo que reconhece ERK 1/2 total (p44/p42 MAPK, 9101 Cell Signaling), os anticorpos foram removidos da membrana PVDF através de protocolo do fabricante (GE Healthcare). A membrana foi bloqueada e incubada com anticorpo primário anti ERK 1/2 total nas mesmas condições acima. A incubação com anticorpo secundário e revelação foram efetuadas conforme as condições descritas acima.

\subsection{Detecção da expressão de pfsr10 e pfsr25 em linhagens de células de mamíferos transfectadas através de imunofluorescência}

Células HEK293T foram transfectadas com pcDNA3.1(-)-PFSR10 ou pcDNA3.1(-)PFSR25 foram crescidas em placas de microscopia confocal (Mattek, U.S.A.) durante $48 \mathrm{~h}$. Células foram incubadas com $10 \mu \mathrm{g} / \mathrm{mL}$ de aglutinina conjugada a Alexa Fluor 594 (WGAAlexa 594, Invitrogen) em HBSS com $2 \mathrm{mM} \mathrm{CaCl}_{2}$ durante 10 min a $37^{\circ} \mathrm{C}$. As células foram fixadas com 4\% de paraformaldeído, 20\% de sacarose em PBS durante 15 min a temperatura ambiente, lavadas em PBS três vezes e incubadas em solução de quenching contendo $0,15 \%$ de glicina $(\mathrm{m} / \mathrm{v})$ e $0,24 \%$ de $\mathrm{NH}_{4} \mathrm{Cl}(\mathrm{m} / \mathrm{v})$ durante $20 \mathrm{~min}$. As células foram permeabilizadas com $0,1 \%$ de Triton X-100 (Merck) em PBS durante 3 min. Após 30 min de incubação em 
solução de bloqueio contendo $10 \%$ soro equino, $5 \%$ BSA e $0,05 \%$ de gelatina, as células foram lavadas duas vezes com $500 \mu \mathrm{L}$ de PBS e incubadas com anticorpo anti-FLAG (Sigma) 1:500 (camundongo) em solução de bloqueio durante 1 h. Após 3 lavagens em PBS, as células foram incubadas com o anticorpo secundário anti-IgG de camundongo acoplado a Alexa Fluor 488 1:300 (Invitrogen) em solução de bloqueio durante $1 \mathrm{~h}$ à temperatura ambiente. As células foram lavadas com PBS 3 vezes e incubadas com DAPI 0,01 mg/mL por $10 \mathrm{~min}$ em PBS. As células foram lavadas duas vezes com PBS durante 5 min e analisadas em microscópio confocal Carl Zeiss LSM 510 Meta (Alemanha), de maneira similar à descrita para imunofluorescência de parasitas $P$. falciparum. Para células $1321 \mathrm{~N} 1$, o protocolo de imunofluorescência foi essencialmente o mesmo, com a diferença de que DAPI e aglutinina não foram utilizados.

\subsection{Detecção da expressão de pfsr10 e pfsr25 em células HEK293T transfectadas através de imunoprecipitação seguida de western blot}

Células HEK293T foram transfectadas com pcDNA3.1(-)-PFSR10 ou pcDNA3.1(-)PFSR25 conforme descrito para experimentos de dinâmica de cálcio. As células foram lisadas em tampão de lise (Tris-HCl 50 mM, pH 7.2, NaCl 150 mM, Triton X-100 1\%, glicerol 10\%, EDTA $2 \mathrm{mM}$, EGTA $2 \mathrm{mM}$, pepstatina $20 \mu \mathrm{g} / \mathrm{mL}$, leupeptina $20 \mu \mathrm{g} / \mathrm{mL}$, quimostatina 20 $\mu \mathrm{g} / \mathrm{mL}$, antipaína $20 \mu \mathrm{g} / \mathrm{mL}$, PMSF (Sigma) 0,2 mM, ortovanadato de sódio $1 \mathrm{mM}$, fluoreto de sódio $5 \mathrm{mM}$ ) por $30 \mathrm{~min}$ a $4{ }^{\circ} \mathrm{C}$. O lisado celular foi centrifugado a $13000 \mathrm{~g}$ por $30 \mathrm{~min} .50 \mu \mathrm{l}$ de proteína A/G (Ge Healthcare) $50 \%$ (v/v) foi adicionado e incubado por 30 min a $4^{\circ} \mathrm{C}$. O sobrenadante foi coletado e quantificado pelo método de Bradford. A aproximadamente 2,5 mg de proteína, adicionou-se $40 \mu \mathrm{l}$ de anti-flag M2 conjugado a proteína G (Sigma). As amostras foram mantidas a $4{ }^{\circ} \mathrm{C}$ sob agitação por $16 \mathrm{~h}$. Em seguida, as amostras foram lavadas 1 vez com tampão de lavagem ( $\mathrm{LiCl} 500 \mathrm{mM}$, Tris-HCl 100mM pH8.6), seguida por 3 lavagens com PBS por 2 min a $300 \mathrm{~g}$. As amostras foram ressuspendidas em tampão de amostra 2 vezes (100 mM Tris-HCl pH 6,8, 4\% (m/v) SDS, 20\% (v/v) glicerol, $2 \%(\mathrm{v} / \mathrm{v}) \beta-$ mercaptoetanol, $25 \mathrm{mM}$ EDTA, 0,04\% (m/v) azul de bromofenol). Proteínas foram separadas em 10\% SDS-PAGE sob condições redutoras e transferidas para membrana de PVDF (GE Healthcare). A membrana foi bloqueada por $1 \mathrm{~h}$ a temperatura ambiente em TBST contendo 5\% (v/v) leite desnatado (Tris- $\mathrm{HCl} 20$ mM, NaCl 150 mM, Tween 20 0,01\%, pH 7,4). A membrana foi incubada por $2 \mathrm{~h}$ a temperatura ambiente com anticorpo monoclonal antiFLAG M2 (Sigma) diluído 1:5000 em TBS-T contendo 5\% (v/v) de leite desnatado ou 
overnight a $4^{\circ} \mathrm{C}$ com anticorpo específico anti-pfsr10 1:2000 em TBST contendo 5\% (v/v) de leite desnatado. A membrana foi lavada 3 vezes, 15 min cada lavagem, em TBST e incubada por $1 \mathrm{~h}$ com anticorpo anti-IgG camundongo/coelho conjugado a HPR (Ge Healthcare). Após lavagem três vezes, 15 min cada, com TBST, a atividade de peroxidase foi detectada pela técnica de ECL (Ge Healthcare). 


\section{RESULTADOS}

\subsection{Receptor Serpentino putativo PFSR10}

\subsubsection{Expressão proteica e localização de pfsr10 em fases sanguíneas de Plasmodium falciparum: o receptor putativo é expresso em todas as fases do ciclo intraeritrocítico e transita pela via de exportação proteica}

Com a finalidade de verificar a presença de pfsr10 ao longo do ciclo intraeritrocítico utilizamos a técnica de western blot. Em parasitas sincronizados e isolados, demonstramos a expressão de pfsr10 nas fases de anel, trofozoíto e esquizonte (Figura 7 A). O anticorpo reconheceu, nas três fases intraeritrocíticas, uma única banda de aproximadamente $80 \mathrm{kDa}$, que está próximo do peso molecular predito da proteína (aproximadamente $78 \mathrm{kDa}$ ). Interessantemente, quando efetuamos o western blot em condições não redutoras, verifica-se que o anticorpo reconhece bandas de alto peso molecular (Figura 7 B).

A fim de verificar colocalização de pfsr10 com a membrana plasmática do parasita, utilizamos marcação conjunta de pfsr10 e anti-msp1, uma proteína de superfície de merozoíto (Figura 8, Figura 9). Verificamos, assim, que pfsr10 possui forte colocalização com a membrana em merozoítos e anéis (Figura 8), porém não em esquizontes jovens e esquizontes maduros (Figura 9).

Em trofozoítos, msp1 e pfsr10 não colocalizam, porém msp1 parece estar localizada ao redor do vacúolo digestivo nessa fase (Figura 9). Assim, a partir desses dados, não podemos determinar a localização de pfsr10 em trofozoítos, apesar de ser pouco provável que pfsr10 possua forte localização com a membrana plasmática nessa fase uma vez que o padrão de fluorescência é citoplasmático.

A fim de verificar se havia reação cruzada entre anticorpos primários e anticorpos secundários, anti-msp1 (camundongo) foi incubado com anti-IgG de coelho ligado a Alexa 488. Em outra incubação, anti-pfsr10 (coelho) foi incubado com anti-IgG de camundongo ligado a Alexa 546. Em ambos os casos, não foi observada fluorescência nos parasitas (dados não mostrados). 
Figura 7 - Detecção de pfsr10 em P. falciparum através de western blot.

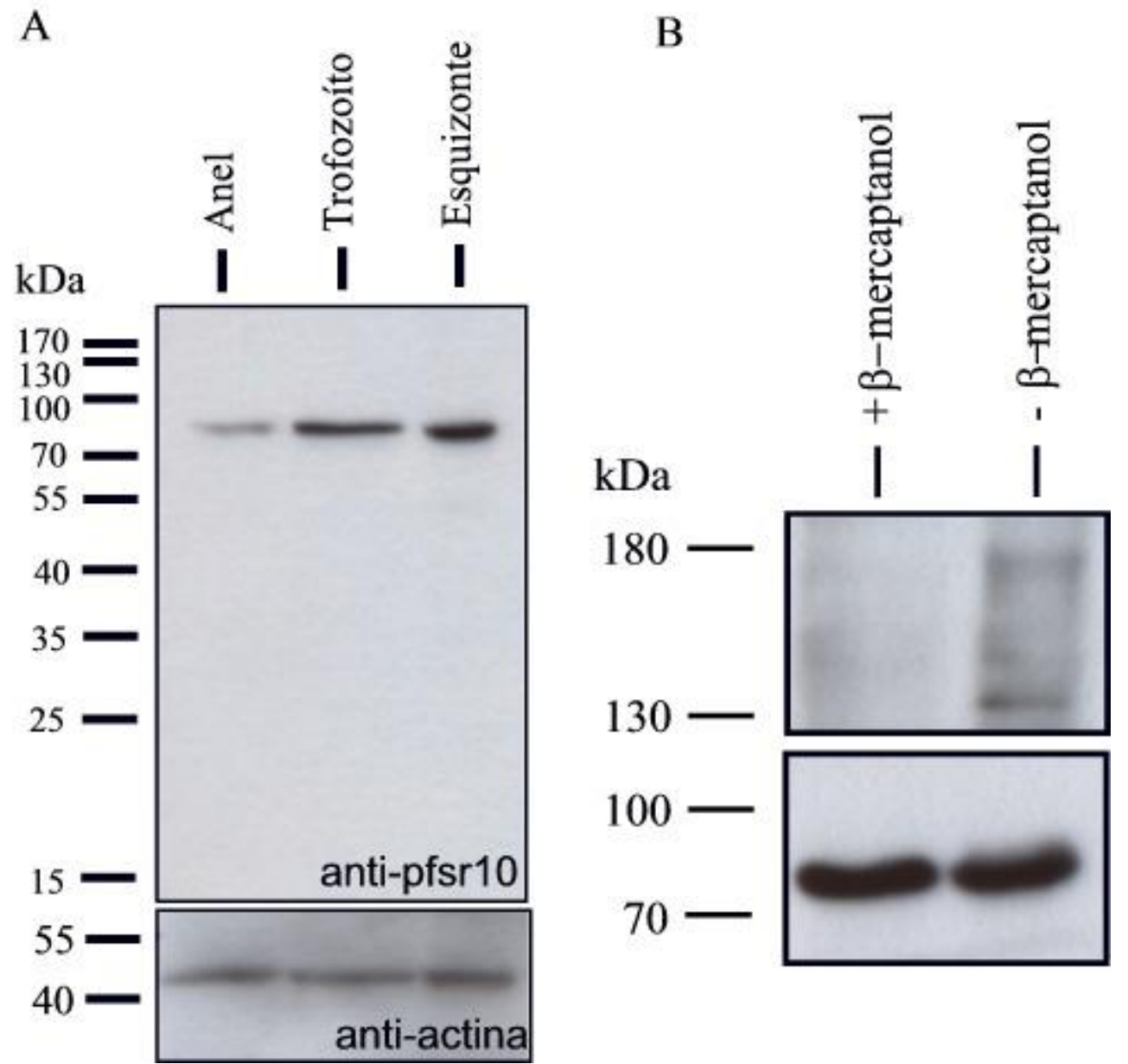

A: Deteç̧ão de pfsr10 em fases do ciclo intraeritrocitico de P. falciparum. Parasitas isolados de $P$. falciparum, sincronizados nas fases de anel, trofozoíto e esquizonte foram lisados e a proteína das amostras foi quantificada. Após SDS-PAGE, transferência para membrana de PVDF e bloqueio, a membrana foi incubada com anti-pfsr10 de coelho (1:2000) e anti- IgG de coelho conjugado a HRP. O controle de carregamento de proteína no gel foi efetuado com anti-actina (1:5000). B: Detecção de oligômeros envolvendo pfsr10 em P. falciparum. Extratos protéicos de parasitas dessincronizados foram incubados com o agente redutor de pontes dissulfeto $\beta$-mercaptoetanol $(+\beta$-mercaptoetanol) ou na ausência do agente redutor (- $\beta$-mercaptoetanol). Western blot foi executado da mesma maneira que em $\mathbf{A}$.

Em experimentos de imunofluorescência o anticorpo anti-pfsr10 marca diferentes fases sanguíneas do parasita, conforme demonstrado pela marcação conjunta com DAPI (Figura 8, Figura 9). Nas fases de merozoíto e anel, a localização de pfsr10 é periférica (Figura 8), ao passo que a partir da fase de trofozoíto, esquizonte jovem e esquizonte maduro a marcação de pfsr10 é mais internalizada (Figura 9). 
Figura 8 - Localização subcelular de pfsr10 em fases jovens de $P$. falciparum.

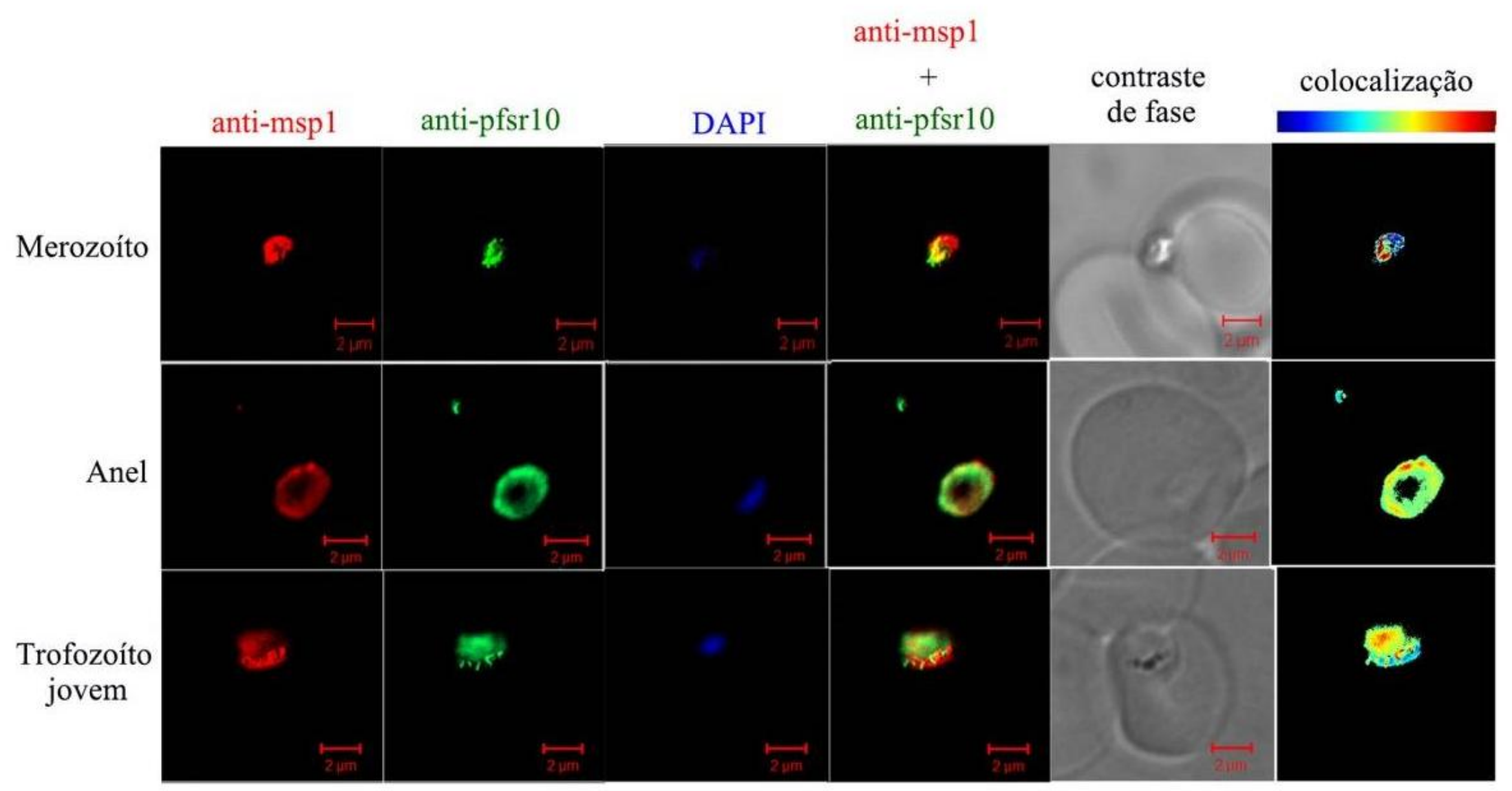

Hemácias infectadas fixadas e bloqueadas foram incubadas com anti-pfsr10 desenvolvido em coelho (1:250), anti-msp1 desenvolvido em camundongo (1:50) e anticorpos secundários anti-IgG de coelho ligado a Alexa 488 e anti-IgG de camundongo ligado a Alexa 546. Colocalização entre msp1 e pfsr10 foi analisada com programa ImageJ, plugin colocalization Colormap. Cores próximas ao vermelho indicam boa colocalização (barra). Para diferenciar fases intraeritrocíticas, o DNA dos parasitas foi marcado com DAPI. 
Figura 9 - Localização subcelular de pfsr10 em fases maduras de P. falciparum.

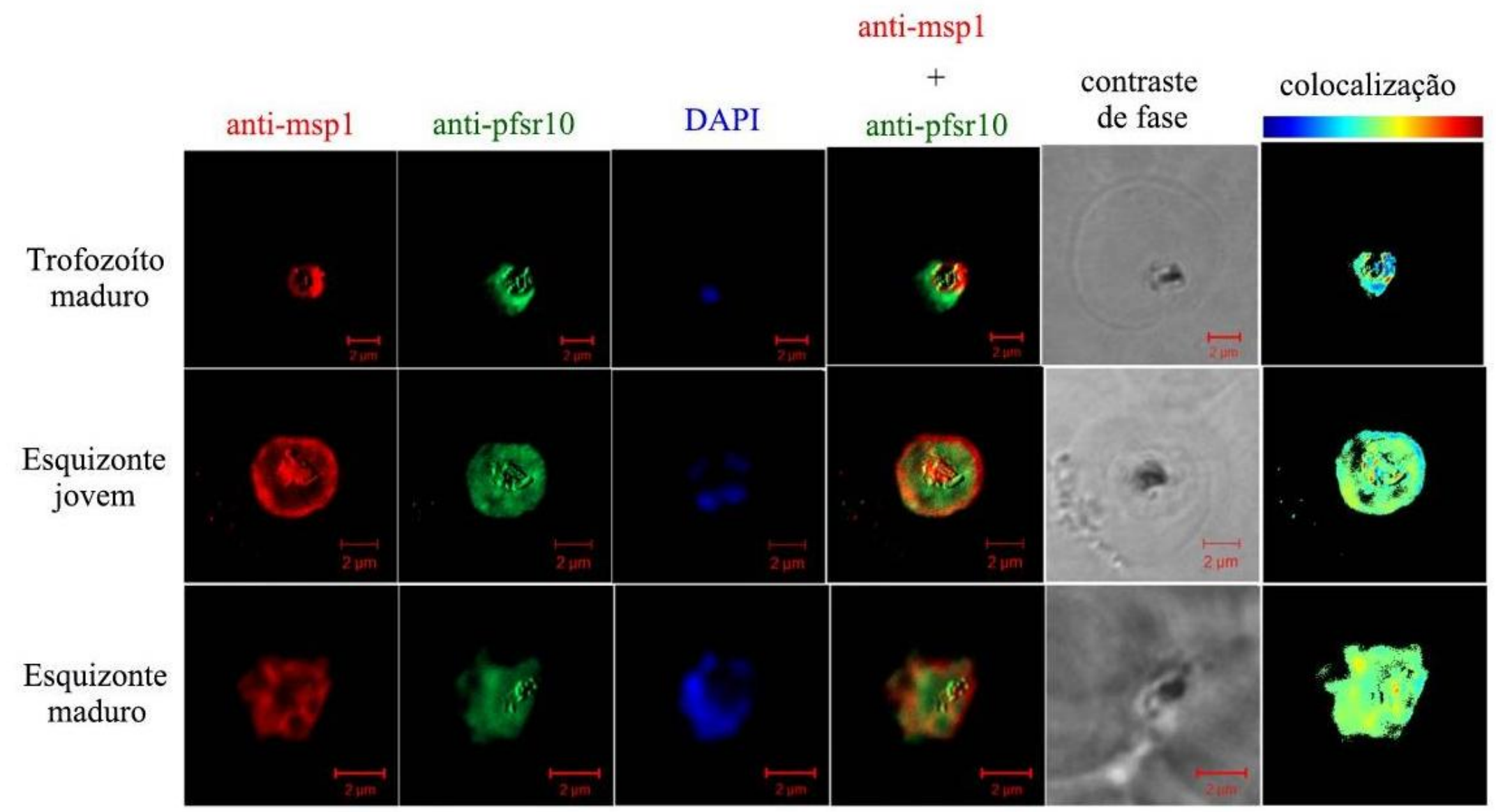

Hemácias infectadas fixadas e bloqueadas foram incubadas com anti-pfsr10 desenvolvido em coelho (1:250), anti-msp1 desenvolvido em camundongo (1:50) e anticorpos secundários anti-IgG de coelho ligado a Alexa 488 e anti-IgG de camundongo ligado a Alexa 546. Colocalização entre msp1 e pfsr10 foi analisada com programa ImageJ, plugin colocalization Colormap. Cores próximas ao vermelho indicam boa colocalização (barra). Para diferenciar fases intraeritrocíticas, o DNA dos parasitas foi marcado com DAPI. 
A especificidade do anticorpo anti-pfsr10 pelo epítopo é demonstrada pela ausência de marcação no parasita quando se adiciona o peptídeo utilizado para a síntese do anticorpo durante a incubação com anticorpo primário (Figura 10).

Figura 10 - Controle de especificidade do anticorpo anti-pfsr10 nos ensaios de imunofluorescência.

$$
\text { anti-pfsr10 + DAPI }
$$

$$
\begin{array}{r}
\text { anti-pfsr10 + DAPI } \\
\text { epitopo } 20 \mu \mathrm{g} / \mathrm{mL}
\end{array}
$$
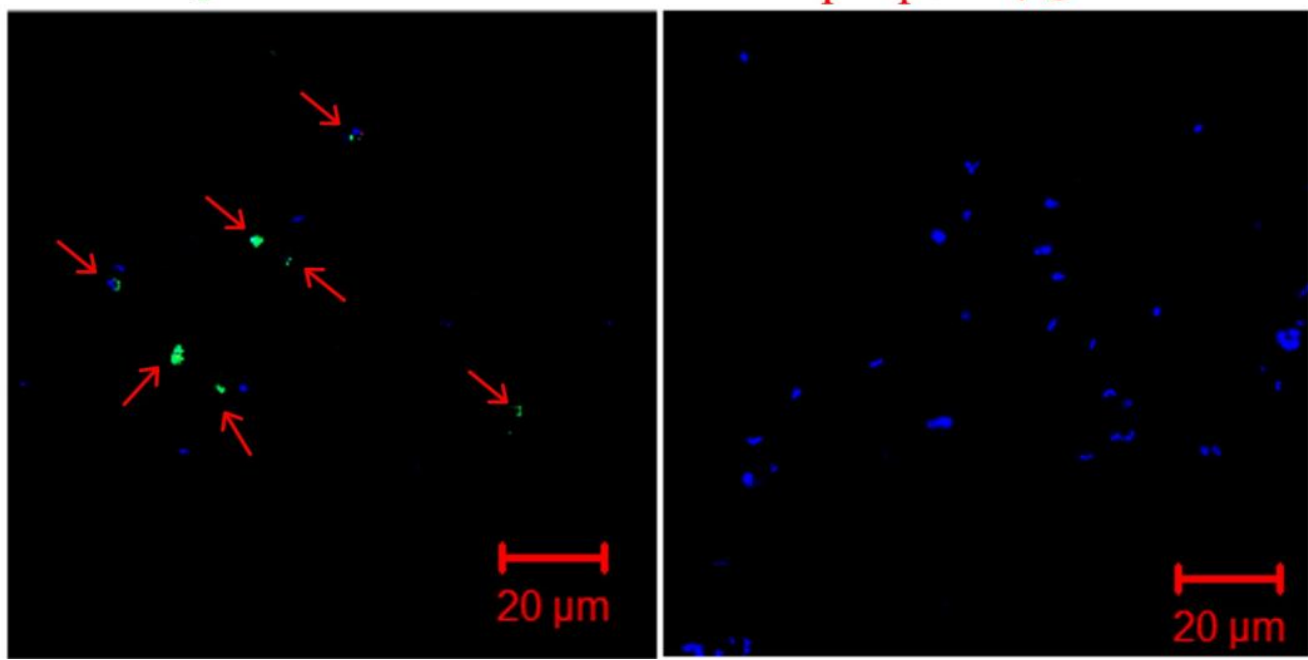

Hemácias infectadas fixadas e bloqueadas foram incubadas com anti-pfsr10 (1:250) e anticorpo secundário apropriado (anti-IgG rabbit conjugado a Alexa 488, 1:300, em verde na figura). Uma parte das hemácias infectadas fixadas foram incubadas com anticorpos na presença de peptídeo utilizado como antígeno para desenvolver o anticorpo anti-pfsr10. DNA foi marcado com DAPI (em azul na figura). Setas apontam parasitas em que foi detectada fluorescência verde, indicativa de reconhecimento de pfsr10 pelo anticorpo anti-pfsr10.

Tendo em vista que pfsr10 colocaliza com a membrana plasmática na fase de anel, resolvemos verificar se a proteína entra na via exocítica. Assim, utilizamos um inibidor de transporte entre o retículo endoplasmático e o complexo de Golgi, Brefeldina A. Ao incubarmos o parasita com o inibidor verificamos que a distribuição de pfsr10 é grandemente alterada, passando de uma distribuição periférica no parasita para uma localização pontual (Figura 11). 
Figura 11 - Efeito da brefeldina A na localização subcelular de pfsr10.

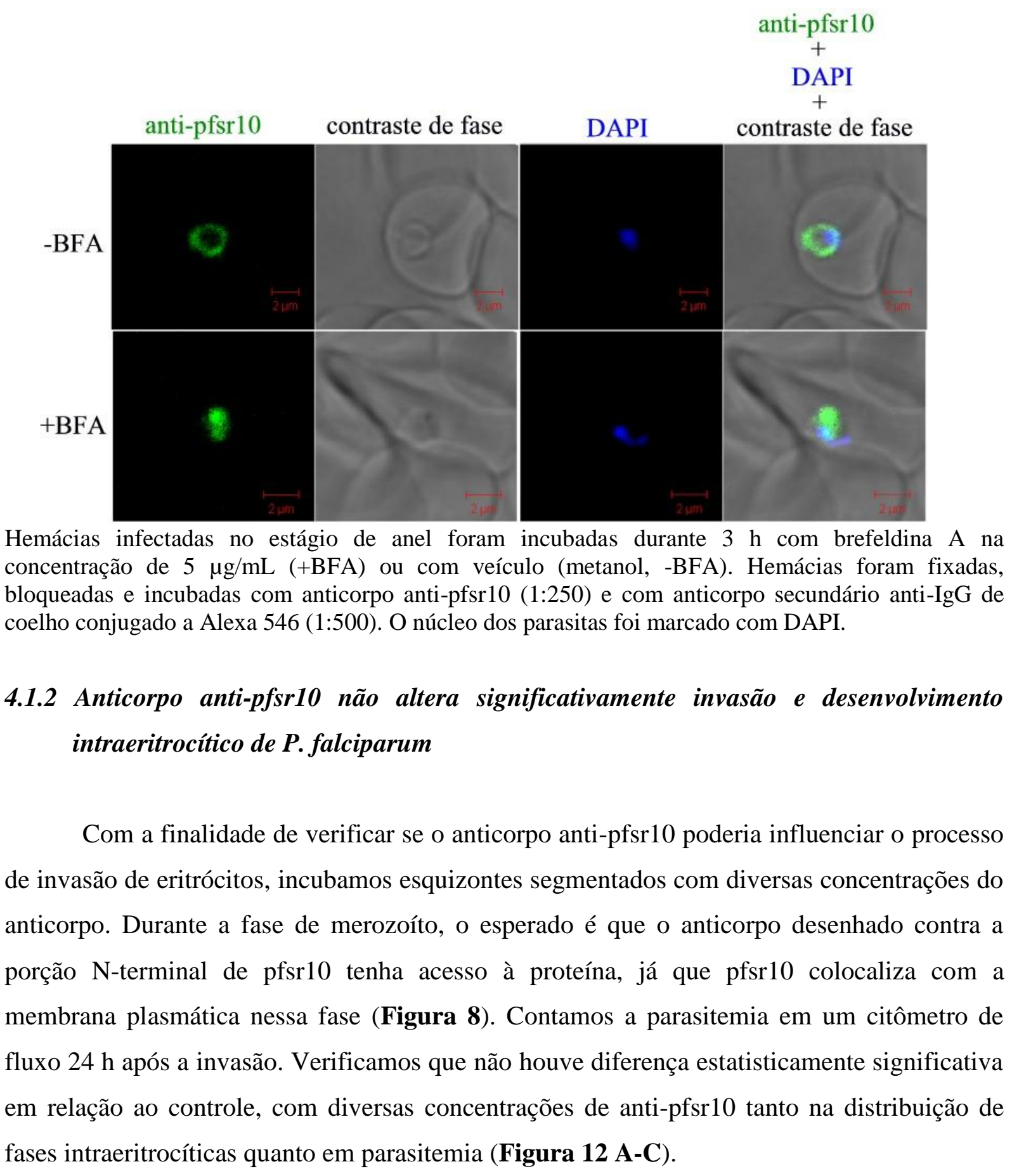


Figura 12 - Distribuição de fases e parasitemia após invasão de hemácias por $P$. falciparum em presença de diversas concentrações de anticorpo anti-pfsr 10.

A
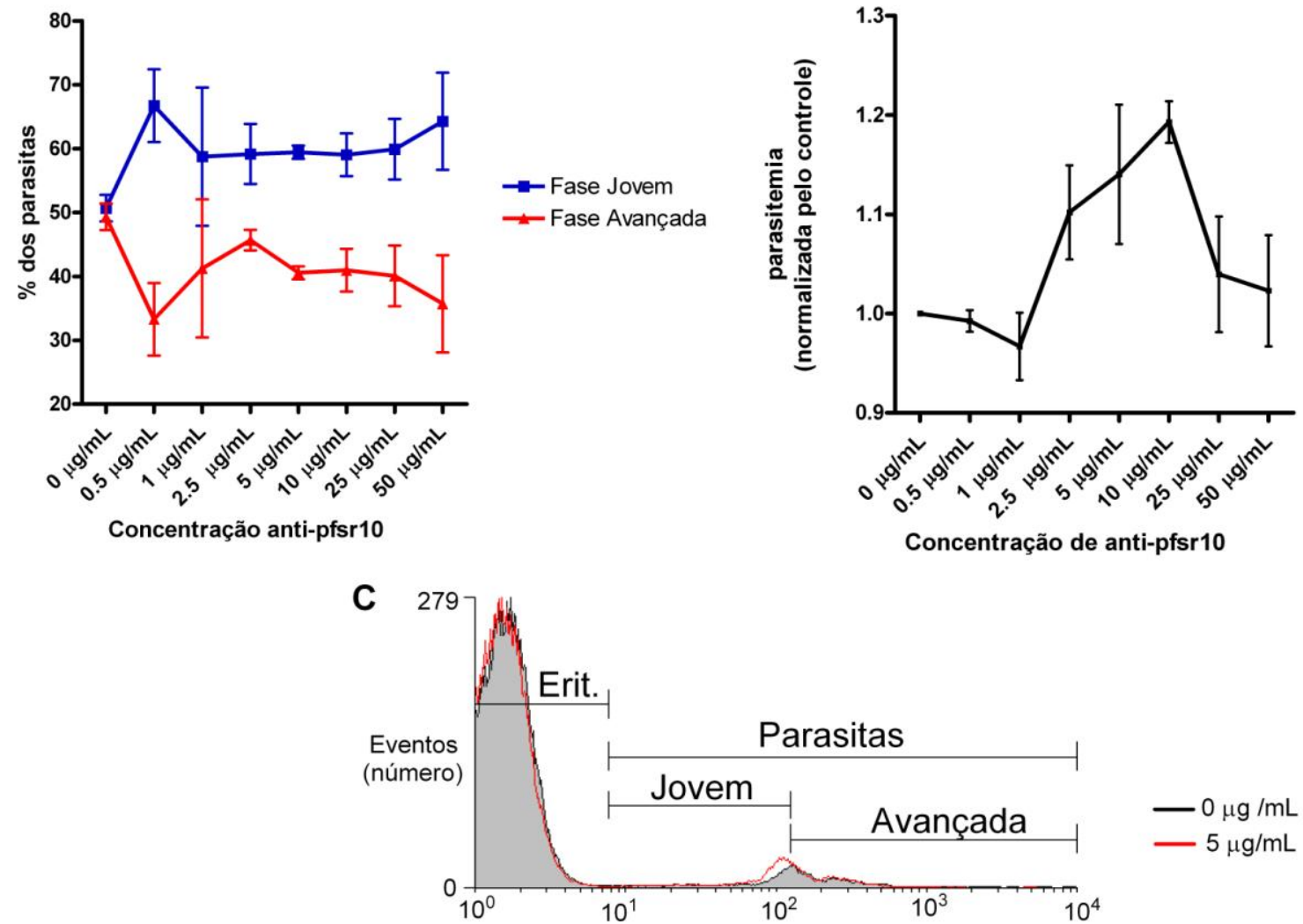

Esquizontes tardios de P. falciparum foram incubados com anticorpos em meio de cultura sem soro, durante $6 \mathrm{~h}$. $\mathrm{O}$ soro foi acrescentado e os parasitas foram cultivados durante $18 \mathrm{~h}$ antes da contagem de parasitemia utilizando citômetro de fluxo. A: proporção de fases intraeritrocíticas jovens e avançadas. B: Parasitemia, C: Histogramas representativos sobrepostos sem anticorpo e com $5 \mu \mathrm{g} / \mathrm{mL}$ de antipfsr10. Erit.: eritrócitos. Os resultados são de três experimentos independentes. Dados estão indicados como média terro padrão. Dados foram estatisticamente analisados por One-Way ANOVA e pós-teste de Newman-Keuls.

\subsubsection{Em sistema heterólogo, pfsr10 é identificada como proteína de aproximadamente 80}

\section{kDa e colocaliza parcialmente com a membrana plasmática}

A fim de executar ensaios funcionais com pfsr10, transfectamos o candidato a receptor em sistema heterólogo. Células HEK293T-PFSR10 foram incubadas com anticorpo anti-flag e marcador de membrana plasmática (aglutinina). A proteína pfsr10 foi detectada em maior ou menor grau, através de imunofluorescência, em parte da população de células HEK293TPFSR10 (Figura 13) enquanto células HEK293T-vazio não tiveram fluorescência evidente nas mesmas condições experimentais (resultados não mostrados). Após tomada de imagens por microscopia confocal, foi verificado que pfsr10 possui colocalização com a membrana plasmática de células HEK293T (Figura 14). Foi observada variação entre as células no que diz respeito à proporção de pfsr10 que colocaliza com a membrana plasmática (Figura 14). 
Figura 13 - Proporção de células HEK293T com expressão de pfsr10 identificada.

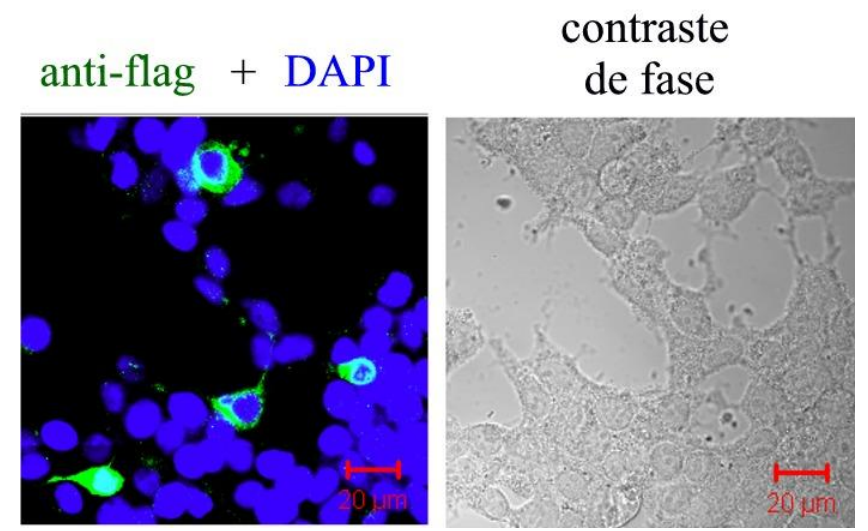

Células foram fixadas, bloqueadas e incubadas com anti-flag (1:500) e anticorpo anti-IgG de camundongo ligado a fluoróforo (em verde, na figura). O DNA foi marcado com DAPI (em azul).

A fim de verificar se pfsr10 é expresso em seu tamanho predito em células HEK293T, extratos de células HEK293T-PFSR10 foram submetidos a imunoprecipitação utilizando resina ligada ao anticorpo anti-Flag. Submetemos o imunoprecipitado a western blot. Para detectar pfsr10, utilizamos tanto anticorpo anti-pfsr10, direcionado contra uma porção Nterminal da proteína quanto anticorpo anti-flag, direcionado contra uma porção C-terminal da proteína (Figura 15 A-C). Em ambos os casos verificamos a presença de uma banda de aproximadamente $80 \mathrm{kDa}$, condizente com o peso molecular predito da proteína. 
Figura 14 - Localização subcelular de pfsr10 em células HEK293T.

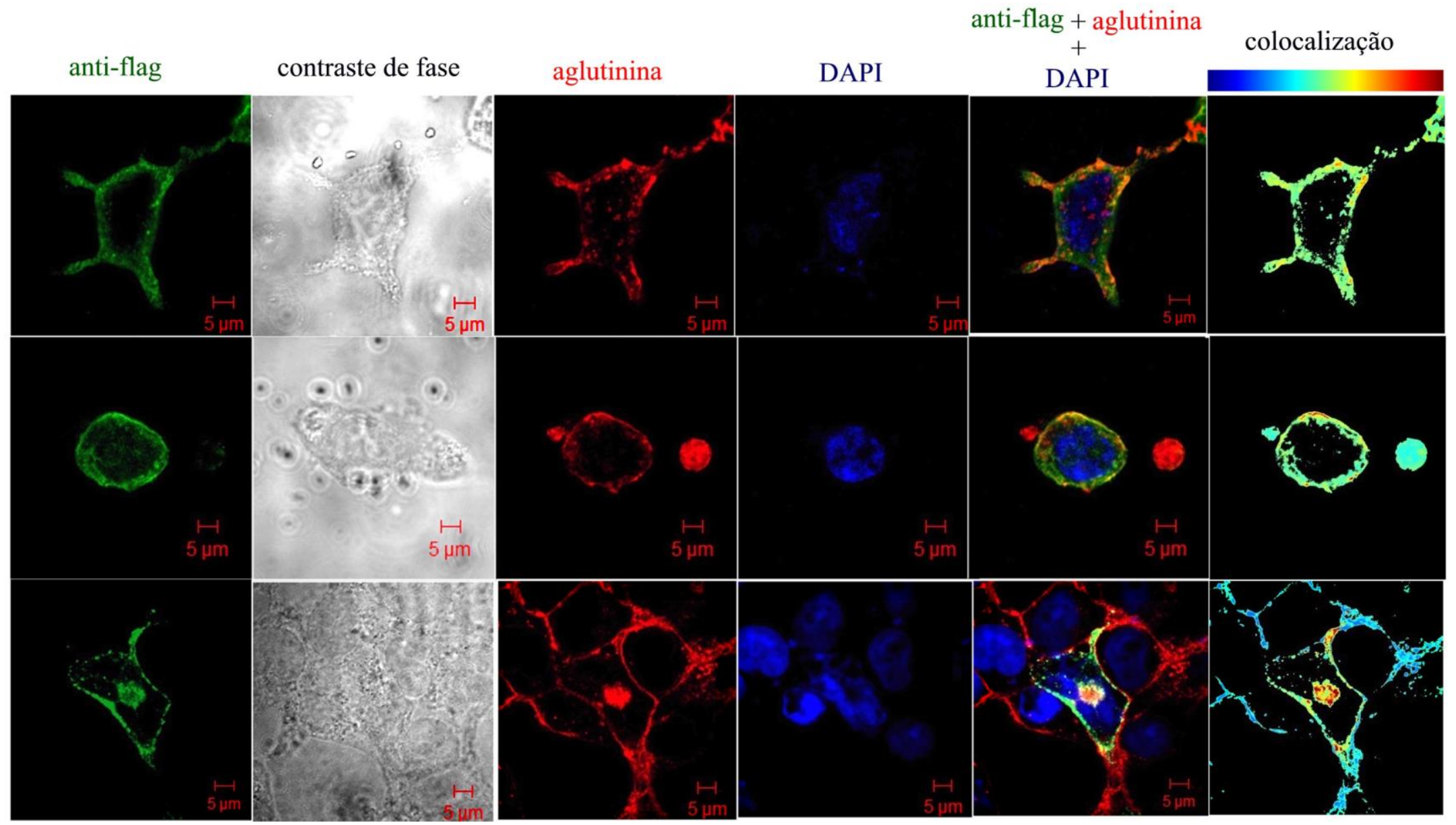

48 h após a transfecção, células HEK293T-PFSR10 foram incubadas com o marcador de membrana aglutinina ligado a Alexa 594 (10 $\mu \mathrm{g} / \mathrm{mL})$. As células foram fixadas, bloqueadas e incubadas com anti-Flag obtido em camundongo (1:500), anticorpo que reconhece um epítopo adicionado a C-terminal de pfsr10. Células foram incubadas com anticorpo anti-IgG de camundongo ligado a Alexa 488 (1:300). O DNA das células foi marcado com DAPI. A colocalização entre o epítopo flag e aglutinina foi obtida através do programa ImageJ, utilizando o plugin colocalization Colormap. Cores próximas ao vermelho indicam maior colocalização. As três células na figura apresentam algum grau de colocalização de pfsr10 com aglutinina (membrana plasmática). 
Figura 15 - Detecção de pfsr10 em células HEK293T através de imunoprecipitação seguida de western blot.

A

$$
\text { anti-pfsr10 }
$$

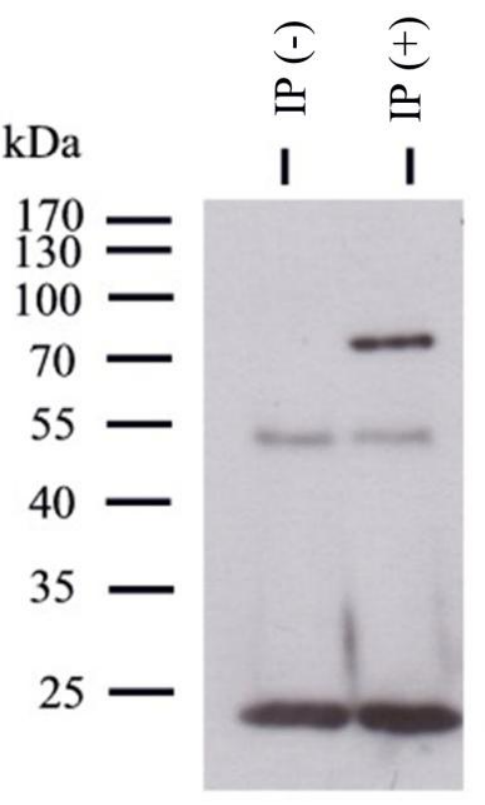

$\mathrm{B}$

$$
\text { anti-flag }
$$

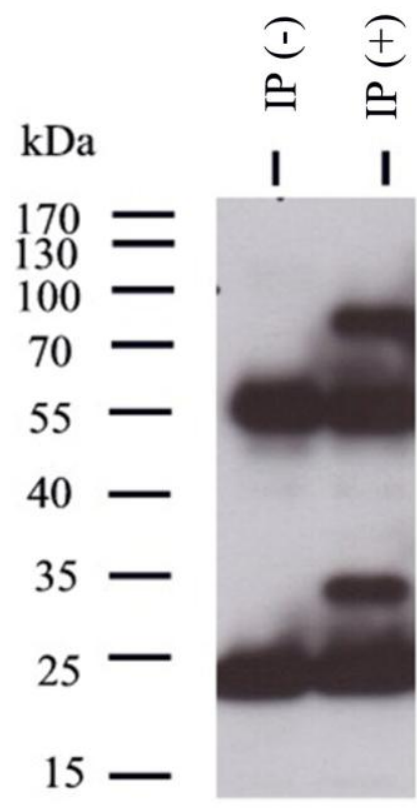

C

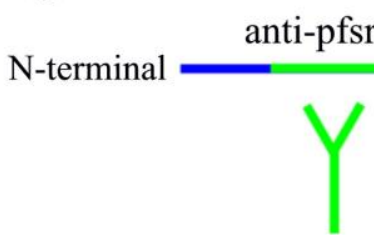

pfsr10 anti-flag C-terminal

Extratos celulares de células HEK293T-PFSR10 foram imunoprecipitados com anticorpo anti-Flag. Os imunoprecipitados foram submetidos a SDS-PAGE e transferidos para membrana de PVDF. Após bloqueio da membrana, esta foi submetida a incubação com anticorpo anti-pfsr10 (A) ou anticorpo anti-flag (B).e anticorpo secundário anti-IgG de coelho HRP. IP (-): imunoprecipitação executada apenas com resina. IP (+): imunoprecipitação executada com resina e anti-Flag. C- Esquema de ligação dos anticorpos utilizados na imunoprecipitação e western blot à proteína pfsr10 com relação às porções C- e N-terminal da proteína.

\subsubsection{Screening de agonistas para pfsr10: alguns nucleotídeos promovem maior aumento de $\left[\mathrm{Ca}^{2+}\right]_{\text {cit }}$ em células HEK293T-PFSR10+G ${ }_{a 15}$}

A fim de efetuar o screening de agonistas para o receptor serpentino putativo pfsr10 utilizamos compostos conhecidos por promoverem algum tipo de resposta fisiológica no parasita (melatonina, $\mathrm{N}$-acetilserotonina, serotonina, $\mathrm{KCl}$, ácido xanturênico, nucleotídeos, AMP cíclico) e outros compostos de que dispúnhamos em nosso laboratório (Tabela 1). Para os ensaios de dinâmica de cálcio em sistema heterólogo, transfectamos PFSR10 na linhagem celular HEK293T ou cotransfectamos PFSR10 com a proteína $G_{\alpha 15}$, que acopla 
promiscuamente diversos receptores serpentinos, ligando os mesmos à fosfolipase C (Offermanns e Simon, 1995). Marcamos as células com indicador fluorescente de $\left[\mathrm{Ca}^{2+}\right]_{\mathrm{cit}}$, Fluo-4 AM. Nos ensaios, adicionamos cálcio ao meio extracelular quando indicado ou quelamos o cálcio do meio extracelular com EGTA (Tabela 1). Não observamos aumento estatístico das respostas de cálcio induzidas pelos compostos acima nas células HEK293TPFSR10 ou HEK293T-PFSR10+G $\alpha_{\alpha 15}$ em relação aos respectivos controles negativos (Tabela 1).

Tabela 1 - Screening de agonistas para pfsr10 em células HEK293T.

\begin{tabular}{|c|c|c|c|}
\hline Composto & Transfecção & $\begin{array}{c}\text { Meio } \\
\text { extracelular }\end{array}$ & $\begin{array}{c}\text { \% da resposta de } \\
{\left[\mathrm{Ca}^{2+}\right]_{\text {cit }} \text { em relação }} \\
\text { à resposta do } \\
\text { controle; (número de } \\
\text { gráficos/número de } \\
\text { experimentos) }\end{array}$ \\
\hline $\begin{array}{c}\text { Melatonina } \\
100 \mathrm{nM}\end{array}$ & PFSR10 & $\mathrm{CaCl}_{2} 2 \mathrm{mM}$ & $\begin{array}{l}94 \pm 8 \\
(20 / 3)\end{array}$ \\
\hline $\begin{array}{c}\mathrm{N} \text {-acetilserotonina } \\
100 \mathrm{nM}\end{array}$ & PFSR10 & $\mathrm{CaCl}_{2} 2 \mathrm{mM}$ & $\begin{array}{l}88 \pm 5 \\
(30 / 5)\end{array}$ \\
\hline $\begin{array}{l}\text { Serotonina } \\
100 \mathrm{nM}\end{array}$ & PFSR10 & $\mathrm{CaCl}_{2} 2 \mathrm{mM}$ & $\begin{array}{l}122 \pm 8 \\
(20 / 5)\end{array}$ \\
\hline $\begin{array}{l}\text { Triptamina } \\
100 \mathrm{nM}\end{array}$ & PFSR10 & $\mathrm{CaCl}_{2} 2 \mathrm{mM}$ & $\begin{array}{c}93 \pm 12 \\
(3 / 1)\end{array}$ \\
\hline $\begin{array}{c}\text { Acetilcolina } \\
10 \mu \mathrm{M}\end{array}$ & PFSR10 & $\mathrm{CaCl}_{2} 2 \mathrm{mM}$ & $\begin{array}{c}93 \pm 16 \\
(4 / 4)\end{array}$ \\
\hline $\begin{array}{c}\text { Acetilcolina } \\
10 \mu \mathrm{M}\end{array}$ & PFSR $10+G \alpha_{15}$ & $\mathrm{CaCl}_{2} 2 \mathrm{mM}$ & $\begin{array}{l}113 \pm 6 \\
(24 / 3)\end{array}$ \\
\hline $\begin{array}{c}\text { Acetilcolina } \\
10 \mu \mathrm{M}\end{array}$ & PFSR $10+G \alpha_{15}$ & EGTA 2 mM & $\begin{array}{l}94 \pm 6 \\
(22 / 3)\end{array}$ \\
\hline $\begin{array}{c}\text { Ácido Xanturênico } \\
100 \mathrm{nM}\end{array}$ & PFSR10 & $\mathrm{CaCl}_{2} 2 \mathrm{mM}$ & $\begin{array}{c}131 \pm 23 \\
(7 / 2)\end{array}$ \\
\hline $\begin{array}{c}\mathrm{KCl} \\
142 \mathrm{mM}\end{array}$ & PFSR10 & $\mathrm{CaCl}_{2} 2 \mathrm{mM}$ & $\begin{array}{l}95 \pm 5 \\
(15 / 3)\end{array}$ \\
\hline $\begin{array}{c}\mathrm{KCl} \\
142 \mathrm{mM}\end{array}$ & PFSR $10+G \alpha_{15}$ & $\mathrm{CaCl}_{2} 2 \mathrm{mM}$ & $\begin{array}{l}106 \pm 5 \\
(21 / 3)\end{array}$ \\
\hline $\begin{array}{c}\mathrm{KCl} \\
142 \mathrm{mM}\end{array}$ & PFSR $10+G \alpha_{15}$ & EGTA 2 mM & $\begin{array}{c}114 \pm 6 \\
(4 / 1)\end{array}$ \\
\hline $\begin{array}{l}\mathrm{AMPc} \\
1 \mu \mathrm{M}\end{array}$ & PFSR10 & $\mathrm{CaCl}_{2} 2 \mathrm{mM}$ & $\begin{array}{c}46 \pm 7^{*} \\
(3 / 1)\end{array}$ \\
\hline $\begin{array}{l}\text { Somatostatina } \\
100 \mathrm{nM}\end{array}$ & PFSR10 & $\mathrm{CaCl}_{2} 2 \mathrm{mM}$ & $\begin{array}{c}87 \pm 3 \\
(3 / 1)\end{array}$ \\
\hline $\begin{array}{l}\text { Angiotensina } \\
100 \mathrm{nM}\end{array}$ & PFSR10 & $\mathrm{CaCl}_{2} 2 \mathrm{mM}$ & $\begin{array}{l}114 \pm 11 \\
(3 / 1)\end{array}$ \\
\hline $\begin{array}{l}\mathrm{CaCl}_{2} \\
2 \mathrm{mM}\end{array}$ & PFSR10 & $\mathrm{CaCl}_{2} 0 \mathrm{mM}$ & $\begin{array}{c}104 \pm 4 \\
(6 / 1)\end{array}$ \\
\hline
\end{tabular}

O aumento de fluorescência do marcador de cálcio Fluo-4 AM após estímulo com os compostos foi calculado através da diferença entre fluorescência máxima e fluorescência mínima após a normalização dos gráficos pela fluorescência basal. O aumento de cálcio nas transfecções com PFSR10 ou PFSR10 e $\mathrm{G} \alpha_{15}$ (proteína G promíscua) foram comparados com os aumentos nos respectivos controles, transfectados com plasmídeo vazio ou plasmídeo vazio e $\mathrm{G \alpha}_{15}$. O meio 
extracelular foi suplementado com $\mathrm{CaCl}_{2}$ quando indicado ou teve o cálcio extracelular quelado com EGTA, exceto no estímulo com $\mathrm{CaCl}_{2}$ executado em meio extracelular sem adição de cálcio. Os dados foram submetidos a teste estatístico One-Way ANOVA com pós-teste de Dunnett. * indica diferença estatística em relação ao controle ( $\mathrm{p}<0.05)$. Dados estão na forma média \pm erro padrão.

Decidimos também utilizar como agonistas os nucleotídeos ATP, ADP, GTP, UTP e adenosina, alguns dos quais induzem aumento de $\left[\mathrm{Ca}^{2+}\right]_{\mathrm{cit}}$ em parasitas do gênero Plasmodium (da Cruz et al., 2012; Levano-Garcia et al., 2010; Ono et al., 2008). Em células HEK293TPFSR10 notamos aumento similar de cálcio citosólico após estímulo com ATP em relação a células transfectadas apenas com plasmídeo vazio (Figura 16 A). Quando células HEK293TPFSR10+G $\mathrm{G}_{\alpha 15}$ foram estimuladas com ATP, porém, notamos uma resposta estatisticamente maior $(1,89 \pm 0,08$, média \pm erro padrão) dessas células em relação a células HEK293Tvazio+ $\mathrm{G}_{\alpha 15}$ (Figura 16 B). Interessantemente, quando o experimento é executado na ausência de cálcio extracelular (presença do quelante de cálcio EGTA) verificamos que a resposta diferencial é abolida (Figura 16 C). O mesmo padrão de resposta foi obtido com ADP, GTP e UTP, sendo que a análise estatística apontou para aumento significativo da resposta de $\left[\mathrm{Ca}^{2+}\right]_{\mathrm{cit}}$ versus o aumento de $\left[\mathrm{Ca}^{2+}\right]_{\mathrm{cit}}$ em células HEK293T-vazio+ $\mathrm{G}_{\alpha 15}$, na presença de cálcio extracelular (aumentos de, respectivamente, $1,7 \pm 0.1 ; 1.5 \pm 0.1$ e $1.40 \pm 0.03$ Figura 16 D). Porém, da mesma maneira que ATP, os nucleotídeos ADP, GTP e UTP, não promoveram aumento diferencial de $\left[\mathrm{Ca}^{2+}\right]_{\text {cit }}$ em células HEK293T-PFSR10 $+\mathrm{G}_{\alpha 15}$ em relação a células HEK293T-vazio+G $\mathrm{G}_{\alpha 15}$ quando o cálcio do meio extracelular foi quelado com EGTA (Figura 16 D). Células HEK293T-PFSR10 estimuladas com ADP, GTP ou UTP não apresentaram aumentos de $\left[\mathrm{Ca}^{2+}\right]_{\text {cit }}$ estatisticamente diferentes de células HEK293T-vazio (Figura 16 D), sugerindo que $\mathrm{G}_{\alpha 15}$ é importante para a resposta de $\left[\mathrm{Ca}^{2+}\right]_{\text {cit }}$ dependente de PFSR10. 
Figura 16 - Dinâmica de cálcio em células HEK293T transfectadas com PFSR10 e estimuladas com nucleotídeos (50 $\mu \mathrm{M})$.
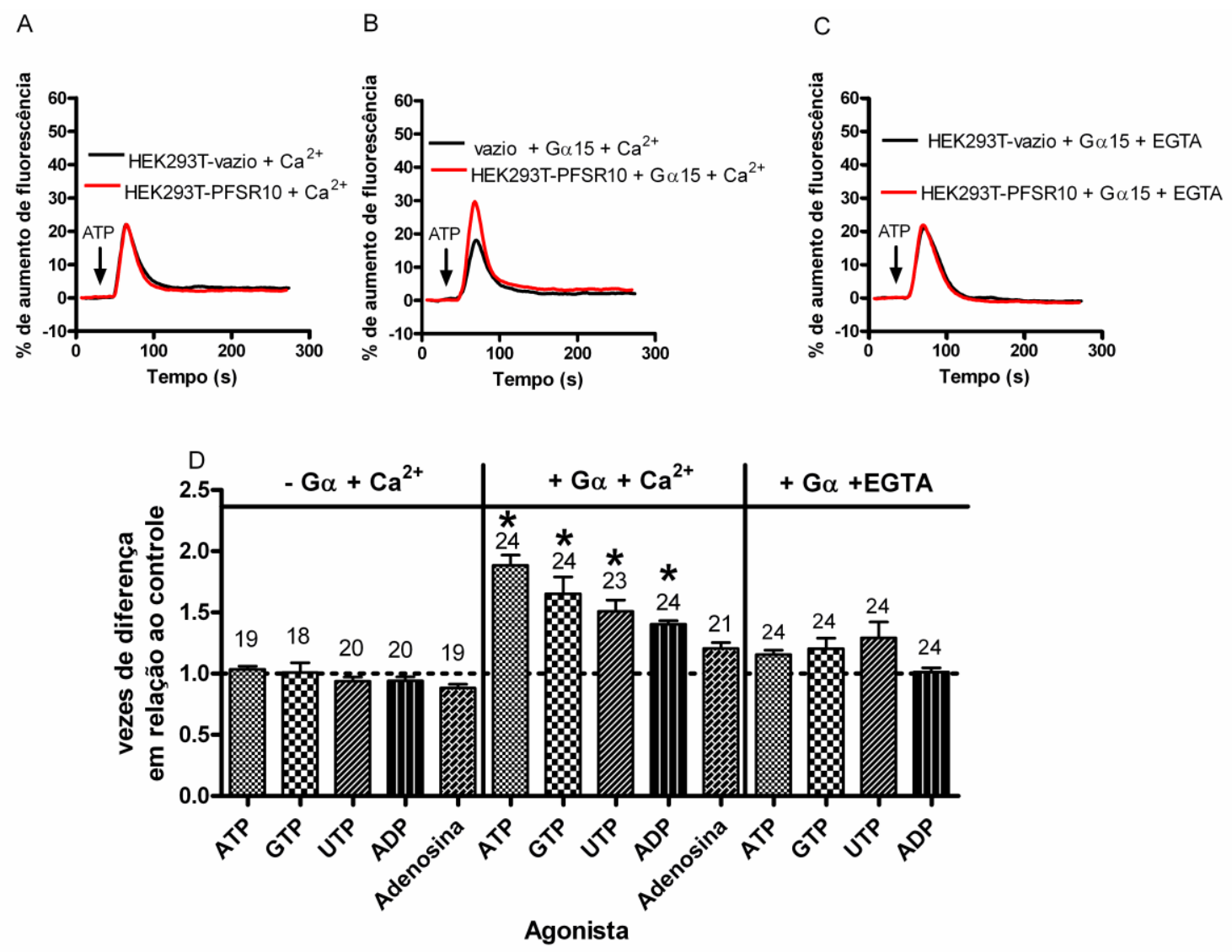

A,B,C: Gráficos representativos de dinâmica de cálcio obtidos com ATP (gráficos na forma de \% de aumento de fluorescência em relação à linha basal). A: Transfecção de PFSR10 ou plasmídeo vazio, experimento na presença de $2 \mathrm{mM}$ de cálcio extracelular. B: cotransfecção de PFSR10 e G $\alpha_{15}$ ou cotransfecção de plasmídeo vazio e $\mathrm{G \alpha}_{15}$, experimento na presença de $2 \mathrm{mM}$ de cálcio extracelular. C: cotransfecção de PFSR 10 e $\mathrm{G} \alpha_{15}$ ou cotransfecção de plasmídeo vazio e $\mathrm{G} \alpha_{15}$, experimento na presença de $2 \mathrm{mM}$ de quelante extracelular de cálcio (EGTA). D: análise estatística do aumento de cálcio nos diferentes tratamentos e transfecções. Aumentos de cálcio citosólico em células transfectadas com PFSR10 foram normalizados pelos aumentos citossólicos de cálcio dos respectivos controles (linha tracejada). $-\mathrm{G} \alpha+\mathrm{Ca}^{2+}$ : células transfectadas apenas com PFSR10, ensaio na presença de cálcio extracelular. $+\mathrm{G} \alpha+\mathrm{Ca}^{2+}$ : células cotransfectadas

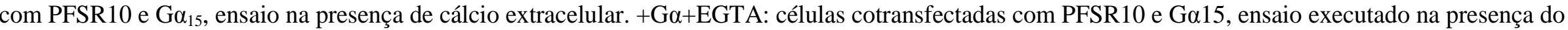
quelante extracelular de cálcio EGTA. * indica diferença significativa em relação ao respectivo controle (One-Way ANOVA com teste de Newman-Keuls). Os resultados são de três experimentos independentes. Os números acima das barras indicam o número de gráficos de fluorescência analisados. Dados estão plotados na forma de média e erro padrão. 
Comparando as respostas de $\left[\mathrm{Ca}^{2+}\right]_{\mathrm{cit}}$ estatisticamente distintas, em relação aos controles, promovidas por ATP, GTP, UTP e ADP em células HEK293T-PFSR10+G ${ }_{\alpha 15}$ em meio extracelular contendo cálcio, verificamos uma clara diferença de potência dos agonistas: ATP > GTP > UTP > ADP (Figura 16 D).

Interessantemente, para adenosina, não observamos resposta diferencial entre transfecções com PFSR10 e controles em nenhum dos casos (Figura 16 D). Para verificar se as diferenças notadas não seriam devidas a um crescimento diferencial das células (i.e., que houvesse um maior número de células HEK293T-PFSR10+G $\mathrm{G}_{\alpha 15}$ que células HEK293Tvazio $+\mathrm{G}_{\alpha 15}$ em nossos experimentos de dinâmica de cálcio), efetuamos contagens das células transfectadas, verificando que o número de células entre as transfecções não foi estatisticamente diferente ao longo de 24, 48 e 120 h (Figura 17).

Figura 17 - Crescimento de células HEK293T-PFSR10+G $\alpha_{15}$ ou HEK293T-vazio+G $\alpha_{15}$.

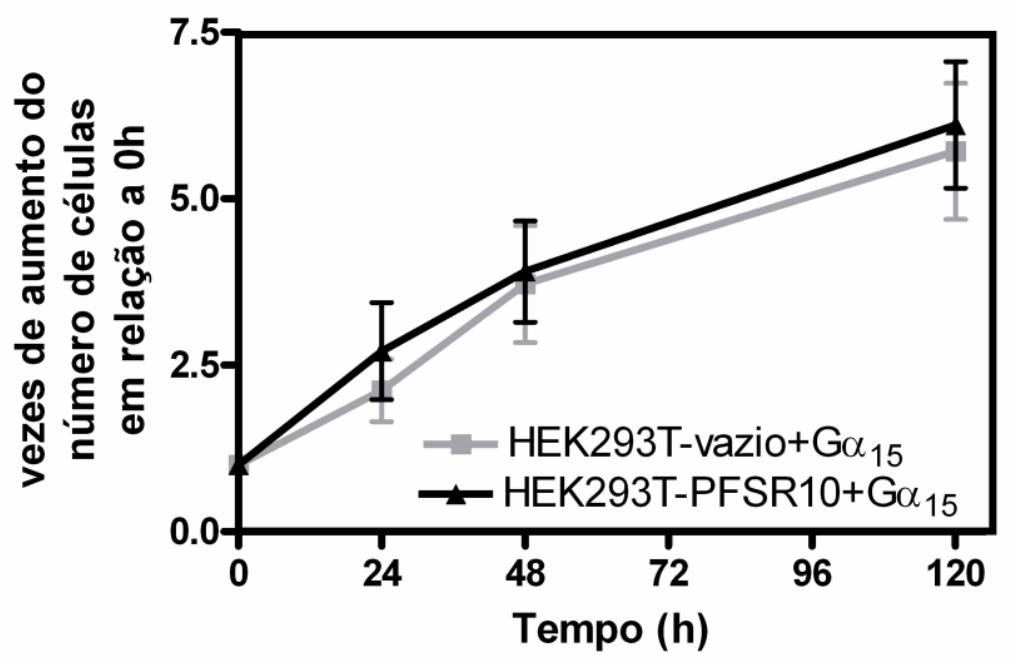

Dados normalizados pelo número de células inicial (transfectadas em $0 \mathrm{~h}$ ). $\mathrm{O}$ número acima das barras indica o número de replicas. Dados estão plotados na forma de média e erro padrão. Resultados são de três experimentos independentes. Dados foram analisados estatisticamente por teste $t$ não pareado, não sendo observadas diferenças estatísticas.

Obtivemos, assim, resultados de dinâmica de cálcio em células HEK293T que sugerem que pfsr10 participa na via de transdução de sinal induzida por ATP. Porém a alta expressão de receptores purinérgicos endógenos em HEK293T celular dificulta uma análise conclusiva do papel de pfsr10. Desse modo, decidimos utilizar a linhagem celular 1321N1, comumente utilizada para a caracterização funcional de receptores purinérgicos. Utilizamos, também, outra técnica de medida de cálcio através da utilização de aequorina (Brini et al., 
1995). Essa técnica é indicada para medir dinâmica de cálcio apenas em células transfectadas, visto que a aequorina é cotransfectada com PFSR10.

Figura 18 - Ensaios de cálcio utilizando aequorina em células 1321N1 transfectadas com PFSR10 e expressão e localização do receptor em células 1321N1. A
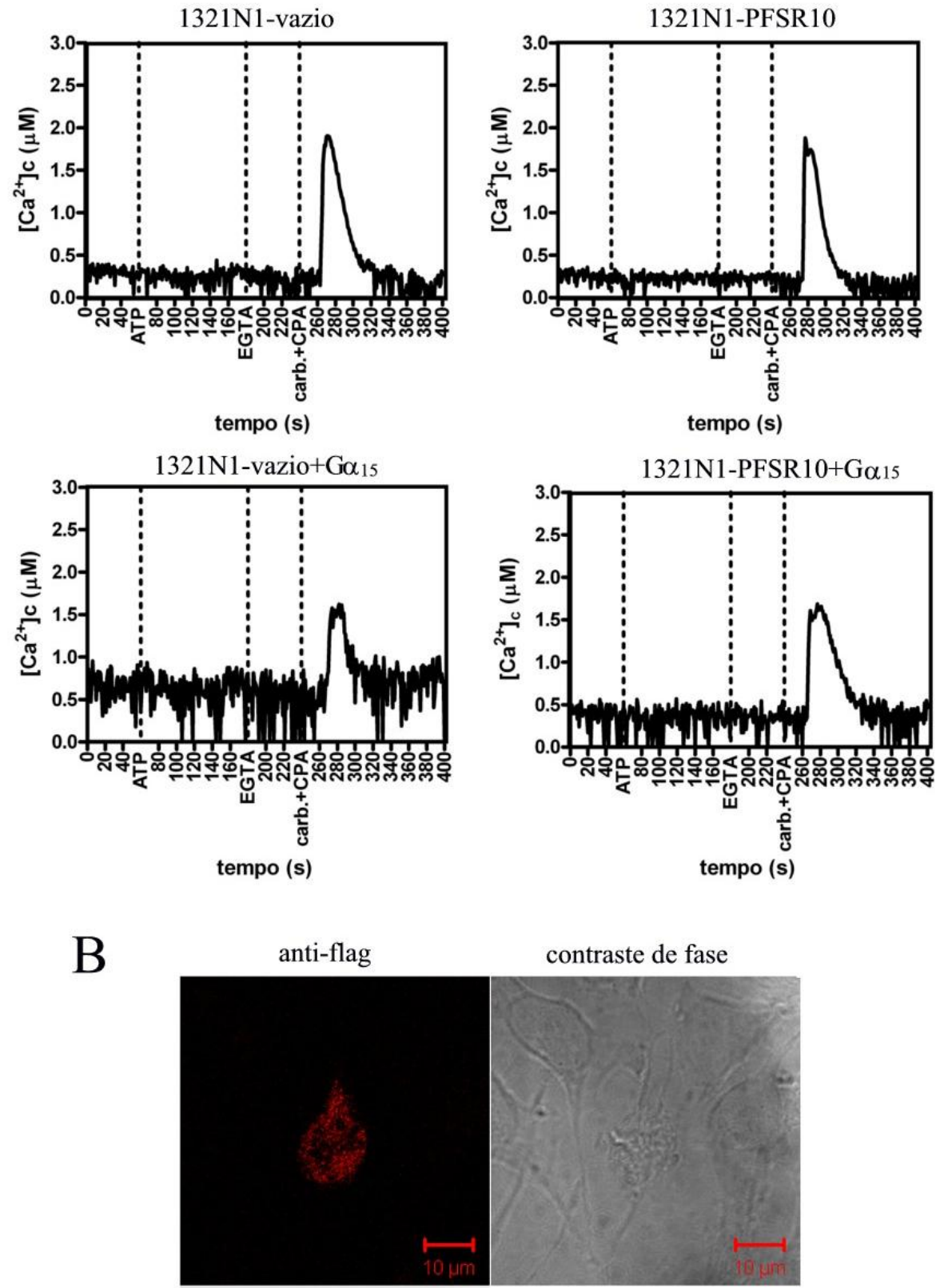

A: Ensaios de cálcio em células transfectadas com PFSR10, plasmídeo vazio e $G \alpha_{15}$ nas combinações indicadas. As linhas transversais tracejadas indicam perfusão do(s) composto(s) indicado(s). ATP foi utilizado na concentração de $50 \mu \mathrm{M}$. Carbacol (carb.) e ácido ciclopiazônico (CPA) foram utilizados na concentração de $500 \mu \mathrm{M}$ e $20 \mu \mathrm{M}$, respectivamente. EGTA foi utilizado na concentração de 600 $\mu \mathrm{M}$. B: Imunofluorescência de PFSR10 transfectado em células 1321N1. O anticorpo anti-flag foi utilizado para detectar localização de pfsr10. 
A cotransfecção de PFSR10, Ga15 e aequorina nessas células não induziu aumentos intracelulares de cálcio em resposta a ATP (Figura 18 A). Porém, em ensaios de imunofluorescência em células $1321 \mathrm{~N} 1$ a proteína pfsr10 parece estar localizada intracelularmente, com baixa localização de membrana (Figura 18 B) e também foi observado que poucas células parecem expressar pfsr10. Além disso, é importante notar que a aequorina foi cotransfectada com PFSR10 e $\mathrm{G} \alpha_{15}$ inclusive na metade da concentração dos primeiros dois plasmídeos e a amplitude da resposta obtida após estímulo com carbacol e ácido ciclopiazônico (controle positivo) é alta (Figura 18 A) indicando boa eficiência de transfecção. Assim, a baixa expressão de pfsr10 não se deve à baixa eficiência de transfecção.

\subsubsection{Transfecção de PFSR10 e Ga promove aumento de fosforilação em células HEK293T}

Testamos a capacidade de PFSR10 alterar componentes downstream de sinalização verificando o padrão de fosforilação de proteínas de células HEK293T-PFSR10+G $\alpha_{15}$ quando estimuladas com ATP. Utilizamos para tanto células estimuladas com diferentes concentrações do nucleotídeo e incubamos membranas de western blot com anticorpos antifosfoserina (Figura 19 A) e anti-fosfotirosina (Figura 19 B), normalizando a intensidade das bandas escolhidas pela intensidade das bandas de actina, utilizadas como controle da quantidade de proteína aplicada no gel.

Tratamentos com ATP promoveram um aumento na fosforilação de proteínas em relação a células não tratadas com ATP, na maioria dos casos (Figura 20 A, Figura 20 B). Em células HEK293T-PFSR10+G $\alpha_{15}$, para as concentrações de ATP de $100 \mathrm{nM}, 1 \mu \mathrm{M}$ e 50 $\mu \mathrm{M}$, houve tendência geral de menor aumento de fosforilação de proteínas em resíduos de serina (Figura 20 A) e em resíduos de tirosina (Figura 20 B) em relação a células HEK293Tvazio+G $\alpha_{15}$ estimuladas com as mesmas concentrações de ATP. Porém, para uma banda fosforilada em resíduos de tirosina, com massa molecular entre $130 \mathrm{kDa}$ e $170 \mathrm{kDa}$, foi observada significância estatística entre o aumento de fosforilação em células HEK293Tvazio+G $\alpha_{15}$ e a fosforilação de células HEK293T-PFSR10+G $\alpha_{15}$ (Figura 20 B). 
Figura 19 - Fosforilação de proteínas de células HEK293T-PFSR10+Ga $\alpha_{15}$ ou HEK293Tvazio+ $+\mathrm{G}_{15}$.
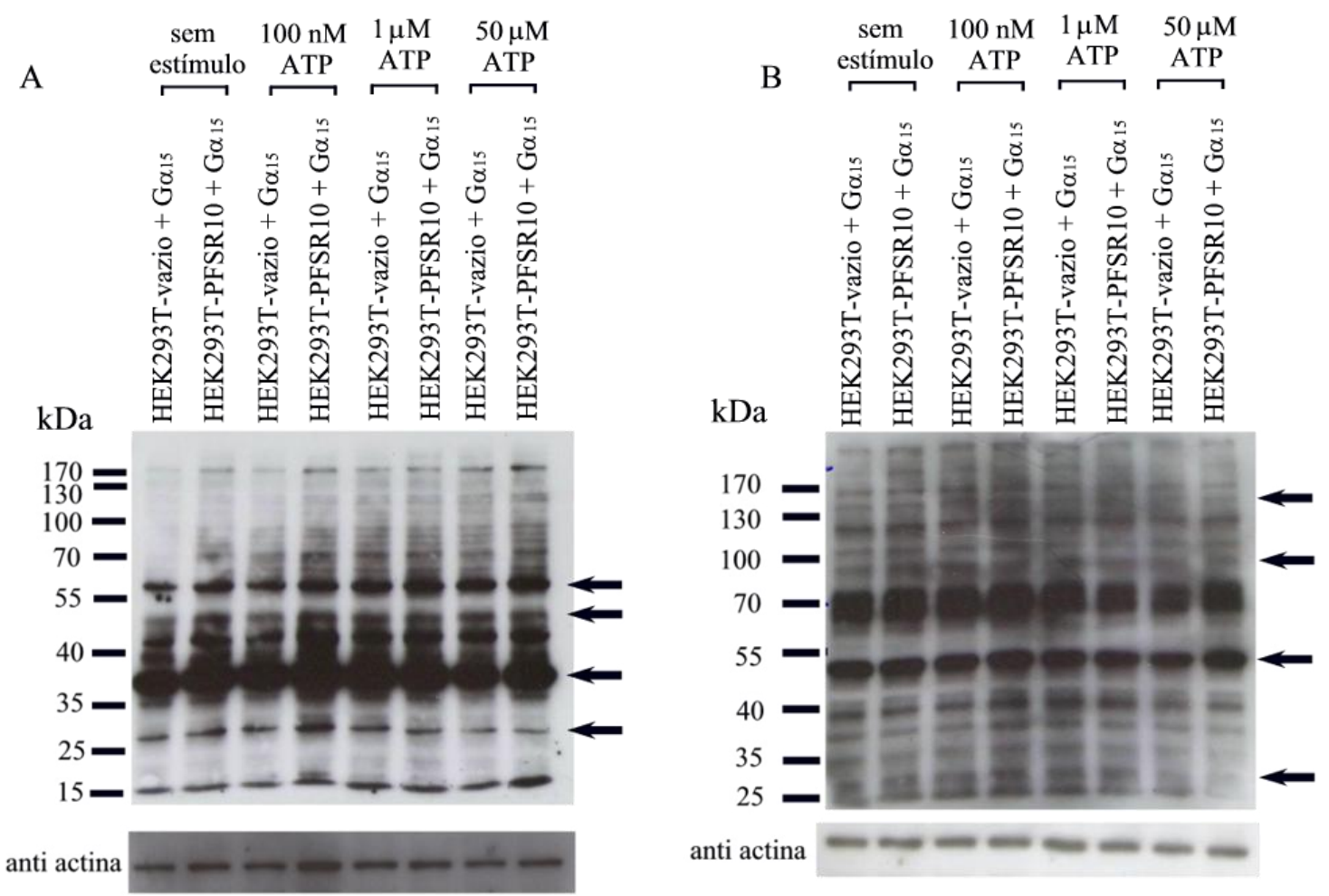

A: Proteínas fosforiladas detectadas com anti-fosfoserina. B: Proteínas fosforiladas detectadas com anti-fosfotirosina. Algumas bandas presentes nos três experimentos executados (indicadas por flechas) foram selecionadas para quantificação relativa da fosforilação. As concentrações de ATP utilizadas para o estímulo, que teve duração de 10 minutos, estão indicadas. O controle do carregamento do gel foi executado detectando-se actina.

Como a fosforilação de proteínas de células tratadas com ATP havia sido normalizada pelos respectivos controles sem estímulo de ATP (HEK293T-vazio+Ga $\alpha_{15}$ ou HEK293TPFSR10+G $\alpha_{15}$ ), decidimos verificar se a fosforilação basal nas duas transfecções na ausência de estímulo era diferente. De fato, a fosforilação basal de células HEK293T-PFSR10+G $\alpha_{15}$ teve tendência de ser maior em todas as bandas analisadas, tanto no caso de uso do anticorpo anti-fosfoserina (Figura 21 A) quanto no caso de uso de anti-fosfotirosina (Figura 21 B). No caso da banda com massa molecular entre $130 \mathrm{kDa}$ e $170 \mathrm{kDa}$ a fosforilação foi significativamente diferente em relação a HEK293T-vazio+G $\alpha_{15}$. 
Figura 20 - Alteração de fosforilação de proteínas após estímulo com ATP em células HEK293T-PFSR 10+G $\alpha_{15}$ ou HEK293T-vazio $+\mathrm{G} \alpha_{15}$.

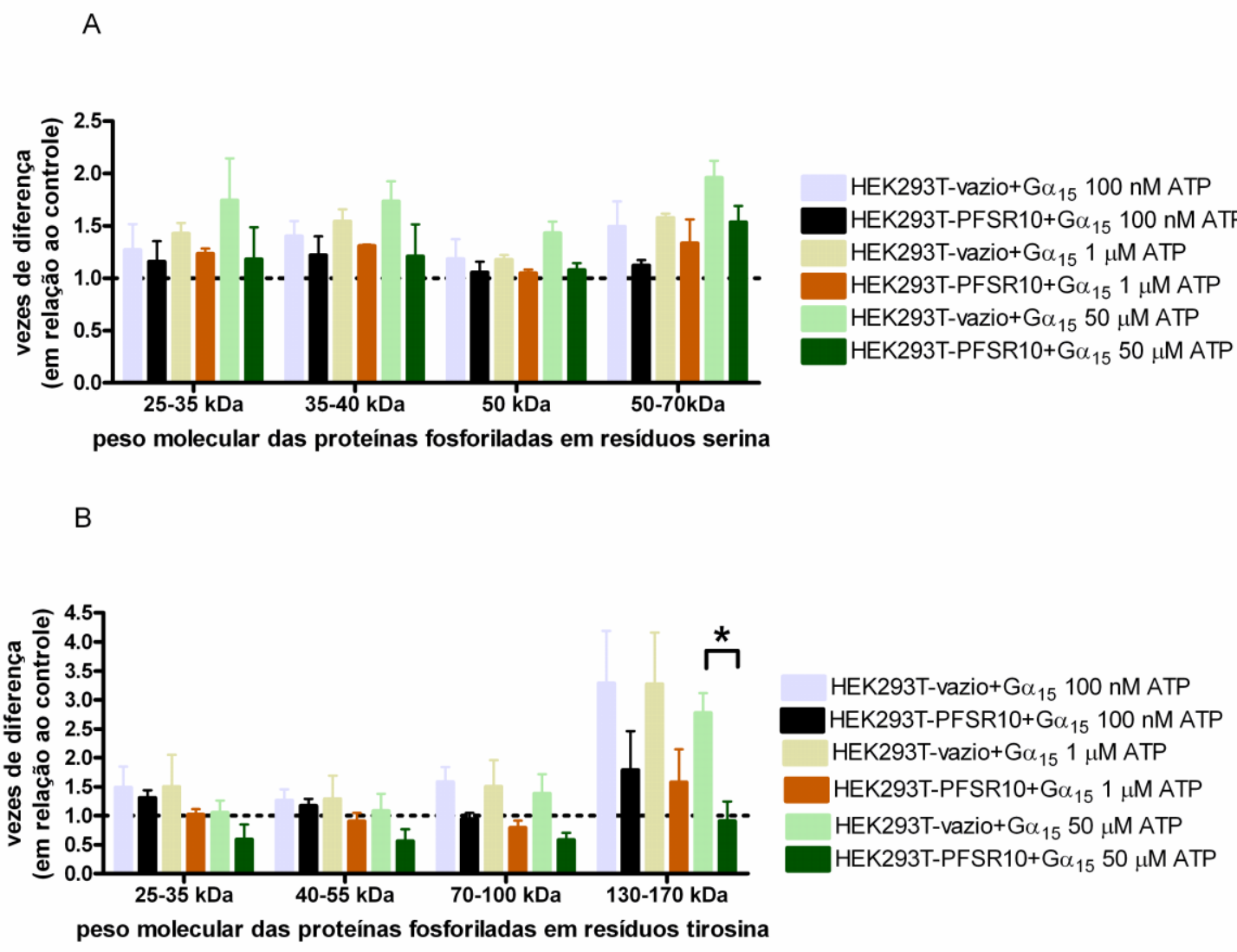

Bandas fosforiladas foram normalizadas pelo controle de carregamento do gel (actina) e em seguida, foram normalizadas pelo respectivo controle sem estímulo com ATP (cotransfecção com plasmídeo vazio e $\mathrm{G} \alpha_{15}$ ou cotransfecção com PFSR10 e $\mathrm{G} \alpha_{15}$ ). Os controles estão indicados através de traços no gráfico. * indica diferença significativa entre as alterações de fosforilação indicadas (teste $\mathrm{t}$ não pareado). Dados estão plotados na forma de média e erro padrão. Resultados são de três experimentos independentes. A: Fosforilação relativa de proteínas em resíduos de fosfoserina. B: Fosforilação relativa de proteínas em resíduos de fosfotirosina.

É conhecido que diversos receptores de sete domínios transmembrânicos ativam MAPK (revisado em Seger e Krebs, 1995). As proteínas MAPK são ativadas, via fosforilação, por proteínas MAPKK. Como observamos que a cotransfecção de PFSR10 e Ga $\alpha_{15}$ provocou um aumento da fosforilação em proteínas de células HEK293T, decidimos verificar se proteínas MAPK poderiam ser fosforiladas. Para tanto, utilizamos dois anticorpos, o primeiro que reconhece as MAPKs ERK1/2 tanto na forma fosforilada quanto na forma defosforilada (proteína total) e o segundo que reconhece as MAPKs ERK1/2 apenas forma fosforilada. ERK1 possui um tamanho aproximado de $44 \mathrm{kDa}$ e ERK2, $42 \mathrm{kDa}$. O anticorpo contra proteína total reconheceu ERK 1 e ERK 2, visualizadas como bandas duplas, em todas as transfecções e tratamentos com concentrações distintas de ATP (Figura 22). Porém, as 
formas fosforiladas de ERK 1/2 foram fracamente detectadas no western blot em todas as transfecções e tratamento com ATP (Figura 22), sugerindo a não participação destas quinases na resposta induzida por ATP em células HEK293T-PFSR10. Em geral, bandas intensas são detectadas quando há fosforilação de ERK 1/2.

Figura 22 - Fosforilação de proteínas de células HEK293T-PFSR10+G $\alpha_{15}$ em relação ao controle transfectado com plasmídeo vazio e $\mathrm{G}_{15}$.
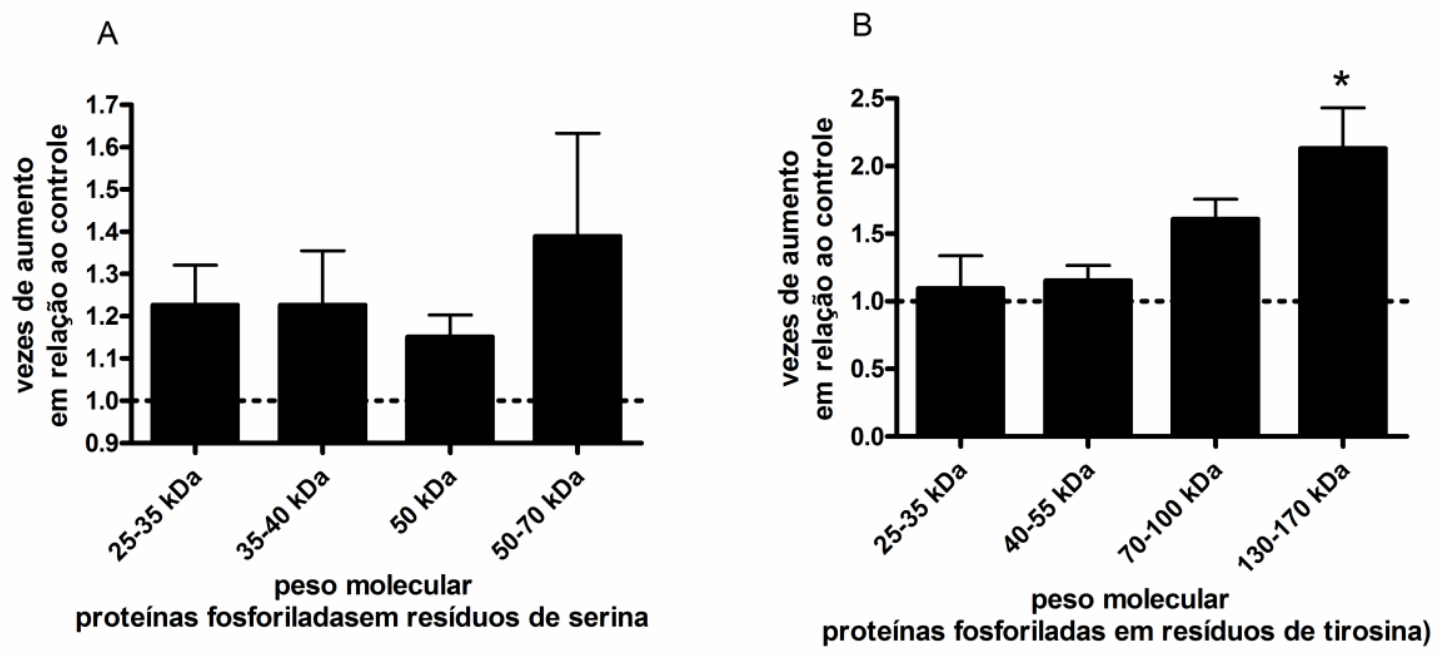

A: Fosforilação em resíduos de serina, B: Fosforilação em resíduos de tirosina. O controle está indicado através de um traço. * indica diferença estatística em relação ao controle (One Way ANOVA, teste de Newman Keuls). Dados estão plotados na forma de média e erro padrão. Resultados são de três experimentos independentes.

Figura 21 - Análise da fosforilação de ERK1/2 em células HEK293T-PFSR10 e Ga $\alpha_{15}$ ou HEK293T-vazio $+\mathrm{G} \alpha_{15}$. Os estímulos com diferentes concentrações de ATP tiveram duração de 10 minutos. Experimento representativo de três experimentos.

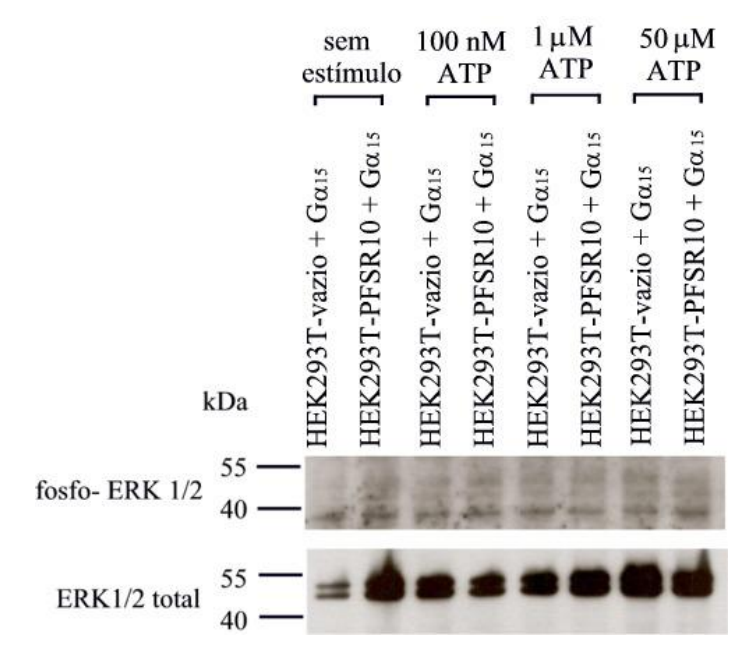


Figura 23 - Imunoprecipitação de proteínas em P. falciparum com anticorpo antipfsr10.

A

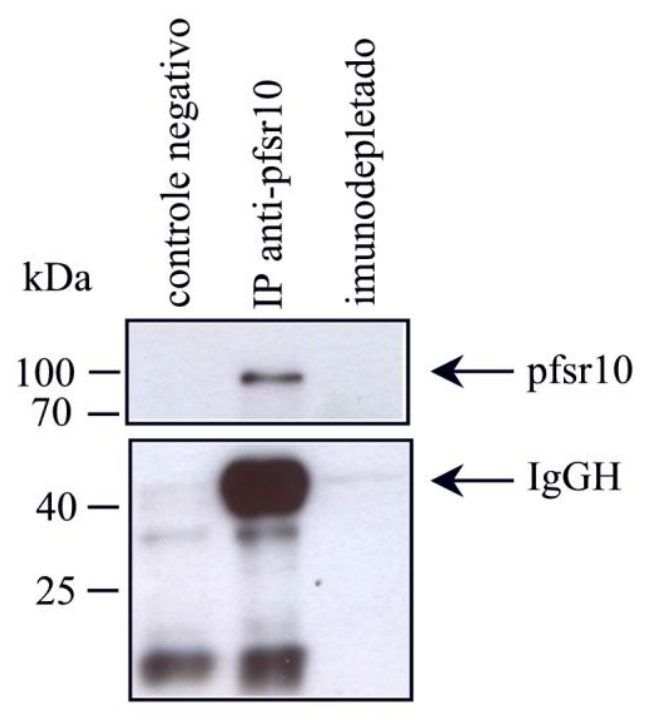

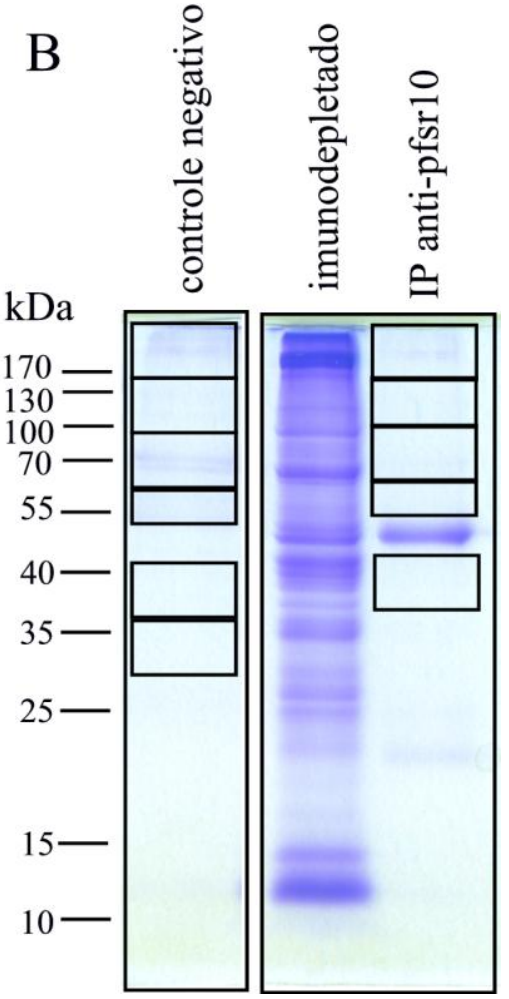

A: Western blot indicando controle negativo (incubação do extrato com resina), imunoprecipitação (IP) utilizando anticorpo anti-pfsr10 e extrato imunodepletado. IgGH: cadeia pesada do anticorpo utilizado na imunoprecipitação. B: SDS-PAGE indicando faixas do gel (entre retângulos) enviadas para identificação de proteínas por espectrometria de massa. Lanes: controle negativo (uso apenas de resina na imunoprecipitação, sem anticorpo), imunoprecipitação (IP) utilizando anticorpo anti-pfsr10 e o extrato proteico restante após a imunoprecipitação (imunodepletado).

\subsubsection{Proteínas candidatas a interagir com pfsr10 desempenham diversas funções celulares}

Com o intuito de identificar parceiros moleculares de pfsr10 em P. falciparum, executamos experimentos de imunoprecipitação utilizando anticorpo anti-pfsr10. Através de western blot, identificamos pfsr10 no imunoprecipitado, o que valida o protocolo utilizado (Figura 23 A).

Para identificar proteínas parceiras moleculares de pfsr10, corremos proteínas imunoprecipitadas em SDS-PAGE e dividimos o gel em diversos pedaços (Figura 23 B), que foram enviados para análise de espectrometria de massa. Com a finalidade de executar uma análise mais restringente, comparamos os resultados de imunoprecipitação com anticorpo anti-pfsr10 com um controle negativo, no qual o extrato proteico de $P$. falciparum foi incubado apenas com resina. 
Os peptídeos identificados na imunoprecipitação de proteínas de $P$. falciparum utilizando o anticorpo anti-pfsr10 corresponderam a 311 proteínas no genoma de $P$. falciparum, ao passo que no controle negativo os peptídeos identificados corresponderam 353 proteínas. Dentre as proteínas identificadas no imunoprecipitado com anticorpo anti-pfsr10, 79 não tiveram peptídeos identificados no controle negativo (Tabela 2). Foram observadas também 20 proteínas com o número de peptídeos identificados três ou mais vezes maior no imunoprecipitado com anti-pfsr10 em relação ao controle negativo. Nomeamos essas proteínas como proteínas enriquecidas (Tabela 3).

As proteínas imunoprecipitadas com o anticorpo anti-pfsr10 em P. falciparum, exclusivas ou enriquecidas em relação ao controle foram consideradas boas candidatas para interação com pfsr10.

O receptor putativo pfsr10 foi uma das proteínas exclusivamente identificadas na imunoprecipitação, validando a especificidade do anticorpo utilizado (Tabela 2).

Quando acessamos as informações das proteínas candidatas a interagir com pfsr10 no banco de dados do genoma de P. falciparum (PlasmoDB), verificamos que algumas não possuem função predita. A função de outras candidatas é sugerida através de comparações de similaridade a outras proteínas de função conhecida. Algumas poucas possuem evidências experimentais de função.

Algumas das proteínas candidatas a interagir com pfsr10 apresentam domínios transmembrânicos e peptídeos sinal de exportação (Tabela 2, Tabela 3).

As proteínas identificadas podem ser divididas em diversas categorias funcionais, entre elas: proteínas relacionadas à ubiquitinação, à endocitose, à exportação de proteínas, ao dobramento de proteínas, à tradução proteica, à proteólise, à invasão e ao estabelecimento nas células hospedeiras e à replicação do DNA (Tabela 2, Tabela 3). 
Tabela 2 - Proteínas identificadas exclusivamente na imunoprecipitação com anticorpo anti-pfsr10, sem peptídeos identificados no controle negativo. IP em trofozoítos e esquizontes.

(continua)

\begin{tabular}{|c|c|c|c|c|c|c|c|}
\hline $\begin{array}{l}\text { Número } \\
\text { da } \\
\text { proteína }\end{array}$ & $\begin{array}{c}\text { Nome de Proteína de } \\
P \text {. falciparum } \\
\text { Identificada }\end{array}$ & $\begin{array}{l}\text { Número de } \\
\text { Acesso } \\
\text { PlasmodB }\end{array}$ & $\begin{array}{c}\text { Peso } \\
\text { Molecular } \\
\text { da Proteína } \\
(\mathbf{k D a})\end{array}$ & $\begin{array}{l}\text { Peptídeo } \\
\text { Sinal } \\
\text { predito? }\end{array}$ & $\begin{array}{c}\text { Domínios } \\
\text { Transmembrana } \\
\text { preditos? } \\
\text { (número) }\end{array}$ & Possível Função & $\begin{array}{c}\text { Peptídeos } \\
\text { Encontrados } \\
\text { na } \\
\text { Espectrometria } \\
\text { de Massa } \\
\end{array}$ \\
\hline 1 & pfsr10 & PFL0765w & 77 & Sim & $\operatorname{Sim}(7)$ & $\begin{array}{c}\text { Receptor } \\
\text { serpentino }\end{array}$ & 7 \\
\hline 2 & $\begin{array}{l}\text { Fator de iniciação da } \\
\text { tradução eucariótico } 3 \\
\text { subunidade } 6\end{array}$ & PFE1405c & 63 & Não & $\operatorname{Sim}(2)$ & Tradução proteica & 6 \\
\hline 3 & $\begin{array}{l}\text { Fator de iniciação da } \\
\text { tradução eucariótico } 3 \\
\text { subunidade } 8\end{array}$ & PFL0310c & 116 & Não & Não & Tradução proteica & 6 \\
\hline 4 & Proteína conservada & MAL13P1.336 & 79 & Não & Não & Desconhecida & 6 \\
\hline 5 & $\begin{array}{l}\text { Fator de organização e } \\
\text { biogênese do Golgi }\end{array}$ & PFD0880w & 51 & Não & Não & $\begin{array}{c}\text { Organização e } \\
\text { biogênese do Golgi }\end{array}$ & 5 \\
\hline 8 & $\begin{array}{c}\text { Proteína rica em } \\
\text { asparagina clusterizada }\end{array}$ & PFL1745c & 52 & Não & Não & Desconhecida & 4 \\
\hline 9 & ClpB & PF08_0063 & 122 & Sim & $\operatorname{Sim}(1)$ & $\begin{array}{l}\text { Chaperona, desfaz } \\
\text { complexos }\end{array}$ & 4 \\
\hline 10 & $\begin{array}{c}\text { Glutamato tRNA } \\
\text { ligase }\end{array}$ & PF13_0257 & 101 & Não & Não & Tradução proteica & 4 \\
\hline 11 & Proteína conservada & PF14_0191 & 60 & Não & Não & Desconhecida & 4 \\
\hline
\end{tabular}


Tabela 2 - Proteínas identificadas exclusivamente na imunoprecipitação com anticorpo anti-pfsr10, sem peptídeos identificados no controle negativo. IP em trofozoítos e esquizontes.

(continuação)

\begin{tabular}{|c|c|c|c|c|c|c|c|}
\hline $\begin{array}{l}\text { Número } \\
\text { da } \\
\text { proteína }\end{array}$ & $\begin{array}{c}\text { Nome de Proteína de } \\
P \text {. falciparum } \\
\text { Identificada }\end{array}$ & $\begin{array}{l}\text { Número de } \\
\text { Acesso } \\
\text { PlasmodB }\end{array}$ & $\begin{array}{c}\text { Peso } \\
\text { Molecular } \\
\text { da Proteína } \\
(\mathbf{k D a})\end{array}$ & $\begin{array}{l}\text { Peptídeo } \\
\text { Sinal } \\
\text { predito? }\end{array}$ & $\begin{array}{c}\text { Domínios } \\
\text { Transmembrana } \\
\text { preditos? } \\
\text { (número) }\end{array}$ & Possível Função & $\begin{array}{c}\text { Peptídeos } \\
\text { Encontrados } \\
\text { na } \\
\text { Espectrometria } \\
\text { de Massa } \\
\end{array}$ \\
\hline 12 & Isocitrato deidrogenase & PF13_0242 & $53 \mathrm{kDa}$ & Não & Não & $\begin{array}{l}\text { Metabolismo } \\
\text { energético }\end{array}$ & 3 \\
\hline 13 & $\begin{array}{c}\text { Fator de iniciação da } \\
\text { tradução } 3 \text { subunidade } \\
\text { L }\end{array}$ & PFF0590c & 78 & Não & $\operatorname{Sim}(2)$ & Tradução proteica & 2 \\
\hline 14 & $\begin{array}{c}\text { Subunidade do } \\
\text { spliceossomo }\end{array}$ & PFC0375c & 160 & Não & Não & Maturação RNA & 2 \\
\hline 15 & $\begin{array}{l}\text { Glutaminocisteína } \\
\text { sintetase gama }\end{array}$ & PFI0925w & 124 & Não & Não & $\begin{array}{l}\text { Síntese de } \\
\text { glutationa }\end{array}$ & 2 \\
\hline 16 & Proteína conservada & PFI0465c & 72 & Sim & Não & Desconhecida & 2 \\
\hline 17 & Proteína conservada & PFL1115w & 53 & Não & $\operatorname{Sim}(3)$ & Desconhecida & 2 \\
\hline 18 & $\begin{array}{l}\text { Diidropteroato } \\
\text { sintetase }\end{array}$ & PF08_0095 & 83 & Não & Não & Síntese de vitamina & 2 \\
\hline 19 & Proteína conservada & PF08_0091 & 144 & Sim & Não & Desconhecida & 2 \\
\hline 20 & Seril-tRNA sintetase & PF07_0073 & 62 & Não & Não & Síntese proteica & 2 \\
\hline 21 & Alanina tRNA ligase & PF13_0354 & 165 & Sim & Não & Síntese protéica & 2 \\
\hline 22 & DNA ligase I & MAL13P1.22 & 104 & Sim & Não & Replicação DNA & 2 \\
\hline 23 & $\begin{array}{c}\text { Proteína de } \\
\text { remodelamento da } \\
\text { cromatina }\end{array}$ & PF11_0053 & $167 \mathrm{kDa}$ & Não & Não & Transcrição RNA & 2 \\
\hline
\end{tabular}


Tabela 2 - Proteínas identificadas exclusivamente na imunoprecipitação com anticorpo anti-pfsr10, sem peptídeos identificados no controle negativo. IP em trofozoítos e esquizontes.

(continuação)

\begin{tabular}{|c|c|c|c|c|c|c|c|}
\hline $\begin{array}{l}\text { Número } \\
\text { da } \\
\text { proteína }\end{array}$ & $\begin{array}{c}\text { Nome de Proteína de } \\
P \text {. falciparum } \\
\text { Identificada }\end{array}$ & $\begin{array}{l}\text { Número de } \\
\text { Acesso } \\
\text { PlasmodB }\end{array}$ & $\begin{array}{c}\text { Peso } \\
\text { Molecular } \\
\text { da Proteína } \\
\text { (kDa) }\end{array}$ & $\begin{array}{l}\text { Peptídeo } \\
\text { Sinal } \\
\text { predito? }\end{array}$ & $\begin{array}{c}\text { Domínios } \\
\text { Transmembrana } \\
\text { preditos? } \\
\text { (número) }\end{array}$ & Possível Função & $\begin{array}{c}\text { Peptídeos } \\
\text { Encontrados } \\
\text { na } \\
\text { Espectrometria } \\
\text { de Massa } \\
\end{array}$ \\
\hline 24 & $\begin{array}{l}\text { Fator de transcrição } \\
\text { putativo, domínios } \\
\text { AP2 }\end{array}$ & PF10_0075 & 183 & Não & Não & Transcrição RNA & 2 \\
\hline 25 & Proteína conservada & PF14_0649 & 295 & Não & Não & Desconhecida & 2 \\
\hline 26 & $\begin{array}{l}\text { Glicose-6-fosfato } \\
\text { desidrogenase-6- } \\
\text { fosfoglucolactonase }\end{array}$ & PF14_0511 & 107 & Não & Não & Via pentose fosfato & 2 \\
\hline 27 & Sortilina & PF14_0493 & 102 & Não & $\operatorname{Sim}(2)$ & Tráfego vesicular & 2 \\
\hline 28 & Heat shock protein 90 & PF14_0417 & 107 & Sim & Não & $\begin{array}{l}\text { Dobramento } \\
\text { proteico }\end{array}$ & 2 \\
\hline 29 & $\begin{array}{c}\text { Proteína de ligação a } \\
\text { tRNA }\end{array}$ & PF14_0401 & 46 & Não & Não & Tradução proteica & 2 \\
\hline 30 & Succinil Coa sintetase & PF14_0295 & 52 & Não & Não & $\begin{array}{l}\text { Metabolismo } \\
\text { energético }\end{array}$ & 2 \\
\hline 31 & Proteína hipotética & PF14_0186 & 80 & Sim & Não & Desconhecida & 2 \\
\hline 32 & SERA-6 & PFB0335c & 118 & Sim & Não & $\begin{array}{l}\text { Protease, saída de } \\
P . \text { falciparum do } \\
\text { eritrócito }\end{array}$ & 2 \\
\hline 33 & $\begin{array}{l}\text { Aminoacil tRNA } \\
\text { sintetase }\end{array}$ & PFL0670c & 87 & Não & Não & Tradução proteica & 2 \\
\hline 34 & RON-5 & MAL8P1.73 & 134 & Não & Não & Invasão & 1 \\
\hline
\end{tabular}


Tabela 2 - Proteínas identificadas exclusivamente na imunoprecipitação com anticorpo anti-pfsr10, sem peptídeos identificados no controle negativo. IP em trofozoítos e esquizontes.

(continuação)

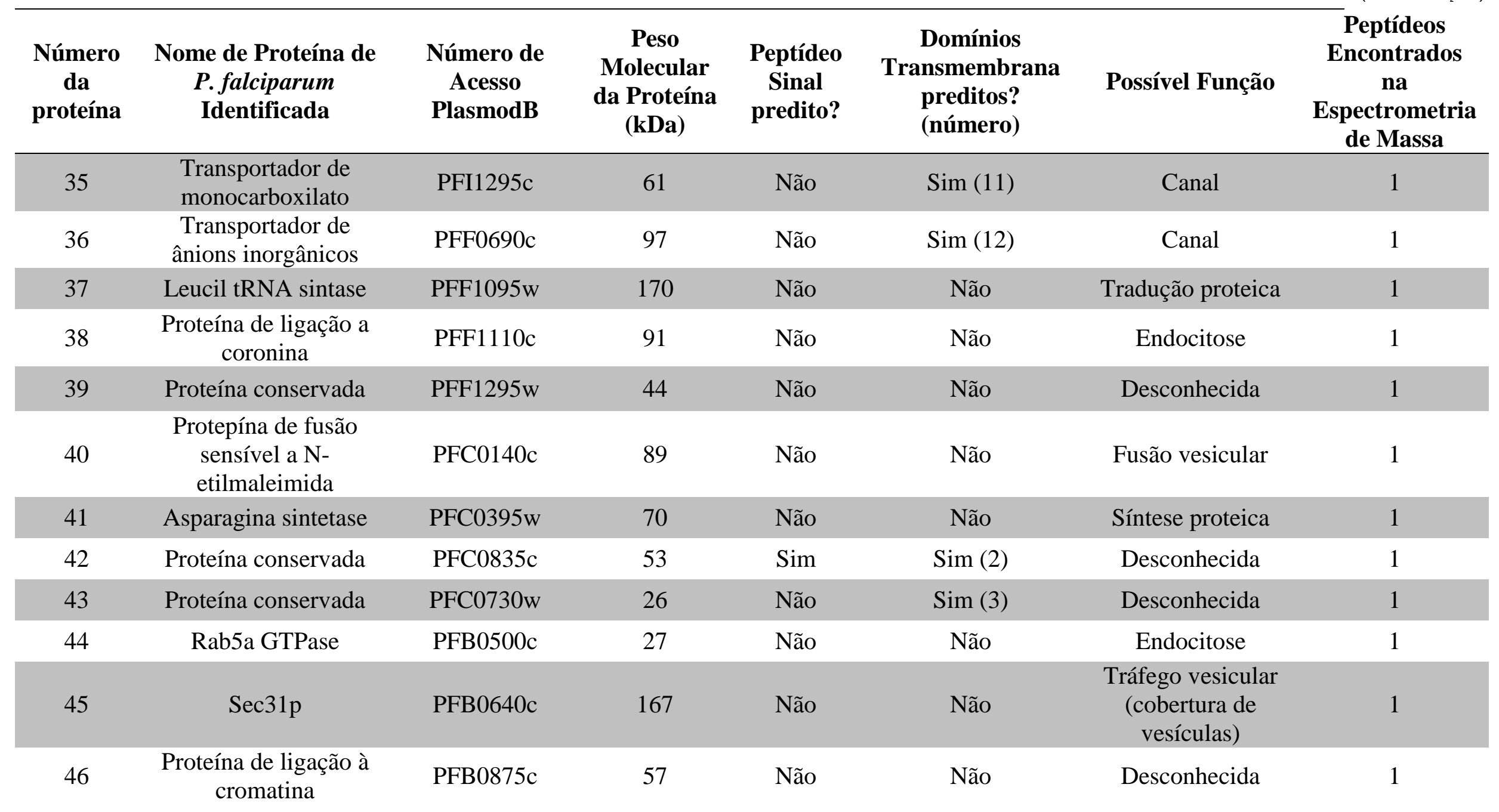


Tabela 2 - Proteínas identificadas exclusivamente na imunoprecipitação com anticorpo anti-pfsr10, sem peptídeos identificados no controle negativo. IP em trofozoítos e esquizontes.

\begin{tabular}{|c|c|c|c|c|c|c|c|}
\hline $\begin{array}{l}\text { Número } \\
\text { da } \\
\text { proteína }\end{array}$ & $\begin{array}{c}\text { Nome de Proteína de } \\
P \text {. falciparum } \\
\text { Identificada }\end{array}$ & $\begin{array}{l}\text { Número de } \\
\text { Acesso } \\
\text { PlasmodB }\end{array}$ & $\begin{array}{c}\text { Peso } \\
\text { Molecular } \\
\text { da Proteína } \\
(\text { kDa })\end{array}$ & $\begin{array}{l}\text { Peptídeo } \\
\text { Sinal } \\
\text { predito? }\end{array}$ & $\begin{array}{c}\text { Domínios } \\
\text { Transmembrana } \\
\text { preditos? } \\
\text { (número) }\end{array}$ & Possível Função & $\begin{array}{c}\text { Peptideos } \\
\text { Encontrados } \\
\text { na } \\
\text { Espectrometria } \\
\text { de Massa } \\
\end{array}$ \\
\hline 47 & Proteína conservada & PFC0315c & 46 & Não & Não & Desconhecida & 1 \\
\hline 48 & $\begin{array}{l}\text { M18 aspartil } \\
\text { aminopeptidase }\end{array}$ & PFI1570c & 66 & Não & Não & $\begin{array}{l}\text { Protease, digestão, } \\
\text { saída de } P \text {. } \\
\text { falciparum do } \\
\text { eritrócito }\end{array}$ & 1 \\
\hline 49 & Fator de splicing & PFI1215w & 71 & Não & Não & Maturação do RNA & 1 \\
\hline 50 & $\begin{array}{l}\text { Subunidade beta do } \\
\text { complexo coatomer }\end{array}$ & PFI0290c & 188 & Não & Não & Tráfego vesicular & 1 \\
\hline 51 & DNAJ & PFE1170w & 62 & Sim & Não & $\begin{array}{l}\text { Dobramento } \\
\text { proteico }\end{array}$ & 1 \\
\hline 54 & $\begin{array}{c}\text { Proteína ribossômica } \\
60 \mathrm{~S}\end{array}$ & PFE0845c & 28 & Não & Não & Tradução proteica & 1 \\
\hline 55 & Fator de splicing & PFE0160c & 38 & Não & Não & Maturação RNA & 1 \\
\hline 56 & $\begin{array}{l}\text { Fosfodiesterase de } \\
\text { esfingomielina }\end{array}$ & PFL1870c & 46 & Não & Não & $\begin{array}{c}\text { Síntese de ácidos } \\
\text { graxos }\end{array}$ & 1 \\
\hline 57 & Proteína conservada & PFL0445w & 167 & Não & Não & Desconhecida & 1 \\
\hline
\end{tabular}


Tabela 2 - Proteínas identificadas exclusivamente na imunoprecipitação com anticorpo anti-pfsr10, sem peptídeos identificados no controle negativo. IP em trofozoítos e esquizontes.

(continuação)

\begin{tabular}{|c|c|c|c|c|c|c|c|}
\hline $\begin{array}{l}\text { Número } \\
\text { da } \\
\text { proteína }\end{array}$ & $\begin{array}{c}\text { Nome de Proteína de } \\
P \text {. falciparum } \\
\text { Identificada }\end{array}$ & $\begin{array}{l}\text { Número de } \\
\text { Acesso } \\
\text { PlasmodB }\end{array}$ & $\begin{array}{c}\text { Peso } \\
\text { Molecular } \\
\text { da Proteína } \\
\text { (kDa) }\end{array}$ & $\begin{array}{l}\text { Peptídeo } \\
\text { Sinal } \\
\text { predito? }\end{array}$ & $\begin{array}{c}\text { Domínios } \\
\text { Transmembrana } \\
\text { preditos? } \\
\text { (número) }\end{array}$ & Possível Função & $\begin{array}{c}\text { Peptídeos } \\
\text { Encontrados } \\
\text { na } \\
\text { Espectrometria } \\
\text { de Massa } \\
\end{array}$ \\
\hline 58 & $\begin{array}{c}\text { Proteína de clivagem } \\
\text { glicina } \mathrm{T}\end{array}$ & PF13_0345 p & 47 & Não & Não & $\begin{array}{l}\text { Metabolismo de } \\
\text { glicina }\end{array}$ & 1 \\
\hline 59 & $\begin{array}{c}\text { Proteína ligadora de } \\
\text { RNA }\end{array}$ & MAL8P1.40 & 32 & Não & Não & Desconhecida & 1 \\
\hline 60 & EBA-175 & MAL7P1.176 & 175 & Sim & Não & Invasão & 1 \\
\hline 61 & $\begin{array}{l}\text { Fator de elongação da } \\
\text { transcrição s-II }\end{array}$ & PF07_0057 & 47 & Não & Não & Transcrição RNA & 1 \\
\hline 62 & Histona $\mathrm{H} 2 \mathrm{~B}$ & PF07_0054 & 138 & Não & Não & $\begin{array}{c}\text { Empacotamento do } \\
\text { DNA }\end{array}$ & 1 \\
\hline 63 & $\begin{array}{c}\text { Proteína de } \\
\text { manutenção de } \\
\text { minicromossomo }\end{array}$ & PF07_0023 & 94 & Não & Não & $\begin{array}{c}\text { Replicação do } \\
\text { DNA }\end{array}$ & 1 \\
\hline 64 & $\begin{array}{c}\text { Hidrolase de } \\
\text { nucleotídeo trifosfato }\end{array}$ & PF13_0273 & 304 & Não & Não & Desconhecida & 1 \\
\hline 65 & Proteína conservada & MAL13P1.194 & 73 & Não & Não & Desconhecida & 1 \\
\hline 66 & $\begin{array}{l}\text { Ribose fosfato } \\
\text { fosfoquinase }\end{array}$ & PF13_0157 & 64 & Não & Não & $\begin{array}{l}\text { Metabolismo } \\
\text { energético }\end{array}$ & 1 \\
\hline 67 & $\begin{array}{c}\text { Componente de 2- } \\
\text { oxoglutarato } \\
\text { dehidrogenase }\end{array}$ & PF13_0121 & 48 & Não & Não & $\begin{array}{l}\text { Metabolismo } \\
\text { energético }\end{array}$ & 1 \\
\hline
\end{tabular}


Tabela 2 - Proteínas identificadas exclusivamente na imunoprecipitação com anticorpo anti-pfsr10, sem peptídeos identificados no controle negativo. IP em trofozoítos e esquizontes.

(conclusão)

\begin{tabular}{|c|c|c|c|c|c|c|c|}
\hline $\begin{array}{l}\text { Número } \\
\text { da } \\
\text { proteína }\end{array}$ & $\begin{array}{c}\text { Nome de Proteína de } \\
P \text {. falciparum } \\
\text { Identificada }\end{array}$ & $\begin{array}{l}\text { Número de } \\
\text { Acesso } \\
\text { PlasmodB }\end{array}$ & $\begin{array}{c}\text { Peso } \\
\text { Molecular } \\
\text { da Proteína } \\
\text { (kDa) }\end{array}$ & $\begin{array}{l}\text { Peptídeo } \\
\text { Sinal } \\
\text { predito? }\end{array}$ & $\begin{array}{c}\text { Domínios } \\
\text { Transmembrana } \\
\text { preditos? } \\
\text { (número) }\end{array}$ & Possível Função & $\begin{array}{c}\text { Peptídeos } \\
\text { Encontrados } \\
\text { na } \\
\text { Espectrometria } \\
\text { de Massa }\end{array}$ \\
\hline 68 & RESA & PF11_0509 & 127 & Não & Não & $\begin{array}{l}\text { Estabelecimento do } \\
\text { parasita no } \\
\text { eritrócito }\end{array}$ & 1 \\
\hline 69 & $\begin{array}{c}\text { Subunidade gama de } \\
\text { coatamer }\end{array}$ & PF11_0463 & 124 & Não & Não & $\begin{array}{l}\text { Tráfego vesicular } \\
\text { (cobertura de } \\
\text { vesículas) }\end{array}$ & 1 \\
\hline 70 & Proteína conservada & PF11_0246 & 154 & $\operatorname{Sim}$ & $\operatorname{Sim}(2)$ & Desconhecida & 1 \\
\hline 71 & RON4 & PF11_0168 & 135 & Sim & Não & Invasão & 1 \\
\hline 72 & Glioxalase I & PF11_0145 & 42 & Não & Não & Detoxificação & 1 \\
\hline 73 & $\begin{array}{l}\text { Fator de transcrição } \\
\text { com domínios AP2 }\end{array}$ & PF11_0091 & 207 & Não & Não & $\begin{array}{c}\text { Transcrição de } \\
\text { RNA }\end{array}$ & 1 \\
\hline 74 & $\begin{array}{c}\text { Proteína rica em } \\
\text { glutamato }\end{array}$ & PF10_0344 & 141 & Sim & Não & Desconhecida & 1 \\
\hline 75 & Proteína perinucleolar & PF10_0278 & 57 & Não & Não & Desconhecida & 1 \\
\hline 76 & $\begin{array}{c}\text { Proteína ribonuclear } \\
\text { pequena U5 }\end{array}$ & PF10_0041 & 143 & Não & Não & Desconhecida & 1 \\
\hline 78 & $\begin{array}{c}\text { Proteína associada ao } \\
\text { cromossomo }\end{array}$ & PFD0685c & 141 & Não & Não & Desconhecida & 1 \\
\hline 79 & $\begin{array}{l}\text { Fator de splicing } \\
\text { putativo }\end{array}$ & MAL13P1.120 & 101 & Não & Não & Maturação RNA & 1 \\
\hline
\end{tabular}


Tabela 3 - Proteínas enriquecidas mais de 3 vezes em relação ao controle negativo na imunoprecipitação utilizando o anticorpo anti-pfsr10 em trofozoitos e esquizontes.

(continua)

\begin{tabular}{|c|c|c|c|c|c|c|c|}
\hline $\begin{array}{l}\text { Número } \\
\text { da } \\
\text { proteína }\end{array}$ & $\begin{array}{c}\text { Nome de } \\
\text { Proteína de } \\
P \text {. falciparum } \\
\text { Identificada }\end{array}$ & $\begin{array}{c}\text { Número de } \\
\text { Acesso } \\
\text { PlasmodB }\end{array}$ & $\begin{array}{l}\text { Peso } \\
\text { Molecular } \\
\quad \text { da } \\
\text { Proteína } \\
\text { (kDa) }\end{array}$ & $\begin{array}{l}\text { Peptídeo } \\
\text { Sinal } \\
\text { predito? }\end{array}$ & $\begin{array}{c}\text { Domínios } \\
\text { Transmembrana } \\
\text { preditos? } \\
\text { (número) }\end{array}$ & $\begin{array}{l}\text { Possível } \\
\text { Função }\end{array}$ & $\begin{array}{c}\text { Número de peptídeos } \\
\text { encontrados na } \\
\text { imunoprecipitação / } \\
\text { Número peptídeos } \\
\text { encontrados no controle } \\
\text { negativo } \\
\end{array}$ \\
\hline 1 & $\begin{array}{c}\text { Fator de } \\
\text { iniciação da } \\
\text { tradução } \\
\text { eucariótico }\end{array}$ & PFE0885w & 84 & Não & Não & $\begin{array}{l}\text { Tradução } \\
\text { proteica }\end{array}$ & $14 / 1$ \\
\hline 2 & $\begin{array}{c}\text { Fator de } \\
\text { iniciação da } \\
\text { tradução } \\
\text { eucariótico } 3 \\
\text { subunidade } 7\end{array}$ & PF10_0077 & 63 & Não & Não & $\begin{array}{l}\text { Tradução } \\
\text { proteica }\end{array}$ & $9 / 1$ \\
\hline 3 & $\begin{array}{c}\text { Antígeno } \\
\text { associado a } \\
\text { membrana do } \\
\text { eritrócito } 2\end{array}$ & MAL7P1.12 & 263 & Não & $\operatorname{Sim}(2)$ & Desconhecida & $7 / 1$ \\
\hline 4 & $\begin{array}{c}\text { Proteína com } \\
\text { similaridade a } \\
\text { dinamina }\end{array}$ & PF11_0465 & 96 & Não & Não & $\begin{array}{l}\text { Tráfego } \\
\text { vesicular }\end{array}$ & $7 / 1$ \\
\hline 5 & $\begin{array}{c}\text { Treonina } \\
\text { tRNA ligase } \\
\text { putativa }\end{array}$ & PF11_0270 & 119 & Sim & Não & $\begin{array}{c}\text { Tradução } \\
\text { proteica }\end{array}$ & $19 / 3$ \\
\hline 6 & $\begin{array}{c}\text { DNA helicase } \\
\text { dependente de } \\
\text { ATP }\end{array}$ & PF13_0330 & 55 & Não & Não & $\begin{array}{c}\text { Replicação de } \\
\text { DNA }\end{array}$ & $6 / 1$ \\
\hline
\end{tabular}


Tabela 3 - Proteínas enriquecidas mais de 3 vezes em relação ao controle negativo na imunoprecipitação utilizando o anticorpo anti-pfsr10 em trofozoitos e esquizontes.

(continuação)

\begin{tabular}{|c|c|c|c|c|c|c|c|}
\hline $\begin{array}{l}\text { Número } \\
\text { da } \\
\text { proteína }\end{array}$ & $\begin{array}{c}\text { Nome de } \\
\text { Proteína de } \\
P \text {. falciparum } \\
\text { Identificada }\end{array}$ & $\begin{array}{c}\text { Número de } \\
\text { Acesso } \\
\text { PlasmodB }\end{array}$ & $\begin{array}{c}\text { Peso } \\
\text { Molecular } \\
\text { da } \\
\text { Proteína } \\
\text { (kDa) }\end{array}$ & $\begin{array}{c}\text { Peptídeo } \\
\text { Sinal } \\
\text { predito? }\end{array}$ & $\begin{array}{c}\text { Domínios } \\
\text { Transmembrana } \\
\text { preditos? } \\
\text { (número) }\end{array}$ & $\begin{array}{l}\text { Possível } \\
\text { Função }\end{array}$ & $\begin{array}{c}\text { Número de peptídeos } \\
\text { encontrados na } \\
\text { imunoprecipitação / } \\
\text { Número peptídeos } \\
\text { encontrados no controle } \\
\text { negativo }\end{array}$ \\
\hline 7 & $\begin{array}{c}\text { U2 snRNP } \\
\text { fator auxiliary, } \\
\text { subunidade } \\
\text { pequena } \\
\text { PF11_0200 } 35 \\
\text { kDa } 0 / 0\end{array}$ & PF11_0200 & 35 & Não & Não & Desconhecida & $6 / 1$ \\
\hline 8 & Actina II & PF14_0124 & 42 & Não & Não & Invasão & $26 / 5$ \\
\hline 9 & Miosina A & PF13_0233 & 92 & Não & Não & Invasão & $5 / 1$ \\
\hline 10 & $\begin{array}{c}\text { Porteína } \\
\text { conservada }\end{array}$ & MAL8P1.103 & 71 & Não & Não & Desconhecida & $8 / 2$ \\
\hline 11 & $\begin{array}{c}\text { Proteina } \\
\text { ligante de } \\
\text { poliadenilato }\end{array}$ & $\begin{array}{c}\text { MAL13P1.30 } \\
3\end{array}$ & 48 & Não & Não & Desconhecida & $4 / 1$ \\
\hline
\end{tabular}


Tabela 3 - Proteínas enriquecidas mais de 3 vezes em relação ao controle negativo na imunoprecipitação utilizando o anticorpo anti-pfsr10 em trofozoitos e esquizontes.

(continuação)

\begin{tabular}{|c|c|c|c|c|c|c|c|}
\hline $\begin{array}{l}\text { Número } \\
\text { da } \\
\text { proteína }\end{array}$ & $\begin{array}{c}\text { Nome de } \\
\text { Proteína de } \\
\text { P.falciparum } \\
\text { Identificada }\end{array}$ & $\begin{array}{l}\text { Número de } \\
\text { Acesso } \\
\text { PlasmodB }\end{array}$ & $\begin{array}{c}\text { Peso } \\
\text { Molecular } \\
\text { da } \\
\text { Proteína } \\
\text { (kDa) }\end{array}$ & $\begin{array}{l}\text { Peptídeo } \\
\text { Sinal } \\
\text { predito? }\end{array}$ & $\begin{array}{c}\text { Domínios } \\
\text { Transmembrana } \\
\text { preditos? } \\
\text { (número) }\end{array}$ & $\begin{array}{l}\text { Possível } \\
\text { Função }\end{array}$ & $\begin{array}{c}\text { Número de peptídeos } \\
\text { encontrados na } \\
\text { imunoprecipitação / } \\
\text { Número peptídeos } \\
\text { encontrados no controle } \\
\text { negativo }\end{array}$ \\
\hline 12 & $\begin{array}{c}\text { Fator de } \\
\text { iniciação da } \\
\text { tradução } \\
\text { eucariótico } 3 \\
\text { subunidade } 10\end{array}$ & PFL0625c & 166 & Não & Não & $\begin{array}{l}\text { Tradução } \\
\text { proteica }\end{array}$ & $7 / 2$ \\
\hline 13 & $\begin{array}{l}\text { ATPase de } \\
\text { divisão de } \\
\text { ciclo celular }\end{array}$ & PF07_0047 & 142 & Sim & $\operatorname{Sim}(1)$ & $\begin{array}{l}\text { Controle do } \\
\text { ciclo celular, } \\
\text { entre outros }\end{array}$ & $3 / 1$ \\
\hline 14 & CDPK1 & PFB0815w & 60 & Não & Não & Invasão & $3 / 1$ \\
\hline 15 & $\begin{array}{l}\text { Fator de } \\
\text { splicing } \\
\text { putativo }\end{array}$ & PFE0865c & 35 & Não & Não & $\begin{array}{c}\text { Maturação } \\
\text { RNA }\end{array}$ & $3 / 1$ \\
\hline 16 & $\begin{array}{c}\text { Proteína } \\
\text { associada ao } \\
\text { poro nuclear }\end{array}$ & PFE0380c & 63 & Não & Não & Desconhecida & $3 / 1$ \\
\hline 17 & $\begin{array}{c}\text { Proteína } \\
\text { conservada }\end{array}$ & PFL1415w & 117 & Sim & $\operatorname{Sim}(1)$ & Desconhecida & $3 / 1$ \\
\hline
\end{tabular}


Tabela 3 - Proteínas enriquecidas mais de 3 vezes em relação ao controle negativo na imunoprecipitação utilizando o anticorpo anti-pfsr10 em trofozoítos e esquizontes

(conclusão)

\begin{tabular}{|c|c|c|c|c|c|c|c|}
\hline $\begin{array}{l}\text { Número } \\
\text { da } \\
\text { proteína }\end{array}$ & $\begin{array}{c}\text { Nome de } \\
\text { Proteína de } \\
P . \text { falciparum } \\
\text { Identificada }\end{array}$ & $\begin{array}{l}\text { Número de } \\
\text { Acesso } \\
\text { PlasmodB }\end{array}$ & $\begin{array}{c}\text { Peso } \\
\text { Molecular } \\
\text { da } \\
\text { Proteína } \\
\text { (kDa) }\end{array}$ & $\begin{array}{c}\text { Peptídeo } \\
\text { Sinal } \\
\text { predito? }\end{array}$ & $\begin{array}{c}\text { Domínios } \\
\text { Transmembrana } \\
\text { preditos? } \\
\text { (número) }\end{array}$ & $\begin{array}{l}\text { Possível } \\
\text { Função }\end{array}$ & $\begin{array}{c}\text { Número de peptídeos } \\
\text { encontrados na } \\
\text { imunoprecipitação / } \\
\text { Número peptídeos } \\
\text { encontrados no controle } \\
\text { negativo }\end{array}$ \\
\hline 18 & $\begin{array}{c}\text { Enzima } \\
\text { ativadora de } \\
\text { ubiquitina E1 }\end{array}$ & PFL1245w & 132 & Não & Não & $\begin{array}{l}\text { Diversas } \\
\text { funções }\end{array}$ & $3 / 1$ \\
\hline 19 & $\begin{array}{c}\text { Proteína } \\
\text { conservada }\end{array}$ & PFL0280c & 39 & Não & Não & Desconhecida & $6 / 2$ \\
\hline 20 & $\begin{array}{c}\text { Lisil tRNA } \\
\text { sintetase }\end{array}$ & PF13_0262 & 68 & Não & Não & $\begin{array}{c}\text { Tradução } \\
\text { proteica }\end{array}$ & $12 / 4$ \\
\hline
\end{tabular}




\subsubsection{Proteínas relacionadas a tradução, via exocítica e via endocítica}

Diversas proteínas que fazem parte da maquinaria da tradução de RNA foram encontradas, dentre elas fatores de iniciação da tradução (Tabela 2 , proteínas 2 e 3).

Dentre as proteínas relacionadas com a via exocítica e/ou endocítica destacamos os seguintes fatores: proteína semelhante à dinamina (Tabela 3, proteína 4), a proteína de fusão sensível a N-etilmaleimida (Tabela 2, proteína 40), Sec31p (Tabela 2, proteína 45), Rab5a GTPase (Tabela 2, proteína 44 ) e inibidor de associação Rab-GDP (Tabela 2 proteína 6).

A proteína Sec31p participa do complexo COPII, que cobre vesículas nascentes do retículo endoplasmático que irão se fundir ao complexo de Golgi (Tang et al., 2000).

A dinamina, uma GTPase classicamente envolvida na formação da vesícula endocítica, destacando a vesícula em formação da membrana plasmática. A dinamina também participa da via exocítica, participando na formação de vesículas a partir das cisternas do trans-Golgi (revisado em Ramachandran 2011). A enzima possui um domínio PH (homologia a pleckstrina) para interação com a membrana plasmática, um domínio intermediário de associação com outras subunidades de dinamina, um domínio N-terminal com função GTPase e um domínio C-terminal de ligação a proteínas acessórias para direcionamento a diversos lugares de ação (revisado em Ramachandran, 2011).

A proteína de fusão sensível a N-etilmaleimida, cuja unidade funcional é um homotrímero, promove a fusão de vesículas a membranas, tanto no transporte entre retículo endoplasmático e complexo de Golgi quanto entre cisternas do complexo de Golgi ou entre o complexo de Golgi e membrana plasmática através da hidrólise de ATP (Whiteheart e Hart, 1994). A função da proteína é a de promover a separação entre receptores proteicos de adesão de proteína de fusão sensível a N-etilmaleimida (SNARES), receptores estes localizados nas membranas alvo (t-SNARES) e vesículas (v-SNARES), evento que ocorre pouco antes da fusão da vesícula com a membrana (Kuner et al., 2008).

A Rab5a GTPase regula a fusão de vesículas endocíticas ao endossomo inicial, assim como a fusão entre endossomos iniciais (revisado em Olkkonen e Stenmark, 1997) ao passo que a proteína inibidora de associação Rab-GDP diminui a velocidade de desligamento de diversas Rabs a GDP, o que desliga as Rabs de membranas (Ullrich et al., 1993). 


\subsubsection{Proteína relacionada à ubiquitinação}

Uma proteína relacionada com ubiquitinação também foi encontrada: a enzima ativadora de ubiquitina E1 (Tabela 3, proteína 18). A ubiquitinação de proteínas possui diversas funções celulares, incluindo participação na endocitose de receptores na dessensibilização, degradação proteica e tráfego de proteínas (revisado em Acconcia et al., 2009).

\subsubsection{Proteínas relacionadas à invasão e estabelecimento na célula hospedeira}

Proteínas possivelmente relacionadas à invasão do eritrócito e estabelecimento na célula hospedeira também foram identificadas. Estas incluem a M18 aspartil aminopeptidase (Tabela 2 proteína 48), EBA175 (Tabela 2 proteína 60), RESA (Tabela 2, proteína 68), Miosina A (Tabela 3, proteína 9), CDPK1 (Tabela 3 proteína 14), RON-4 (Tabela 2 proteína 71), RON-5 (Tabela 2 proteína 34) e SERA-6 (Tabela 2 proteína 32).

A M18 aspartil aminopeptidase é uma metaloprotease que pode participar na digestão da hemoglobina no vacúolo digestivo de P. falciparum, porém pode possuir outras funções, como ativação de proteínas pela remoção das porções $\mathrm{N}$-terminais e fragilização de espectrina, que sustenta a membrana plasmática do eritrócito, participando no processo de ruptura e evasão dos merozoítos do eritrócito (Lauterbach e Coetzer, 2008). É também possível que a protease participe no processo de invasão do eritrócito, já que inibidores de metaloproteases inibem esse processo (Lauterbach e Coetzer, 2008).

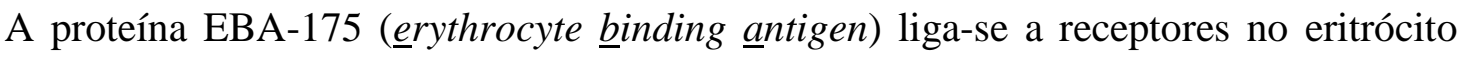
permitindo a interação da porção apical do merozoíto com o eritrócito (Duraisingh et al., 2003).

A proteína RESA (ring-infected erythrocyte surface antigen) interage com a espectrina do eritrócito, estabilizando a membrana plasmática e impedindo a invasão de novos merozoítos (Pei et al., 2007).

A proteína Miosina A é necessária para a invasão de células hospedeiras por Toxoplasma gondii (Meissner et al., 2002) um parasita evolutivamente próximo a $P$. falciparum, o que sugere uma função parecida em Plasmodium falciparum.

A proteína CDPK1 (calcium dependent protein kinase 1) localiza-se na periferia de merozoítos de P. falciparum e, portanto, possui uma localização que permite interagir com a 
maquinaria relacionada à invasão de eritrócitos (Green et al., 2008). De fato, CDPK1 é capaz de fosforilar componentes da maquinaria de invasão de eritrócitos que interagem com o complexo motor de Miosina A (Green et al., 2008).

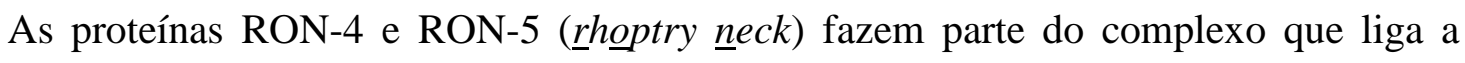
membrana do eritrócito à membrana do parasita, permitindo a invasão do eritrócito (Curtidor et al., 2011).

A proteína SERA-6 ( serine $\underline{\text { rich }} \underline{\text { surface }}$ antigen) é uma cisteíno protease que localiza no vacúolo parasitóforo de estágios intraeritrocíticos do parasita. Anticorpos contra SERA impedem a saída de parasitas do eritrócito ao final da esquizogonia (Pang et al., 1999).

\subsubsection{Chaperonas}

Dentro da categoria foram identificadas a proteína ClpB (Tabela 2 proteína 9) e a proteína hsp90 (Tabela 2 proteína 28).

A proteína ClpB putativa (peptidase caseinolítica B) é uma chaperona com domínio ATPase da superfamília AAA (ATPases relacionadas a diversas funções celulares). A ClpB está envolvida na desagregação de agregados proteicos insolúveis e é importante para a sobrevivência celular em caso de stress, funcionando em conjunto com hsp70 (revisado em Doyle e Wickner, 2009). A chaperona é composta por seis subunidades idênticas que formam um canal central por onde proteínas desagregadas linearizadas pela chaperona são inseridas para posterior redobramento na configuração nativa ou degradação por componentes proteolíticos (revisado em Doyle e Wickner, 2009).

Proteínas hsp90, agindo em conjunto com cochaperonas ajudam no dobramento de proteínas através de ligação a domínios hidrofóbicos evitando interações não nativas, na desagregação de complexos proteicos e no encaminhamento de proteínas mal dobradas para degradação via proteassomo (revisado em Taipale et al., 2010).

\subsubsection{Outras proteínas}

Uma ATPase da família cdc48 foi encontrada, ATPase do tipo cdc (Tabela 3 proteína 13). A proteína em questão possui similaridade com uma ATPase transicional de retículo endoplasmático (VCP), que funciona nos processos celulares de fusão vesicular, degradação proteica e controle do ciclo celular (revisado em Wang et al., 2004). VCP age juntamente com 
cdc48 no controle do ciclo celular (revisado em Wang et al., 2004). A proteína cdc48 participa na desmontagem do fuso mitótico no final da anáfase, com dois mecanismos sugeridos de ação: apresentação de proteínas ubiquitinadas do fuso mitótico ao proteassomo para degradação ou rompimento das ligações entre proteínas e microtúbulos do fuso, uma função chaperona (revisado em Cheeseman e Desai, 2004).

Algumas relacionadas à replicação e transcrição do DNA foram identificadas: helicases (Tabela 3 proteína 6) e fatores de transcrição (Tabela 2 proteína 24). Proteínas relacionadas ao metabolismo energético também foram encontradas (Tabela 2 proteína 12).

\subsubsection{Imunoprecipitação de parceiros moleculares de pfsr10 após estímulo com ATP}

A fim de verificar se eventualmente, após o estímulo dos parasitas com ATP, havia alteração na qualidade ou quantidade das proteínas que interagiam com o receptor putativo pfsr10, executamos imunoprecipitação do receptor após estímulo com ATP, ou na ausência do estímulo.

Após corrida em gel de poliacrilamida e coloração com coomassie, foram observadas algumas bandas no gel (Figura 24), com tamanhos de $100 \mathrm{kDa}, 70 \mathrm{kDa}$, duas bandas por volta de $55 \mathrm{kDa}, 25 \mathrm{kDa}$ e $20 \mathrm{kDa}$. A banda mais intensa de $55 \mathrm{kDa}$ é a cadeia pesada de anticorpo. A presença dessa cadeia revela que houve ligação do anticorpo à proteína. A banda de $20 \mathrm{kDa}$ (Figura 24, seta 3) foi recortada e identificada por espectrometria de massa, porém a única proteína identificada foi a cadeia leve de IgG. Assim, decidimos identificar as bandas de $100 \mathrm{kDa}$ e $70 \mathrm{kDa}$, que se encontram bastante distantes da cadeia pesada de $\operatorname{IgG}$ (55 kDa, Figura 24). Essas bandas são identificadas no gel como banda 1 e banda 2, respectivamente (Figura 24, setas 1 e 2). Recortamos e identificamos as proteínas das bandas tanto no controle quanto no tratamento com ATP (Tabela 4).

Figura 24 - Imunoprecipitação de proteínas de P. falciparum com anti-pfsr10 após estímulo com ATP.

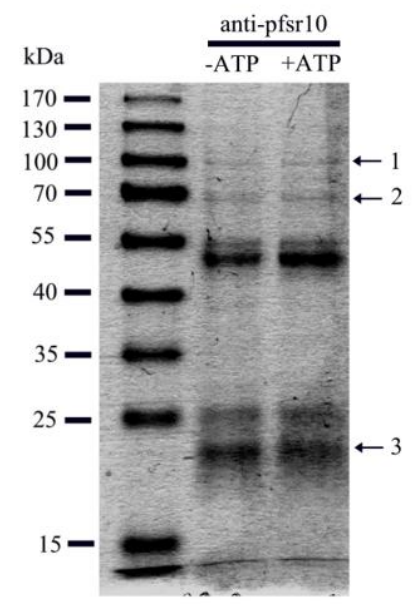


Bandas enviadas para análise de espectrometria de massa estão indicadas pelas setas 1, 2 e 3 . As setas indicam bandas enviadas nos dois tratamentos (sem ATP e com $50 \mu \mathrm{M}$ de ATP). IP em trofozoítos e esquizontes.

Tabela 4 - Proteínas identificadas em imunoprecipitado com anticorpo anti-pfsr10 em $P$. falciparum.

\begin{tabular}{|c|c|c|c|c|c|}
\hline $\begin{array}{c}\text { Proteína de } P \text {. } \\
\text { falciparum } \\
\text { identificada }\end{array}$ & $\begin{array}{l}\text { Número de } \\
\text { peptídeos } \\
\text { identificados } \\
\text { (-ATP/+ATP) }\end{array}$ & $\begin{array}{l}\text { Número de } \\
\text { acesso } \\
\text { PlasmoDB }\end{array}$ & $\begin{array}{c}\text { Domínios } \\
\text { Conservados }\end{array}$ & $\begin{array}{c}\text { Tamanho } \\
\text { predito }\end{array}$ & $\begin{array}{l}\text { Possível } \\
\text { Função }\end{array}$ \\
\hline $\begin{array}{l}\text { Proteína Heat } \\
\text { Shock } 86\end{array}$ & $25 / 26$ & PF07_0029 & $\begin{array}{l}\text { HATPaseC, } \\
\text { domínios } \\
\text { HSP90 }\end{array}$ & $86 \mathrm{kDa}$ & Chaperona \\
\hline $\begin{array}{l}\text { Treonina tRNA } \\
\text { ligase, putativa }\end{array}$ & $5 / 10$ & PF11_0270 & $\begin{array}{l}\text { Domínios } \\
\text { tRNA ligase }\end{array}$ & $120 \mathrm{kDa}$ & Síntese proteica \\
\hline $\begin{array}{c}\text { Proteína de } \\
\text { ligação a RNA, } \\
\text { putativa }\end{array}$ & $3 / 8$ & PFF_0250w & $\begin{array}{c}\text { Domínio KH, } \\
\text { processamento } \\
\text { RNA }\end{array}$ & $86 \mathrm{kDa}$ & $\begin{array}{c}\text { Processamento } \\
\text { de RNA }\end{array}$ \\
\hline $\begin{array}{c}\text { Precursor } \\
\text { homólogo de } \\
\text { endoplasmina, } \\
\text { putativo }\end{array}$ & $0 / 1$ & PFL1070C & $\begin{array}{l}\text { HATPaseC, } \\
\text { domínios } \\
\text { HSP90 }\end{array}$ & $95 \mathrm{kDa}$ & $\begin{array}{l}\text { Chaperona, } \\
\text { tampão de } \\
\text { cálcio }\end{array}$ \\
\hline $\begin{array}{l}\text { Proteína } \\
\text { conservada de } \\
\text { Plasmodium }\end{array}$ & $25 / 26$ & MAL8P1.103 & DUF2009 & $71 \mathrm{kDa}$ & Desconhecida \\
\hline $\begin{array}{c}\text { Homólogo de } \\
\text { Heat Shock } 70 \\
\text { (HSP70) }\end{array}$ & $20 / 21$ & PFI0875w & PTZ00009 & $72 \mathrm{kDa}$ & Chaperona \\
\hline $\begin{array}{l}\text { Proteína Heat } \\
\text { Shock } 70\end{array}$ & $10 / 19$ & PF08_0054 & PTZ00009 & $74 \mathrm{kDa}$ & Chaperona \\
\hline $\begin{array}{c}\text { Proteína } \\
\text { conservada de } \\
\text { Plasmodium }\end{array}$ & $13 / 13$ & PFC0500w & Não encontrado & $73 \mathrm{kDa}$ & Desconhecida \\
\hline $\begin{array}{c}\text { Proteína } \\
\text { conservada de } \\
\text { Plasmodium }\end{array}$ & $0 / 2$ & PF14_0191 & Não encontrado & $60 \mathrm{kDa}$ & Desconhecida \\
\hline Aconitase & $1 / 0$ & PF13_0229 & AcnA_IRP & $103 \mathrm{kDa}$ & $\begin{array}{c}\text { Metabolismo } \\
\text { energético } \\
\text { (ciclo de Krebs) }\end{array}$ \\
\hline
\end{tabular}

(-) ATP: Parasitas sem exposição a $50 \mu \mathrm{M}$ ATP. (+) ATP: parasitas com exposição a $50 \mu \mathrm{M}$ ATP. As quatro primeiras proteínas foram identificadas na banda 1 do gel $(100 \mathrm{kDa})$. As demais proteínas foram identificadas na banda 2 do gel $(70 \mathrm{kDa})$. IP em trofozoítos e esquizontes. 


\subsection{Receptor Serpentino putativo PFSR25}

\subsubsection{Expressão proteica e localização de pfsr25 em fases sanguíneas de Plasmodium} falciparum: o receptor putativo é mais expresso nas fases de trofozoíto e esquizonte do ciclo intraeritrocítico

A fim de identificar a expressão de pfsr25 ao longo do ciclo intraeritrocítico, sincronizamos parasitas $P$. falciparum e seguimos a fase dos parasitas através de lâminas. Submetemos alíquotas de parasitas, retirados nos tempos pós-sincronização indicados, a western blot (Figura 25). A proteína pfsr25 foi detectada, especificamente, em uma altura de aproximadamente $45 \mathrm{kDa}$, o que condiz com seu tamanho predito (Figura 25). Além disso, a quantidade de pfsr25 expressa no estágio de anel foi menor que a quantidade de pfsr25 detectada nos estágios tardios (Figura 25).

Figura 25 - Detecção de pfsr25 em P. falciparum através de western blot.

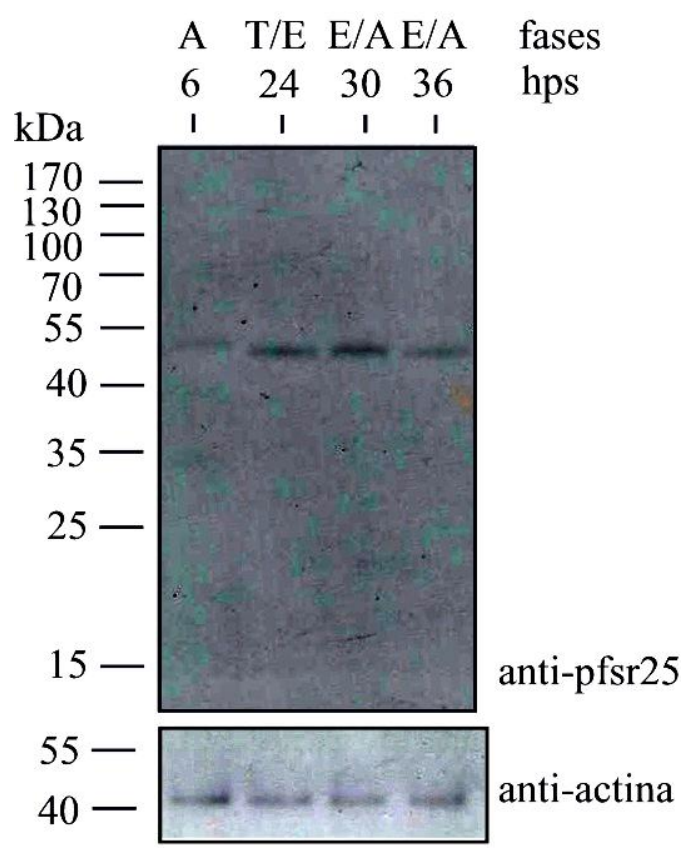

Detecção de pfsr25 em fases do ciclo intraeritrocitico de $P$. falciparum. Parasitas isolados de $P$. falciparum foram sincronizados e lisados nas horas pós sincronização (hps) indicadas. A proteína das amostras foi quantificada. Após SDS-PAGE, transferência para membrana de PVDF e bloqueio, a membrana foi incubada com anti-pfsr25 de coelho (1:2000) e anti- IgG de coelho conjugado a HRP. O controle de carregamento de proteína no gel foi efetuado com anti-actina (1:5000). Os estágios observados através de lâminas em cada extração estão indicados. A: anel, T: trofozoíto, E: esquizonte.

Utilizando anticorpo anti-pfsr25 desenvolvido em coelho verificamos, através de experimentos de imunofluorescência, que houve detecção de pfsr25 nas fases de trofozoíto e 
esquizonte (Figura 26), enquanto na fase jovem de anel não detectamos o receptor putativo (Figura 26), o que está de acordo com o observado através de western blot (Figura 25).

Em merozoítos, detectamos pfsr25, porém fracamente (Figura 26). A fim de verificar a localização de pfsr25 em relação à membrana de $P$. falciparum efetuamos experimentos de imunofluorescência utilizando anticorpo contra a proteína msp1, que está localizada na membrana plasmática durante fases maduras do desenvolvimento (Dluzewski et al., 2008). Verificamos, assim, que há colocalização parcial de pfsr25 com a membrana plasmática dos parasitas durante fases maduras do desenvolvimento (Figura 27).

Figura 26 - Detecção através de imunofluorescência da expressão de pfsr25 em fases do ciclo eritrocítico de $P$. falciparum.

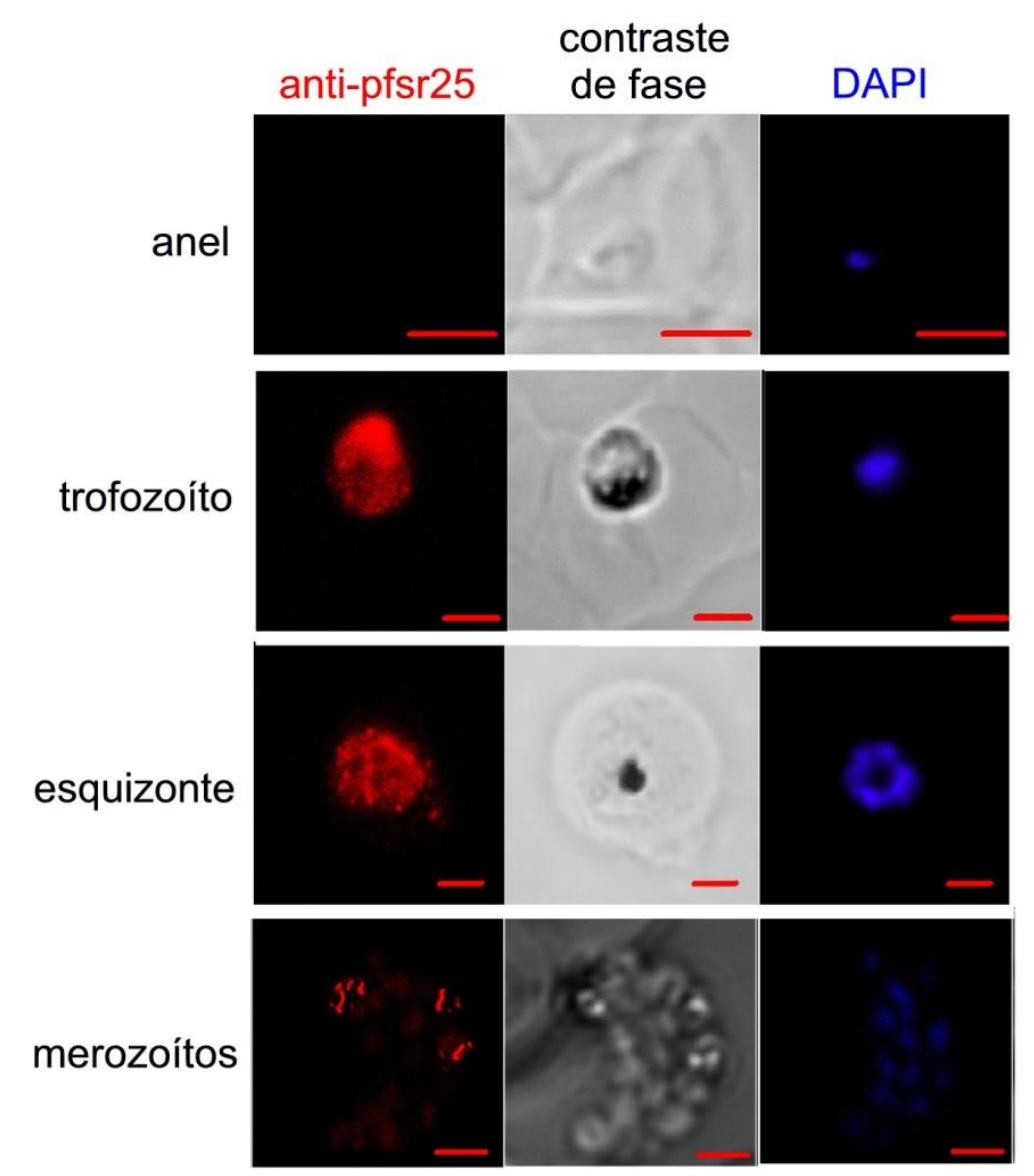

Hemácias infectadas fixadas e bloqueadas foram incubadas com anti-pfsr25 desenvolvido em coelho (1:100) e anticorpo secundário anti-IgG coelho ligado a Alexa 546. Para diferenciar fases intraeritrocíticas, o DNA dos parasitas foi marcado com DAPI. Traços vermelhos: escala $(2 \mu \mathrm{m})$. 
Figura 27 - Localização subcelular de pfsr25 em fase madura de $P$. falciparum.

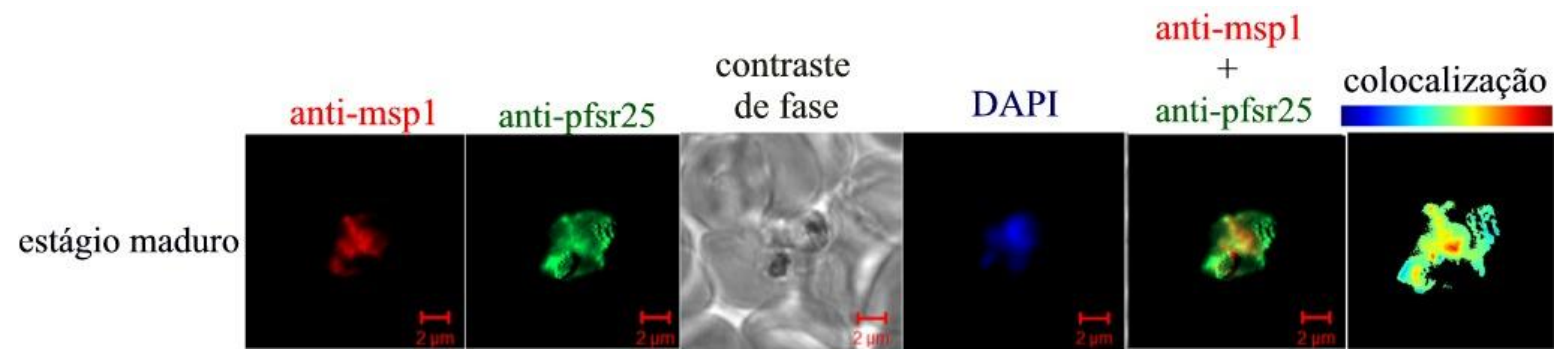

Hemácias infectadas fixadas e bloqueadas foram incubadas com anti-pfsr 25 desenvolvido em coelho (1:100), anti-msp1 desenvolvido em camundongo (1:50) e anticorpos secundários anti-IgG de coelho ligado a Alexa 488 e anti-IgG de camundongo ligado a Alexa 546. Colocalização entre msp1 e pfsr25 foi analisada com programa ImageJ, plugin colocalization Colormap. Cores próximas ao vermelho indicam boa colocalização (barra). O DNA dos parasitas foi marcado com DAPI.

\subsubsection{Anticorpo anti-pfsr25 não altera invasão de hemácias por P. falciparum}

Com a finalidade de verificar se o anticorpo anti-pfsr25 poderia interferir com o a progressão do ciclo eritrocítico de $P$. falciparum, incubamos esquizontes segmentados com diversas concentrações do anticorpo.

Tendo em vista que pfsr25 é expresso na membrana plasmática de $P$. falciparum na fase de esquizonte (Figura 28), momento no qual a célula hospedeira é bastante permeável a macromoléculas (Kutner et al., 1983) e anti-pfsr25 foi desenvolvido contra uma porção Nterminal da proteína, é esperado que o anticorpo tenha acesso a pfsr25. Contamos a parasitemia em um citômetro de fluxo 24 h após a invasão. Não foram encontradas diferenças de parasitemia ou porcentagem de fases em relação ao controle (Figura 28 A-C). 
Figura 28 - Distribuição de fases e parasitemia após invasão de hemácias por $P$. falciparum em presença de diversas concentrações de anticorpo anti-pfsr 25.

A
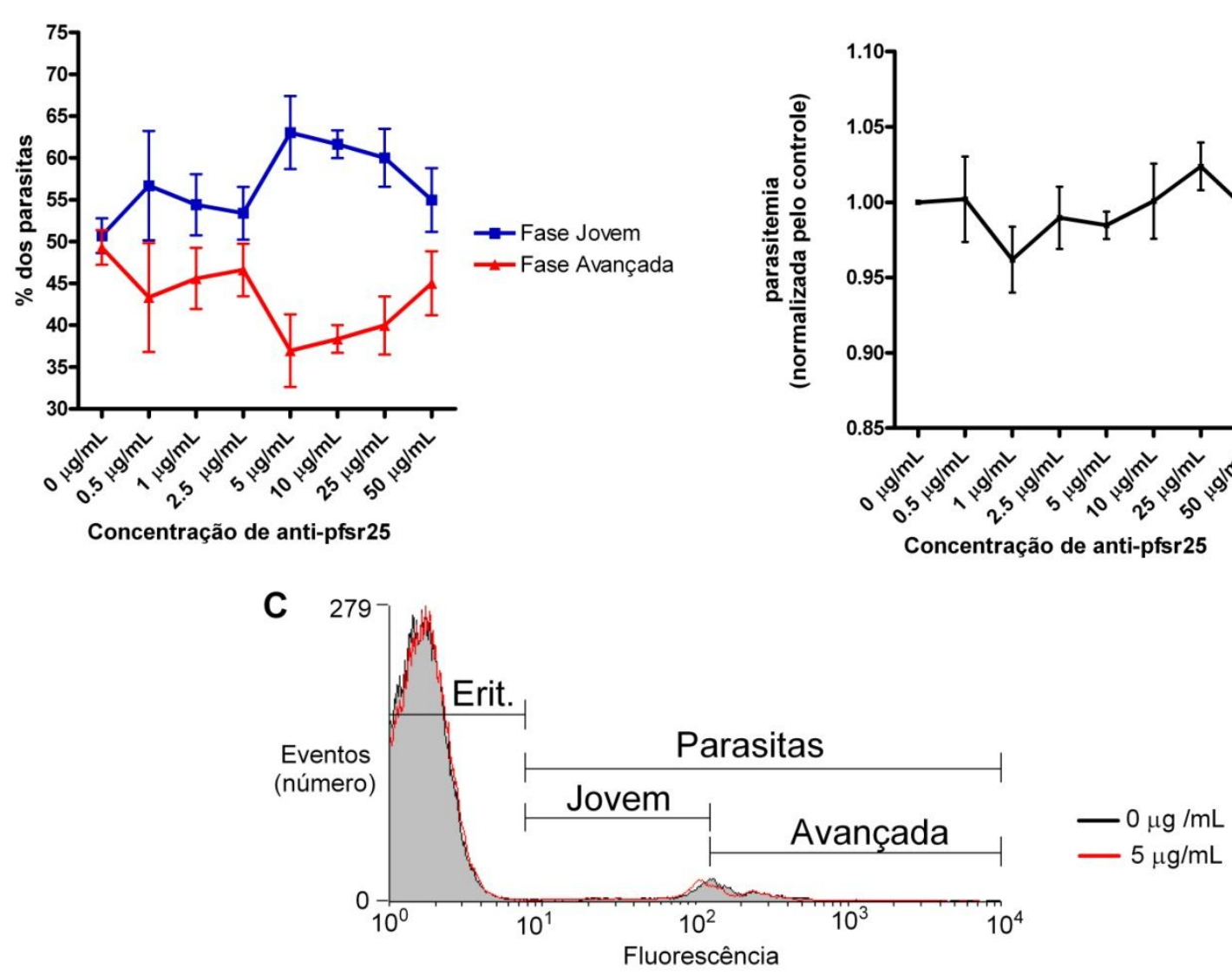

Esquizontes tardios de P. falciparum foram incubados com anticorpo em meio de cultura sem soro, durante $6 \mathrm{~h}$. $\mathrm{O}$ soro foi acrescentado e parasitas cultivados durante $18 \mathrm{~h}$ antes de contagem de parasitemia utilizando citômetro de fluxo. A: proporção de fases intraeritrocíticas jovens e avançadas. B: Parasitemia, C: Histogramas representativos sobrepostos sem anticorpo e com $5 \mu \mathrm{g} / \mathrm{mL}$ de antipfsr25. Erit.: eritrócitos. Os resultados são de três experimentos independentes. Dados estão indicados como média terro padrão. Dados foram estatisticamente analisados por One-Way ANOVA e pós-teste de Newman-Keuls.

\subsubsection{Em sistema heterólogo, pfsr25 é identificada como proteína de aproximadamente 40} kDa e colocaliza parcialmente com a membrana plasmática

A fim de executar ensaios funcionais, transfectamos PFSR25 em sistema heterólogo. Células HEK293T-PFSR25 foram submetidas a ensaios de imunocitoquímica. A proteína pfsr25 foi detectada em maior ou menor grau, através de imunofluorescência, em parte da população de células HEK293T-PFSR10 (Figura 29) enquanto células não transfectadas com o receptor não apresentam fluorescência evidente (dados não mostrados). Através de tomada de imagens com microscópio confocal e uso de aglutinina, um marcador de membrana plasmática, demonstramos que pfsr25 e aglutinina colocalizam parcialmente (Figura 30). 
Além disso, observamos que houve uma variação fenotípica no que diz respeito ao grau de localização entre pfsr25 e membrana plasmática (i.e., algumas células apresentaram mais colocalização que outras, Figura 30).

Figura 29 - Proporção de células HEK293T com expressão de pfsr25 identificada.
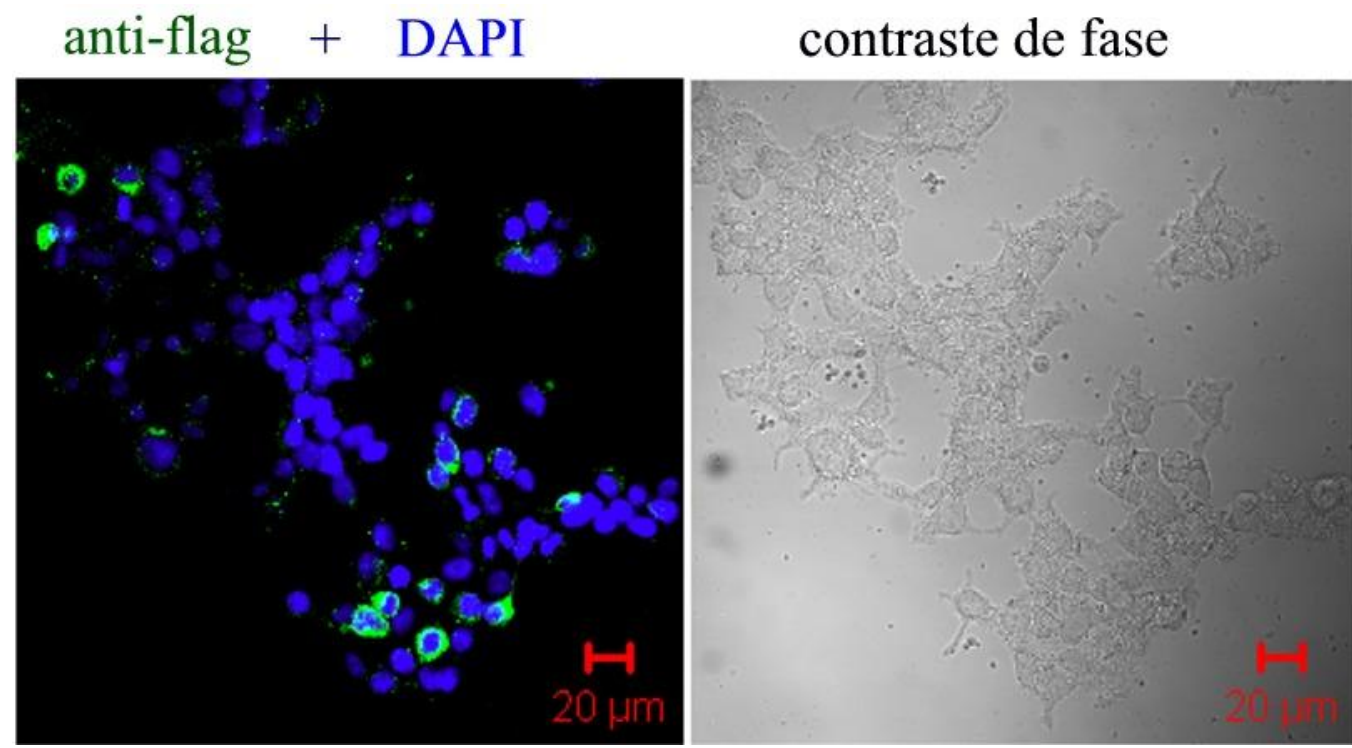

Células foram fixadas, bloqueadas e incubadas com anti-flag (1:500) e anticorpo anti-IgG de camundongo ligado a fluoróforo (em verde, na figura). O DNA foi marcado com DAPI (em azul).

Através de imunoprecipitação de extratos de células HEK293T-PFSR25 com anticorpo anti-flag com posterior western blot, determinamos que a proteína PFSR25 é expressa em células HEK293T em um tamanho de aproximadamente $40 \mathrm{kDa}$, condizente com o tamanho predito (Figura 31). 
Figura 30 - Localização subcelular de pfsr25 em células HEK293T.

anti-flag + aglutinina

$+$

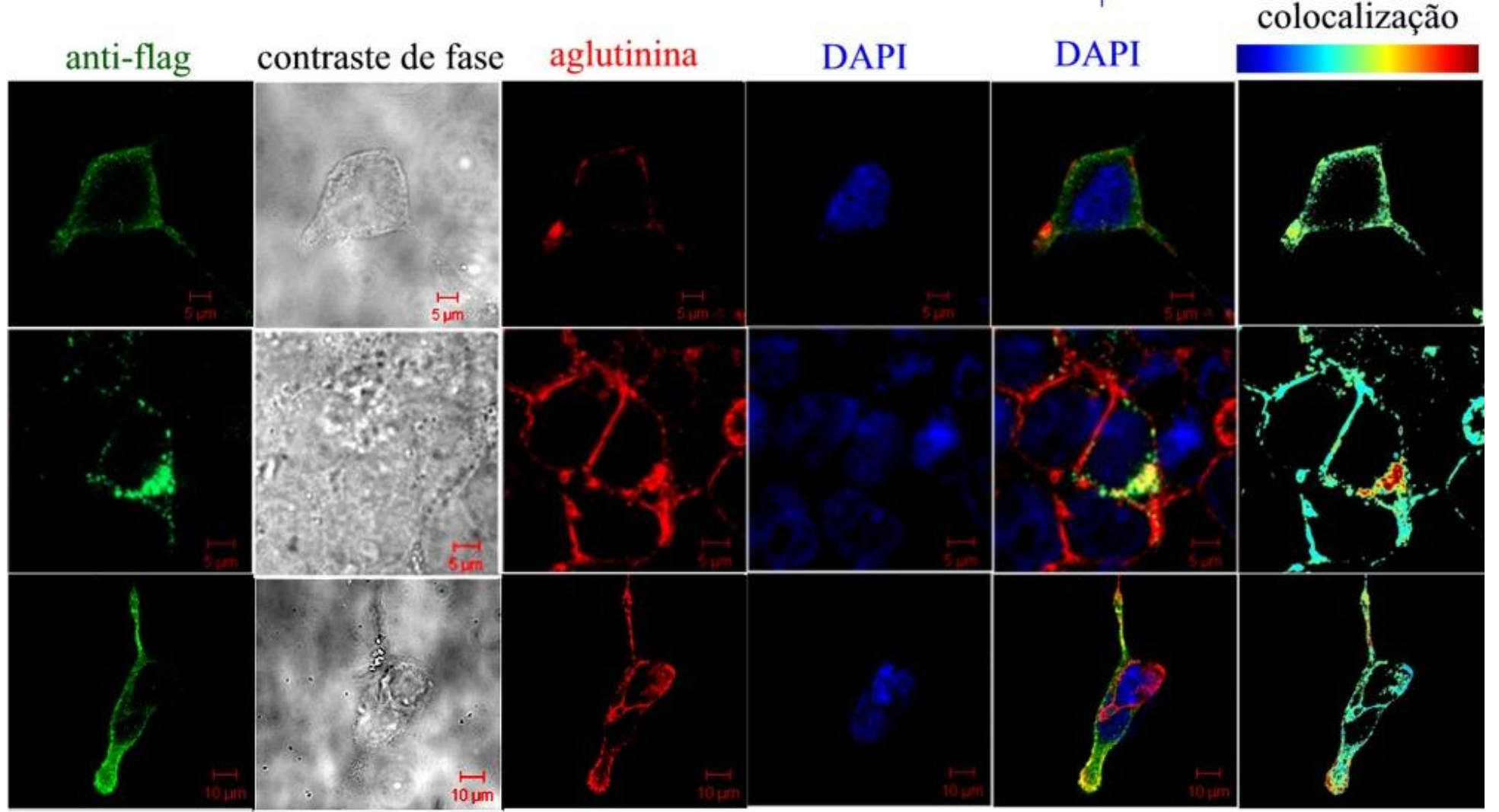

48h após a transfecção, células HEK293T-PFSR25 foram incubadas com o marcador de membrana aglutinina ligado a Alexa 594 (10 $\mu \mathrm{g} / \mathrm{mL})$. As células foram fixadas, bloqueadas e incubadas com anti-flag obtido em camundongo (1:500), anticorpo que reconhece um epítopo adicionado à porção C-terminal de pfsr25. Células foram incubadas com anticorpo anti-IgG de camundongo ligado a Alexa 488 (1:300). O DNA das células foi marcado com DAPI. A colocalização entre o epítopo flag e aglutinina foi obtida através do programa ImageJ, utilizando o plugin colocalization Colormap. Cores próximas ao vermelho indicam maior colocalização. As três células na figura apresentam algum grau de colocalização de pfsr 25 com aglutinina (membrana plasmática). 
Figura 31 - Detecção de pfsr25 em células HEK293T através de imunoprecipitação seguida de western blot.

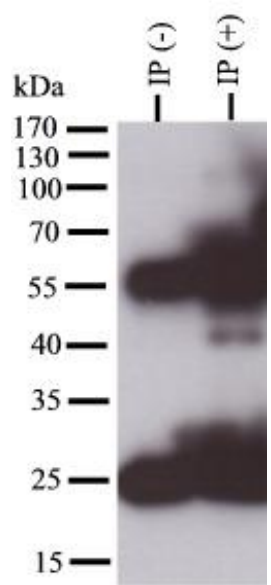

Extratos celulares de HEK293T-PFSR25 foram imunoprecipitados com anticorpo anti-flag. Os imunoprecipitados foram submetidos a SDS-PAGE e transferidos para membrana de PVDF. Após bloqueio da membrana, esta foi submetida a incubação com anticorpo anti-flag e anticorpo secundário anti-IgG de coelho HRP. IP (-): imunoprecipitação executada em células transfectadas com plasmídeo vazio. IP (+): imunoprecipitação executada em células transfectadas com plasmídeo contendo ORF de PFSR25.

\subsubsection{Screening de agonistas para o candidato a receptor serpentino pfsr25: $\mathrm{KCl}$ promove maior aumento de [Ca2+]cit em células HEK293T-PFSR25}

A fim de fazer o screening de agonistas para o receptor putativo pfsr 25 , procedemos de maneira similar ao screening executado com pfsr10. Marcamos células HEK293T-PFSR25 com o indicador fluorescente de $\left[\mathrm{Ca}^{2+}\right]_{\mathrm{cit}}$, Fluo-4 AM e utilizamos um ensaio de highthroughput em fluorímetro de placa. Selecionamos os agonistas a serem testados baseandonos em compostos com efeitos fisiológicos descritos em P. falciparum, assim como compostos que possuíamos no laboratório. Adicionamos os potenciais agonistas de pfsr25, calculando os respectivos aumentos de $\left[\mathrm{Ca}^{2+}\right]_{\text {cit }}$ em células HEK293T-PFSR25 em relação aos aumentos de $\left[\mathrm{Ca}^{2+}\right]_{\mathrm{cit}}$ dos controles negativos, HEK293T-vazio (Tabela 5). Os agonistas da Tabela 5 não foram capazes de promover um aumento diferencial de $\left[\mathrm{Ca}^{2+}\right]_{\text {it }}$ entre células HEK293T-PFSR25 e células HEK293T-vazio. 
Tabela 5 - Screening de agonistas para pfsr25 em células HEK293T.

\begin{tabular}{|c|c|c|}
\hline Composto & Meio extracelular & $\begin{array}{l}\% \text { da resposta de } \\
{\left[\mathrm{Ca}^{2+}\right]_{\text {cit }} \text { em relação à }} \\
\text { resposta do controle; } \\
\text { (número de } \\
\text { gráficos/número de } \\
\text { experimentos) }\end{array}$ \\
\hline $\begin{array}{l}\text { Adenosina } \\
50 \mu \mathrm{M}\end{array}$ & $2 \mathrm{mM} \mathrm{CaCl}_{2}$ & $\begin{array}{l}88 \pm 3 \\
(35 / 5)\end{array}$ \\
\hline $\begin{array}{l}\text { Angiotensina } \\
100 \mathrm{nM}\end{array}$ & $2 \mathrm{mM} \mathrm{CaCl}_{2}$ & $\begin{array}{c}89 \pm 3 \\
(3 / 1)\end{array}$ \\
\hline $\begin{array}{l}\text { ATP } \\
50 \mu \mathrm{M}\end{array}$ & $2 \mathrm{mM} \mathrm{CaCl}{ }_{2}$ & $\begin{array}{l}88 \pm 4 \\
(35 / 5)\end{array}$ \\
\hline $\begin{array}{c}\mathrm{AMPc} \\
1 \mu \mathrm{M}\end{array}$ & $2 \mathrm{mM} \mathrm{CaCl}{ }_{2}$ & $\begin{array}{c}106 \pm 5 \\
(15 / 3)\end{array}$ \\
\hline $\begin{array}{l}\text { Endotelina } \\
100 \mathrm{nM}\end{array}$ & $2 \mathrm{mM} \mathrm{CaCl}{ }_{2}$ & $\begin{array}{c}111 \pm 1 \\
\quad(3 / 1)\end{array}$ \\
\hline $\begin{array}{c}\text { GTP } \\
50 \mu \mathrm{M}\end{array}$ & $2 \mathrm{mM} \mathrm{CaCl}_{2}$ & $\begin{array}{l}97 \pm 5 \\
(27 / 4)\end{array}$ \\
\hline $\begin{array}{l}\text { Somatostatina } \\
100 \mathrm{nM}\end{array}$ & $2 \mathrm{mM} \mathrm{CaCl}{ }_{2}$ & $\begin{array}{c}96 \pm 1 \\
(3 / 1)\end{array}$ \\
\hline $\begin{array}{c}\text { Ácido Xanturênico } \\
100 \mathrm{nM}\end{array}$ & $2 \mathrm{mM} \mathrm{CaCl} 2$ & $\begin{array}{l}81 \pm 8 \\
(10 / 2)\end{array}$ \\
\hline $\begin{array}{c}\mathrm{UTP} \\
50 \mu \mathrm{M}\end{array}$ & $2 \mathrm{mM} \mathrm{CaCl} 2$ & $\begin{array}{l}92 \pm 5 \\
(19 / 3)\end{array}$ \\
\hline $\begin{array}{l}\text { Melatonina } \\
100 \mathrm{nM}\end{array}$ & $2 \mathrm{mM} \mathrm{CaCl} 2$ & $\begin{array}{c}110 \pm 12 \\
(11 / 2)\end{array}$ \\
\hline $\begin{array}{c}\mathrm{N} \text {-acetilserotonina } \\
100 \mathrm{nM}\end{array}$ & $2 \mathrm{mM} \mathrm{CaCl}{ }_{2}$ & $\begin{array}{c}101 \pm 10 \\
\quad(10 / 2)\end{array}$ \\
\hline $\begin{array}{l}\text { Serotonina } \\
100 \mathrm{nM}\end{array}$ & $2 \mathrm{mM} \mathrm{CaCl}_{2}$ & $\begin{array}{c}107 \pm 10 \\
(11 / 2)\end{array}$ \\
\hline $\begin{array}{l}\mathrm{CaCl}_{2} \\
2 \mathrm{mM}\end{array}$ & $0 \mathrm{mM} \mathrm{CaCl}{ }_{2}$ & $\begin{array}{c}104 \pm 5 \\
(12 / 2)\end{array}$ \\
\hline $\begin{array}{c}\mathrm{ADP} \\
50 \mu \mathrm{M}\end{array}$ & $2 \mathrm{mM} \mathrm{CaCl}_{2}$ & $\begin{array}{l}89 \pm 5 \\
(15 / 2) \\
\end{array}$ \\
\hline
\end{tabular}

O aumento de fluorescência do marcador de cálcio Fluo-4 AM após estímulo com os compostos foi calculado através da diferença entre fluorescência máxima e fluorescência mínima após a normalização dos gráficos pela fluorescência basal. $\mathrm{O}$ aumento de cálcio citosólico $\left(\left[\mathrm{Ca}^{2+}\right]_{\mathrm{cit}}\right)$ nas transfecções com PFSR25 foi comparado com os aumentos nos respectivos controles, transfectados com plasmídeo vazio. $\mathrm{O}$ meio extracelular foi suplementado com $\mathrm{CaCl}_{2}$ quando indicado exceto no estímulo com $\mathrm{CaCl}_{2}$ executado em meio extracelular sem adição de cálcio. Os dados foram submetidos a teste estatístico One-Way ANOVA com pós-teste de Dunnett. Não houve diferença estatisticamente significativa em relação ao controle para nenhum dos compostos. Dados estão na forma média \pm erro padrão.

Em busca de um agonista para PFSR25 utilizamos $\mathrm{KCl}$, que aumenta invasão de hepatócitos por esporozoítos (Kumar et al., 2007;Ono et al., 2008). Diminuições na concentração de $\mathrm{KCl}$ extracelular também promove secreção de proteínas importantes para a invasão em merozoítos da fase sanguínea de P. falciparum (Singh et al., 2010). 
Quando estimulamos células HEK293T-PFSR25 com KCl observamos um aumento de $\left[\mathrm{Ca}^{2+}\right]_{\text {cit }}$ superior àquele de células HEK293T-vazio (Figura $32 \mathrm{~A}$ ). O aumento de $\left[\mathrm{Ca}^{2+}\right]_{\mathrm{cit}}$ observado em HEK293T-PFSR25 foi $1.31 \pm 0.03$ maior que o observado em HEK293T-vazio (Figura 32 E). A fim de verificar se essa diferença observada era devida a um efeito osmótico, utilizamos $\mathrm{NaCl}$ para estimular células HEK293T (Figura 32 B, Figura 32 E). Verificamos que apesar de $\mathrm{NaCl}$ provocar um aumento de $\left[\mathrm{Ca}^{2+}\right]_{\text {cit }}$ tanto em HEK293TPFSR25 quanto em HEK293T-vazio (Figura 32 B), não houve diferença estatística entre esses dois aumentos de $\left[\mathrm{Ca}^{2+}\right]_{\text {cit }}$ (Figura 32 E). Um agonista não relacionado, acetilcolina, utilizado na mesma série de experimentos, também não foi capaz de promover um aumento de $\left[\mathrm{Ca}^{2+}\right]_{\text {cit }}$ diferencial entre células HEK293T-PFSR25 e células HEK293T-vazio (Figura 32 E).

A fim de explorar o mecanismo através do qual $\mathrm{KCl}$ promove aumento de $\left[\mathrm{Ca}^{2+}\right]_{\mathrm{cit}} \mathrm{em}$ células HEK293T-PFSR25, utilizamos o quelante de cálcio extracelular EGTA. Sob essas condições, o aumento de $\left[\mathrm{Ca}^{2+}\right]_{\text {cit }}$ promovido por $\mathrm{KCl}$ em células HEK293T-PFSR25 foi praticamente abolido (Figura 32 C) e também não foi observada diferença estatística em relação a HEK293T-vazio (Figura 32 E). Exploramos, também, o efeito de inibidores de canais iônicos na resposta de $\left[\mathrm{Ca}^{2+}\right]_{\text {cit }}$ promovida por $\mathrm{KCl}$ em células HEK293T-PFSR25. Os inibidores de canais de cálcio de membrana $\mathrm{La}^{3+}, \mathrm{Gd}^{3+}$ (Figura 32 D), $\mathrm{Ni}^{2+}$ e nifedipina assim como os inibidores de canal de potássio de membrana $\mathrm{Ba}^{2+}$ e TEA promoveram a inibição do aumento de $\left[\mathrm{Ca}^{2+}\right]_{\text {cit }}$ promovido por $\mathrm{KCl}$ em células HEK293T-PFSR25 (Figura 32 E).

A fim de verificar se o aumento diferencial de $\left[\mathrm{Ca}^{2+}\right]_{\text {cit }}$ promovido por $\mathrm{KCl}$ em células HEK293T-PFSR25 em relação a HEK293T-vazio não seria devido a um maior crescimento de células HEK293T-PFSR25, efetuamos uma contagem de células ao longo de 120 h após a transfecção (Figura 33). Observamos que não houve diferenças entre o número de células HEK293T-vazio e HEK293T-PFSR25 em nenhum dos pontos de tempo (Figura 33). 
Figura 32 - Dinâmica de cálcio em células HEK293T-PFSR25 estimuladas com KCl, $\mathrm{NaCl}$ e acetilcolina.

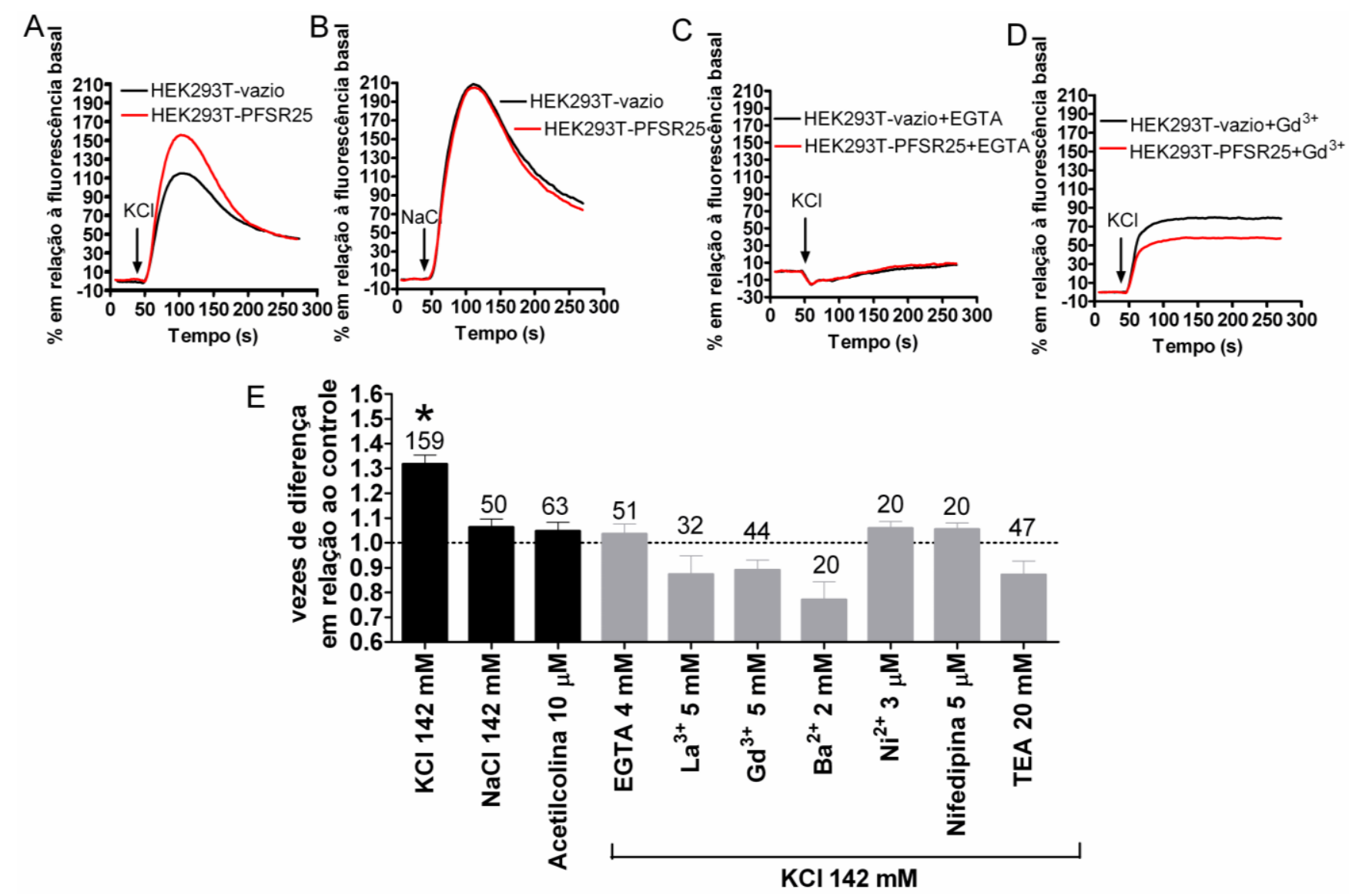

A,B,C,D: Gráficos representativos de dinâmica de cálcio obtidos com estímulos de $\mathrm{KCl} 142 \mathrm{mM}(\mathbf{A}), \mathrm{NaCl} 142 \mathrm{mM}(\mathbf{B}), \mathrm{KCl} 142 \mathrm{mM}$ na presença de $4 \mathrm{mM}$ EGTA extracelular (C) e $\mathrm{KCl} 142 \mathrm{mM}$ na presença de $5 \mathrm{mM} \mathrm{Gd}^{3+}$ extracelular (D). Gráficos apresentados na forma de \% de aumento de fluorescência em relação à fluorescência basal. Transfecções de plasmídeo vazio ou PFSR25 estão indicadas. E: Análise estatística do aumento de cálcio de células transfectadas com PFSR25 em relação ao aumento de cálcio das respectivas células controle (indicado pela linha tracejada). Barras pretas: estímulos com KCl, $\mathrm{NaCl}$ ou acetilcolina. Barras cinza: estímulo com $\mathrm{KCl}$ em células incubadas com os inibidores indicados. * indica diferença significativa em relação ao respectivo controle (One-Way ANOVA com teste de Newman-Keuls). Os resultados são de ao menos três experimentos independentes. Os números acima das barras indicam o número de gráficos de fluorescência analisados. Dados estão plotados na forma de média e erro padrão. 
Figura 33 - Crescimento de células HEK293T-PFSR25 ou HEK293T-vazio.

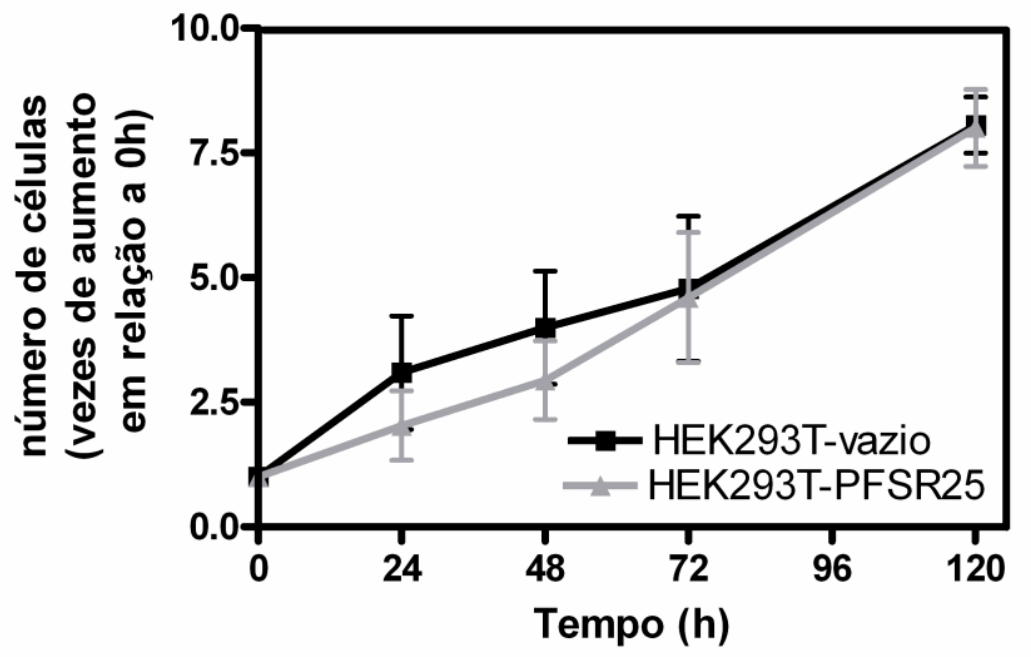

Dados normalizados pelo número de células inicial (transfectadas em $0 \mathrm{~h}$ ). $\mathrm{O}$ número acima das barras indica o número de replicas. Dados estão plotados na forma de média e erro padrão. Resultados são de três experimentos independentes. Dados foram analisados estatisticamente por teste t não pareado, não sendo observadas diferenças estatísticas.

\subsubsection{KCl provoca aumento de $\left[\mathrm{Ca}^{2+}\right]_{c i t}$, dependente de pfsr25, em trofozoítos maduros de $\mathrm{P}$. falciparum e modula a ruptura de eritrócitos infectados por esses estágios}

$\mathrm{O} \mathrm{KCl}$ é importante em diferentes estágios de vida de $P$. falciparum. $\mathrm{KCl}$ aumenta a invasão de hepatócitos por esporozoítos (Kumar et al., 2007; Ono et al., 2008). Além disso, a diminuição da concentração extracelular de $\mathrm{KCl}$ decorrente da ruptura de esquizontes com consequente exposição dos merozoítos à concentração plasmática de $\mathrm{KCl}(5 \mathrm{mM})$ gera secreção de proteínas importantes para a invasão na membrana plasmática do merozoíto (Singh et al., 2010) processo que é dependente de aumento de $\left[\mathrm{Ca}^{2+}\right]_{\text {cit }}$ a partir de estoques internos do parasita (Singh et al., 2010). Como obtivemos evidências de que pfsr25 é um sensor de $\mathrm{KCl}$ (Figura 32) e é expresso principalmente em fases intraeritrocíticas de $P$. falciparum (Figuras 25 e 26), decidimos verificar se $\mathrm{KCl}$ seria capaz de sinalizar em parasitas intraeritrocíticos e se pfsr25 estaria envolvido no processo. Para tanto, nos valemos de experimentos de dinâmica de cálcio utilizando parasitas marcados com o indicador fluorescente Fluo-4 AM. 
Quando estimulamos trofozoítos maduros isolados de hemácias com $\mathrm{KCl}$, verificamos um aumento transiente da concentração de $\left[\mathrm{Ca}^{2+}\right]_{\text {cit }}$ (Figura 34 A). Esse aumento é foi dosedependente e aconteceu em concentrações milimolar de $\mathrm{KCl}$ (Figura $34 \mathrm{~B}$ ). Quando quelamos cálcio extracelular com EGTA, o aumento de $\left[\mathrm{Ca}^{2+}\right]_{\text {cit }}$ após estímulo com $\mathrm{KCl}$ é mantido (Figura 34 C). Porém, quando depletamos estoques internos de cálcio com ácido ciclopiazônico ou thapsigargina (Figura 34 D e 34 E) ou utilizamos um inibidor de fosfolipase C, U73122 (Figura 34 F), verificamos inibição do aumento de $\left[\mathrm{Ca}^{2+}\right]_{\text {cit }}$ provocado por KCl. Um análogo inativo do inibidor de fosfolipase C, U73343, não promove inibição do transiente de $\left[\mathrm{Ca}^{2+}\right]_{\text {cit }}$ promovido por $\mathrm{KCl}$ (Figura $34 \mathbf{G}$ ).

Figura 34 - Aumento de concentração citossólica de cálcio em trofozoítos maduros de $P$. falciparum em resposta a $\mathrm{KCl}$.
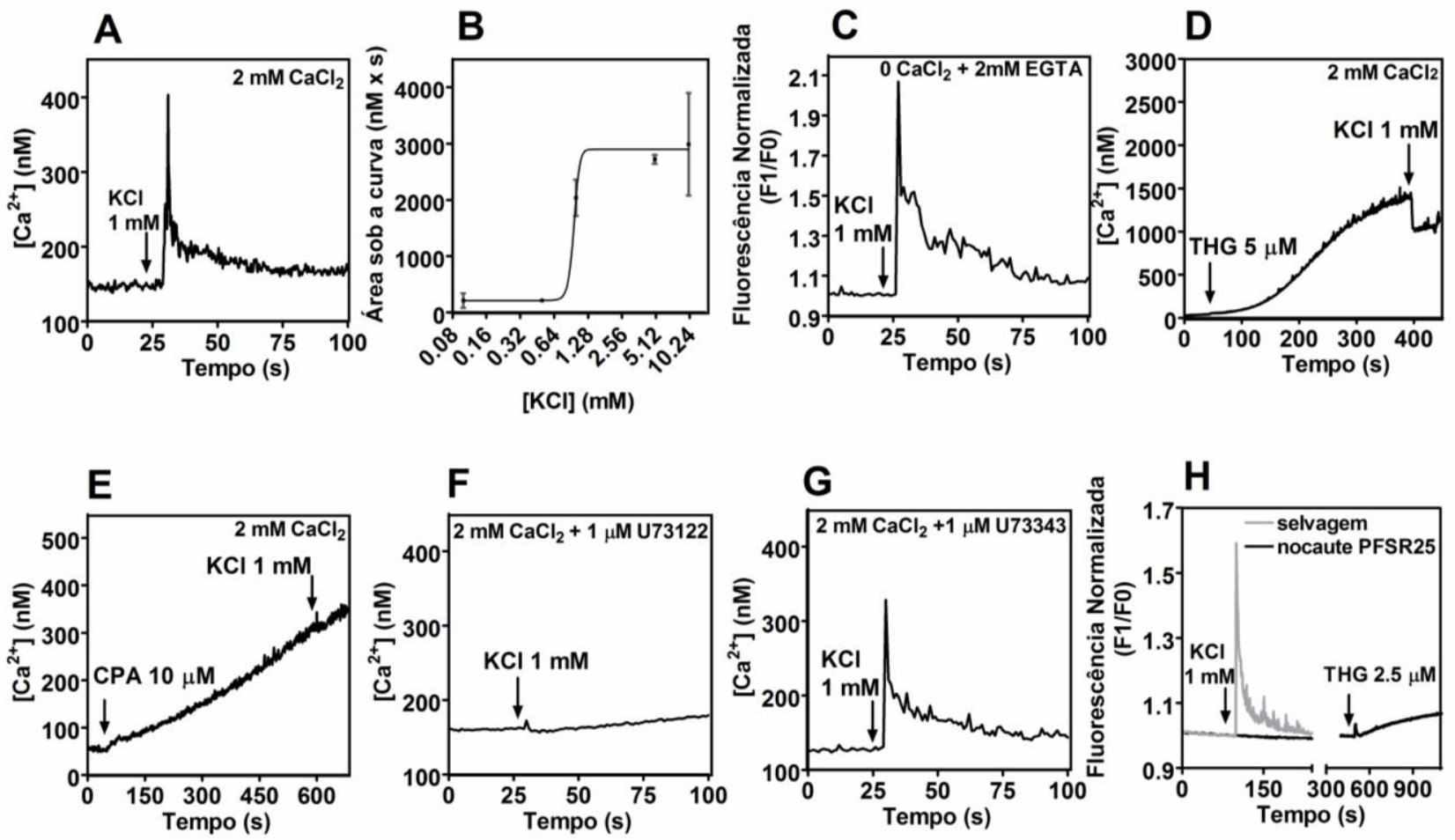

O tampão de ensaio foi suplementado com $\mathrm{CaCl}_{2}$, EGTA, U73122 ou U73343 nas concentrações indicadas. $0 \mathrm{mM} \mathrm{CaCl}$ : tampão sem cálcio nominal. THG: thapsigargina, inibidora de ATPse de cálcio do retículo endoplasmático. CPA: ácido ciclopiazônico, inibidor de ATPase de cálcio do retículo endoplasmático. F1: fluorescência em um ponto de tempo; F0: média da fluorescência da linha de base, antes da adição de $\mathrm{KCl}$.

A fim de verificar se pfsr25 participa no processo de transdução de sinal induzido por $\mathrm{KCl}$ em parasitas intraeritrocíticos, utilizamos um clone de $P$. falciparum nocaute para PFSR25, gerados em nosso laboratório pelo Dr. Julio Garcia. $\mathrm{KCl}$ não foi capaz de promover um aumento de $\left[\mathrm{Ca}^{2+}\right]_{\text {cit }}$ em trofozoítos maduros isolados de parasitas nocaute para pfsr25 
(Figura 34 H) e a adição de thapsigargina após $\mathrm{KCl}$ demonstrou que havia cálcio em estoques internos do parasita passível de ser mobilizado (Figura 34 H) . Em experimentos concomitantes, $\mathrm{KCl}$ foi capaz de aumentar $\left[\mathrm{Ca}^{2+}\right]_{\text {cit }}$ em parasitas selvagens (Figura $34 \mathbf{H}$ ).

Com a finalidade de verificar a função de $\mathrm{KCl}$ no ciclo intraeritrocítico de $P$. falciparum, incubamos eritrócitos infectados com trofozoítos maduros sincronizados com $\mathrm{KCl}$ ou $\mathrm{NaCl}$, na presença de cálcio extracelular ou na presença do quelante de cálcio extracelular EGTA. Após incubação, contamos parasitemia e a proporção de fases em cada tratamento. Verificamos que $\mathrm{KCl}$ promoveu um aumento da proporção de anéis e diminuição da proporção de esquizontes em relação ao controle após incubação com $\mathrm{KCl}$, mesmo na ausência de cálcio externo (Figura $35 \mathrm{~A}$ ). $\mathrm{NaCl}$, por outro lado, não promoveu uma alteração da proporção de fases quando o meio extracelular foi suplementado com cálcio (Figura 35 A). Porém, na presença de quelante extracelular de cálcio EGTA, $\mathrm{NaCl}$ causou um aumento da proporção de fases maduras de $P$. falciparum (Figura 35 A). Isso sugere que a falta de cálcio extracelular retarda o ciclo intraeritrocítico de $P$. falciparum, efeito já observado anteriormente (Gazarini et al., 2003). KCl promoveu uma queda na parasitemia, seja na presença de cálcio extracelular ou na presença de EGTA (Figura 35 B). NaCl, por outro lado, não causou alterações na parasitemia em relação ao controle (Figura 35 B).

Figura 35 - Efeito do $\mathrm{KCl}$ na progressão do ciclo de P. falciparum.
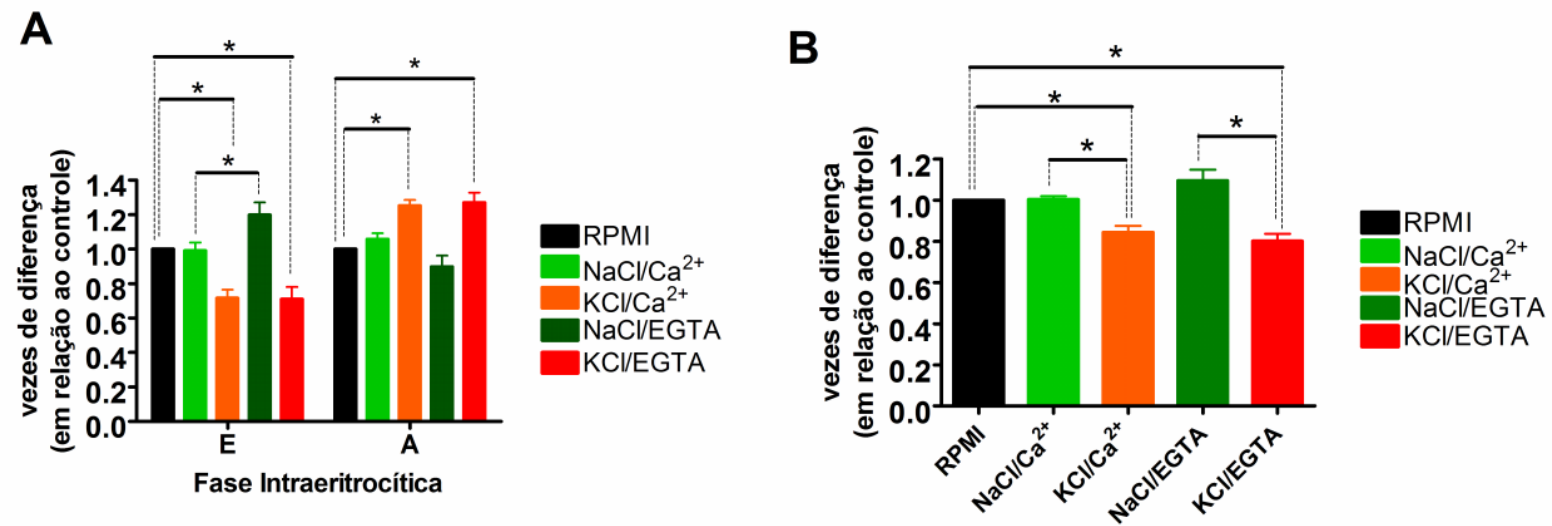

A: distribuição de fases intraeritrocíticas. A- anel, E- esquizonte. B: parasitemia. Culturas sincronizadas na fase de esquizonte jovem foram tratadas por 30 minutos com tampão com alto $\mathrm{KCl}$ ou tampão com alto $\mathrm{NaCl}$ contendo $2 \mathrm{mM}$ de $\mathrm{Ca}^{2+}$ ou $2 \mathrm{mM}$ de EGTA. Após 6 h, parasitemia e fases foram contadas, respectivamente, manualmente em lâminas ou através de citômetro de fluxo. * indica diferença estatística entre as barras indicados por linhas (One-Way ANOVA com teste de Newman Keuls). 


\subsubsection{Proteínas candidatas a interagir com pfsr25 desempenham diversas funções celulares}

A fim de encontrar parceiros moleculares de pfsr25 em P. falciparum utilizamos um experimento de imunoprecipitação similar àquele efetuado para identificar parceiros moleculares de pfsr10. Executamos um western blot do imunoprecipitado (Figura 36 A), no qual identificamos pfsr25, o que validou o experimento de imunoprecipitação. Corremos proteínas do imunoprecipitado em SDS-PAGE e recortamos bandas, tanto do imunoprecipitado quanto do controle negativo, para identificação de peptídeos através de espectrometria de massa (Figura 36 B). Encontramos 65 proteínas exclusivamente presentes no imunoprecipitado (Tabela 6), assim como 15 proteínas três ou mais vezes enriquecidas no imunoprecipitado (Tabela 7).

As proteínas imunoprecipitadas com o anticorpo anti-pfsr25 em $P$. falciparum, exclusivas ou enriquecidas em relação ao controle foram consideradas candidatas para interação com pfsr25.

Após acesso das informações das proteínas no banco de dados do genoma de Plasmodium, PlasmodB, verificamos que algumas candidatas a interagir com pfsr25 não possuem função predita, enquanto outras possuem função predita através de comparações de similaridade. Algumas poucas possuem evidências experimentais de função.

Algumas das proteínas candidatas a interagir com pfsr25 apresentam domínios transmembrânicos e peptídeos sinal de exportação (Tabela 6, Tabela 7).

As proteínas identificadas podem ser divididas em diversas categorias funcionais, entre elas: proteínas relacionadas à tradução, à ubiquitinação, à endocitose, à exportação de proteínas, ao dobramento de proteínas, à proteólise, à invasão e estabelecimento nas células hospedeiras e à replicação do DNA (Tabela 6, Tabela 7). Algumas proteínas em comum com a imunoprecipitação de candidatos a parceiros moleculares de pfsr10 foram encontradas, e sua função encontra-se explorada em maiores detalhes na seção de resultados da imunoprecipitação de pfsr10. 
Figura 36 - Imunoprecipitação de proteínas em P. falciparum com anticorpo anti-pfsr25.

A

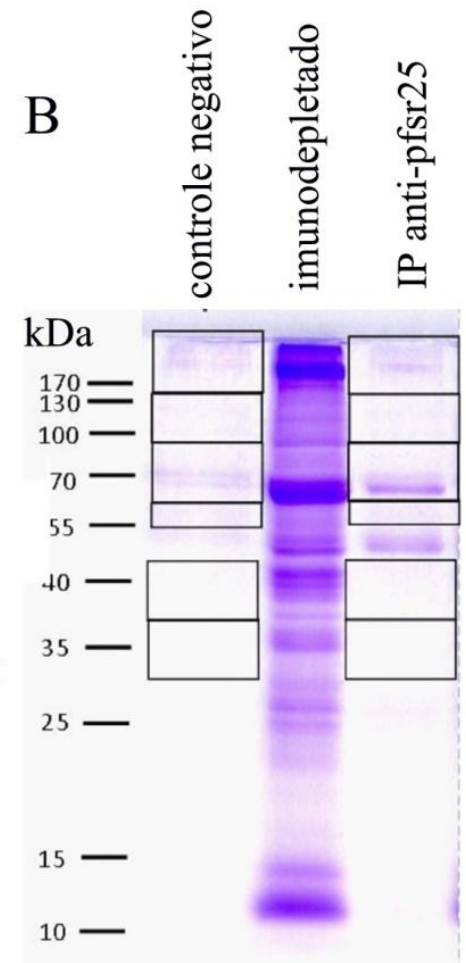

A: Western blot do imunoprecipitado, indicando input (extrato total) e imunoprecipitação (IP) utilizando anticorpo anti-pfsr25. IgGH: cadeia pesada do anticorpo utilizado na imunoprecipitação. B: SDS-PAGE indicando faixas do gel (entre retângulos) enviadas para identificação de proteínas por espectrometria de massa. Lanes: controle negativo (uso apenas de resina na imunoprecipitação, sem anticorpo), imunoprecipitação (IP) utilizando anticorpo anti-pfsr25 e o extrato protéico restante após a imunoprecipitação (imunodepletado).

\subsubsection{Proteínas relacionadas a tradução, via exocítica e via endocítica}

Diversas proteínas que fazem parte da maquinaria da tradução de RNA foram encontradas, incluindo uma subunidade do ribossomo (Tabela 7 proteína 1).

Dentre as proteínas relacionadas com a via exocítica e/ou endocítica destacamos os seguintes fatores: proteína semelhante à dinamina (Tabela 7 proteína 7), PfPAST (Tabela 7 proteína 15), a proteína de fusão sensível a N-etilmaleimida (Tabela 6 proteína 3), Sec31p (Tabela 6 proteína 31) e Sec63p (Tabela 6 proteína 7).

A proteína Sec63p compõe o canal de retículo endoplasmático que se liga a ribossomos no processo de tradução de proteínas com peptídeo sinal. Classicamente, proteínas que possuem um peptídeo sinal nascente se ligam a uma partícula reconhecedora de peptídeo sinal (SRP), que recruta a proteína nascente e o ribossomo para o canal de retículo 
endoplasmático, onde a proteína pode ser inserida na membrana ou passar para o lúmen do retículo. Proteínas assim traduzidas podem ser exportadas para organelas membranares (o próprio retículo endoplasmático, a membrana plasmática, lisossomos e endossomos, revisado em Rapoport, 1992).

Outra proteína identificada, PfPAST, possui similaridade com a proteína humana EHD2, pertencente à classe das dinaminas. EHD2 é uma GTPase envolvida na endocitose independente de clatrina e reciclagem de proteínas a partir do endossomo (Daumke et al., 2007).

\subsubsection{Proteínas relacionadas à ubiquitinação}

Uma proteína relacionada à ubiquitinação, a enzima ativadora de ubiquitina E1 foi encontrada (Tabela 7, proteína 12).

A ubiquitinação de proteínas pode ter diversas funções celulares como reciclagem de receptores de membrana plasmática, regulação de atividade enzimática, permitir interação com outras proteínas e degradação proteica (Acconcia et al., 2009). Com relação ao último exemplo, uma subunidade do proteassomo, responsável pela degradação de proteínas ubiquitinadas foi identificada (Tabela 6 proteína 50).

4.2.6.3 Proteínas relacionadas à saída de eritrócitos, invasão e estabelecimento na célula hospedeira

Proteínas possivelmente relacionadas à invasão do eritrócito e estabelecimento na célula hospedeira também foram identificadas. Estas incluem a M18 aspartil aminopeptidase (Tabela 6 proteína 4), a msp6 (Tabela 6 proteína 48), a EBA175 (Tabela 6 proteína 14), RESA (Tabela 6 proteína 18) e miosina A (Tabela 7 proteína 10).

A proteína MSP-6 (proteína de superfície de merozoíto 6) interage com outras proteínas de superfície relacionadas à invasão, msp1 e msp7 (Kauth et al., 2006). Anticorpos contra msp1 inibem a invasão de eritrócitos (Woehlbier et al., 2010).

\subsubsection{Chaperonas}

Dentro da categoria foram identificadas uma cochaperona (Tabela 7 proteína 14), a proteína ClpB (Tabela 6 proteína 1), e uma proteína hsp90 (Tabela 6 proteína 56). 
As cochaperonas, em conjunto com hsp90, ajudam no dobramento de proteínas através de ligação a domínios hidrofóbicos evitando interações não nativas, na desagregação de complexos proteicos e no encaminhamento de proteínas mal dobradas para degradação via proteassomo (revisado em Taipale et al., 2010).

\subsubsection{Outras proteínas}

Uma ATPase da família cdc48 foi encontrada (Tabela 7 proteína 8). Algumas proteínas relacionadas à replicação e transcrição do DNA foram identificadas: helicases (Tabela 6, Tabela 7) e fatores de transcrição (Tabela 6).

Proteínas relacionadas ao metabolismo energético também foram encontradas (Tabela 6, proteína 46).

Duas fosfatases de serina/treonina também foram identificadas (Tabela 6 proteínas 42 e 62). 
Tabela 6 - Proteínas identificadas exclusivamente na imunoprecipitação com anticorpo anti-pfsr25, em trofozoítos e esquizontes.

(continua)

\begin{tabular}{|c|c|c|c|c|c|c|c|}
\hline $\begin{array}{l}\text { Número da } \\
\text { proteína }\end{array}$ & $\begin{array}{c}\text { Nome de } \\
\text { Proteína de } P \text {. } \\
\text { falciparum } \\
\text { Identificada }\end{array}$ & $\begin{array}{l}\text { Número de } \\
\text { Acesso } \\
\text { PlasmodB }\end{array}$ & $\begin{array}{c}\text { Peso } \\
\text { Molecular } \\
\text { da } \\
\text { Proteína } \\
\text { (kDa) } \\
\end{array}$ & $\begin{array}{l}\text { Peptídeo } \\
\text { Sinal } \\
\text { predito? }\end{array}$ & $\begin{array}{c}\text { Domínios } \\
\text { Transmembrana } \\
\text { preditos? } \\
\text { (número) }\end{array}$ & $\begin{array}{l}\text { Possível } \\
\text { Função }\end{array}$ & $\begin{array}{c}\text { Peptídeos } \\
\text { Encontrados } \\
\text { na } \\
\text { Espectrometria } \\
\text { de Massa } \\
\end{array}$ \\
\hline 1 & Proteína ClpB & PF08_0063 & 122 & Sim & $\operatorname{Sim}(1)$ & $\begin{array}{c}\text { Chaperona, } \\
\text { desfaz } \\
\text { agregados }\end{array}$ & 8 \\
\hline 2 & $\begin{array}{l}\text { Subunidade de } \\
\text { complexo de } \\
\text { manutenção de } \\
\text { minicromossomo }\end{array}$ & PF13_0291 & 105 & Não & Não & $\begin{array}{c}\text { Replicação de } \\
\text { DNA }\end{array}$ & 5 \\
\hline 3 & $\begin{array}{c}\text { Proteína de fusão } \\
\text { sensível a N- } \\
\text { etilmaleimida }\end{array}$ & PFC0140c & 89 & Não & Não & $\begin{array}{l}\text { Fusão de } \\
\text { vesículas }\end{array}$ & 3 \\
\hline 4 & $\begin{array}{c}\text { M18 aspartil } \\
\text { aminopeptidase }\end{array}$ & PFI1570c & 65 & Não & Não & $\begin{array}{c}\text { Evasão do } \\
\text { eritrócito entre } \\
\text { outras funções }\end{array}$ & 3 \\
\hline 5 & $\begin{array}{l}\text { Proteína 6- } \\
\text { cisteína }\end{array}$ & PFE0395c & 40 & Sim & $\operatorname{Sim}(1)$ & $\begin{array}{l}\text { Desconhecida. } \\
\text { Possui âncora } \\
\text { de GPI }\end{array}$ & 3 \\
\hline 6 & $\begin{array}{c}\text { Fator de } \\
\text { iniciação de } \\
\text { transcrição } \\
\text { subunidade alfa }\end{array}$ & PF07_0117 & 37 & Não & Não & $\begin{array}{c}\text { Transcrição de } \\
\text { DNA }\end{array}$ & 3 \\
\hline 7 & Sec63p & PF13_0102 & 75 & Não & $\operatorname{Sim}(3)$ & Exportação & 3 \\
\hline
\end{tabular}


Tabela 6 - Proteínas identificadas exclusivamente na imunoprecipitação com anticorpo anti-pfsr25, em trofozoitos e esquizontes.

(continuação)

\begin{tabular}{|c|c|c|c|c|c|c|c|}
\hline $\begin{array}{l}\text { Número da } \\
\text { proteína }\end{array}$ & $\begin{array}{c}\text { Nome de } \\
\text { Proteína de } P \text {. } \\
\text { falciparum } \\
\text { Identificada }\end{array}$ & $\begin{array}{l}\text { Número de } \\
\text { Acesso } \\
\text { PlasmodB }\end{array}$ & $\begin{array}{c}\text { Peso } \\
\text { Molecular } \\
\text { da } \\
\text { Proteína } \\
\text { (kDa) } \\
\end{array}$ & $\begin{array}{l}\text { Peptídeo } \\
\text { Sinal } \\
\text { predito? }\end{array}$ & $\begin{array}{c}\text { Domínios } \\
\text { Transmembrana } \\
\text { preditos? } \\
\text { (número) }\end{array}$ & $\begin{array}{l}\text { Possível } \\
\text { Função }\end{array}$ & $\begin{array}{c}\text { Peptídeos } \\
\text { Encontrados } \\
\text { na } \\
\text { Espectrometria } \\
\text { de Massa } \\
\end{array}$ \\
\hline 8 & $\begin{array}{l}\text { Antígeno de } \\
\text { membrana } \\
\text { associado à } \\
\text { roptria }\end{array}$ & MAL7P1.208 & 103 & $\operatorname{Sim}$ & Não & Desconhecido & 2 \\
\hline 9 & $\begin{array}{l}\text { Leucil RNA } \\
\text { sintase }\end{array}$ & PFF1095w & 170 & Não & Não & $\begin{array}{c}\text { Tradução de } \\
\text { RNA }\end{array}$ & 2 \\
\hline 10 & $\begin{array}{c}\text { Fator de } \\
\text { replicação c } \\
\text { subunidade } 1\end{array}$ & PFB0895c & 104 & Não & Não & $\begin{array}{c}\text { Replicação do } \\
\text { DNA }\end{array}$ & 2 \\
\hline 11 & $\begin{array}{c}\text { Proteína putativa } \\
\text { de ligação ao } \\
\text { RNA }\end{array}$ & PFI0820c & 45 & Não & Não & Desconhecida & 2 \\
\hline 12 & $\begin{array}{c}\text { Hidrolase } \\
\text { carboxil terminal } \\
\text { de ubiquitina }\end{array}$ & PFE1355c & 70 & Não & Não & $\begin{array}{c}\text { Diversos } \\
\text { Processos }\end{array}$ & 2 \\
\hline 13 & $\begin{array}{c}\text { Sintetase de } \\
\text { dihidropteroato }\end{array}$ & PF08_0095 & 83 & Não & Não & $\begin{array}{l}\text { Síntese de } \\
\text { vitamina }\end{array}$ & 2 \\
\hline 14 & EBA 175 & MAL7P1.176 & 174 & $\operatorname{Sim}$ & Não & $\begin{array}{c}\text { Invasão de } \\
\text { eritrócito }\end{array}$ & 2 \\
\hline 15 & $\begin{array}{c}\text { Seril tRNA } \\
\text { sintetase putativa }\end{array}$ & PF07_0073 & 62 & Não & Não & $\begin{array}{c}\text { Tradução de } \\
\text { RNA }\end{array}$ & 2 \\
\hline 16 & Ala tRNA ligase & PF13_0354 & 165 & Sim & Não & Tradução RNA & 2 \\
\hline
\end{tabular}


Tabela 6 - Proteínas identificadas exclusivamente na imunoprecipitação com anticorpo anti-pfsr25, em trofozoitos e esquizontes.

\begin{tabular}{|c|c|c|c|c|c|c|c|}
\hline $\begin{array}{l}\text { Número da } \\
\text { proteína }\end{array}$ & $\begin{array}{c}\text { Nome de } \\
\text { Proteína de } P \text {. } \\
\text { falciparum } \\
\text { Identificada }\end{array}$ & $\begin{array}{c}\text { Número de } \\
\text { Acesso } \\
\text { PlasmodB }\end{array}$ & $\begin{array}{c}\text { Peso } \\
\text { Molecular } \\
\text { da } \\
\text { Proteína } \\
\text { (kDa) }\end{array}$ & $\begin{array}{l}\text { Peptídeo } \\
\text { Sinal } \\
\text { predito? }\end{array}$ & $\begin{array}{c}\text { Domínios } \\
\text { Transmembrana } \\
\text { preditos? } \\
\text { (número) }\end{array}$ & $\begin{array}{l}\text { Possível } \\
\text { Função }\end{array}$ & $\begin{array}{c}\text { Peptídeos } \\
\text { Encontrados } \\
\text { na } \\
\text { Espectrometria } \\
\text { de Massa }\end{array}$ \\
\hline 17 & $\begin{array}{c}\text { Proteína Kelch, } \\
\text { putativa }\end{array}$ & PF13_0238 & 83 & Não & Não & $\begin{array}{c}\text { Homologia com } \\
\text { proteína } \\
\text { adaptadora de } \\
\text { E3 ubiquitina } \\
\text { ligase, } \\
\text { Ubiquitinação }\end{array}$ & 2 \\
\hline 18 & RESA & PF11_0509 & 126 & Sim & Não & $\begin{array}{c}\text { Estabelecimento } \\
\text { na célula } \\
\text { hospedeira }\end{array}$ & 2 \\
\hline 19 & $\begin{array}{c}\text { Fenilalanil tRNA } \\
\text { sintetase cadeia } \\
\text { beta, putativa }\end{array}$ & PF11_0051 & 72 & Não & Não & $\begin{array}{l}\text { Tradução de } \\
\text { RNA }\end{array}$ & 2 \\
\hline 20 & $\begin{array}{c}\text { Proteína rica em } \\
\text { glutamato }\end{array}$ & PF10_0344 & 141 & Sim & Não & Desconhecida & 2 \\
\hline 21 & $\begin{array}{l}\text { Proteína de } \\
\text { reparo de DNA } \\
\text { RAD32 }\end{array}$ & PF10_0114 & 44 & Não & Não & Reparo de DNA & 2 \\
\hline 22 & $\begin{array}{l}\text { Sortilina, } \\
\text { putativa }\end{array}$ & PF14_0493 & 102 & Não & $\operatorname{Sim}(2)$ & $\begin{array}{c}\text { Exportação de } \\
\text { proteínas para } \\
\text { lisossomo }\end{array}$ & 2 \\
\hline 23 & $\begin{array}{c}\text { Proteína } \\
\text { conservada }\end{array}$ & PF14_0191 & 59 & Não & Não & Desconhecida & 2 \\
\hline
\end{tabular}


Tabela 6 - Proteínas identificadas exclusivamente na imunoprecipitação com anticorpo anti-pfsr25, em trofozoitos e esquizontes.

\begin{tabular}{|c|c|c|c|c|c|c|c|}
\hline $\begin{array}{l}\text { Número da } \\
\text { proteína }\end{array}$ & $\begin{array}{c}\text { Nome de } \\
\text { Proteína de } P \text {. } \\
\text { falciparum } \\
\text { Identificada }\end{array}$ & $\begin{array}{l}\text { Número de } \\
\text { Acesso } \\
\text { PlasmodB }\end{array}$ & $\begin{array}{c}\text { Peso } \\
\text { Molecular } \\
\text { da } \\
\text { Proteína } \\
\text { (kDa) } \\
\end{array}$ & $\begin{array}{l}\text { Peptídeo } \\
\text { Sinal } \\
\text { predito? }\end{array}$ & $\begin{array}{c}\text { Domínios } \\
\text { Transmembrana } \\
\text { preditos? } \\
\text { (número) }\end{array}$ & $\begin{array}{l}\text { Possível } \\
\text { Função }\end{array}$ & $\begin{array}{c}\text { Peptídeos } \\
\text { Encontrados } \\
\text { na } \\
\text { Espectrometria } \\
\text { de Massa } \\
\end{array}$ \\
\hline 24 & $\begin{array}{c}\text { Proteína } \\
\text { conservada }\end{array}$ & PF14_0186 & 80 & Sim & Não & Desconhecida & 2 \\
\hline 26 & $\begin{array}{l}\text { Regulador de } \\
\text { condensação } \\
\text { cromossômica }\end{array}$ & MAL7P1.38 & 79 & Não & Não & Desconhecida & 1 \\
\hline 27 & $\begin{array}{c}\text { Proteína putativa } \\
\text { de roptria } 5\end{array}$ & MAL8P1.73 & 133 & Não & Não & Desconhecida & 1 \\
\hline 28 & $\begin{array}{c}\text { Fator de } \\
\text { iniciação de } \\
\text { transcrição } 4 \gamma\end{array}$ & MAL13P1.63 & 146 & Não & Não & $\begin{array}{c}\text { Transcrição de } \\
\text { RNA }\end{array}$ & 1 \\
\hline 29 & $\begin{array}{c}\text { Proteína } \\
\text { conservada }\end{array}$ & PFF0835w & 53 & Não & Não & Desconhecida & 1 \\
\hline 30 & Transportina & PFF1345w & 132 & Não & Não & $\begin{array}{l}\text { Exportação para } \\
\text { o núcelo }\end{array}$ & 1 \\
\hline 31 & Proteína sec31 & PFB0640c & 166 & Não & Não & $\begin{array}{l}\text { Cobertura de } \\
\text { Vesículas }\end{array}$ & 1 \\
\hline 32 & $\begin{array}{c}\text { Ubiquitina } \\
\text { carboxil terminal } \\
\text { hidrolase }\end{array}$ & PFD0680c & 98 & Não & Não & Deubiquitinação & 1 \\
\hline 33 & $\begin{array}{c}\text { Simporter de } \\
\text { lipídeo/sterol: } \mathrm{H}^{+}\end{array}$ & PFA0375c & 170 & Não & $\operatorname{Sim}(12)$ & $\begin{array}{l}\text { Transporte de } \\
\text { lipídeos }\end{array}$ & 1 \\
\hline
\end{tabular}


Tabela 6 - Proteínas identificadas exclusivamente na imunoprecipitação com anticorpo anti-pfsr25, em trofozoitos e esquizontes.

\begin{tabular}{|c|c|c|c|c|c|c|c|}
\hline $\begin{array}{l}\text { Número da } \\
\text { proteína }\end{array}$ & $\begin{array}{c}\text { Nome de } \\
\text { Proteína de } P \text {. } \\
\text { falciparum } \\
\text { Identificada }\end{array}$ & $\begin{array}{l}\text { Número de } \\
\text { Acesso } \\
\text { PlasmodB }\end{array}$ & $\begin{array}{c}\text { Peso } \\
\text { Molecular } \\
\text { da } \\
\text { Proteína } \\
\text { (kDa) } \\
\end{array}$ & $\begin{array}{l}\text { Peptídeo } \\
\text { Sinal } \\
\text { predito? }\end{array}$ & $\begin{array}{c}\text { Domínios } \\
\text { Transmembrana } \\
\text { preditos? } \\
\text { (número) }\end{array}$ & $\begin{array}{l}\text { Possível } \\
\text { Função }\end{array}$ & $\begin{array}{c}\text { Peptídeos } \\
\text { Encontrados } \\
\text { na } \\
\text { Espectrometria } \\
\text { de Massa } \\
\end{array}$ \\
\hline 34 & $\begin{array}{c}\text { Decarboxilase de } \\
\text { fosfatidilserina }\end{array}$ & PFI1370c & 41 & Não & Não & & 1 \\
\hline 35 & $\begin{array}{c}\text { Proteína } \\
\text { exportada }\end{array}$ & PFE1600w & 60 & Não & Não & Desconhecida & 1 \\
\hline 36 & $\begin{array}{c}\text { Proteína de } \\
\text { manutenção de } \\
\text { minicromossomo } \\
3\end{array}$ & PFE1345c & 109 & Não & Não & $\begin{array}{c}\text { Replicação do } \\
\text { DNA }\end{array}$ & 1 \\
\hline 37 & $\begin{array}{c}\text { Fator de } \\
\text { iniciação de } \\
\text { transcrição } \\
\text { eucariótico } 5\end{array}$ & PFL0335c & 64 & Não & Não & $\begin{array}{c}\text { Transcrição de } \\
\text { RNAm }\end{array}$ & 1 \\
\hline 38 & $\begin{array}{l}\text { Proteína com } \\
\text { domínio CS }\end{array}$ & MAL8P1.96 & 37 & Não & Não & Desconhecida & 1 \\
\hline 39 & $\begin{array}{l}\text { Antígeno de } \\
\text { micronema }\end{array}$ & PF08_0008 & 85 & Sim & $\operatorname{Sim}(2)$ & $\begin{array}{c}\text { Desconhecida, } \\
\text { possui âncora } \\
\text { de GPI }\end{array}$ & 1 \\
\hline 40 & $\begin{array}{l}\text { Proteína similar } \\
\text { à ferr. redutase }\end{array}$ & PF07_0085 & 72 & Não & Não & $\begin{array}{l}\text { Matabolismo de } \\
\text { ácidos graxos }\end{array}$ & 1 \\
\hline
\end{tabular}


Tabela 6 - Proteínas identificadas exclusivamente na imunoprecipitação com anticorpo anti-pfsr25, em trofozoitos e esquizontes.

\begin{tabular}{|c|c|c|c|c|c|c|c|}
\hline $\begin{array}{l}\text { Número da } \\
\text { proteína }\end{array}$ & $\begin{array}{c}\text { Nome de } \\
\text { Proteína de } P \text {. } \\
\text { falciparum } \\
\text { Identificada }\end{array}$ & $\begin{array}{l}\text { Número de } \\
\text { Acesso } \\
\text { PlasmodB }\end{array}$ & $\begin{array}{c}\text { Peso } \\
\text { Molecular } \\
\text { da } \\
\text { Proteína } \\
\text { (kDa) } \\
\end{array}$ & $\begin{array}{l}\text { Peptídeo } \\
\text { Sinal } \\
\text { predito? }\end{array}$ & $\begin{array}{c}\text { Domínios } \\
\text { Transmembrana } \\
\text { preditos? } \\
\text { (número) }\end{array}$ & $\begin{array}{l}\text { Possível } \\
\text { Função }\end{array}$ & $\begin{array}{c}\text { Peptídeos } \\
\text { Encontrados } \\
\text { na } \\
\text { Espectrometria } \\
\text { de Massa } \\
\end{array}$ \\
\hline 41 & $\begin{array}{c}\text { Fator } \\
\text { licenciamento } \\
\text { replicação } \\
(\mathrm{mcm} 7)\end{array}$ & PF07_0023 & 94 & Não & Não & $\begin{array}{c}\text { Replicação do } \\
\text { DNA }\end{array}$ & 1 \\
\hline 42 & $\begin{array}{l}\text { Serina/treonina } \\
\text { fosfatase }\end{array}$ & MAL13P1.274 & 76 & Não & Não & Desconhecida & 1 \\
\hline 43 & $\begin{array}{c}\text { Transportador de } \\
\text { nucleosídeo }\end{array}$ & PF13_0252 & 47 & Não & $\operatorname{Sim}(9)$ & $\begin{array}{l}\text { Transporte de } \\
\text { nucleosídeos }\end{array}$ & 1 \\
\hline 44 & Fator de splicing & MAL13P1.120 & 100 & Não & Não & $\begin{array}{c}\text { Processamento } \\
\text { de RNAm }\end{array}$ & 1 \\
\hline 45 & $\begin{array}{c}\text { Carbamil fosfato } \\
\text { sintetase }\end{array}$ & PF13_0044 & 273 & Não & Não & $\begin{array}{c}\text { Síntese de } \\
\text { pirimidina e } \\
\text { arginina, ciclo } \\
\text { da uréia }\end{array}$ & 1 \\
\hline 46 & $\begin{array}{l}\text { Succinil CoA } \\
\text { sintetase } \alpha\end{array}$ & PF11_0097 & 35 & Não & Não & $\begin{array}{l}\text { Metabolismo } \\
\text { energético }\end{array}$ & 1 \\
\hline 47 & $\begin{array}{l}\text { Proteína de } \\
\text { remodelamento } \\
\text { da cromatina }\end{array}$ & PF11_0053 & 167 & Não & Não & Desconhecida & 1 \\
\hline 48 & MSP6 & PF10_0346 & 42 & Não & Não & $\begin{array}{l}\text { Invasão do } \\
\text { eritrócito }\end{array}$ & 1 \\
\hline 49 & $\begin{array}{c}\text { Proteína } \\
\text { conservada }\end{array}$ & PF10_0126 & 43 & Não & Não & Desconhecida & 1 \\
\hline
\end{tabular}


Tabela 6 - Proteínas identificadas exclusivamente na imunoprecipitação com anticorpo anti-pfsr25, em trofozoitos e esquizontes.

\begin{tabular}{|c|c|c|c|c|c|c|c|}
\hline $\begin{array}{c}\text { Número da } \\
\text { proteína }\end{array}$ & $\begin{array}{c}\text { Nome de } \\
\text { Proteína de } P \text {. } \\
\text { falciparum } \\
\text { Identificada }\end{array}$ & $\begin{array}{l}\text { Número de } \\
\text { Acesso } \\
\text { PlasmodB }\end{array}$ & $\begin{array}{c}\text { Peso } \\
\text { Molecular } \\
\text { da } \\
\text { Proteína } \\
\text { (kDa) }\end{array}$ & $\begin{array}{l}\text { Peptídeo } \\
\text { Sinal } \\
\text { predito? }\end{array}$ & $\begin{array}{c}\text { Domínios } \\
\text { Transmembrana } \\
\text { preditos? } \\
\text { (número) }\end{array}$ & $\begin{array}{l}\text { Possível } \\
\text { Função }\end{array}$ & $\begin{array}{c}\text { Peptídeos } \\
\text { Encontrados } \\
\text { na } \\
\text { Espectrometria } \\
\text { de Massa }\end{array}$ \\
\hline 50 & $\begin{array}{c}\text { Subunidade beta } \\
\text { de Proteassomo } \\
20 \mathrm{~S}\end{array}$ & PF10_0111 & 30 & Não & Não & Proteólise & 1 \\
\hline 51 & $\begin{array}{c}\text { Fator de } \\
\text { transcrição } \\
\text { putativo com } \\
\text { domínios AP2 }\end{array}$ & PF10_0075 & 182 & Não & Não & $\begin{array}{c}\text { Transcrição de } \\
\text { RNA }\end{array}$ & 1 \\
\hline 52 & Proteína PF70 & PF10_0025 & 69 & Não & $\operatorname{Sim}(1)$ & Desconhecida & 1 \\
\hline 53 & $\begin{array}{c}\text { Proteína } \\
\text { conservada }\end{array}$ & PF14_0714 & 46 & Não & $\operatorname{Sim}(6)$ & Desconhecida & 1 \\
\hline 55 & $\begin{array}{c}\text { Helicase DEAD } \\
\text { box putativa }\end{array}$ & PF14_0563 & 84 & Não & Não & $\begin{array}{c}\text { Replicação do } \\
\text { DNA }\end{array}$ & 1 \\
\hline 56 & $\begin{array}{l}\text { Heat shock } \\
\text { protein } 90\end{array}$ & PF14_0417 & 107 & Sim & Não & $\begin{array}{l}\text { Dobramento de } \\
\text { proteínas }\end{array}$ & 1 \\
\hline 57 & $\begin{array}{c}\text { Proteína putativa } \\
\text { de ligação a } \\
\text { tRNA }\end{array}$ & PF14_0401 & 46 & Não & Não & Desconhecida & 1 \\
\hline 58 & Proteína putativa & PF14_0390 & 26 & Não & Não & Desconhecida & 1 \\
\hline 59 & $\begin{array}{c}\text { Succinil CoA } \\
\text { ligase, putativa }\end{array}$ & PF14_0357 & 111 & Não & Não & $\begin{array}{l}\text { Metabolismo } \\
\text { energético }\end{array}$ & 1 \\
\hline
\end{tabular}


Tabela 6 - Proteínas identificadas exclusivamente na imunoprecipitação com anticorpo anti-pfsr25, em trofozoitos e esquizontes.

\begin{tabular}{|c|c|c|c|c|c|c|c|}
\hline $\begin{array}{c}\text { Número da } \\
\text { proteína }\end{array}$ & $\begin{array}{c}\text { Nome de } \\
\text { Proteína de } P \text {. } \\
\text { falciparum } \\
\text { Identificada }\end{array}$ & $\begin{array}{c}\text { Número de } \\
\text { Acesso } \\
\text { PlasmodB }\end{array}$ & $\begin{array}{c}\text { Peso } \\
\text { Molecular } \\
\text { da } \\
\text { Proteína } \\
\text { (kDa) } \\
\end{array}$ & $\begin{array}{c}\text { Peptídeo } \\
\text { Sinal } \\
\text { predito? }\end{array}$ & $\begin{array}{c}\text { Domínios } \\
\text { Transmembrana } \\
\text { preditos? } \\
\text { (número) }\end{array}$ & $\begin{array}{l}\text { Possível } \\
\text { Função }\end{array}$ & $\begin{array}{c}\text { Peptídeos } \\
\text { Encontrados } \\
\text { na } \\
\text { Espectrometria } \\
\text { de Massa } \\
\end{array}$ \\
\hline 60 & $\begin{array}{c}\text { DNA } \\
\text { topoisomerase } 2\end{array}$ & PF14_0316 & 169 & Não & Não & $\begin{array}{c}\text { Replicação do } \\
\text { DNA }\end{array}$ & 1 \\
\hline 61 & $\begin{array}{l}\text { Pseudouridina } \\
\text { sintase, putativa }\end{array}$ & PF14_0174 & 59 & Não & Não & $\begin{array}{c}\text { Tradução de } \\
\text { RNA }\end{array}$ & 1 \\
\hline 62 & $\begin{array}{l}\text { Serina/Treonina } \\
\text { fosfatase }\end{array}$ & PF14_0142 & 34 & Não & Não & Desconhecida & 1 \\
\hline 63 & $\begin{array}{l}\text { Proteína de } \\
\text { ligação a } \\
\text { reticulocito }\end{array}$ & PF13_0198 & 370 & Não & Não & Desconhecida & 1 \\
\hline 64 & $\begin{array}{l}\text { Proteína } \\
\text { homóloga a } \\
\text { SEY1 }\end{array}$ & PF14_0159 & 110 & Não & $\operatorname{Sim}(2)$ & $\begin{array}{l}\text { SEY1: fusão e } \\
\text { fissão de } \\
\text { túbulos retículo } \\
\text { endoplasmático }\end{array}$ & 1 \\
\hline 65 & $\begin{array}{l}\text { Tioredoxina } \\
\text { Redutase } 2\end{array}$ & PFI1170c & 68 & Não & Não & $\begin{array}{c}\text { Redução de } \\
\text { pontes } \\
\text { dissulfeto }\end{array}$ & 1 \\
\hline
\end{tabular}


Tabela 7 - Proteínas enriquecidas mais que 3 vezes em relação ao controle na imunoprecipitação utilizando o anticorpo anti-pfsr25, em trofozoítos e esquizontes.

(continua)

\begin{tabular}{|c|c|c|c|c|c|c|c|}
\hline $\begin{array}{l}\text { Número } \\
\text { da } \\
\text { proteína }\end{array}$ & $\begin{array}{c}\text { Nome de } \\
\text { Proteína de } \\
P \text {.falciparum } \\
\text { Identificada }\end{array}$ & $\begin{array}{c}\text { Número de } \\
\text { Acesso } \\
\text { PlasmodB }\end{array}$ & $\begin{array}{c}\text { Peso } \\
\text { Molecular } \\
\text { da } \\
\text { Proteína } \\
\text { (kDa) }\end{array}$ & $\begin{array}{l}\text { Peptídeo } \\
\text { Sinal } \\
\text { predito? }\end{array}$ & $\begin{array}{c}\text { Domínios } \\
\text { Transmembrana } \\
\text { preditos? } \\
\text { (número) }\end{array}$ & $\begin{array}{l}\text { Possível } \\
\text { Função }\end{array}$ & $\begin{array}{c}\text { Número de peptídeos } \\
\text { encontrados na } \\
\text { imunoprecipitação / } \\
\text { Número peptídeos } \\
\text { encontrados no controle } \\
\text { negativo) } \\
\end{array}$ \\
\hline 1 & $\begin{array}{c}\text { Proteína } \\
\text { ribossômica } \\
\text { 60S L40/UBI } \\
\text { putativa }\end{array}$ & PF13_0346 & 14 & Não & Não & $\begin{array}{c}\text { Tradução de } \\
\text { RNA }\end{array}$ & $16 / 4$ \\
\hline 2 & $\begin{array}{l}\text { Proteína de } \\
\text { ligação à } \\
\text { isoleucina, } \\
\text { tRNA ligase }\end{array}$ & PF13_0179 & 151 & Não & Não & $\begin{array}{c}\text { Tradução de } \\
\text { RNA }\end{array}$ & $8 / 2$ \\
\hline 3 & $\begin{array}{c}\text { Antígeno } \\
\text { associado à } \\
\text { membrana do } \\
\text { eritrócito }\end{array}$ & MAL7P1.12 & 263 & Não & $\operatorname{Sim}(2)$ & Desconhecido & $5 / 1$ \\
\hline 4 & $\begin{array}{c}\text { DNA helicase } \\
\text { dependente de } \\
\text { ATP }\end{array}$ & PF13_0330 & 54 & Não & Não & $\begin{array}{c}\text { Replicação de } \\
\text { DNA }\end{array}$ & $4 / 1$ \\
\hline 5 & $\begin{array}{c}\text { Proteína } \\
\text { conservada }\end{array}$ & PFC0435w & 154 & Sim & Não & Desconhecido & $4 / 1$ \\
\hline
\end{tabular}


Tabela 7 - Proteínas enriquecidas mais que 3 vezes em relação ao controle na imunoprecipitação utilizando o anticorpo anti-pfsr25.

(continuação)

\begin{tabular}{|c|c|c|c|c|c|c|c|}
\hline $\begin{array}{l}\text { Número } \\
\text { da } \\
\text { proteína }\end{array}$ & $\begin{array}{c}\text { Nome de } \\
\text { Proteína de } \\
P \text {. falciparum } \\
\text { Identificada }\end{array}$ & $\begin{array}{c}\text { Número de } \\
\text { Acesso } \\
\text { PlasmodB }\end{array}$ & $\begin{array}{l}\text { Peso } \\
\text { Molecular } \\
\text { da } \\
\text { Proteína } \\
\text { (kDa) }\end{array}$ & $\begin{array}{c}\text { Peptídeo } \\
\text { Sinal } \\
\text { predito? }\end{array}$ & $\begin{array}{c}\text { Domínios } \\
\text { Transmembrana } \\
\text { preditos? } \\
\text { (número) }\end{array}$ & $\begin{array}{l}\text { Possível } \\
\text { Função }\end{array}$ & $\begin{array}{c}\text { Número de peptídeos } \\
\text { encontrados na } \\
\text { imunoprecipitação / } \\
\text { Número peptídeos } \\
\text { encontrados no controle } \\
\text { negativo) }\end{array}$ \\
\hline 6 & $\begin{array}{c}\text { Fator de } \\
\text { iniciação da } \\
\text { tradução, } \\
\text { subunidade } 3\end{array}$ & PFE0885w & 84 & Não & Não & $\begin{array}{c}\text { Tradução de } \\
\text { RNA }\end{array}$ & $4 / 1$ \\
\hline 7 & $\begin{array}{c}\text { Proteína } \\
\text { semelhante à } \\
\text { dinamina }\end{array}$ & PF11_0465 & 96 & Não & Não & $\begin{array}{l}\text { Formação de } \\
\text { vesículas }\end{array}$ & $4 / 1$ \\
\hline 8 & $\begin{array}{c}\text { ATPase da } \\
\text { família cdc48 }\end{array}$ & PF07_0047 & 142 & Sim & $\operatorname{Sim}(1)$ & $\begin{array}{l}\text { Similaridade à } \\
\text { ATPase } \\
\text { transicional de } \\
\text { retículo } \\
\text { endoplasmátic } \\
\text { o (VCP), } \\
\text { Envolvida com } \\
\text { fusão } \\
\text { vesicular, } \\
\text { dobramento } \\
\text { proteico, } \\
\text { degradação } \\
\text { proteica }\end{array}$ & $3 / 1$ \\
\hline
\end{tabular}


Tabela 7 - Proteínas enriquecidas mais que 3 vezes em relação ao controle na imunoprecipitação utilizando o anticorpo anti-pfsr25

(continuação)

\begin{tabular}{|c|c|c|c|c|c|c|c|}
\hline $\begin{array}{c}\text { Número } \\
\text { da } \\
\text { proteína }\end{array}$ & $\begin{array}{c}\text { Nome de } \\
\text { Proteína de } \\
P \text {. falciparum } \\
\text { Identificada }\end{array}$ & $\begin{array}{l}\text { Número de } \\
\text { Acesso } \\
\text { PlasmodB }\end{array}$ & $\begin{array}{c}\text { Peso } \\
\text { Molecular } \\
\text { da } \\
\text { Proteína } \\
\text { (kDa) }\end{array}$ & $\begin{array}{c}\text { Peptídeo } \\
\text { Sinal } \\
\text { predito? }\end{array}$ & $\begin{array}{c}\text { Domínios } \\
\text { Transmembrana } \\
\text { preditos? } \\
\text { (número) }\end{array}$ & $\begin{array}{l}\text { Possível } \\
\text { Função }\end{array}$ & $\begin{array}{c}\text { Número de peptídeos } \\
\text { encontrados na } \\
\text { imunoprecipitação / } \\
\text { Número peptídeos } \\
\text { encontrados no controle } \\
\text { negativo) }\end{array}$ \\
\hline 9 & $\begin{array}{c}\text { DNA helicase } \\
\text { dependente de } \\
\text { ATP }\end{array}$ & PF13_0330 & 54 & Não & Não & $\begin{array}{c}\text { Replicação de } \\
\text { DNA }\end{array}$ & $3 / 1$ \\
\hline 10 & Miosina A & PF13_0233 & 92 & Não & Não & $\begin{array}{l}\text { Tráfego de } \\
\text { vesículas }\end{array}$ & $3 / 1$ \\
\hline 11 & $\begin{array}{c}\text { Fator de } \\
\text { iniciação da } \\
\text { tradução } \\
\text { eucariótico } 3 \\
\text { subunidade } 5\end{array}$ & PFI0895c & 36 & Não & Não & $\begin{array}{c}\text { Tradução de } \\
\text { RNA }\end{array}$ & $3 / 1$ \\
\hline 12 & $\begin{array}{c}\text { Enzima } \\
\text { ativadora de } \\
\text { ubiquitina E1 } \\
\text { ligase }\end{array}$ & PFL1245w & 131 & Não & Não & $\begin{array}{l}\text { Diversos } \\
\text { processos }\end{array}$ & $3 / 1$ \\
\hline 13 & $\begin{array}{l}\text { Sintetase de } \\
\text { glutaminil } \\
\text { tRNA }\end{array}$ & PF13_0170 & 108 & Não & Não & $\begin{array}{l}\text { Tradução de } \\
\text { RNA }\end{array}$ & $3 / 1$ \\
\hline 14 & $\begin{array}{l}\text { Subunidade de } \\
\text { Cochaperona }\end{array}$ & PF11_0292 & 29 & Não & Não & Desconhecida & $3 / 1$ \\
\hline
\end{tabular}


Tabela 7 - Proteínas enriquecidas mais que 3 vezes em relação ao controle na imunoprecipitação utilizando o anticorpo anti-pfsr25

(conclusão)

\begin{tabular}{ccccccc}
\hline $\begin{array}{c}\text { Número } \\
\text { da } \\
\text { proteína }\end{array}$ & $\begin{array}{c}\text { Nome de } \\
\text { Proteína de } \\
\begin{array}{r}\text { f falciparum } \\
\text { Identificada }\end{array}\end{array}$ & $\begin{array}{c}\text { Número de } \\
\text { Acesso } \\
\text { PlasmodB }\end{array}$ & $\begin{array}{c}\text { Peso } \\
\text { Molecular } \\
\text { da } \\
\text { Proteína } \\
\text { (kDa) }\end{array}$ & $\begin{array}{c}\text { Peptídeo } \\
\text { Sinal } \\
\text { predito? }\end{array}$ & $\begin{array}{c}\text { Nomínios } \\
\text { Transmembrana } \\
\text { preditos? } \\
\text { (número) }\end{array}$ & $\begin{array}{c}\text { Nossível } \\
\text { Função de peptídeos } \\
\text { encontrados na } \\
\text { imunoprecipitação / } \\
\text { Número peptídeos } \\
\text { encontrados no controle } \\
\text { negativo) }\end{array}$ \\
\hline 15 & PfPAST-1 & PFC0190c & 62 & Não & Não & $\begin{array}{c}\text { Similaridade a } \\
\text { EHD2, } \\
\text { proteína } \\
\text { envolvida com } \\
\text { endocitose }\end{array}$ \\
\hline
\end{tabular}




\section{DISCUSSÃO}

\subsection{Receptor serpentino putativo PFSR10}

\subsubsection{Expressão e localização de pfsr10 em fases sanguíneas de P. falciparum}

PFSR10, identificado por análise in silico em Plasmodium como um receptor serpentino, possui um domínio da família de receptores órfãos de pulmão, sugerindo fortemente a classificação de PFSR10 como um 7-TMR (Madeira et al., 2008). Utilizando um anticorpo policlonal contra uma porção N-terminal de pfsr10 conseguimos identificar a expressão da proteína em fases intraeritrocíticas do parasita (Figura 7 A). Não é intrigante que a proteína pfsr10 seja expressa nesses estágios, já que experimentos de PCR em tempo real mostraram que o transcrito de PFSR10 está presente em todos os estágios intraeritrocíticos (Madeira et al., 2008).

Quando executamos o western blot em condições menos denaturantes, verificamos que pfsr10 pode formar oligômeros (Figura 7 B). Alternativamente, pfsr10 pode interagir com outras proteínas formando complexos de maior tamanho molecular (Figura 7 B). É conhecido que receptores serpentinos podem interagir entre si durante a exportação para a membrana plasmática (revisado em Gurevich e Gurevich, 2008). Além disso, a dimerização também pode alterar a farmacologia dos receptores (revisado em Gonzalez-Maeso, 2011).

Em fases de merozoíto e anel (Figura 8), verificamos que existe uma boa colocalização de pfsr10 com a membrana plasmática do parasita. Por outro lado, nas fases de esquizonte jovem e esquizonte tardio, a colocalização não é observada (Figura 9). A proteína pfsr10 entra na via de exportação via reticulo endoplasmático, pois Brefeldina A altera a distribuição intracelular do receptor putativo na fase de anel (Figura 11). Além disso, a entrada de pfsr10 na via de exportação é predita pela análise in silico, pois pfsr10 possui um peptídeo sinal de exportação. Esses dados em conjunto sugerem que há um tráfego do receptor putativo através de transporte vesicular para a membrana do parasita e também indicam que pode haver endocitose do receptor. A endocitose de receptores serpentinos é importante nos processos de dessensibilização e ativação de outras vias de sinalização celular (revisado em Lefkowitz, 2007).

A proteína msp1, que reconhecidamente está presente na superfície do parasita durante as fases tardias do desenvolvimento intraeritrocítico (Dluzewski et al., 2008) e durante a fase de 
merozoíto (Heidrich et al., 1986) foi utilizada como marcador da membrana plasmática nessas fases. É conhecido que a proteína msp1 é sintetizada, em esquizontes, em um tamanho de 200 $\mathrm{kDa}$, ancorada a membranas do parasita através de GPI e processada em tamanhos menores no esquizonte maduro (revisado em Holder et al., 1992). Durante a invasão, grande parte de msp1 é clivada e apenas um fragmento de $19 \mathrm{kDa}$ é mantido ligado à membrana plasmática do parasita (Blackman et al., 1990). Durante a fase de trofozoíto, a proteína msp1 é endocitada e passa a colocalizar com a membrana do vacúolo parasitóforo (Dluzewski et al., 2008). Em nosso experimento de imunofluorescência, observamos que o anticorpo anti-msp1 identifica preferencialmente uma proteína na periferia do parasita nas fases de esquizonte, merozoíto e anel, proteína que passa a localizar-se no entorno do vacúolo parasitóforo na fase de trofozoíto (Figuras 8 e 9). Assim sendo, temos evidência que o anticorpo anti-msp1 utilizado no ensaio de imunofluorescência esteja efetivamente reconhecendo a proteína msp1.

A localização subcelular diferencial de pfsr10 durante as fases intraeritrocíticas é interessante do ponto de vista funcional, sugerindo que pfsr10 pode participar de diferentes processos durante diferentes fases eritrocíticas do parasita.

\subsubsection{Anticorpo anti-pfsr10: invasão e desenvolvimento intraeritrocítico de P. falciparum}

Alguns anticorpos contra 7-TMR podem funcionar como agonistas (By et al., 2009; Elies et al., 1998; Lebesgue et al., 1998) ou antagonistas (Goetzl et al., 2004) desses receptores, ou seja, podem aumentar ou diminuir a atividade de 7-TMR. Além disso, anticorpos podem impedir que proteínas de membrana do parasita reconheçam ligantes da célula hospedeira durante a invasão. Esse é o caso para anticorpos anti-msp1, que impedem invasão de hemácias por merozoítos de P. falciparum (Moss et al., 2012). Como pfsr10 é expresso na superfície de merozoítos (Figura 8), forma infectiva de hemácias, decidimos incubar fases maduras do parasita com pfsr10 e observar se havia efeito sobre a invasão. Porém não observamos diferença estatística de parasitemia ou distribuição de fases em nenhuma condição de incubação (Figura 12). Assim sendo, esse experimento não nos ofereceu evidências de um eventual envolvimento de pfsr10 no processo de invasão de hemácias pelo parasita. O resultado não exclui a possibilidade de pfsr10 ter um papel neste processo, uma vez que o anticorpo pode estar interagindo com uma região que não é importante para a atividade do receptor. 


\subsubsection{Expressão de pfsr10 em sistema heterólogo}

A dificuldade em expressar receptores serpentinos em sistema heterólogo é conhecida (revisado em Dunham e Hall, 2009). Muitos receptores serpentinos transfectados não localizam com a membrana plasmática, sendo retidos na via exocítica (revisado em Dunham e Hall, 2009). Diversas estratégias são utilizadas para melhorar a localização de receptores com a membrana plasmática, incluindo coexpressão com chaperonas, remoção de parte da sequência da proteína ou adição de um peptídeo sinal à proteína (revisado em Dunham e Hall, 2009). Outro problema enfrentado ao se expressar proteínas em sistema heterólogo, particularmente proteínas de membrana, é conseguir que a proteína adquira uma conformação nativa.

No caso de pfsr10, experimentos de western blot são capazes de detectar a proteína em extratos celulares, porém há também a detecção de diversas bandas inespecíficas (resultados não mostrados). Importante mencionar que o anticorpo utilizado nesse caso, anti-flag, é monoclonal e altamente específico. Além disso, o plasmídeo utilizado para expressar pfsr10 em sistema heterólogo possui um promotor de expressão forte. Assim, o esperado seria que pfsr10 fosse detectado em experimentos de western blot como banda única. Como este não é o caso, é possível hipotetizar que grande parte de pfsr10 sintetizado seja degradado. Para comprovar, indubitavelmente, que pfsr10 é expresso em sistema heterólogo no tamanho esperado, imunoprecipitamos pfsr10, o que promoveu um enriquecimento do receptor putativo, e executamos o western blot a partir da imunoprecipitação, utilizando dois anticorpos diferentes, direcionados para as porções N- e C- terminal de pfsr10. Os resultados são claros em mostrar que pfsr10 é expresso em HEK293T no tamanho predito (Figura 15).

Quanto à localização subcelular de pfsr10, observamos que parte da proteína é intracelular, porém também podemos concluir, objetivamente, através de colocalização de pfsr10 com aglutinina fluorescente, que parte do receptor putativo é translocado para a membrana plasmática (Figura 14).

Os resultados de expressão em sistema heterólogo possibilitaram prosseguir para experimentos de caracterização funcional do receptor serpentino putativo. 


\subsubsection{Ensaios de $\left[\mathrm{Ca}^{2+}\right]_{\text {cit }}$ com nucleotídeos em células HEK293T-PFSR10+Ga $\alpha_{15}$}

A proteína pfsr10 possui sete domínios transmembrânicos, um peptídeo sinal preditos in silico e um domínio da família de receptor serpentino de pulmão (Madeira et al., 2008). Essas observações permitem considerar pfsr10 um bom candidato a receptor de sete domínios transmembrânicos, que são classicamente acoplados a proteína G (revisado em Lefkowitz, 2007). Interessantemente, $P$. falciparum não possui proteína $\mathrm{G}$ predita em seu genoma através de análise de similaridade, porém existem evidências experimentais de que proteínas $\mathrm{G}$ existam no parasita (Dyer e Day 2000) Além disso, novas vias de sinalização independentes de proteína G e ativadas por receptores serpentinos vêm sendo descritas (revisado em Lefkowitz, 2007).

A fim de caracterizar funcionalmente pfsr10, utilizamos um ensaio fluorimétrico de detecção da concentração do segundo mensageiro intracelular cálcio, detectando o aumento do íon após a adição de agonistas.

Estudos demonstraram a importância de nucleotídeos na invasão de células hospedeiras por Plasmodium (Levano-Garcia et al., 2010; Ono et al., 2008) e no aumento de atividade proteolítica e cálcio intracelular (da Cruz et al., 2012). Decidimos, assim, selecionar nucleotídeos entre os agonistas utilizados para caracterização funcional de pfsr10. Interessantemente, em células de mamíferos cotransfectadas com PFSR10 e $\mathrm{G} \alpha_{15}$ observamos aumento de cálcio citosólico estatisticamente maior em relação aos controles, quando estimulamos células com ATP, GTP e UTP (Figura 16 D). Na ausência de cálcio extracelular ou em transfecções apenas com PFSR10, a diferença estatística não foi observada (Figura 16 D), sugerindo influxo de cálcio a partir do meio extracelular e participação de proteína G na transdução de sinal de pfsr10. Além disso, adenosina não foi capaz de promover aumento de cálcio na transfecção com PFSR10 e $\mathrm{G} \alpha_{15}$ na presença de cálcio extracelular (Figura 16 D). Há evidências de que Plasmodium falciparum possua receptores purinérgicos, ativados por ATP e UTP e dependentes de cálcio extracelular, o que sugere a presença de receptores purinérgicos do tipo canal com farmacologia parecida a pfsr10 (Levano-Garcia et al., 2010).

Como a linhagem celular HEK293T possui uma alta resposta endógena a nucleotídeos, decidimos transfectar PFSR10 na linhagem celular 1321N1, comumente utilizada para ensaios com receptores purinérgicos por possuir baixa resposta endógena a nucleotídeos (Filtz et al., 1994). Não observamos aumento de cálcio em resposta a ATP quando transfectamos PFSR10 e 
G $\alpha_{15}$ nessas células (Figura 18), porém tampouco observamos localização de pfsr10 com a membrana plasmática em 1321N1, e a expressão de pfsr10 era baixa (Figura 18). É possível que pfsr10 seja tóxico a essas células ou que o dobramento de pfsr10 não ocorra de maneira correta, levando à degradação do receptor.

Podemos hipotetizar dois mecanismos funcionais para pfsr10: o receptor serpentino putativo poderia ligar nucleotídeos e ativar uma proteína $\mathrm{G}$, que levaria à ativação de canais de cálcio de membrana plasmática endógenos (Figura 37 A) ou pfsr10 poderia ser um canal de cálcio de membrana plasmática aberto por nucleotídeos (Figura 37 B). Quando analisamos a segunda hipótese, poderíamos, em um primeiro momento, tentar classificar pfsr10 como um receptor purinérgico do tipo P2X (revisado em Burnstock, 2007). Porém, receptores desse tipo não apresentam resposta a UTP (revisado em Burnstock, 2007), ao passo que pfsr10 apresenta resposta ao nucleotídeo, o que credita pfsr10 a ser incluído em uma nova classe de receptores.

É especialmente interessante pfsr10 gerar aumento de cálcio intracelular a partir do meio extracelular e, ao mesmo tempo, ter atividade dependente de $\mathrm{G} \alpha_{15}$. Em Drosophila, foi identificado um receptor olfativo de sete domínios transmembrana que possui atividade ionotrópica e, ao mesmo tempo, gera segundos-mensageiros através de proteína G (Wicher et al., 2008). A atividade ionotrópica desse receptor é dependente de um parceiro molecular que possui topologia de receptor de sete domínios transmembrânicos invertida e independente de GTP (Wicher et al., 2008).

Por fim, ensaios de binding com ATP em pfsr10 são interessantes para dar suporte aos ensaios funcionais, bem como ensaios de eletrofisiologia, que poderão oferecer evidências sobre uma eventual natureza ionotrópica de pfsr10. Para tanto, conseguir a expressão de pfsr10 em um sistema sem receptores purinérgicos endógenos é fundamental. 
Figura 37 - Hipóteses sobre a natureza molecular de pfsr10.

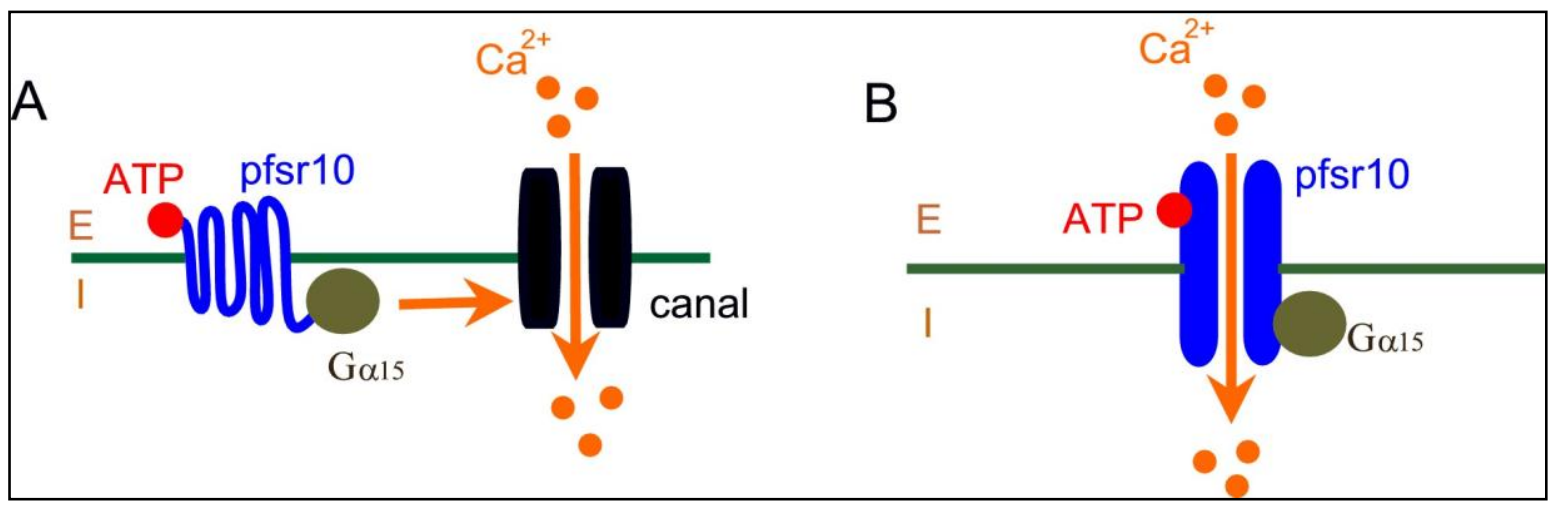

A: pfsr10 como um receptor de sete domínios transmembrânicos ativado por ATP, ligado a proteína $\mathrm{G} \alpha$ que ativa um canal edógeno de cálcio de membrana plasmática em células HEK293T. B: pfsr10 como um canal de membrana dependente de proteína $\mathrm{G} \alpha$, aberto por ATP. E: meio extracelular, I: meio intracelular, $\mathrm{G} \alpha_{15}$ : proteína $\mathrm{G}$, subunidade $\alpha_{15}$ (promíscua).O traço verde representa a membrana plasmática.

\subsubsection{Fosforilação em HEK293T-PFSR10+Ga $\alpha_{15}$}

O processo de fosforilação de proteínas é universalmente utilizado para alterar atividade enzimática, ligação a parceiros moleculares e localização celular (revisado em Tan, 2011). A fosforilação de proteínas é utilizada em vias de transdução de sinal, nas quais a dessensiblilização de receptores (Lefkowitz, 2007) modulação da abertura de canais iônicos (Scheuer, 2011) ativação de fatores de transcrição (Chang Foreman et al., 2012) entre outros podem ser reguladas por fosforilação.

Quando PFSR10 e $\mathrm{G} \alpha_{15}$ foram cotransfectados em células HEK293T observou-se um aumento na fosforilação basal de algumas proteínas da célula (Figura 21 A, B). É conhecido que receptores serpentinos oscilam entre diversas conformações, algumas ativas e outras inativas, possuindo, portanto, atividade constitutiva. Conformações ativas são estabilizadas através da ligação de agonistas (revisado em Vauquelin e Van Liefde, 2005). O aumento da fosforilação basal de proteínas após cotransfecção de PFSR10 e $\mathrm{G} \alpha_{15}$ sugere que o candidato a receptor serpentino PFSR 10 possa ter uma atividade basal. Por outro lado, é conhecido que ATP pode ser liberado de células através da lise das mesmas (revisado em Burnstock e Verkhratsky, 2009) e, portanto, não se pode excluir que ATP tenha estimulado a maior fosforilação de proteínas em células HEK293T-PFSR10+G $\alpha_{15}$. 
Quando estimulamos com ATP células HEK293T-PFSR10+G $\alpha_{15}$ observamos que o aumento de fosforilação dessas células, em alguns casos, tem tendência a ser menor que o aumento de fosforilação de células transfectadas com HEK293T-vazio+G $\alpha_{15}$ (Figura 20 A, Figura 20 B, banda entre $130 \mathrm{kDa}$ e $170 \mathrm{kDa}$ ). Como já existe uma fosforilação basal maior em células HEK293T-PFSR10+G $\alpha_{15}$ em relação a células HEK293T-vazio+G $\alpha_{15}$ (Figura 21), podese sugerir que o número de sítios disponíveis para fosforilação no primeiro caso são menores, o que impede um grande aumento na fosforilação nesse caso.

As bandas selecionadas para análise de fosforilação provavelmente incluem mais de uma proteína, pois o SDS-PAGE foi corrido em apenas uma dimensão. Assim, não é possível identificar a identidade molecular das proteínas fosforiladas. Como havia indicação de que a cotransfecção de PFSR10 e $\mathrm{G} \alpha_{15}$ causa aumento de fosforilação de proteínas e de que MAPKs são fosforiladas via ativação de receptores serpentinos (revisado em Seger e Krebs 1995) decidimos verificar se MAPKs eram ativadas pela cotransfecção de PFSR10 e Ga $\alpha_{15}$ e estímulo com ATP. Porém, não foi detectada fosforilação evidente de MAPKs em nenhuma das condições

(Figura 22). É conhecido que a fosforilação de MAPKs ativado via proteína G é transiente e esperada durante os primeiros minutos de estímulo (Shenoy et al., 2006). Assim sendo, o estímulo de 10 minutos pode ter sido demasiado para detectar fosforilação da MAPK. Por outro lado, a fosforilação de MAPK via beta arrestina ocorre após os primeiros minutos de estímulo (Shenoy et al., 2006) e nesse caso deveria ser observada no experimento. Nossos dados não oferecem evidências de que MAPKs sejam ativadas pela cotransfecção de PFSR10 e G $\alpha_{15}$ ou pelo estímulo com ATP em células HEK293T.

As quinases e fosfatases de $P$. falciparum são diferentes daquelas expressas em células de mamíferos. Porém, a capacidade de pfsr10 aumentar a fosforilação em células transfectadas (Figura 21) é um indicativo de que o receptor esteja envolvido na promoção de fosforilação no parasita.

\subsubsection{Imunoprecipitação de candidatos a parceiros moleculares de pfsr10 em P. falciparum}

Com a finalidade de identificar parceiros moleculares de pfsr10, imunoprecipitamos o candidato a receptor serpentino utilizando anticorpo anti-pfsr10 e comparamos as proteínas identificadas com as proteínas obtidas em um controle negativo. A imunoprecipitação de 
candidatos a parceiros moleculares de pfsr10 sugere que o receptor pode interagir com um grande número de proteínas de diversas funções celulares (Tabela 2, Tabela 3). Não é surpreendente a identificação de proteínas tão diversas, pois para a imunoprecipitação foram utilizadas fases de trofozoíto, esquizonte jovem e esquizonte maduro, fases que estão comprometidas com diferentes processos celulares, como crescimento, divisão celular, evasão da célula hospedeira e invasão da célula hospedeira. Além disso, o grande número de proteínas identificadas também poderia ser explicado por interações indiretas de pfsr10 com alguns dos candidatos.

As proteínas identificadas puderam ser divididas em subgrupos de acordo com o processo celular em que participam. As diversas proteínas relacionadas com tradução de RNA encontradas são comuns à síntese de proteínas e espera-se que interajam com pfsr10.

As chaperonas encontradas ajudam no dobramento de diversas classes de proteínas, incluindo fatores de transcrição, receptores nucleares e proteínas relacionadas a via secretória (revisado em Taipale et al., 2010). Como o processo de dobramento de proteínas é geral, a coimunoprecipitação de chaperonas e pfsr10 não é surpreendente.

Proteínas relacionadas com os processos celulares de endocitose, exocitose, invasão e estabelecimento na célula hospedeira chamam atenção, por serem associados especificamente com proteínas exportadas. Existem fortes indícios de que o receptor serpentino putativo pfsr10 entra na via de exportação de proteínas, pois possui um peptídeo sinal e sete domínios transmembrânicos (Madeira et al., 2008). Além disso, o uso de Brefeldina A retém a exportação de pfsr10 (Figura 11), sugerindo que a proteína trafega via retículo endoplasmático. Existem também evidências de que pfsr10 possa interagir com proteína relacionada à ubiquitinação. A ubiquitinação de receptores serpentinos é um processo comum para dessensibilização da via clássica de sinalização através de proteína $\mathrm{G}$ e promove a endocitose dos receptores, levando à ativação de outras vias de sinalização em mamíferos (revisado em Lefkowitz, 2007). Importante mencionar que a proteína Rab5a, relacionada com tráfego de proteínas para o endossomo inicial, é um candidato a parceiro molecular de pfsr10. O receptor pode seguir dois caminhos: ser deubiquitinado e reciclado para a membrana plasmática ou degradado via lisossomo (revisado em Hislop e von Zastrow, 2011). Por outro lado, a ubiquitinação possui várias outras funções celulares, como degradação de proteínas com dobramento incorreto, também uma possibilidade para a ubiquitinação do receptor. É interessante notar que pfsr10 colocaliza com a membrana do parasita nas fases de anel e merozoíto de $P$. falciparum e parece ter localização intracelular 
durante trofozoítos e esquizontes (Figuras 8 e 9), sugerindo que a exista efetivamente endocitose de pfsr10 entre as fases de anel e trofozoíto.

Proteínas com função predita de saída e invasão de eritrócitos por P.falciparum (EBA175, M18 aspartil amiopeptidase, RESA, Miosina A, CDPK1, SERA-6, RON-4, RON-5, Tabela 2 e Tabela 3) são candidatas interessantes à interação com pfsr10, já que outras observações nos permitem hipotetizar que pfsr10 possa estar relacionado à função de invasão. O processo de invasão de eritrócitos por merozoítos de P. falciparum é dependente de ATP (Levano-Garcia et al., 2010) e existem evidências de que pfsr10 participe na via de transdução de sinal induzida pelo nucleotídeo (Figura 16). A proteína CDPK1, em particular, é um efetor da via do cálcio, que é aumentado no citosol do parasita após adição de ATP extracelular.

Utilizando um anticorpo anti-pfsr10, não obtivemos evidências de que pfsr10 estivesse relacionado à invasão (Figura 12). Apesar disso, não se pode concluir o contrário, já que a porção da proteína a que anti-pfsr10 se liga pode não ser essencial para o processo de invasão de eritrócitos.

Por fim, é importante evidenciar que o método utilizado para a imunoprecipitação de parceiros moleculares de pfsr10 foi bastante adstringente. Apesar disso, é provável que algumas das proteínas candidatas a interação com pfsr10 sejam falsos positivos. Esse pode ser o caso de algumas proteínas nucleares relacionadas à transcrição ou replicação do DNA como helicases e ligases, já que a proteína pfsr10 não colocaliza com o núcleo. Uma possibilidade é que essas proteínas tenham sido imunoprecipitadas devido a sua grande abundância celular.

Por outro lado, não se pode descartar a possibilidade de que fatores de transcrição possam ser translocados para o núcleo a partir do citosol. Para separar falsos positivos de interações reais é importante que seja executada a imunoprecipitação das proteínas candidatas com anticorpos específicos com posterior western blot do imunoprecipitado utilizando anticorpo anti-pfsr10.

Em resumo, nós identificamos algumas proteínas que podem interagir com pfsr10. Esta identificação e a validação destes parceiros podem resultar em um melhor entendimento sobre a atividade deste receptor e também um quadro mais completo sobre a sua função celular e/ou regulação. 


\subsubsection{Imunoprecipitação de parceiros moleculares de pfsr10 em P. falciparum após estímulo com ATP}

Como temos evidência de que pfsr10 esteja envolvido na sinalização via ATP (Figura 16), decidimos verificar se algum fator de P. falciparum era capaz de interagir com pfsr10 após estímulo com o nucleotídeo, utilizando para tanto fases maduras do parasita isoladas da célula hospedeira.

Esperávamos observar bandas presentes no tratamento com ATP e ausentes no controle negativo, porém isso não foi observado (Tabela 4). Uma possibilidade é a de que durante a lise dos eritrócitos para isolar parasitas, ATP tenha sido liberado do citosol da célula hospedeira estimulando ambos os grupos de parasitas (experimental e controle negativo) e diminuindo o poder da análise. Apesar disso, uma proteína de função desconhecida (número de acesso do PlasmoDB PF14_0191) foi enriquecida no tratamento com ATP (Tabela 4). A proteína hsp70 (número de acesso do PlasmoDB PF08_0054) também é uma candidata para interação com pfsr10 após estímulo com ATP, já que o número de peptídeos identificados é duas vezes maior no tratamento com o nucleotídeo em relação ao controle negativo (Tabela 4). Não é clara a razão pela qual a interação entre pfsr10 e hsp70 seja aumentada após estímulo com ATP. Por outro lado, deve-se ter em mente que para um 7-TMR transmitir um sinal extracelular para dentro da célula ele deve ser transportado para a superfície celular. Já foi demonstrado que o processamento de 7-TMR é influenciado por diversas proteínas acessórias (revisado em Tan et al., 2004), sendo que algumas destas proteínas têm função de chaperona. Tem-se tornado evidente que hsp70 desempenha uma importante função no transporte de 7-TMR para a membrana celular (Neuhaus et al., 2006). Estes dados sugerem que estas proteínas podem estar desempenhando função semelhante para o correto transporte de pfsr10.

\subsection{Receptor serpentino putativo PFSR25}

\subsubsection{Expressão de pfsr25 em P. falciparum}

Os resultados de expressão em Plasmodium falciparum para pfsr25 demonstram

claramente que o receptor putativo é expresso principalmente nas fases intraeritrocíticas de 
trofozoíto e esquizonte (Figura 25 e Figura 26). Assim sendo, é provável que pfsr25 exerça suas funções durante esses estágios de desenvolvimento. Além disso, pfsr25 colocaliza parcialmente com a membrana plasmática de fases maduras de Plasmodium falciparum (Figura 27), o que está de acordo com o predito pela análise in silico, que identificou um peptídeo sinal em pfsr25 (Madeira et al., 2008).

\subsubsection{Anticorpo anti-pfsr25 e invasão de hemácias por P. falciparum}

Tendo em vista que possuímos evidências de que $\mathrm{KCl}$ esteja envolvido com a saída de esquizontes de P. falciparum de hemácias (Figura 35), que pfsr25 está envolvido com a percepção de $\mathrm{KCl}$ (Figura $34 \mathbf{H}$ ) e que anticorpos podem interferir com atividade de receptores (By et al., 2009; Elies et al., 1998; Goetzl et al., 2004; Lebesgue et al., 1998) resolvemos verificar se o anticorpo anti-pfsr25 poderia influenciar na progressão do ciclo intraeritrocítico de $P$. falciparum (Figura 28).

Os resultados obtidos em esquizontes incubados com anticorpo anti-pfsr 25 não oferecem evidências da importância do receptor putativo no ciclo intraeritrocítico de $P$. falciparum (Figura 28). Porém, é necessário considerar que o epítopo utilizado como indutor do anticorpo pode não ser essencial para a função de pfsr25.

\subsubsection{Expressão de pfsr25 em sistema heterólogo}

Apesar dos problemas comumente enfrentados para expressar receptores serpentinos em sistema heterólogo, como exportação fraca para a membrana plasmática e dobramento incorreto da proteína, observamos que há colocalização parcial de pfsr25 com a membrana plasmática de células HEK293T (Figura 30), bem como o tamanho predito de pfsr25, de aproximadamente 40 $\mathrm{kDa}$, foi observado em experimentos de imunoprecipitação com posterior detecção através de western blot (Figura 31). Os resultados possibilitaram prosseguir com a caracterização funcional de pfsr25. 


\subsubsection{Ensaios de cálcio em células HEK293T transfectadas com PFSR25 e estimuladas com $\mathrm{KCl}$}

A importância do $\mathrm{KCl}$ no ciclo de vida de $P$. falciparum foi reportada por diferentes grupos (Kumar et al., 2007; Ono et al., 2008; Singh et al., 2010). KCl é capaz de aumentar a infectividade de hepatócitos por esporozoítos (Kumar et al., 2007; Ono et al., 2008). Além disso, os inibidores de canais de potássio de membrana plasmática cloroquina e TEA inibem o aumento da invasão de hepatócitos por esporozoítos, mostrando que canais iônicos de membrana plasmática estão envolvidos no processo (Kumar et al., 2007). Em outro parasita do filo Apicomplexa, Toxoplasma gondii, a diminuição da concentração de $\mathrm{KCl}$ na célula hospedeira é responsável pela ruptura da mesma pelo parasita, processo que depende de cálcio intracelular e fosfolipase C (Fruth e Arrizabalaga, 2007; Moudy et al., 2001).

Nossos experimentos em sistema heterólogo demonstraram que pfsr25 está envolvido com a percepção de $\mathrm{KCl}$ extracelular (Figura 32 A, E). Além disso, o sinal de $\left[\mathrm{Ca}^{2+}\right]_{\text {cit }}$ em células HEK293T-PFSR25 promovido por $\mathrm{KCl}$ é dependente de influxo de cálcio extracelular e de canais iônicos de cálcio e/ou potássio na membrana plasmática (Figura 32 C-E).

Os experimentos com parasitas nocaute para PFSR25 indicam fortemente que pfsr25 seja um sensor de $\mathrm{KCl}$ (Figura $34 \mathbf{H}$ ), porém o exato mecanismo de ativação do receptor não foi definido através dos experimentos de dinâmica de $\left[\mathrm{Ca}^{2+}\right]_{\mathrm{cit}}$ em sistema heterólogo.

Não seria surpreendente que pfsr25 fosse um receptor serpentino que tivesse como ligante o íon potássio (Figura 38 A, B). Existem receptores serpentinos de íons, como o receptor serpentino sensor de cálcio, que pode ser ativado por diversos cátions divalentes (revisado em Magno et al., 2011). Além disso, pode-se hipotetizar que pfsr25 seja ativado por uma despolarização induzida pela entrada de $\mathrm{K}^{+}$a partir do meio extracelular (Figura 38 C, D). Existe ao menos um exemplo de receptor serpentino ativado através dessa maneira: o receptor muscarínico do subtipo 3 é capaz de ser ativado por despolarização de membrana, transduzindo o sinal através de uma proteína $\mathrm{G}$ e promovendo aumento de cálcio a partir de estoques internos (Liu et al., 2009).

Receptores serpentinos também podem levar à abertura de canais iônicos, independentemente de proteína G, seja através de interação e ativação de canais endógenos 
(Figura 38 A, C) ou formando, por si sós (Figura 38 B, D), canais iônicos ativados por um ligante (Wicher et al., 2008).

Existem, portanto, diversas possibilidades para a natureza molecular de pfsr25 (Figura 38 A-D). Para explorar a eventual natureza ionotrópica de pfsr 25 fazem-se necessários experimentos de eletrofisiologia. Experimentos de binding poderão indicar se pfsr25 liga $\mathrm{K}^{+}$. Esses experimentos são muito interessantes, pois possibilitam a melhor compreensão da sinalização de Plasmodium.

Figura 38 - Hipóteses para o mecanismo de ativação de pfsr25.

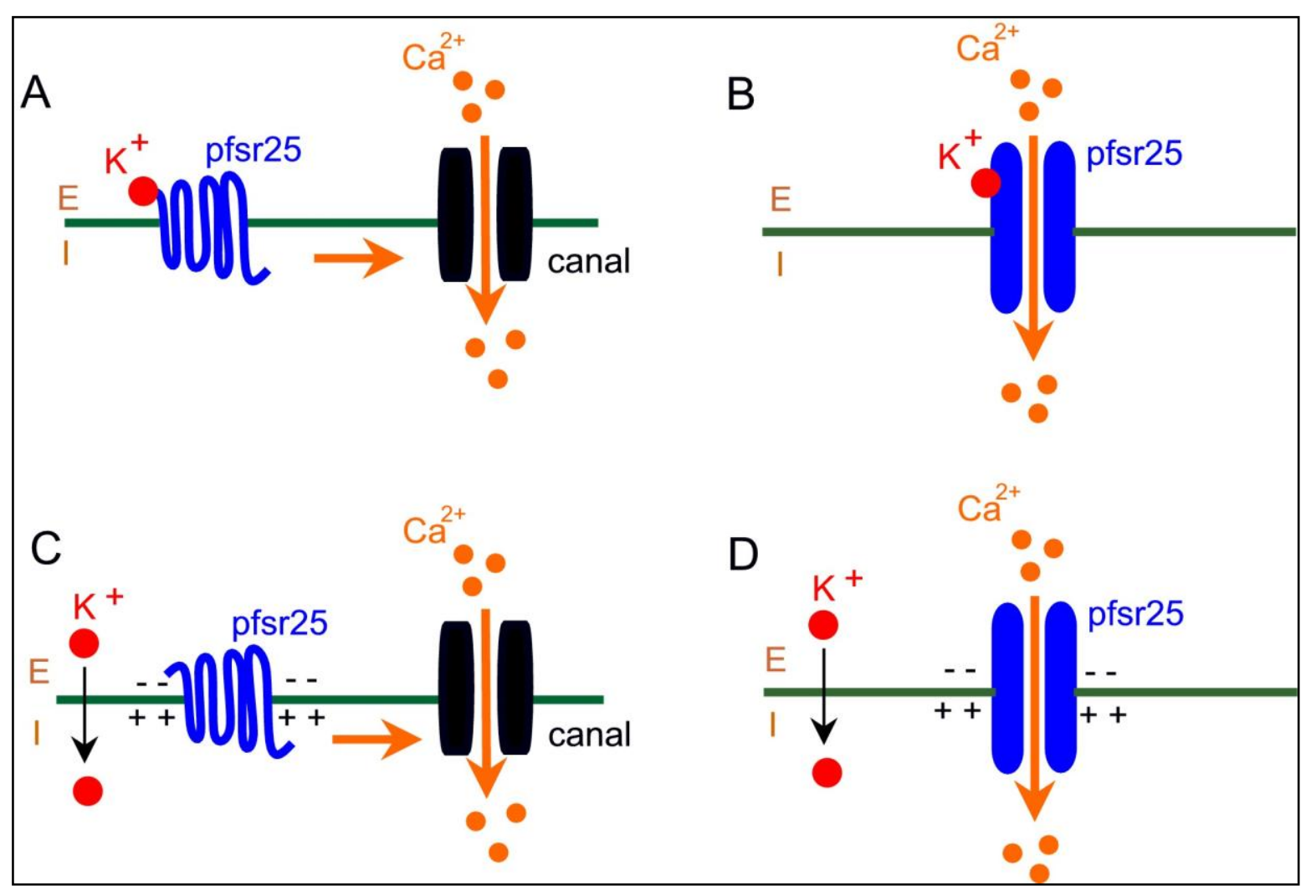

A: pfsr25 teria $\mathrm{K}^{+}$como ligante e ativaria um canal endógeno de cálcio de membrana plasmática. B: pfsr25 seria um canal de cálcio aberto pelo ligante $\mathrm{K}^{+}$. C: pfsr25 seria ativado pela despolarização da membrana plasmática e ativaria um canal endógeno de cálcio de membrana plasmática. D: pfsr25 seria um canal de cálcio ativado pela despolarização da membrana plasmática. E: meio extracelular, I: meio intracelular. $\mathrm{O}$ traço verde representa a membrana plasmática. 


\subsubsection{Sinalização de KCl em parasitas intraeritrocíticos}

Durante o desenvolvimento intraeritrocítico, $P$. falciparum é submetido a concentrações variáveis de potássio (Mauritz et al., 2010; Staines et al., 2001). No estágio inicial do desenvolvimento do parasita no interior do eritrócito, a concentração de $\mathrm{K}^{+}$no citosol do eritrócito é alta ( 140 mM), e a concentração de $\mathrm{Na}^{+}$é baixa ( $\sim \mathrm{mM}$, Mauritz et al., 2010). Durante o desenvolvimento intraeritrocítico do parasita, o citosol do eritrócito progressivamente perde $\mathrm{K}^{+}$e ganha $\mathrm{Na}^{+}$devido a um aumento da permeabilidade da membrana plasmática do eritrócito, induzida pelo parasita (Staines et al., 2001). O parasita intraeritrocítico se encontra separado do citosol do eritrócito através da membrana do vacúolo parasitóforo, que é permeável a moléculas grandes (Desai et al., 1993). Assim, é provável que o ambiente iônico do citosol do eritrócito possa ser percebido pelo parasita.

Em parasitas na fase de trofozoíto maduro, $\mathrm{KCl}$ promove um aumento de $\left[\mathrm{Ca}^{2+}\right]_{\mathrm{cit}}$ dependente de PLC a partir de estoques internos de cálcio (Figura 34 A-G). O aumento de $\left[\mathrm{Ca}^{2+}\right]_{\text {cit }}$ provocado por $\mathrm{KCl}$ também é dependente do receptor putativo pfsr 25 (Figura $34 \mathrm{H}$ ). Em experimentos em sistema heterólogo, pfsr25 parece se acoplar a uma maquinaria de sinalização que promove aumento de $\left[\mathrm{Ca}^{2+}\right]_{\text {cit }}$ a partir do meio extracelular (Figura 32), o que contrasta com os experimentos em parasitas $P$. falciparum. Porém a diferença não é completamente inesperada, já que diferentes proteínas relacionadas com transdução de sinal são expressas por diferentes células (revisado em Berridge et al., 2003). As diferenças na expressão de proteínas relacionadas à transdução de sinal podem ser ainda mais exacerbadas quando se considera a distância filogenética entre células de mamíferos e Plasmodium.

Quando incubamos o parasita em um meio rico em $\mathrm{KCl}(142 \mathrm{mM})$, isso provoca uma redução da proporção de fases maduras e um aumento da proporção de fases jovens (Figura 35 A). Em conjunto, esses dados indicam que $\mathrm{KCl}$ é importante no processo da saída de parasitas maduros de hemácias. Apesar disso, a saída de parasitas de eritrócitos provocada por $\mathrm{KCl}$ pode ser prematura, já que existe uma queda na parasitemia (Figura 35 B).

Singh et al. (2010) demonstraram que uma queda na concentração extracelular de $\mathrm{KCl}$ promove a mobilização da maquinaria celular de $P$. falciparum responsável pela invasão de eritrócitos. Nossos dados sugerem que, durante o ciclo intraeritrocítico, $\mathrm{KCl}$ participa na 
promoção da saída de parasitas das hemácias. O fato de parasitas nocaute para PFSR25 serem viáveis indica que existam mecanismos redundantes para as funções que pfsr25 desempenha.

\subsubsection{Imunoprecipitação de candidatos a parceiros moleculares de pfsr25 em P. falciparum}

Com a finalidade de identificar parceiros moleculares de pfsr25, imunoprecipitamos o candidato a receptor serpentino utilizando anticorpo anti-pfsr25 e comparamos as proteínas identificadas com as proteínas obtidas em um controle negativo. A imunoprecipitação de candidatos a parceiros moleculares de pfsr25 sugere que o receptor pode interagir com um grande número de proteínas de diversas funções celulares (Tabela 6, Tabela 7). Esse grande número de proteínas encontradas não é surpreendente, dado que foram utilizadas culturas que continham estágios de trofozoítos e esquizontes na imunoprecipitação, que possuem diferente expressão proteica.

Algumas proteínas puderam ser agrupadas de acordo com funções em processos celulares comuns. Alguns desses processos são gerais para proteínas, como dobramento proteico (Taipale et al., 2010). Proteínas identificadas relacionadas com outros processos, como endocitose e exocitose são bons candidatos para interação com pfsr25, já que pfsr25 deve passar pela via de exportação proteica (Madeira et al., 2008). Proteínas relacionadas com endocitose de pfsr25 são particularmente interessantes, já que endocitose é um processo de dessensibilização, ativação de outras vias de sinalização (revisado em Lefkowitz, 2007) ou mesmo degradação. Nesse último sentido, é importante notar que uma subunidade do proteassomo também foi encontrada na imunoprecipitação.

Proteínas relacionadas com o rompimento do eritrócito durante a saída de merozoítos são de particular interesse como bons candidatos a parceiros de pfsr25, já que temos evidências de que $\mathrm{KCl}$ promove um aumento de cálcio via pfsr25 em $P$. falciparum e também provoca evasão de parasitas de eritrócitos (Figura 34, Figura 35). A proteína M18 aspartil amiopeptidase, responsável pela fragilização da espectrina na saída de parasitas do eritrócito pode ser incluída nessa categoria.

As duas proteínas serina/tirosina fosfatases identificadas podem exercer funções de regulação da atividade enzimática de outras proteínas. Proteínas fosfatase podem estar envolvidas 
em vias de transdução de sinal, ligadas a outros componentes de sinalização, como receptores, via proteínas adaptadoras (Berridge, 2012).

É provável que muitos dos candidatos a interação com pfsr25 identificados sejam falsos positivos, apesar do método adstringente utilizado na imunoprecipitação. Para separar falsos positivos de interações reais é importante que seja executada a imunoprecipitação das proteínas candidatas com anticorpos específicos com posterior western blot do imunoprecipitado utilizando anticorpo anti-pfsr25. 


\section{CONCLUSÕES}

Os receptores serpentinos putativos pfsr10 e pfsr25 são expressos ao longo do ciclo eritrocítico. O receptor pfsr10 colocaliza com a membrana plasmática do parasita principalmente na fase de merozoíto e fases intraeritrocíticas jovens. PFSR25 colocaliza com a membrana plasmática do parasita em fases intraeritrocíticas maduras.

Ambos receptores possuem parceiros moleculares putativos que participam em funções celulares como invasão e saída de eritrócitos, estabelecimento no eritrócito infectado, endocitose e exocitose.

Em sistema heterólogo (células HEK293T), pfsr10 e pfsr25 colocalizam parcialmente com a membrana plasmática o que possibilita ensaios funcionais.

Ensaios em sistema heterólogo demonstraram que PFSR10 participa na percepção de ATP extracelular, enquanto PFSR25 é um sensor de KCl. Para PFSR25, experimentos com parasitas PFSR25 nocaute demonstram que o aumento de cálcio intracelular causado por $\mathrm{KCl}$ é abolido, o que corrobora a hipótese da função de PFSR25 como sensor de $\mathrm{KCl}$.

No caso do receptor putativo pfsr10, conseguir a expressão em um sistema heterólogo sem receptores purinérgicos endógenos é importante para claramente caracterizar ATP como um ligante para pfsr10.

Tendo em vista que existem poucos estudos sobre a função de 7-TMR em Plasmodium, diversas direções foram tomadas na tentativa de entender a importância de receptores serpentinos no ciclo celular do parasita. As evidências acumuladas apontam para uma nova função para estes receptores dentro do ciclo intraeritrocítico do parasita. Portanto, os resultados abrem novos caminhos para o entendimento sobre os mecanismos de desenvolvimento de P. falciparum e também na interação parasita hospedeiro. 


\section{REFERÊNCIAS*}

Acconcia F, Sigismund S, Polo S. Ubiquitin in trafficking: the network at work. Exp Cell Res. 2009;315(9):1610-8.

Agnandji ST, Lell B, Soulanoudjingar SS, Fernandes JF, Abossolo BP, Conzelmann C, Methogo BG, Doucka Y, Flamen A, Mordmuller B, Issifou S, Kremsner PG, Sacarlal J, Aide P, Lanaspa M, Aponte JJ, Nhamuave A, Quelhas D, Bassat Q, Mandjate S, Macete E, Alonso P, Abdulla S, Salim N, Juma O, Shomari M, Shubis K, Machera F, Hamad AS, Minja R, Mtoro A, Sykes A, Ahmed S, Urassa AM, Ali AM, Mwangoka G, Tanner M, Tinto H, D'Alessandro U, Sorgho H, Valea I, Tahita MC, Kabore W, Ouedraogo S, Sandrine Y, Guiguemde RT, Ouedraogo JB, Hamel MJ, Kariuki S, Odero C, Oneko M, Otieno K, Awino N, Omoto J, Williamson J, MuturiKioi V, Laserson KF, Slutsker L, Otieno W, Otieno L, Nekoye O, Gondi S, Otieno A, Ogutu B, Wasuna R, Owira V, Jones D, Onyango AA, Njuguna P, Chilengi R, Akoo P, Kerubo C, Gitaka J, Maingi C, Lang T, Olotu A, Tsofa B, Bejon P, Peshu N, Marsh K, Owusu-Agyei S, Asante KP, Osei-Kwakye K, Boahen O, Ayamba S, Kayan K, Owusu-Ofori R, Dosoo D, Asante I, Adjei G, Adjei G, Chandramohan D, Greenwood B, Lusingu J, Gesase S, Malabeja A, Abdul O, Kilavo H, Mahende C, Liheluka E, Lemnge M, Theander T, Drakeley C, Ansong D, Agbenyega T, Adjei S, Boateng HO, Rettig T, Bawa J, Sylverken J, Sambian D, Agyekum A, Owusu L, Martinson F, Hoffman I, Mvalo T, Kamthunzi P, Nkomo R, Msika A, Jumbe A, Chome N, Nyakuipa D, Chintedza J, Ballou WR, Bruls M, Cohen J, Guerra Y, Jongert E, Lapierre D, Leach A, Lievens M, Ofori-Anyinam O, Vekemans J, Carter T, Leboulleux D, Loucq C, Radford A, Savarese B, Schellenberg D, Sillman M Vansadia P. First results of phase 3 trial of RTS,S/AS01 malaria vaccine in African children. N Engl J Med. 2011;365(20):1863-75.

Akkaya C, Shumilina E, Bobballa D, Brand VB, Mahmud H, Lang F, Huber SM. The Plasmodium falciparum-induced anion channel of human erythrocytes is an ATP-release pathway. Pflugers Arch. 2009;457(5):1035-47.

Alves E, Bartlett PJ, Garcia CR, Thomas AP. Melatonin and IP3-induced $\mathrm{Ca}^{2+}$ release from intracellular stores in the malaria parasite Plasmodium falciparum within infected red blood cells. J Biol. Chem.. 2011;286(7):5905-12.

Amino R, Thiberge S, Martin B, Celli S, Shorte S, Frischknecht F, Menard R. Quantitative imaging of Plasmodium transmission from mosquito to mammal. Nature Med. 2006;12(2):220-4.

Arnold JD, Berger AE, Martin DC. Role of the endocrine system in controlling growth and division synchrony of Plasmodium berghei in mice. J Parasitol. 1969;55(5):956-62.

Bagnaresi P, Alves E, Borges da Silva H, Epiphanio S, Mota MM, Garcia CRS. Unlike the synchronous Plasmodium falciparum and $P$. chabaudi infection, the $P$. berghei and $P$. yoelii asynchronous infections are not affected by melatonin. Int J Gen Med. 2009;2:47-55

*De acordo com:

International Committee of Medical Journal Editors. [Internet]. Uniform requirements for manuscripts submitted to Biomedical Journal: sample references. [updated 2011 Jul 15]. Available from: http://www.icmje.org. 
Bagnaresi P, Markus RP, Hotta CT, Pozzan T, Garcia CR. Desynchronizing Plasmodium Cell Cycle Increases Chloroquine Protection at Suboptimal Doses. Open Parasitol J. 2008;2:55-8.

Bagnaresi P, Rodrigues MT, Garcia CR. Calcium signaling in lizard red blood cells. Comp Biochem Physiol. 2007;147(3):779-87.

Bannister L, Mitchell G. The ins, outs and roundabouts of malaria. Trends Parasitol. 2003;19(5):209-13.

Beraldo FH, Almeida FM, da Silva AM, Garcia CR. Cyclic AMP and calcium interplay as second messengers in melatonin-dependent regulation of Plasmodium falciparum cell cycle. $\mathbf{J}$ Cell Biol. 2005;170(4):551-7.

Beraldo FH, Garcia CR. Products of tryptophan catabolism induce $\mathrm{Ca}^{2+}$ release and modulate the cell cycle of Plasmodium falciparum malaria parasites. J Pineal Res. 2005; 39(3): 224-30.

Beraldo FH, Mikoshiba K, Garcia CR. Human malarial parasite, Plasmodium falciparum, displays capacitative calcium entry: 2-aminoethyl diphenylborinate blocks the signal transduction pathway of melatonin action on the $P$. falciparum cell cycle. J Pineal Res. 2007;43(4):360-4.

Beraldo FH, Sartorello R, Lanari RD, Garcia CR. Signal transduction in red blood cells of the lizards Ameiva ameiva and Tupinambis merianae (Squamata, Teiidae). Cell Calcium. 2001;29(6):439-45.

Berridge MJ. The versatility and complexity of calcium signalling. Novartis Foundation Symposium 2001;239:52-64; discussion -7, 150-9.

Berridge MJ. Cell Signalling Biology. London: Portland Press; 2012.

Berridge MJ, Bootman MD, Roderick HL. Calcium signalling: dynamics, homeostasis and remodelling. Nature Rev. 2003;4(7):517-29.

Billker O, Dechamps S, Tewari R, Wenig G, Franke-Fayard B, Brinkmann V. Calcium and a calcium-dependent protein kinase regulate gamete formation and mosquito transmission in a malaria parasite. Cell 2004;117(4):503-14.

Blackman MJ, Heidrich HG, Donachie S, McBride JS, Holder AA. A single fragment of a malaria merozoite surface protein remains on the parasite during red cell invasion and is the target of invasion-inhibiting antibodies. J Exp Med. 1990;172(1):379-82.

Boyd GH. Induced variations in the asexual cycle of Plasmodium cathemerium. Am J Trop Med Hyg. 1929; 9:181-7.

Brini M. Calcium-sensitive photoproteins. Methods 2008;46(3):160-6. 
Brini M, Marsault R, Bastianutto C, Alvarez J, Pozzan T Rizzuto R. Transfected aequorin in the measurement of cytosolic $\mathrm{Ca}^{2+}$ concentration $\left(\left[\mathrm{Ca}^{2+}\right] \mathrm{c}\right)$. A critical evaluation. $\mathrm{J}$ Biol Chem. 1995;270(17):9896-903.

Budu A, Garcia CR. Generation of second messengers in Plasmodium. Microbes Infect. 2012. In press.

Budu A, Peres R, Bueno VB, Catalani LH, Garcia CR. N1-acetyl-N2-formyl-5methoxykynuramine modulates the cell cycle of malaria parasites. J Pineal Res. 2007;42(3):2616.

Burnstock G. Purine and pyrimidine receptors. Cell Mol Life Sci. 2007; 64(12):1471-83.

Burnstock G. Purinergic signalling: past, present and future. Braz J Med Biol Res. 2008;42(1):38.

Burnstock G, Verkhratsky A. Evolutionary origins of the purinergic signalling system. Acta Physiol. 2009;195(4):415-47.

By Y, Durand-Gorde JM, Condo J, Lejeune PJ, Mallet B, Carayon P, Guieu R, Ruf J. Production of an agonist-like monoclonal antibody to the human A2A receptor of adenosine for clinical use. Mol Immun. 2009;46(3):400-5.

Callebaut I, Prat K, Meurice E, Mornon JP, Tomavo S. Prediction of the general transcription factors associated with RNA polymerase II in Plasmodium falciparum: conserved features and differences relative to other eukaryotes. BMC Genomics. 2005;6:100.

Carter R, Mendis KN. Evolutionary and historical aspects of the burden of malaria. Clin Microbiol Rev. 2002; 15(4):564-94.

Cerione RA, Strulovici B, Benovic JL, Lefkowitz RJ, Caron MG. Pure beta-adrenergic receptor: the single polypeptide confers cathecolamine responsiveness to adenylate cyclase. Nature. 1983; 306(5943)562-66.

Chang Foreman HC, Van Scoy S, Cheng TF, Reich NC. Activation of interferon regulatory factor 5 by site specific phosphorylation. PloS One. 2012;7(3):e33098.

Cheeseman IM, Desai A. Cell division: AAAtacking the mitotic spindle. Curr Biol. 2004;14(2): R70-2.

Coulson RM, Hall N, Ouzounis CA. Comparative genomics of transcriptional control in the human malaria parasite Plasmodium falciparum. Genome Res. 2004;14(8):1548-54.

Curtidor H, Patino LC, Arevalo-Pinzon G, Patarroyo ME, Patarroyo MA. Identification of the Plasmodium falciparum rhoptry neck protein 5 (PfRON5). Gene 2011;474(1-2):22-8. 
da Cruz LN, Juliano MA, Budu A, Juliano L, Holder AA, Blackman MJ, Garcia CR. Extracellular ATP triggers proteolysis and cytosolic $\mathrm{Ca}^{2+}$ rise in Plasmodium berghei and Plasmodium yoelii malaria parasites. Malar J. 2012;11(1):69.

Daumke O, Lundmark R, Vallis Y, Martens S, Butler PJ, McMahon HT. Architectural and mechanistic insights into an EHD ATPase involved in membrane remodelling. Nature. 2007;449(7164):923-7.

Desai SA, Krogstad DJ, McCleskey EW. A nutrient-permeable channel on the intraerythrocytic malaria parasite. Nature. 1993;362(6421):643-6.

Dluzewski AR, Ling IT, Hopkins JM, Grainger M, Margos G, Mitchell GH, Holder AA, Bannister LH. Formation of the food vacuole in Plasmodium falciparum: a potential role for the $19 \mathrm{kDa}$ fragment of merozoite surface protein 1 (MSP1(19)). PloS One. 2008;3(8):e3085.

Dong C, Filipeanu CM, Duvernay MT, Wu G. Regulation of G protein-coupled receptor export trafficking. Biochem Biophys Acta. 2007;1768(4):853-70.

Dorin-Semblat D, Sicard A, Doerig C, Ranford-Cartwright L, Doerig C. Disruption of the PfPK7 gene impairs schizogony and sporogony in the human malaria parasite Plasmodium falciparum. Eukaryotic Cell. 2008;7(2):279-85.

Doyle SM, Wickner S. Hsp104 and ClpB: protein disaggregating machines. Trends Biochem Sci. 2009;34(1):40-8.

Dunham JH, Hall RA. Enhancement of the surface expression of G protein-coupled receptors. Trends Biotechnol. 2009;27(9):541-5.

Duraisingh MT, Maier AG, Triglia T, Cowman AF. Erythrocyte-binding antigen 175 mediates invasion in Plasmodium falciparum utilizing sialic acid-dependent and -independent pathways. Proc Natl Acad Sci USA. 2003;100(8):4796-801.

Dvorak JA, Miller LH, Whitehouse WC Shiroishi T. Invasion of erythrocytes by malaria merozoites. Science. 1975;187(4178):748-50.

Dyer M, Day K. Expression of Plasmodium falciparum trimeric G proteins and their involvement in switching to sexual development. Mol Biochem Parasitol. 2000;110(2):437-48.

Elies R, Fu LX, Eftekhari P, Wallukat G, Schulze W, Granier C, Hjalmarson A, Hoebeke J. Immunochemical and functional characterization of an agonist-like monoclonal antibody against the M2 acetylcholine receptor. FEBS. 1998;251(3):659-66.

Farias SL, Gazarini ML, Melo RL, Hirata IY, Juliano MA, Juliano L, Garcia CR. Cysteineprotease activity elicited by $\mathrm{Ca}^{2+}$ stimulus in Plasmodium. Mol Biochem Parasitol. 2005;141(1):71-9. 
Fredriksson R, Lagerström MC, Lundin LG, Schiöth HB. The G-protein-copled receptors in the human genome form five main families. Phylogenetic analysis, paralogon groups, and fingerprints. Mol Pharmacol. 2003;63(3):1256-72.

Filtz TM, Li Q, Boyer JL, Nicholas RA, Harden TK. Expression of a cloned P2Y purinergic receptor that couples to phospholipase C. Mol Pharmacol. 1994;46(1):8-14.

Fruth IA, Arrizabalaga, G. Toxoplasma gondii: Induction of egress by the potassium ionophore nigericin. Int J Parasitol. 2007;37:1559-67.

Garcia CR, Ann SE, Tavares ES, Dluzewski AR, Mason WT, Paiva FB. Acidic calcium pools in intraerythrocytic malaria parasites. Eur J Cell Biol. 1998;76(2):133-8.

Garcia CR, Markus RP, Madeira L. Tertian and quartan fevers: temporal regulation in malarial infection. J Biol Rhythms. 2001;16(5):436-43.

Garcia GE, Wirtz RA, Barr JR, Woolfitt A, Rosenberg R. Xanthurenic acid induces gametogenesis in Plasmodium, the malaria parasite. J Biol Chem. 1998;273(20):12003-5.

Gardner MJ, Hall N, Fung E, White O, Berriman M, Hyman RW, Carlton JM, Pain A, Nelson KE, Bowman S, Paulsen IT, James K, Eisen JA, Rutherford K, Salzberg SL, Craig A, Kyes S, Chan MS, Nene V, Shallom SJ, Suh B, Peterson J, Angiuoli S, Pertea M, Allen J, Selengut J, Haft D, Mather MW, Vaidya AB, Martin DM, Fairlamb AH, Fraunholz MJ, Roos DS, Ralph SA, McFadden GI, Cummings LM, Subramanian GM, Mungall C, Venter JC, Carucci DJ, Hoffman SL, Newbold C, Davis RW, Fraser CM, Barrell B. Genome sequence of the human malaria parasite Plasmodium falciparum. Nature. 2002;419(6906):498-511.

Gazarini ML, Garcia CR. The malaria parasite mitochondrion senses cytosolic $\mathrm{Ca}^{2+}$ fluctuations. BBRC. 2004;321(1):138-44.

Gazarini ML, Thomas AP, Pozzan T, Garcia CR. Calcium signaling in a low calcium environment: how the intracellular malaria parasite solves the problem. J Cell Biol. 2003;161(1):103-10.

Goetzl EJ, Dembrow D, Van Brocklyn JR, Graler MHuang MC. An IgM-kappa rat monoclonal antibody specific for the type 1 sphingosine 1-phosphate $G$ protein-coupled receptor with antagonist and agonist activities. Immunol Lett. 2004;93(1):63-9.

Gonzalez-Maeso J. GPCR oligomers in pharmacology and signaling. Mol Brain. 2011;4(1):20.

Grabowsky M. The billion-dollar malaria moment. Nature. 2008;451(7182):1051-2.

Green JL, Rees-Channer RR, Howell SA, Martin SR, Knuepfer E, Taylor HM, Grainger M, Holder AA. The motor complex of Plasmodium falciparum: phosphorylation by a calciumdependent protein kinase. J Biol Bhem. 2008;283(45):30980-9. 
Guinovart C, Navia MM, Tanner M, Alonso PL. Malaria: burden of disease. Curr Mol Med. 2006;6(2):137-40.

Gurevich VV, Gurevich EV. GPCR monomers and oligomers: it takes all kinds. Trends Neurosci. 2008;31(2):74-81.

Harrison T, Samuel BU, Akompong T, Hamm H, Mohandas N, Lomasney JW, Haldar K. Erythrocyte $G$ protein-coupled receptor signaling in malarial infection. Science. 2003;301(5640):1734-6.

Hawking F. The clock of the malaria parasite. Sci Am. 1970;222(6):123-31.

Heidrich HG, Matzner M, Miettinen-Baumann A, Strych W. Immunoelectron microscopy shows that the 80,000-dalton antigen of Plasmodium falciparum merozoites is localized in the surface coat. Z Parasitenkd. 1986;72(5):681-3.

Hislop JN, von Zastrow M. Role of ubiquitination in endocytic trafficking of G-protein-coupled receptors. Traffic. 2011;12(2):137-48.

Holder AA, Blackman MJ, Burghaus PA, Chappel JA, Ling IT, McCallum-Deighton NShai S. A malaria merozoite surface protein (MSP1)-structure, processing and function. Mem Inst Oswaldo Cruz. 1992;87 Suppl 3:37-42.

Hotta CT, Gazarini ML, Beraldo FH, Varotti FP, Lopes C, Markus RP, Pozzan T, Garcia CR. Calcium-dependent modulation by melatonin of the circadian rhythm in malarial parasites. Nature Cell Biol. 2000;2(7):466-8.

Kauth CW, Woehlbier U, Kern M, Mekonnen Z, Lutz R, Mucke N, Langowski J, Bujard H. Interactions between merozoite surface proteins 1, 6, and 7 of the malaria parasite Plasmodium falciparum. J Biol Chem. 2006;281(42):31517-27.

Kolakowski Jr LF. GCRDb: a G-protein-coupled receptor database. Rec Chann. 1994;2(1):1-7.

Koyama FC, Ribeiro RY, Garcia JL, Azevedo MF, Chakrabarti D, Garcia CR. Ubiquitin proteasome system and the atypical kinase PfPK7 are involved in melatonin signaling in Plasmodium falciparum. J Pineal Res. 2012. In press.

Kumar KA, Garcia CR, Chandran VR, Van Rooijen N, Zhou Y, Winzeler E, Nussenzweig V. Exposure of Plasmodium sporozoites to the intracellular concentration of potassium enhances infectivity and reduces cell passage activity. Mol Biochem Parasitol. 2007;156(1):32-40.

Kuner T, Li Y, Gee KR, Bonewald LF, Augustine GJ. Photolysis of a caged peptide reveals rapid action of N-ethylmaleimide sensitive factor before neurotransmitter release. Proc Natl Acad Sci USA. 2008;105(1):347-52.

Kutner S, Ginsburg H, Cabantchik ZI. Permselectivity changes in malaria (Plasmodium falciparum) infected human red blood cell membranes. J Cell Physiol. 1983;114(2):245-51. 
Lagerström MC, Schiöth HB. Structural diversity of G-protein-coupled receptors and significance for drug discovery. Nat Rev Drug Discovery. 2008;7(4)339-57.

Lambros C, Vanderberg JP. Synchronization of Plasmodium falciparum erythrocytic stages in culture. J Parasitol. 1979;65(3):418-20.

Lauterbach SB, Coetzer TL. The M18 aspartyl aminopeptidase of Plasmodium falciparum binds to human erythrocyte spectrin in vitro. Malar J. 2008;7:161.

Lebesgue D, Wallukat G, Mijares A, Granier C, Argibay J, Hoebeke J. An agonist-like monoclonal antibody against the human beta2-adrenoceptor. Eur J of Pharm. 1998;348(1):12333.

Lefkowitz RJ, Rajagopal K, Wahlen EJ. New roles for beta-arestins in cell signaling: not just for seven-transmembrane receptors. Mol Cell. 2006;24(5):643-52

Lefkowitz RJ. Seven transmembrane receptors: something old, something new. Acta Physiol. 2007;190(1):9-19.

Levano-Garcia J, Dluzewski AR, Markus RP, Garcia CR. Purinergic signalling is involved in the malaria parasite Plasmodium falciparum invasion to red blood cells. Purinergic Signal. 2010;6(4):365-72.

Liu QH, Zheng YM, Korde AS, Yadav VR, Rathore R, Wess JWang YX. Membrane depolarization causes a direct activation of $\mathrm{G}$ protein-coupled receptors leading to local $\mathrm{Ca}^{2+}$ release in smooth muscle. Proc Natl Acad Sci USA. 2009;106(27):11418-23.

Madeira L, Galante PA, Budu A, Azevedo MF, Malnic B, Garcia CR. Genome-wide detection of serpentine receptor-like proteins in malaria parasites. PloS One. 2008;3(3):e1889.

Magno AL, Ward BK, Ratajczak T. The calcium-sensing receptor: a molecular perspective. Endocr Rev. 2011;32(1):3-30.

Marchese A, Paing MM, Temple BRS, Trejo J. G protein-coupled receptor sorting to andosomes and lysosomes. Annu Rev Pharmacol Toxicol. 2008;48:601-29.

Mauritz JM, Esposito A, Tiffert T, Skepper JN, Warley A, Yoon YZ, Cicuta P, Lew VL, Guck JR, Kaminski CF. Biophotonic techniques for the study of malaria-infected red blood cells. Med Biol Eng Comput. 2010;48(10):1055-63.

Meissner M, Schluter D, Soldati D. Role of Toxoplasma gondii myosin A in powering parasite gliding and host cell invasion. Science. 2002;298(5594):837-40.

Millar RP, Nweton CL. The year in G protein-coupled receptor research. Mol Endocrinol. 2010;24(1):261-74. 
Moore CA, Milano SK, Benovic JL. Regulation of receptor trafficking by GRKs and arrestins. Ann Rev Physiol. 2007;69:451-82.

Moss DK, Remarque EJ, Faber BW, Cavanagh DR, Arnot DE, Thomas AW, Holder AA. Plasmodium falciparum 19-kilodalton merozoite surface protein 1 (MSP1)-specific antibodies that interfere with parasite growth in vitro can inhibit MSP1 processing, merozoite invasion, and intracellular parasite development. Infect Immun. 2012;80(3):1280-7.

Mota MM, Pradel G, Vanderberg JP, Hafalla JC, Frevert U, Nussenzweig RS, Nussenzweig V, Rodriguez A. Migration of Plasmodium sporozoites through cells before infection. Science. 2001;291(5501):141-4.

Moudy R, Manning TJ, Beckers CJ. The loss of cytoplasmic potassium upon host cell breakdown triggers egress of Toxoplasma gondii. J Biol Chem. 2001;276(44):41492-501.

Murphy SC, Fernandez-Pol S, Chung PH, Prasanna Murthy SN, Milne SB, Salomao M, Brown HA, Lomasney JW, Mohandas N Haldar K. Cytoplasmic remodeling of erythrocyte raft lipids during infection by the human malaria parasite Plasmodium falciparum. Blood. 2007;110(6):2132-9.

Neuhaus EM, Mashukova A, Zhang W, Barbour J, Hatt H. A specific heat shock protein enhances expression of mammalian olfactory receptor proteins. Chem Senses. 2006;31(5):445452 .

Offermanns S, Simon MI. G alpha 15 and G alpha 16 couple a wide variety of receptors to phospholipase C. J Biol Chem. 1995;270(25):15175-80.

Olkkonen VM, Stenmark H. Role of Rab GTPases in membrane traffic. Int Rev Cyt. 1997;176:185 .

Ono T, Cabrita-Santos L, Leitao R, Bettiol E, Purcell LA, Diaz-Pulido O, Andrews LB, Tadakuma T, Bhanot P, Mota MM, Rodriguez A. Adenylyl cyclase alpha and cAMP signaling mediate Plasmodium sporozoite apical regulated exocytosis and hepatocyte infection. Plos Path. 2008;4(2):e1000008.

Ovchinnikov YA. Structure of rhodopsin and bacteriorhodopsin. Photochem Photobiol. 1987;45(6):909-14.

Pang XL, Mitamura THorii T. Antibodies reactive with the $\mathrm{N}$-terminal domain of Plasmodium falciparum serine repeat antigen inhibit cell proliferation by agglutinating merozoites and schizonts. Infect Immun. 1999;67(4):1821-7.

Pei X, Guo X, Coppel R, Bhattacharjee S, Haldar K, Gratzer W, Mohandas N, An X. The ringinfected erythrocyte surface antigen (RESA) of Plasmodium falciparum stabilizes spectrin tetramers and suppresses further invasion. Blood 2007;110(3):1036-42. 
Petersen I, Eastman R, Lanzer M. Drug-resistant malaria: molecular mechanisms and implications for public health. FEBS Lett. 2011;585(11):1551-62.

Ramachandran R. Vesicle scission: dynamin. Semin Cell Dev Biol. 2011;22(1):10-7.

Rapoport TA. Transport of proteins across the endoplasmic reticulum membrane. Science. 1992;258(5084):931-6.

Rug M, Prescott SW, Fernandez KM, Cooke BM, Cowman AF. The role of KAHRP domains in knob formation and cytoadherence of $P$ falciparum-infected human erythrocytes. Blood. 2006; 108(1):370-8.

Scheuer T. Regulation of sodium channel activity by phosphorylation. Semin Cell Dev Biol. 2011;22(2):160-5.

Schuck DC, Ribeiro RY, Nery AA, Ulrich H, Garcia CR. Flow cytometry as a tool for analyzing changes in Plasmodium falciparum cell cycle following treatment with indol compounds. Cyt A. 79(11):959-64.

Seger R, Krebs EG. The MAPK signaling cascade. Faseb J. 1995;9(9):726-35.

Selbie LA, Hill SJ. G protein-coupled receptor cross talk: the fine tuning of multiple receptorsignalling pathways. Trends Pharmacol Sci. 1998;19(3):87-93.

Shenoy SK, Drake MT, Nelson CD, Houtz DA, Xiao K, Madabushi S, Reiter E, Premont RT, Lichtarge O, Lefkowitz RJ. Beta-arrestin-dependent, G protein-independent ERK1/2 activation by the beta2 adrenergic receptor J Biol Chem. 2006;281(2):1261-73.

Singh S, Alam MM, Pal-Bhowmick I, Brzostowski JA, Chitnis CE. Distinct external signals trigger sequential release of apical organelles during erythrocyte invasion by malaria parasites. PLoS Path. 2010;6(2):e1000746.

Snow RW, Guerra CA, Noor AM, Myint HY, Hay SI. The global distribution of clinical episodes of Plasmodium falciparum malaria. Nature. 2005;434(7030):214-7.

Staines HM, Ellory JC, Kirk K. Perturbation of the pump-leak balance for $\mathrm{Na}^{+}$and $\mathrm{K}^{+}$in malariainfected erythrocytes. Am J Physiol Cell Physiol. 2001;280(6):C1576-87.

Sturm A, Amino R, van de Sand C, Regen T, Retzlaff S, Rennenberg A, Krueger A, Pollok JM, Menard R, Heussler VT. Manipulation of host hepatocytes by the malaria parasite for delivery into liver sinusoids. Science. 2006;313(5791):1287-90.

Taipale M, Jarosz DF, Lindquist S. HSP90 at the hub of protein homeostasis: emerging mechanistic insights. Nature Reviews 2010;11(7):515-28.

Tan CM, Brady AE, Nickols HH, Wang Q, Limbird LE. Membrane trafficking of G-protein coupled receptors.Ann Rev Pharmacol Toxicol. 2004;44:559-609. 
Tan CS. Sequence, structure, and network evolution of protein phosphorylation. Sci Signal. 2011; 4(182):mr6.

Tan DX, Manchester LC, Terron MP, Flores LJ, Reiter RJ. One molecule, many derivatives: a never-ending interaction of melatonin with reactive oxygen and nitrogen species? J Pineal Res. 2007;42(1):28-42.

Tang BL, Zhang T, Low DY, Wong ET, Horstmann H, Hong W. Mammalian homologues of yeast sec31p. An ubiquitously expressed form is localized to endoplasmic reticulum (ER) exit sites and is essential for ER-Golgi transport. J Biol Chem. 2000;275(18):13597-604.

Tonkin CJ, van Dooren GG, Spurck TP, Struck NS, Good RT, Handman E, Cowman AF, McFadden GI. Localization of organellar proteins in Plasmodium falciparum using a novel set of transfection vectors and a new immunofluorescence fixation method. Mol Biochem Parasitol. 2004;137(1):13-21.

Trager W, Jensen JB. Human malaria parasites in continuous culture. Science. 1976;193(4254):673-5.

Trouiller P, Olliaro P, Torreele E, Orbinski J, Laing R, Ford N. Drug development for neglected diseases: a deficient market and a public-health policy failure. Lancet 2002;359(9324):2188-94.

Ullrich O, Stenmark H, Alexandrov K, Huber LA, Kaibuchi K, Sasaki T, Takai Y Zerial M. Rab GDP dissociation inhibitor as a general regulator for the membrane association of rab proteins. J Biol Chem. 1993;268(24):18143-50.

Varotti FP, Beraldo FH, Gazarini ML, Garcia CR. Plasmodium falciparum malaria parasites display a THG-sensitive Ca2+ pool. Cell Calcium. 2003;33(2):137-44.

Vauquelin G, Van Liefde I. G protein-coupled receptors: a count of 1001 conformations. Fundam Clin Pharmacol. 2005;19(1):45-56.

Volonte C, Amadio S, D'Ambrosi N, Colpi M, Burnstock G. P2 receptor web: complexity and fine-tuning. Pharmacol Therapeutics. 2006;112(1):264-80.

Wan J, Ristenpart WD, Stone HA. Dynamics of shear-induced ATP release from red blood cells. Proc Natl Acad Sci USA. 2008;105(43): 16432-7.

Wang Q, Song C, Li CC. Molecular perspectives on p97-VCP: progress in understanding its structure and diverse biological functions. J Struct Biol. 2004;146(1-2):44-57.

Whiteheart SW, Hart GW. Incorporation of [3H]ethanolamine into a single cytosolic protein in a cell free system: ethanolaminylation of EF-1 alpha in vitro. Arch Biochem Biophys. 1994;309(2):387-91. 
Wicher D, Schafer R, Bauernfeind R, Stensmyr MC, Heller R, Heinemann SH, Hansson BS. Drosophila odorant receptors are both ligand-gated and cyclic-nucleotide-activated cation channels. Nature. 2008;452(7190):1007-11.

Woehlbier U, Epp C, Hackett F, Blackman MJ, Bujard H. Antibodies against multiple merozoite surface antigens of the human malaria parasite Plasmodium falciparum inhibit parasite maturation and red blood cell invasion. Malar J. 2010;9:77.

Worrall E, Basu S, Hanson K. Is malaria a disease of poverty? A review of the literature. Trop Med Int Health. 2005;10(10):1047-59. 


\section{ANEXO A- Artigos publicados no período do doutorado}

Madeira L, Galante PAF, Budu A, Azevedo MF, Malnic B, Garcia CRS. Genome-wide detection of serpentine receptor-like proteins in malaria parasites. PloS One 2008;3(3):e1889.

Garcia CRS, Azevedo MF, Wunderlich G, Budu A, Young JA, Bannister L. Plasmodium in the Postgenomic Era: New Insights into the Molecular Cell Biology of Malaria Parasites. Int Rev Cell Mol Biol. 2008;266:85-156.

Sartorello R, Budu A, Bagnaresi P, Fernandes CA, Sato PM, Bueno VB, Fontes MRM, Oliveria PL, Paiva-Silva GO, Alves SV, Netto LES, Catalani LH, Garcia CRS. In vivo uptake of a haem analogue $\mathrm{Zn}$ protoporphyrin IX by the human malaria parasite $P$. falciparuminfected red blood cells. Cell Biol Int. 2010;34:859-65.

Cruz LN, Juliano MA, Budu A, Juliano L, Holder AA, Blackman MJ, Garcia CRS. Extracellular ATP triggers proteolysis and cytosolic $\mathrm{Ca}^{2+}$ rise in Plasmodium berghei and Plasmodium yoelii malaria parasites. Malar J. 2012;11(1):69.

Generation of second messengers in Plasmodium. Budu A, Garcia CRS. Microb Inf. 2012;14:787-95. 